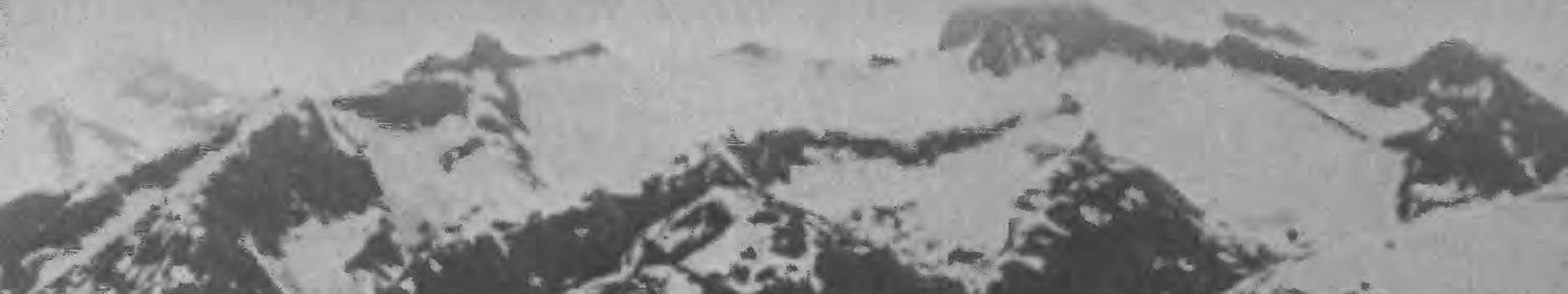

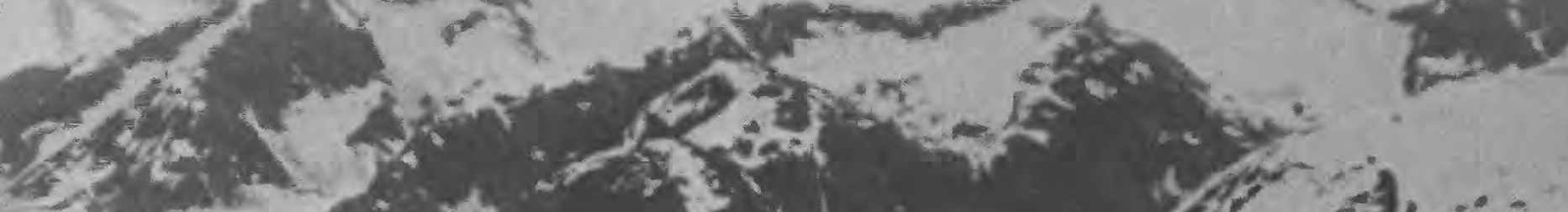

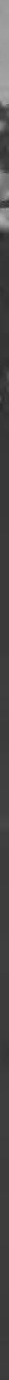




\section{Cover photograph}

South Sawyer Glacier in southeastern Alaska. View southeast from head of Tracy Arm. 


\section{The United States Geological Survey in Alaska: Accomplishments during 1977}

Kathleen M. Johnson, Editor

GEOLOGICAL SURVEY CIRCULAR 772-B 


\section{United States Department of the Interior}

\section{CECIL D. ANDRUS, Secretary}

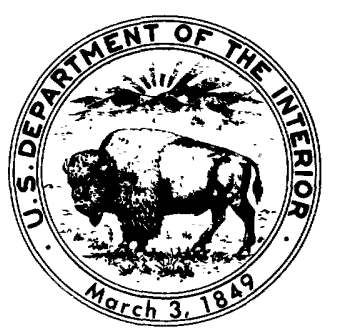

\section{Geological Survey}

H. William Menard, Director 


\section{CONTENTS}

B1

Summary of important results

Introduction

Statewide projects _

Mineral resources of Alaska, by Edward $\mathbf{H}$.

Cobb

Landsat color mosaic of Alaska, by Nairn R. D. Albert, Wm. Clinton Steele, and James R. LeCompte - - - - - - - -

Landsat data interpretation of various AMRAP quadrangles, Alaska by Nairn R. D. Albert, Wm. Clinton Steele and James R.

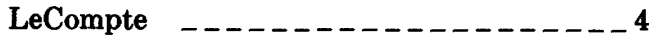

Geochemical exploration studies in Alaska, by G. C. Curtin, T. D. Hessin, R. M. O'Leary, E. F. Cooley, G. W. Day, and R. B. Tripp

Streamflow and channel erosion investigations along the TAPS route, by J. M. Childers, D. Kernodle, and R. Loeffler

Regional appraisal of Alaska's ground-water resources, by Chester Zenone and G. S. Anderson - - - --------------7

Northern Alaska

The Arrigetch Peaks and Mount Igikpak plutons, Survey Pass quadrangle, Alaska, by $\mathrm{S}$. W. Nelson and Donald Grybeck _ _ _

Potential strata-bound lead-zinc mineralization, Philip Smith Mountains quadrangle, Alaska, by J. T. Dutro, Jr _ _

Granitic clasts from Lower Cretaceous conglomerate in the northwestern Brooks Range, by C. F. Mayfield, I. L. Tailleur, C. G. Mull, and M. L. Silberman

Cretaceous Nanushuk Group, North Slope, Alaska, by Thomas S. Ahlbrandt and A. Curtis Huffman

Geologic investigations of metallic mineral resources of southern NPRA, by Michael Churkin, Jr., Carl Huie, C. F. Mayfield, and Warren J. Nokleberg _-

Stratiform zinc-lead mineralization, Drenchwater Creek area, Howard Pass quadrangle, western Brooks Range, Alaska, by Warren J. Nokleberg and Gary R. Winkler _ _ _ _ 17

Surficial geology of the foothills and mountains of NPRA, by Warren Yeend _ _ _ -19

Coastal plain deposits of NPRA, by John R. Williams, L. David Carter, and Warren E. Yeend

Studies of proposed airfields at the Inigok and Tunalik well sites, NPRA, by Reuben $\mathrm{Ka}$ chadoorian, F. E. Crory, and D. L. Berg --22

Granite on the Barrow arch, northeast NPRA, by K. J. Bird, C. L. Connor, I. L. Tailleur, M. L. Silberman, and J. L. Christie $-24$
Northern Alaska-Continued

Page

Organic geochemistry of rocks from three NPRA wells, by Leslie B. Magoon and George E. Claypool $\ldots \ldots---\ldots-\ldots \ldots$ B25

Release of NPRA (NPR-4) data, by Robert D. Carter _.

Fossil reconnaissance study, eastern NPRA, by Charles A. Repenning _ _ _

Reconnaissance snow survey of NPRA, April 1977, by Charles E. Sloan, Dennis Trabant, and William Glude

Hydrologic reconnaissance of lakes in NPRA, 1977, by Charles E. Sloan and Richard F. Snyder _-

Streamflow in NPRA, 1977, by S. H. Jones --29

Development and operation of gas fields in the South Barrow area, by Robert D. Carter and Robert J. Lantz _ _- _

A simple target model for offshore permafrost at Prudhoe Bay, by Arthur H. Lachenbruch and B. Vaughn Marshall

Geophysical profiles through the ShaviovikEchooka River region, by Dennis Giovannetti and $K$. J. Bird _ ----------32

Hydrology of arctic Alaska, by J. M. Childers, D. Kernodle, and R. Loeffler _

East-central Alaska _.__

Late Paleozoic radiolarians and conodonts found in chert of Big Delta quadrangle, by H. L. Foster, D. L. Jones, T. E. C. Keith, Bruce Wardlaw, and F. R. Weber _ _ _ _ 34

Late Cenozoic stratigraphy of the south-central Brooks Range, by Thomas D. Hamilton _ 36

Geohydrology of the Fairbanks-North Star Borough, by G. L. Nelson

Geohydrology of the Delta-Clearwater area, by G. L. Nelson

West-central Alaska _

Juxtaposed continental and oceanic-island arc terranes in the Medfra quadrangle, westcentral Alaska, by William W. Patton, Jr _ 38

Preliminary summary of the geology in the northwest part of the Ruby quadrangle, by Robert M. Chapman and William W. Patton, Jr _ -

Landslides near Melozitna River canyon, by Robert M. Chapman and William W. Patton, Jr _

An occurrence of parsonite, a secondary uranium mineral, in alaskite of the Wheeler Creek pluton, by Thomas P. Miller and Bruce R. Johnson $-42$ 
West-central Alaska-Continued

Tin-granites of Seward Peninsula, by Travis Hudson, Fred Barker, and Joseph Arth _ _ B44

Upper Triassic radiolarian chert from the Kobuk volcanic sequence in the southern Brooks Range, by George Plafker, Travis Hudson, and D. L. Jones _-

Kigluaik and Bendeleben faults, Seward Peninsula, by Travis Hudson and George Plafker

Preliminary investigations of coal outcrops near Farewell, Alaska, by Ernest G. Sloan, Gerald B. Shearer, James Eason, and Carl Almquist

Southwestern Alaska

New geologic map of the Goodnews-Hagemeister Island quadrangles region, Alaska, by J. M. Hoare and W. L. Coonrad

Lawsonite in southwest Alaska, by J. M. Hoare and W. L. Coonrad $-55$

Upper Jurassic and Cretaceous rocks of the Kamishak Hills-Douglas River area, lower Cook Inlet, by Leslie B. Magoon, Robert M. Egbert, and George Petering ___ _ _ _ 57

Petrography of the Upper Jurassic through Oligocene sandstones in the Cape DouglasKamishak Hills area, lower Cook Inlet, by Stephen M. Lankford and Leslie B. Magoon _ 60

Interpretation of depositional environments in the Chignik Formation, Alaska Peninsula, by Robert L. Detterman

New ages on intrusive rocks and altered zones on the Alaska Peninsula, by F. H. Wilson, R. L. Detterman, and M. L. Silberman _ _ _ 63

Tertiary sedimentary rocks of the Alaska Peninsula between Pavlof Bay and False Pass; their geology and petroleum potential, by Hugh McLean

Southern Alaska

New potassium-argon data on the age of mineralization and metamorphism in the Willow Creek mining district, southern Talkeetna Mountains, Alaska, by Miles L. Silberman, Béla Csejtey, Jr., James G. Smith, Marvin A. Lanphere, and Frederick H. Wilson

Tectonic significance of newly discovered lower Paleozoic strata in the upper Chulitna Valley, south-central Alaska, by Béla Csejtey, Jr., Willis H. Nelson, David L. Jones, and Norman J. Silberling _ _ _ _ _ _ _ 69

Framework grain mineralogy and provenance of sandstone from the Arkose Ridge and Chickaloon Formations, Matanuska Valley, by Gary R. Winkler _ _ _ _ _ _

Generalized physiography and geology of the Beluga coal field and vicinity, south-central Alaska, by Henry R. Schmoll and Lynn A. Yehle $-73$
Southern Alaska-Continued

Analysis of remotely sensed data for use in evaluating onshore impacts of offshore petroleum development at Kenai, Alaska, by Harry F. Lins, Jr _ _

Application of remotely sensed data for ground-water analysis near Denali, Alaska, by James K. Richard

Computer enhancement of Landsat digital data for mapping material-related geomorphic features near Denali, Alaska, by Cynthia A. Sheean _-

Classification of vegetation in the Denali, Alaska area with digital Landsat data, by Wayne G. Rohde, Wayne A. Miller, and Charles A. Nelson _ _ _ _

Water resources studies in the Anchorage area, by Chester Zenone

Southeastern Alaska _

New geologic map of Ketchikan and Prince Rupert quadrangles, southeastern Alaska, by Henry C. Berg, Raymond L. Elliott, James G. Smith, and Richard D. Koch _ _ 82

Chemistry of Quartz Hill intrusive rocks, Ketchikan quadrangle, by Travis Hudson, Raymond L. Elliott, and James G. Smith _ _ _ 83

Minor-metal content of Cretaceous greenstone near Juneau, Alaska, by Arthur B. Ford and David A. Brew _ _ _ _

Intrusive rocks in the Fairweather Range, Glacier Bay National Monument, Alaska, by David A. Brew, Bruce R. Johnson, Arthur B. Ford, and Robert P. Morrell _ _ _ _ _ 88

Tarr Inlet suture zone, Glacier Bay National Monument, by David A. Brew and Robert P.

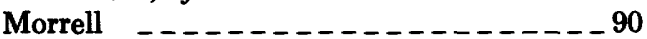

Offshore Alaska _

Heat flow and organic gas measurements from the Aleutian Basin, Bering Sea, by Alan K. Cooper $-92$

Environmental geologic studies in northern Bering Sea, by Devin R. Thor and Hans Nelson -- - -

Navarin basin, northwest Bering Sea shelf, by Mike Marlow _ _ _

Seismicity near Icy Bay, Alaska and in the eastern Gulf of Alaska, by Christopher Stephens _._.

Outcrop samples from the Continental Slope in the eastern Gulf of Alaska, by George Plafker, Gary R. Winkler, Susan J. Hunt, Susan Bartsch-Winkler, Warren L. Coonrad, and Paula Quinterno

Reports on Alaska published by the U.S. Geological Survey in 1977

Revisions to 1:1,000,000-scale map of Alaska _ - 110

Introduction _.

Goodnews-Hagemeister Island quadrangles region, by J. M. Hoare and W. L. Coonrad _ 112

Ketchikan and Prince Rupert quadrangles, by Henry C. Berg, Raymond L. Elliott, James G. Smith, and Richard D. Koch 114 


\section{ILLUSTRATIONS}

FIGURE 1. Map showing regions of Alaska used in this report

2. Location map, studies discussed in summary of important results

3. Photograph of surface of coarse-grained gneiss from the Arrigetch Peaks pluton

4. Generalized stratigraphic section, unnamed Upper Devonian formation and Hunt Fork Shale $\ldots$

5. Location map, sampled conglomerate, and potential igneous source areas, northwestern Brooks Range - 12

6. Generalized stratigraphic sequence, Cretaceous Nanushuk Group

7. Location map, mineral resource assessment studies, southern NPRA _ _ _ _

8. Schematic section across Brooks Range and North Slope

9. Generalized columnar section, lowest structural sequence, southern NPRA

10. Geologic map, Drenchwater thrust plate

11. Map of surficial deposits, Arctic coastal plain, NPRA

12. Map of NPRA showing locations of Inigok and Tunalik well sites

13. Lithology and wireline log response of granite in East Teshekpuk No. 1

14. Photograph showing snow density sampling, NPRA

15. Schematic representation of sub-sea temperatures following submergence of a region underlain by ice-rich permafrost

16. Gravity and magnetic profiles across northeastern Brooks Range front

17. Photograph showing water quality sampling at Bogie Creek

18. Geologic map, northeastern Big Delta quadrangle

19. Sketch map, selected bluff exposures, Koyukuk and Chandalar drainage basins

20. Map of Medfra quadrangle, showing Nixon Fork and Innoko terranes

21. Preliminary geologic map of northwest part of Ruby quadrangle

22. Photograph of headward portion of a large landslide north of Melozitna River canyon

23. Generalized geologic map, western Purcell Mountains _

24. Location map, Seward Peninsula tin-granites

25. Location map, Upper Triassic radiolarian chert localities and Carboniferous megafossils within Kobuk ophiolite belt _

26. Photomicrograph of Pseudoheliodiscus sp

27. Location map, Kigluaik and Benedeleben faults, Seward Peninsula

28. Generalized geologic map, Goodnews and Hagemeister Island quadrangles

29. Description of map units, Goodnews and Hagemeister Island quadrangles _

30. Geologic sketch map, lawsonite and blue amphibole localities and possible suture zone, southwestern Alaska _.

31. Geologic map, Kamishak Hills-Douglas River area

32. Q-F-L diagrams, Upper Jurassic through Oligocene sandstones, Cape Douglas-Kamishak Hills area

33. Location map, potassium argon studies in Chignik and Sutwik Islands quadrangles

34. Geologic map of Alaska Peninsula between Pavlof Bay and False Pass _

35. Geologic map, Willow Creek area, southern Talkeetna Mountains _ _ _ _ _ _

36. Generalized geologic map upper Chulitna Valley area, south-central Alaska

37. Framework grain compositions of 28 point-counted sandstones from the Matanuska Valley

38. Preliminary map showing generalized physiography and geology of the Beluga coal field and vicinity -

39. Urban and developing land, Kenai test site

40. Generalized geologic map, Ketchikan and Prince Rupert quadrangles

41. Plot of normative $Q-O r-A b+A n$ ratios, Quartz Hill intrusive rocks, Ketchikan quadrangle

42. Sketch map, western Glacier Bay National Monument

43. Bathymetric map, Aleutian Basin, Bering Sea

44. Map showing potentially hazardous regions, northern Bering Sea

45. Map showing epicenters and first-motion plots of earthquakes beneath Icy Bay between September 1974 and September 1976

46. Map showing locations of outcrop dredge samples, eastern Gulf of Alaska

47. Generalized geologic map, Goodnews and Hagemeister Island quadrangles

48. Generalized geologic map, Ketchikan and Prince Rupert quadrangles

\section{TABLES}

TABLE 1. Stratigraphic succession, Koyukuk and Chandalar drainage systems, south-central Brooks Range
2. Delayed neutron determinations of uranium and thorium in selected grab samples, Wheeler Creek pluton

3. Potassium-argon ages of granitic rocks, schist, and mineralization, southern Talkeetna Mountains - -

4. Average minor-metal content of metavolcanic rocks near Juneau

5. Summary of data for outcrop samples recovered in dredge hauls, eastern Gulf of Alaska 


\title{
The United States Geological Survey in Alaska Accomplishments during 1977
}

\author{
Kathleen M. Johnson, Editor
}

\begin{abstract}
United States Geological Survey projects in Alaska study a wide range of topics of economic and scientific interest. Work done in 1977 includes contributions to economic geology, regional geology, stratigraphy, environmental geology, engineering geology, hydrology, and marine geology. Many maps and reports covering various aspects of the geology and mineral and water resources of the State were published. In addition, the published 1:1,000,000-scale map of the State has been revised in two areas.
\end{abstract}

\section{SUMMARY OF IMPORTANT RESULTS}

\section{INTRODUCTION}

Significant new scientific and economic geologic information has resulted from many topical and field investigations of the Geological Survey in Alaska during the past year. Discussions of the findings or, in some instances, narratives of the course of the investigations are grouped in eight subdivisions corresponding to the six major onshore geographic regions (fig. 1), the offshore projects, and projects that are statewide in scope. Locations of the study areas are shown in figure 2.

\section{STATEWIDE PROJECTS}

\section{Mineral resources of Alaska} By Edward H. Cobb

Products of this office project during 1977 included an open-filed map showing the distribution of mineral deposits (other than organic fuels and construction materials) in Alaska (scale 1:2,500,000) (Cobb and others, 1977); open-filed summaries of references to mineral occurrences (other than organic fuels and construction materials) in five quadrangles (scale 1:250,000) in Alaska (Cobb, 1977b, 1977c; Hoare and Cobb,
1977); and an open-filed list of recent Federal and State reports on the geology and mineral resources of Alaska, indexed by quadrangle (Cobb, 1977a). Current bibliographic and mineral-resource reference materials were made available to the Alaskan Branch information processing project for entry into computerized storage and retrieval banks.

\section{REFERENGES CITED}

Cobb, E. H., 1977a, Selected Geological Survey, U.S. Bureau of Mines, and Alaska Division of Geological and Geophysical Surveys reports and maps on Alaska released during 1976, indexed by quadrangle: U.S. Geol. Survey Open-File Report 77-177, 115 p.

1977b, Summary of references to mineral occurrences (other than mineral fuels and construction materials) in the Tanana quadrangle, Alaska: U.S. Geol. Survey Open-File Report 77-432, $110 \mathrm{p}$.

$1977 \mathrm{c}$, Summary of references to mineral occurrences (other than mineral fuels and construction materials) in the Eagle quadrangle, Alaska: U.S. Geol. Survey OpenFile Report 77-845, 122 p.

Cobb, E. H., Dusel-Bacon, Cynthia, MacKevett, E. M., Jr., and Berg, H. C., 1977, Map showing distribution of mineral deposits (other than organic fuels and construction materials) in Alaska: U.S. Geol. Survey Open-File Report 77-496, 45 p., 1 map, scale 1:2,500,000.

Hoare, J. M., and Cobb, E. H., 1977, Mineral occurrences (other than mineral fuels and construction materials) in the Bethel, Goodnews, and Russian Mission quadrangles, Alaska: U.S. Geol. Survey Open-File Report 77. $156,98 \mathrm{p}$.

Landsat color mosaic of Alaska

By Nairn R. D. Albert, Wm. Clinton Steele, and James R. LeCompte

A controlled 1:1,000,000-scale Landsat falsecolor mosaic of Alaska is now available. The five sheets of the mosaic cover all of Alaska except for southeastern Alaska, which will be available in the near future, Saint Lawrence Island, the Aleu- 


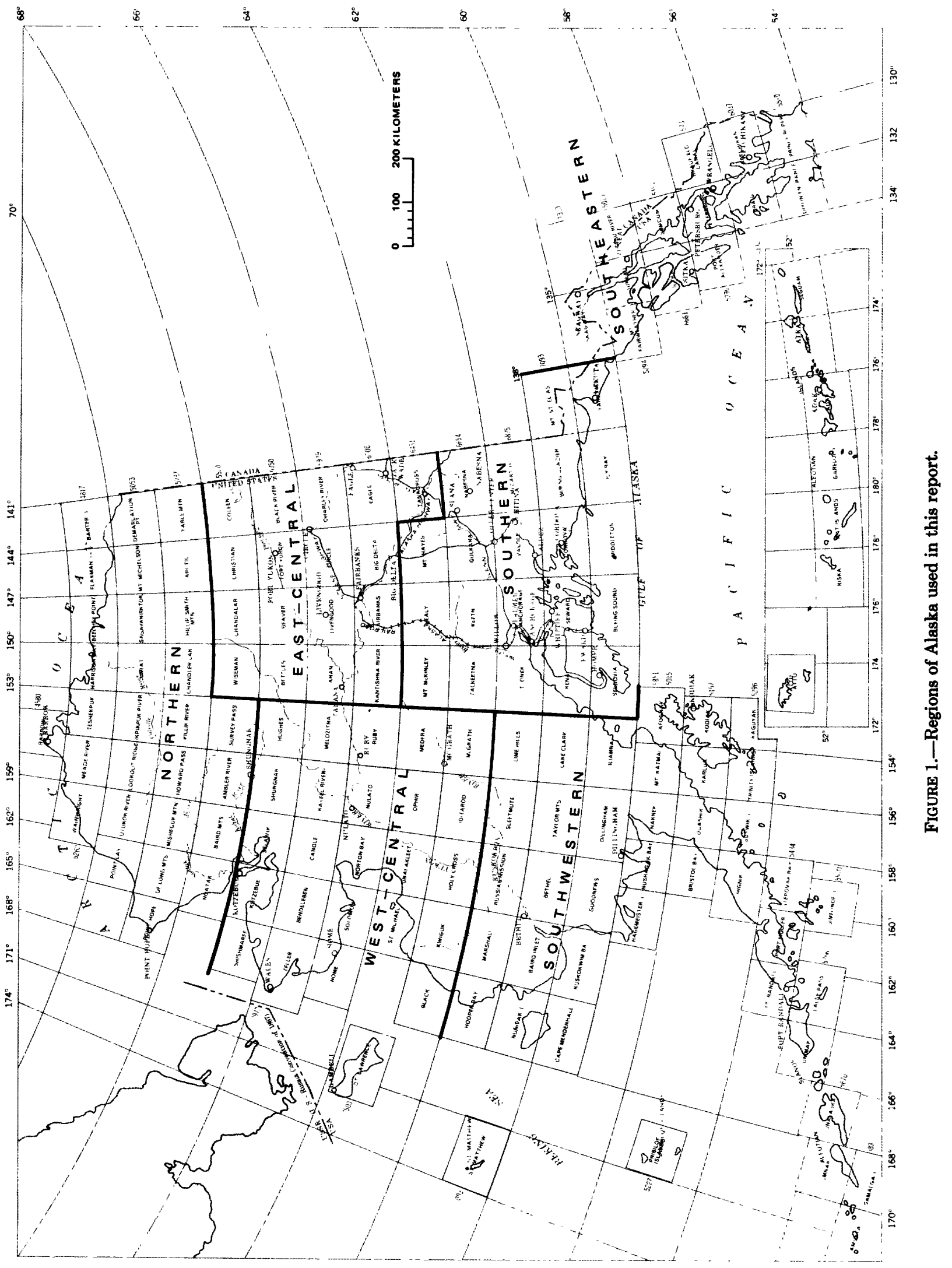




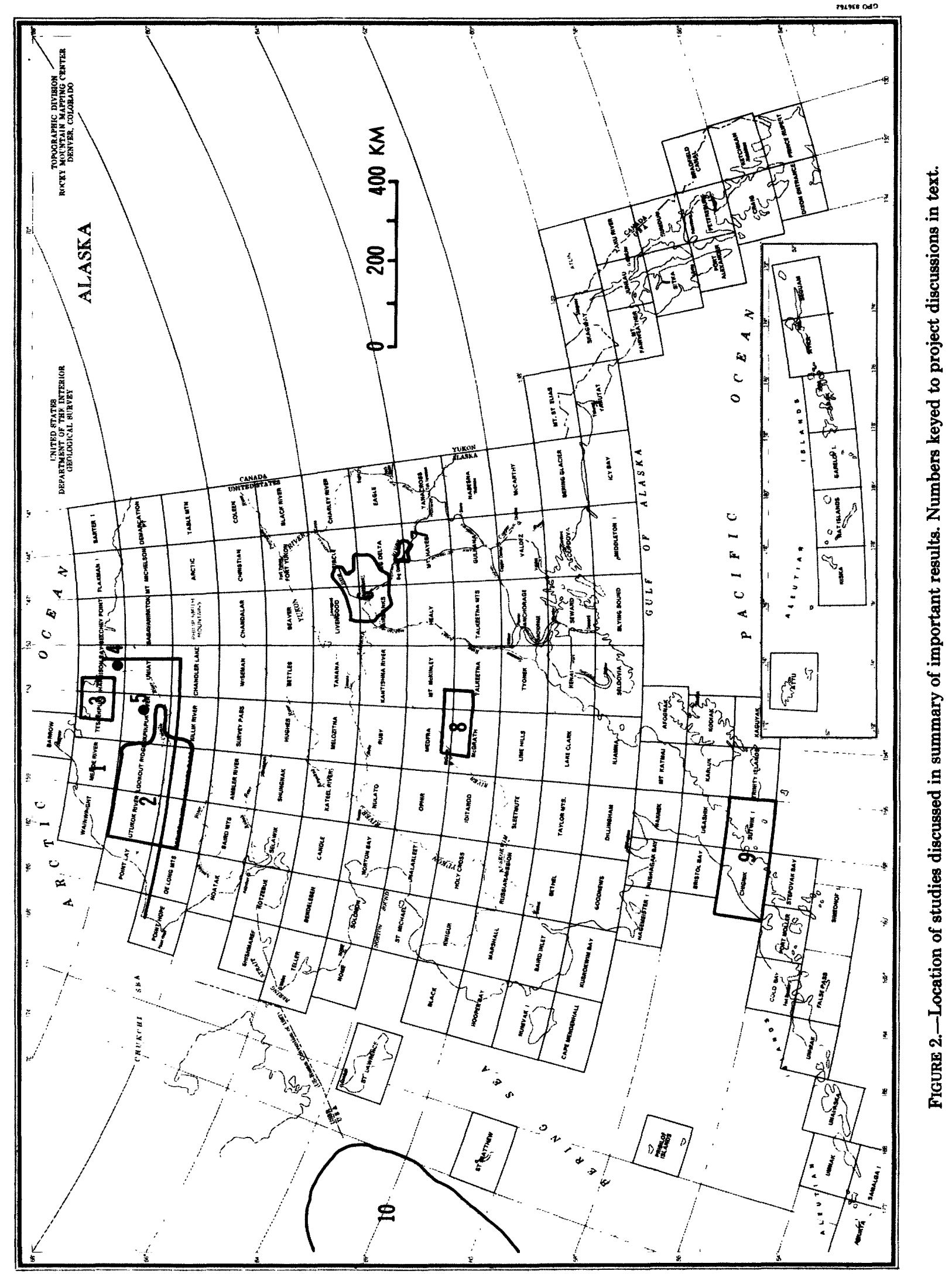


tian Islands, and several other small islands. The mosaic is on a Lambert conformal projection with control established by Topographic Division, Photogrammetry Branch. All scenes were printed on Cibachrome by a commercial scientific photographic laboratory. Although the scenes were taken at different times of the year (spring through fall) and colors vary considerably, we attempted to match colors photographically between scenes as much as possible. Details on coverage, cost, and ordering each of the five sheets can be obtained from the EROS Data Center, Sioux Falls, South Dakota.

Landsat data interpretation of various AMRAP quadrangles, Alaska

By Nairn R. D. Albert, Wm. Clinton Steele, and James R. LeCompte

The use of Landsat imagery in the Chandalar (Albert and others, 1978), Talkeetna (Steele and Albert, 1978), Big Delta (N. R. D. Albert, unpub. data, 1977), Goodnews-Hagemeister Island (Steele, 1978), and Ketchikan-Prince Rupert (W. C. Steele, unpub. data, 1977) quadrangles, as part of the Alaska Mineral Resource Assessment Program (AMRAP), provides unique geologic and structural information relevant to mineral resource assessment. Interpretative techniques include visual analysis of a black and white, single-band Landsat mosaic of Alaska and various computer-generated color and black and white products (most of which are available from the EROS Data Center, Sioux Falls, South Dakota).

In the Chandalar quadrangle, several linear features correspond to geology (Brosgé and Reiser, 1964), geophysics (Cady, 1978; Barnes, 1976), and mineralization (DeYoung, 1978). One lineament and two interlineament zones seem to form boundaries for numerous rock types. Most greenschist facies units are confined to an area between all three features; many bedded sedimentary and lower grade metamorphic rocks are excluded from this area. In addition, these three lineament features are strongly related to geophysical features and to known mineralization or geochemical anomalies (Marsh and others, 1978a-e; Marsh and Wiltse, 1978). As a result of these and other observed relations, we believe that areas with a high likelihood for significant mineralization occur where any two of these lineament features intersect. Numerous mapped faults in the Chandalar quadrangle are evident on Landsat imagery, and many of these can be extended. One of these fault extensions passes through the two known porphyry copper deposits and probably warrants further study.

There are three groups of lineaments in the Talkeetna quadrangle. The first is similar to lineament patterns observed in other quadrangles in Alaska (Albert, 1975; Albert and Steele, 1976a, b) that correspond to a planetary or worldwide fracture pattern. The second group is related to the Denali fault system, and the third is probably related to local and regional tectonic events not directly associated with the Denali fault. Much of our work in the Talkeetna quadrangle corroborates geologic features and relations postulated by the field geologists. Most notable is the identification of several northeast- to east-northeast-trending lineaments that correspond to the Yentna mineral belt (Hawley and Clark, 1973) and correlate with and connect several faults mapped by Reed and Nelson (1977).

Several major lineaments in the Big Delta quadrangle correspond to faults that were suggested previously by field geologists but have remained unmapped because of the absence of ground evidence (H. L. Foster and F. R. Weber, oral commun., 1977). Recent field investigations at several areas selected on the basis of Landsat data support the existence of these faults and indicate that they may be considerably longer than was thought.

In the Goodnews and Hagemeister Island quadrangles region, approximately half of the lineaments are related to faults mapped by Hoare and Coonrad (1978). Because the locations of many of the faults mapped in this area are uncertain, the Landsat images may show the actual fault traces more accurately than do earlier maps. The lineaments also indicate that many faults are probably substantially longer than originally mapped. In addition, because so many lineaments in the area are related to mapped faults, other lineaments are likely to represent previously undetected faults.

Nearly all mapped faults in the Ketchikan and Prince Rupert quadrangles (Berg and others, 1978) are evident on the Landsat imagery. Most of the other Landsat-derived lineaments are visible in the field and correspond to fracture sets in several areas. 


\section{REFERENCES CITED}

Albert, N. R. D., 1975, Interpretation of Earth Resources Technology Satellite imagery of the Nabesna quadrangle, Alaska: U.S. Geol. Survey Misc. Field Studies Map MF-655-J, 2 sheets, scale 1:250,000.

Albert, N. R. D., Le Compte, J. R., and Steele, W. C., 1978, Interpretation of Landsat imagery of the Chandalar quadrangle, Alaska: U.S. Geol. Survey Misc. Field Studies Map MF-878-J, 2 sheets, scale 1:250,000 (in press).

Albert, N. R. D., and Steele, W. C., 1976a, Interpretation of Landsat imagery of the McCarthy quadrangle, Alaska: U.S. Geol. Survey Misc. Field Studies Map MF-773-N, 3 sheets, scale 1:250,000.

1976b, Interpretation of Landsat imagery of the Tanacross quadrangle, Alaska: U.S. Geol. Survey Misc. Field Studies Map MF-767-C, 3 sheets, scale 1:250,000. [Supersedes Open-File Report 76-850.]

Barnes, D. F., 1976, Bouguer gravity map of Alaska: U.S. Geol. Survey Open-File Report. 76-70, 1 sheet, scale $1: 2,500,000$.

Berg, H. C., Elliott, R. L., Smith, J. G., and Koch, R. D., 1978, Geologic map of Ketchikan and Prince Rupert quadrangles, Alaska: U.S. Geol. Survey Open-File Report 78-73-A, 1 sheet, scale 1:250,000.

Brosgé, W. P., and Reiser, H. N., 1964, Geologic map and section of the Chandalar quadrangle, Alaska: U.S. Geol. Survey Misc. Field Geologic Inv. Map I-375, 1 sheet, scale $1: 250,000$.

Cady, J. W., 1978, Aeromagnetic map and interpretation of the Chandalar quadrangle, Alaska: U.S. Geol. Survey Misc. Studies Map MF-878-C, 2 sheets, scale 1:250,000 (in press).

DeYoung, J. H., Jr., 1978, Mineral resources map of the Chandalar quadrangle, Alaska: U.S. Geol. Survey Misc. Field Studies Map MF-878-B, 1 sheet, scale 1:250,000 (in press).

Hawley, C. C., and Clark, A. L., 1973, Geology and mineral deposits of the Chulitna-Yentna mineral belt, Alaska: U.S. Geol. Survey Prof. Paper 758-A, p. A1-A10.

Hoare, J. M., and Coonrad, W. L., 1978, Geologic map of the Goodnews and Hagemeister Island quadrangles region, southwestern Alaska: U.S. Geol. Survey Open-File Report 78-9-B, 1 sheet, scale 1:250,000.

Marsh, S. P., Detra, D. E., and Smith, C. E., 1978a, Geochemical and generalized geologic map showing distribution and abundance of barium, arsenic, boron, and vanadium in the Chandalar quadrangle, Alaska: U.S. Geol. Survey Misc. Field Studies Map MF-878-G, 1 sheet, scale 1:250,000 (in press).

1978b, Geochemical and generalized geologic map showing distribution and abundance of copper, molybdenum, and lead in the Chandalar quadrangle, Alaska: U.S. Geol. Survey Misc. Field Studies Map MF-878-D, 1 sheet, scale 1:250,000 (in press).

-1978c, Geochemical and generalized geologic map showing distribution and abundance of nickel, cobalt, lanthanum, and yttrium in the Chandalar quadrangle, Alaska: U.S. Geol. Survey Misc. Field Studies Map MF878-F, 1 sheet, scale 1:250,000 (in press).

1978d, Geochemical and generalized geologic map showing distribution and abundance of antimony and niobium in the Chandalar quadrangle, Alaska: U.S. Geol. Survey Misc. Field Studies Map MF-878-H, 1 sheet, scale 1:250,000 (in press).

-1978e, Geochemical and generalized geologic map showing distribution and abundance of zinc in the Chandalar quadrangle, Alaska: U.S. Geol. Survey Misc. Field Studies Map MF-878-E, 1 sheet, scale 1:250,000 (in press).

Marsh, S. P., and Wiltse, M. A., 1978, Composite geochemical map showing major alteration zones, and detailed geologic maps of selected mineral prospects, Chandalar quadrangle, Alaska: U.S. Geol. Survey Misc. Field Studies Map MF-878-I, 1 sheet, scale 1:250,000 (in press).

Reed, B. L., and Nelson, S. M., 1977, Geologic map of the Talkeetna quadrangle, Alaska: U.S. Geol. Survey Misc. Field Studies Map MF-870-A, 1 sheet, scale 1:250,000 (in press).

Steele, W. C., 1978, Interpretation of Landsat imagery of the Goodnews and Hagemeister Island quadrangles region, southwestern Alaska: U.S. Geol. Survey Open-File Report 78-9-D, 1 sheet, scale 1:250,000 (in press).

Steele, W. C., and Albert, N. R. D., 1978, Interpretation of Landsat imagery of the Talkeetna quadrangle, Alaska: U.S. Geol. Survey Misc. Field Studies Map MF-870-C, 2 sheets, scale 1:250,000 (in press).

Geochemical exploration studies in Alaska

By G. C. Curtin, T. D. Hessin, R. M. O'Leary, E. F. Cooley, G. W. Day, and R. B. Tripp

Results of geochemical studies made during the 1977 field season and compilations of results from studies made during the 1976 field season outlined a number of areas of possible new mineral occurrences. At several localities in the Talkeetna quadrangle (central Alaska Range), high tin, tungsten, and beryllium values occur in stream sediments and heavy-mineral concentrates (Curtin, Karlson, Tripp, and Day, 1978). These occurrences are associated with granitic plutons of the McKinley sequence (Reed and Nelson, 1977) and probably are derived from greisen zones similar to one described by Reed and others (1978, table 1, No. 42). In addition, significant amounts of gold were found in heavymineral concentrates in several previously unreported localities on the south flank of the Alaska Range within the Talkeetna quadrangle (Curtin, Karlson, O'Leary, Day, and McDanal, 1978). These discoveries may outline additional gold occurrences similar to those in the ChulitnaYentna mineral belt on the south flank of the Alaska Range (Hawley and Clark, 1973). A number of possible base-metal occurrences were also outlined in the west half of the quadrangle (Curtin, Karlson, O'Leary, Day, and McDougal, 1978). Discovery of several previously unre- 
ported gold and scheelite occurrences in the Seward quadrangle (Kenai Peninsula) is based on high gold and tungsten values in stream sediment and heavy-mineral concentrate samples (Tripp and Crim, 1978).

In several areas in the northeastern part of the Big Delta quadrangle (east-central Alaska), heavy-mineral concentrates of stream sediment contain anomalous amounts of tin, tungsten, molybdenum, lead, zinc, and silver. This metal suite is associated with granitic plutons and suggests possible economic tin occurrences. A similar element correlation exists, to a lesser degree, in the southeastern part of the quadrangle. Anomalous amounts of copper, lead, zinc, and arsenic were detected in heavy-mineral concentrates collected near Cretaceous and Tertiary granitic stocks in the northeast part of the Goodnews quadrangle, southwest Alaska (Hessin and others, 1977). In several areas in the western part of Talkeetna Mountains quadrangle (south-central Alaska), heavy-mineral concentrates contained anomalous amounts of either gold and silver or copper and molybdenum (Karlson and others, 1977). The anomalies suggest possible previously undiscovered metal occurrences in these areas.

During the 1977 field season, approximately 6,000 samples were collected for AMRAP geochemical studies in six 1:250,000-scale quadrangles: Big Delta, Chignik, Sutwik Island, Lake Clark, Survey Pass, and Talkeetna Mountains. The main sample media collected were minus 80 mesh stream sediment, heavy-mineral concentrates of stream sediment, and rocks. Other sample media collected in several of the quadrangles included stream water, vegetation, and streambank sod. In addition, approximately 3,600 samples of stream sediment and rocks were collected by U.S. Geological Survey geologists and Alaska state geologists as part of AMRAP and Wilderness studies in various parts of Alaska. More than 8,000 of these samples were analyzed for as many as 32 elements in the Anchorage laboratory and in mobile laboratories stationed at Juneau.

\section{REFERENCES CITED}

Curtin, G. C. Karlson, R. C., O'Leary, R. M., Day, G. W., and McDanal, S. K., 1978, Geochemical maps showing the distribution and abundance of gold and silver in the Talkeetna quadrangle, Alaska: U.S. Geol. Survey Misc. Field Studies Map MF-870-E, 2 sheets, scale 1:250,000 (in press).
Curtin, G. C., Karlson, R. C., O'Leary, R. M., Day, G. W., and McDougal, C. M., 1978, Geochemical maps showing the distribution and abundance of copper, lead, zinc, and molybdenum in the Talkeena quadrangle, Alaska: U.S. Geol. Survey Misc. Field Studies Map MF-870-G, 4 sheets, scale 1:250,000 (in press).

Curtin, G. C., Karlson, R. C., Tripp, R. B., and Day, G. W., 1978, Geochemical maps showing the distribution and abundance of tin, tungsten, and beryllium in the Talkeetna quadrangle, Alaska: U.S. Geol. Survey Misc. Field Studies Map MF-870-F, 3 sheets, scale 1:250,000 (in press).

Hawley, C. C., and Clark, A. L., 1973, Geology and mineral deposits of the Chulitna-Yentna mineral belt, Alaska: U.S. Geol. Survey Prof. Paper 758-A, 10 p.

Hessin, T. D., Taufen, P. M., Seward, J. C., Quintana, S. J., Clark, A. L., Grybeck, Donald, Hoare, J. M., and Coonrad, W. L., 1977, Geochemical and generalized geologic maps showing distribution and abundance of copper, lead, zinc, and arsenic in the Goodnews and Hagemeister Island quadrangles, Alaska: U.S. Geol. Survey OpenFile Report 77-762-L-0 (in press).

Karlson, R. C., Curtin, G. C., Cooley, E. F., and Garmezy, L., 1977, Geochemical maps and results of spectrographic analyses for heavy-mineral concentrates from the western half of the Talkeetna Mountains quadrangle, Alaska: U.S. Geol. Survey Circ. 734, 23 p. (in press).

Reed, B. L., and Nelson, S. W., 1977, Geologic map of the Talkeetna quadrangle: U.S. Geol. Survey Misc. Field Studies Map MF-879-A, 1 sheet, scale 1:250,000 (in press).

Reed, B. L., Nelson, S. W., Curtin, G. C., and Singer, D. L., 1978, Mineral resources map of the Talkeetna quadrangle, Alaska: U.S. Geol. Survey Misc. Field Studies Map MF-870-D, scale 1:250,000 (in press).

Tripp, R. B., and Crim, W. D., 1978, Mineralogical map showing gold and scheelite in heavy-mineral concen. trates in the Seward and Blying Sound quadrangles, Alaska: U.S. Geol. Survey Misc. Field Studies Map MF880-J, 3 sheets, scale 1:250,000 (in press).

Stream flow and channel erosion investigations along the TAPS route

By J. M. Childers, D. Kernodle, and R. Loeffler

During spring breakup along the trans-Alaska pipeline route, project personnel measured channel erosion and flood discharge and pursued qualitative investigations of ice-flood interactions. Exceptional icings were observed at several pipeline stream crossings. These icings, incomplete construction, and, on the Sagavanirktok River, record floods combined to wash out some spur dikes and other river-training structures.

The yearly surveillance of channel erosion at 28 river crossings along the TAPS route provided another year's record for this ongoing project. This year's survey was to assess the channel ero- 
sion after completion of the pipeline at all crossings. Relatively little erosion has occured at most of the sites since the 1976 surveys. Channel changes were mainly due to construction of the pipeline during the last year. Methods of surveillance include on-the-ground surveys, photogrammetric surveys, photographic comparisons, and site visits. Evaluation of photogrammetric techniques confirmed their accuracy for channel erosion studies.

Regional appraisal of Alaska's ground-water resources

By Chester Zenone and G. S. Anderson

A compilation and review of work by earlier investigators and a survey of current water-use figures suggest that ground water is a large but virtually unexplored and undeveloped resource in Alaska. Perennially frozen ground-permafrost-influences the occurrence, movement, and availability of ground water except in the southern and southeastern coastal areas of the State. The most extensive aquifers occur in alluvium of major river valleys such as the Yukon, Tanana, Kuskokwin, and Susitna. Large amounts of ground water are also stored in glacial outwash aquifers in coastal basin and valley deposits at Anchorage, Kenai, and Juneau. Both recharge and discharge of the large alluvial aquifers are concentrated along stream channels. The authors of the summary report (to be published as a Professional Paper in 1978) estimate that 25 percent of the total volume of streamflow in Alaska (exclusive of coastal areas) is contributed by ground-water discharge.

\section{NORTHERN ALASKA}

The Arrigetch Peaks and Mount Igikpak plutons, Survey Pass quadrangle, Alaska

By S. W. Nelson and Donald Grybeck

Approximately $1,000 \mathrm{~km}^{2}$ of intrusive rocks is spectacularly exposed in the Mount Igikpak and Arrigetch Peaks plutons in central Survey Pass quadrangle. During 1977 field season these intrusive rocks were studied as part of the Survey Pass AMRAP project. The intrusive rocks were mapped and sampled to determine their compositional variation, to determine their internal structure, and to evaluate the mineralization associated with the intrusive bodies. In addition, samples were collected for geochronologic studies by M. L. Silberman.

Preliminary work indicates that the intrusive rocks are pervasively metamorphosed. Laboratory examinations indicate that the intrusive rocks are predominantly granite in composition but may range from quartz monzonite to tonalite, according to the classification scheme of Streckeisen (1973). Color index ranges from 5 to 30 . Two types of textures predominate: (1) fineto medium-grained granite and granite gneiss and (2) fine- to coarse-grained granite porphyry and augen gneiss (fig. 3). The granitic-textured rocks contain a weakly developed, megascopic metamorphic fabric. All gradations from typically granitic rocks to gneisses occur. In all samples microscopic textures indicative of regional metamorphism are moderately to well developed. These textures include (1) granulation and sutured grain boundaries of quartz and phenocrysts of potassium feldspar, (2) foliation and lineations, (3) polygonal porphyroclasts of quartz and potassium feldspar about which the foliation has been deformed, (4) mortar texture, and (5) dimensional preferred orientation of quartz.

The major minerals in the granitic rocks are perthitic microcline, quartz, plagioclase, muscovite, and biotite. No hornblende was observed. Accessory minerals include zircon (?), apatite, garnet, calcite, allanite, and fluorite. Alteration minerals that are probably related to metamorphism are sericite, chlorite, zoisite/clinozoisite, and iron oxides.

The contact of the intrusive rock, which extends for at least $300 \mathrm{~km}$ in the Mount Igikpak and Arrigetch Peaks plutons, is well exposed. In most places the contact is quite sharp and parallel to compositional layering and foliation in the adjacent metasedimentary rocks. In parts of the Mount Igikpak pluton, however, the contact is complex, and the contact zone is an intricate mixture of metasedimentary and meta-igneous rocks. Satellitic stocks of intrusive rock along the southwest part of the Mount Igikpak pluton are locally separated from each other and the main body by mixed zones, and in places intrusive rock is hard to distinguish from the mixed rocks. The intrusive nature of the contact is established by (1) the presence of large xenolithic blocks of metasedimentary rocks up to $5 \times 10 \mathrm{~m}$ in size, (2) dikes and sills of orthogneiss cutting metasedi- 
mentary rocks, (3) discordant contacts, and (4) narrow, discontinuous contact metamorphic zones containing amphibolite, garnet mica schist, and skarns.

In general, attitudes of the contact indicate that the plutons form shallow to moderately northward dipping slablike bodies, although in places this relation is complicated, in part by folding. The northward dipping, conformable aspect of the contact is especially clear along the north side of both plutons.

Folds in the plutons range from small symmetric ones with amplitudes on the order of centimeters, to isoclinal folds with amplitudes of less than a meter, to large-scale open symmetric folds with amplitudes on the order of hundreds of meters. The small-scale folds are defined by the foliation, whereas the large-scale ones are indicated by compositional layering in the gneisses. Petrofabric studies have not yet established the relations between the various folds in the intrusive rocks or between these and folds in the metasedimentary rocks. In one locality $10 \mathrm{~km}$ northeast of Akabluak Pass, however, a large antiform in the granite parallels a similar fold in the overlying metasedimentary rocks.

The plutons are mineralized, especially along their peripheries. The mineralization is reflected in numerous minor occurrences of ore minerals and marked geochemical anomalies in lead, molybdenum, tin, and silver. Only small areas of the contact zones have been examined in detail, but occurrences of molybdenite, sphalerite, chalcopyrite, galena, stibnite, and magnetite as well as skarn samples with more than 0.1 percent tin and beryllium have been located. Most occurrences of ore minerals found to date are small. The most favorable areas are the contacts of the pluton in the vicinity of Tupik Creek and an area of skarn about 200 by $300 \mathrm{~m}$ in a headwater tributary of the Takahula River (T. 22 N., R. 22 E.). Prominent yellow-orange altered zones as much as a square kilometer in area occur in the granitic rocks near Angiaak Pass (T. 24 N., R. 17 E.) and at the southeast end of the Arrigetch Peaks pluton (T. 22 and 23 N., R. 22 E.). The altered rocks

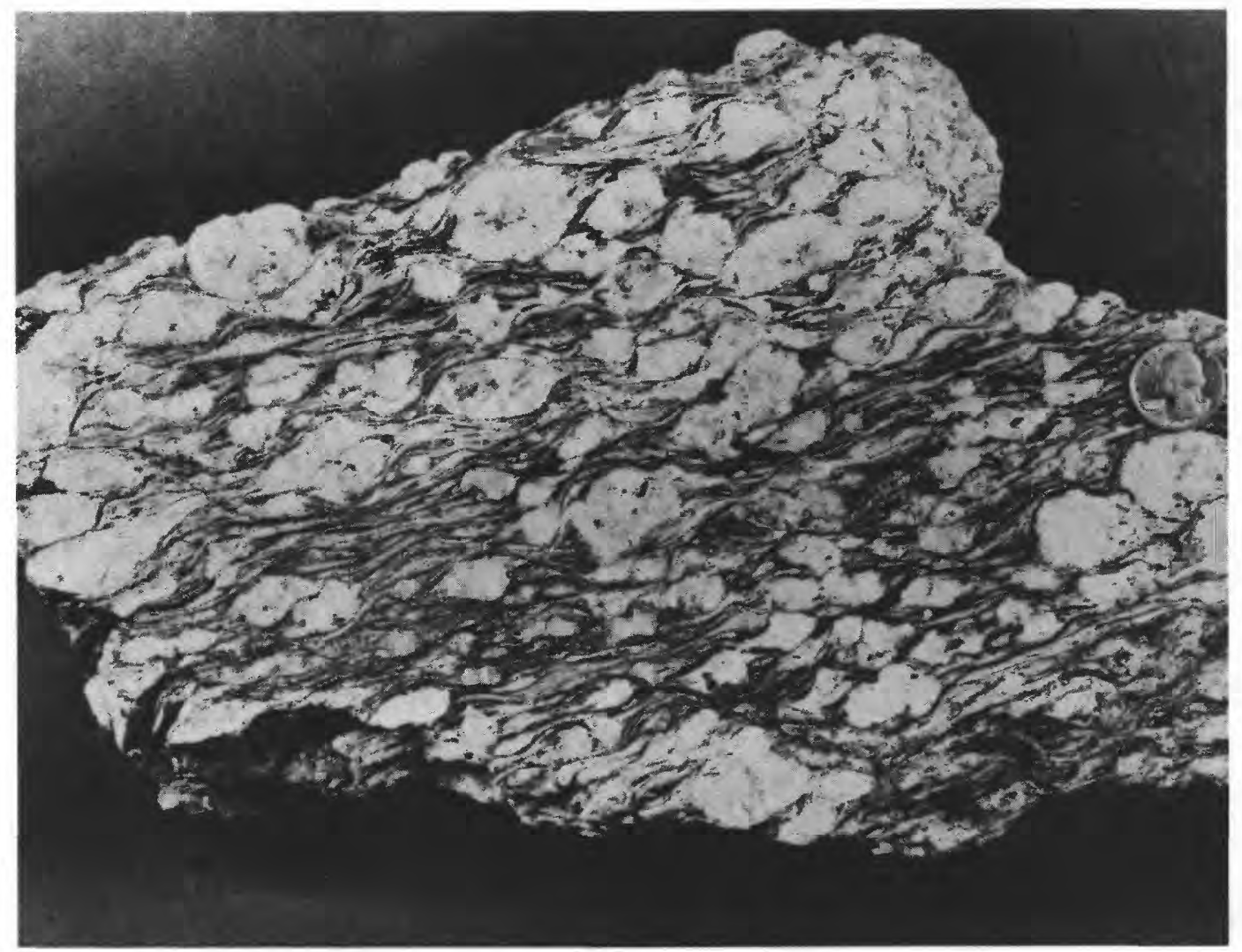

FIGURE 3.-Surface of coarse-grained augen gneiss from the Arrigetch Peaks pluton. 
consist of silicified granite poor in mafic minerals but with disseminated pyrite. Their metal content is barely above background levels. The distribution and apparently limited amount of mineralization at the periphery of the main Arrigetch Peaks and Mount Igikpak plutons suggest that a more favorable environment for substantial mineralization is in the apical zones or roof zones of similar plutons that are not so well exposed. The discovery of such buried or shallowly exposed plutons will be difficult because of the absence of deformation and narrow contactmetamorphic zones that are apparently characteristic and because of the complex structure of the surrounding metasedimentary rocks.

Previous workers (Brosgé and Reiser, 1971; Fritts and others, 1971; and Brosgé and Pessel, 1977) have suggested that these plutons are of Cretaceous age. We believe, however, that the pervasive metamorphism and complex structure in the granitic rocks may indicate that the rocks are much older, perhaps equivalent to the Paleozoic granites in the Romanzof Mountains (Sable, 1977) or the Chandalar quadrangle (Grybeck and others, 1977). The Cretaceous age of the plutons may reflect the widespread Mesozoic metamorphic event(s) in the southern Brooks Range (Turner and Forbes, 1977; Turner and others, 1978). Since the potassium-argon dates are probably tied to the pervasive metamorphic event(s) reflected in the deformation of the plutons, the age of the emplacement is uncertain. Geologic evidence is inconclusive because the youngest rock unit that is presently recognized as intruded by the granite is the Upper Devonian Hunt Fork Shale (Brosgé and Pessel, 1977). Rubidium/ strontium and lead isotope studies are underway in order to establish the age of these rocks.

\section{REFERENCES GITED}

Brosgé, W. P., and Reiser, H. N., 1971, Preliminary bedrock geologic map, Wiseman and eastern Survey Pass quadrangles, Alaska: U.S. Geol. Survey Open-File Report 7156 , scale $1: 250,000$.

Brosgé, W. P., and Pessel, G. H., 1977, Preliminary reconnaissance geologic map of the Survey Pass quadrangle: U.S. Geol. Survey Open-File Report 77-27, scale 1:250,000.

Fritts, C. E., Eakins, G. R., and Garland, R. E., 1971, Geology and geochemistry near Walker Lake, southern Survey Pass quadrangle, Arctic Alaska: Alasḱa Div. Geol. Survey Ann. Rept., p. 19-26.

Grybeck, Donald Beikman, H. M. Brosgé, W. P., Tailleur, I.
L., and Mull, C. G., 1977, Geologic map of the Brooks Range, Alaska: U.S. Geol. Survey Open-File Report 77 166-B, scale 1:1,000,000.

Sable, E. G., 1977, Geology of the western Romanzof Mountains, Brooks Range, northeastern Alaska: U.S. Geol. Survey Prof. Paper 897, 84 p.

Streckeisen, A. L., 1973, Plutonic rocks; classification and nomenclature recommended by the IUGS Subcommission on the systematics of igneous rocks: Geotimes, v. 18 , no. 10 , p. $26-30$.

Turner, D. L., and Forbes, R. B., 1977, Geochronology of the southwestern Brooks Range (abs.): Alaska Geol. Soc. Symposium, Program with Abstracts, p. 42-43.

Turner, D. L., Forbes, R. B., and Mayfield, C. F., 1978, K-Ar geochronology of the Survey Pass, Ambler River and eastern Baird Mountains quadrangles, southwest Brooks Range, Alaska: U.S. Geol. Survey Open-File Report 78-254, $41 \mathrm{p}$.

Potential strata-bound lead-zinc mineralization, Philip Smith Mountains quadrangle, Alaska

By J. T. Dutro, Jr.

Upper Devonian rocks in the Philip Smith Mountains quadrangle contain anomalous occurrences of lead, zinc, and several other metallic elements. A marine depositional cycle, initiated in the early Late Devonian, produced more than $1,200 \mathrm{~m}$ of fine-grained clastic rocks and reefoid limestone (unnamed formation). Laminated dark fine-grained limestone and black shale low in the sequence are succeeded by brown-weathering calcareous siltstone and fine-grained sandstone below the main reef horizon. Stromatoporoid reefs and biostromes, as much as $\mathbf{5 0}$ $\mathrm{m}$ thick, at as many as four levels through a 500$m$ interval, are spatially related to Silurian and Devonian structural high areas. In some places, the lower Frasnian sequence contains volcaniclastic rocks and flows, including mafic pillow lavas.

Both the Hunt Fork Shale and the underlying unnamed heterogeneous unit are widely distributed in the southern part of the Philip Smith Mountains quadrangle (Brosgé and others, 1977). These rocks, together with the overlying Kanayut Conglomerate, reflect a major onlapofflap-onlap cycle that extends into the early Carboniferous.

The unnamed formation, approximately 500 $\mathrm{m}$ thick, records five depositional cycles, three of which are capped by reefoid limestones. The overlying Hunt Fork Shale, more than $700 \mathrm{~m}$ thick, contains at least five cycles, two of which contain thin limestones in their upper parts. 
Samples from a measured sequence of these Frasnian strata were analyzed spectroscopically for manganese, chromium, cobalt, nickel, zirconium, copper, lead, and vanadium. Atomic absorption analyses were also performed for lead (D. E. Detra, written commun., 1977). Most of the anomalous values are in the ranges reported for black shales (Hawkes and Webb, 1962), although those for manganese, cobalt, and chromium exceed the black shale averages. All means are greater than those reported by Mason (1966) as typical of shales in general. At eight levels, all in the deeper water parts of the cycles, five or more elements attain peak values (fig. 4). These high values suggest that the Hunt Fork Shale could have been the source of subsequent concentration of metals in promising structural settings.

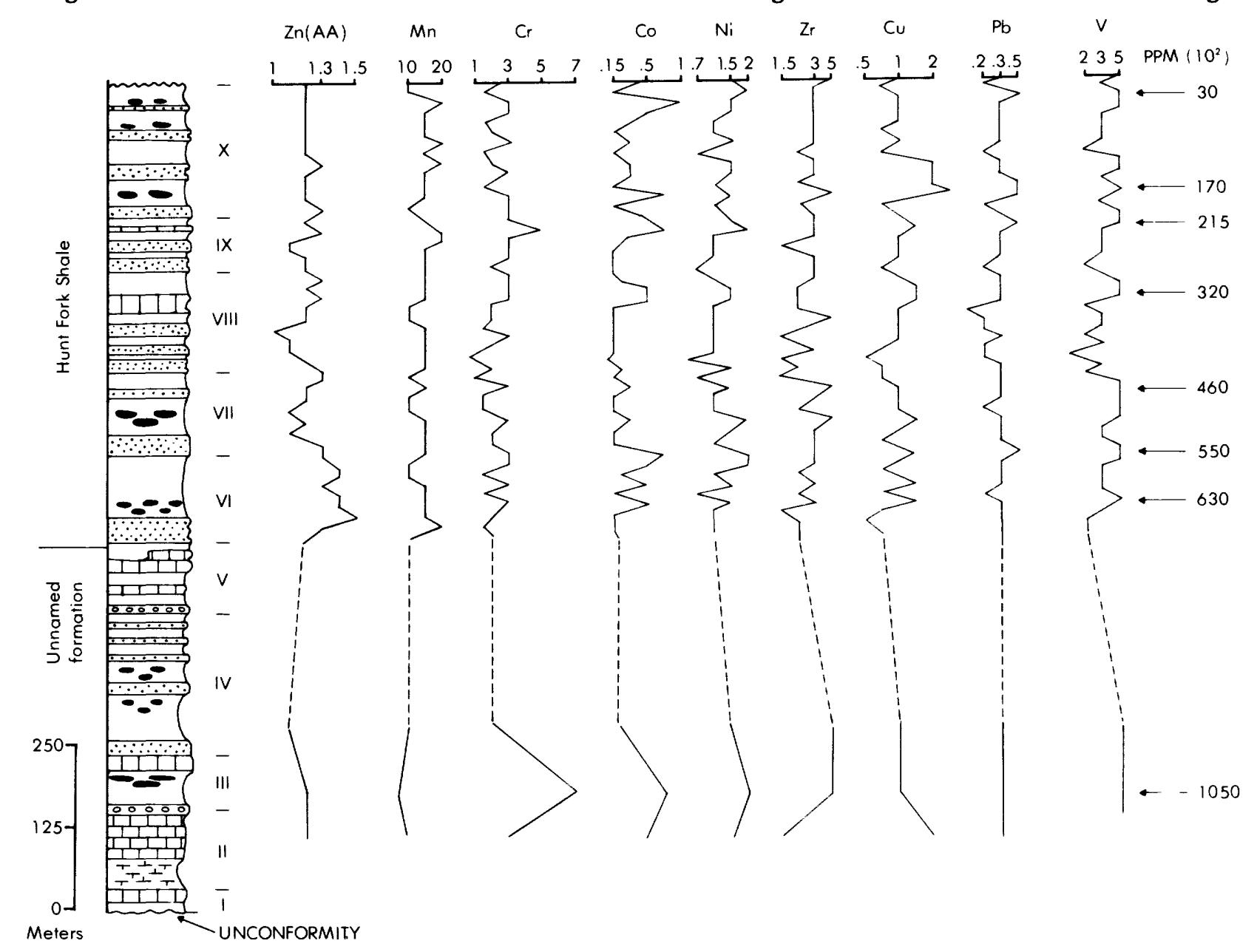

Anomalous concentrations of lead, zinc, copper, and silver are found in the Philip Smith Mountains A-2 quadrangle, near a pre-Frasnian structural high (Detra, 1977). At this location the unnamed Frasnian strata lie unconformably on earlier Devonian carbonates on which a paleokarst surface was developed. Rock samples from just above this discontinuity yield very high values for lead, zinc, copper, and silver. In each of four samples, lead values are $20,000 \mathrm{ppm}$ or more; copper ranges from 150 to 1,000 ppm; zinc ranges from 5,000 to $340,000 \mathrm{ppm}$; and silver values are 30 to $150 \mathrm{ppm}$.

Minerals present are sphalerite, pyrite, chalcopyrite, galena, and tetrahedrite (P. B. Barton, oral commun., 1977). Preliminary results of analyses of fluid inclusions give a temperature range for the original fluid of 150 to $200^{\circ} \mathrm{C}$. This range

FiguRE 4.-Generalized stratigraphic section of unnamed Upper Devonian formation and Hunt Fork Shale showing depositional cycles and variation in analyses of nine elements in rock samples taken at approximately 15-m intervals. Eight levels where five or more elements attain peak values are indicated. 
is clearly not cold, but it is also not typical of hydrothermal solutions (E. W. Roedder, oral commun., 1977).

Original high metallic values in the dark shales could have been concentrated during or after burial, and the highly metalliferous fluids might have migrated subsequently into favorable stratigraphic or structural traps either at the unconformity or above structural highs or both. Further exploration for similar structural settings should be carried out on a regional basis and potential target areas studied in greater detail to evaluate their economic potential.

\section{REFERENCES CITED}

Brosgé, W. P., Reiser, H. N., Dutro, J. T., Jr., and Detterman, R. L., 1977, Generalized geologic map of Philip Smith Mountains quadrangle, Alaska: U.S. Geol. Survey Open-File Report 77-430, scale 1:200,000.

Detra, D. E., 1977, Delineation of an anomalous lead-zinc area in the Philip Smith Mountains A-2 quadrangle, Alaska: U.S. Geol. Survey Open-File Report 77-223, $11 \mathrm{p}$.

Hawkes, H. E., and Webb, J. S., 1962, Geochemistry in mineral exploration: New York, Harper and Row, 415 p.

Mason, Brian, 1966, Principles of geochemistry (3rd ed.): New York, John Wiley and Sons, Inc., 329 p.

Granitic clasts from Upper Cretaceous conglomerate in the northwestern Brooks Range

By C. F. Mayfield, I. L. Tailleur, C. G. Mull, and M. L. Silberman

Upper Cretaceous conglomerate in the De Long Mountains and foothills of the central and western Brooks Range contains abundant lightcolored granitic clasts. This study was undertaken to determine the age and composition of these clasts because they do not have a nearby source terrane. During the 1975 and 1976 field seasons, 76 samples of granitic igneous rocks were collected in isolated conglomerate outcrops from the Killik to the Kugarok River (fig. 5). Petrographic thin sections from a few samples were studied; other samples were slabbed and stained for feldspar identification. Two clasts were dated using standard potassium-argon methods.

The conglomerate is poorly sorted and has a matrix of mudstone and wacke. Dominant clast types are chert, limestone, and a large variety of fine- to coarse-grained mafic to granitic igneous rocks. Clasts are well rounded, boulder to pebble size, and constitute more than 50 percent of the total rock volume. The largest granitic clast ob- served was $0.6 \mathrm{~m}$ in diameter. Many conglomerate outcrops are isolated local exposures; some appear to have been deposited as local channel fills rather than as a continuous sheet. At one locality conglomerate is interbedded with mudstone containing the fossilized pelecypod Buchia, indicating a probable Neocomian age. Regional mapping indicates that most conglomerate is contained within terranes that have yielded specimens of Neocomian Buchia, but a few outcrops may be correlative with the Fortress Mountain Formation of Albian age.

The sampled conglomerate is on allochthonous thrust sheets that are believed to have moved many kilometers northward during Early Cretaceous time relative to more deep-seated rocks in the Brooks Range (Tailleur and Snelson, 1969; Mull and Tailleur, 1977). Mapping suggests that most of the conglomerate was deposited before or during the time the allochthons were being moved and therefore was originally deposited an undetermined distance south of its present localities. Rocks in the allochthonous sheets located near congolmerate outcrops can account for the source of most clasts except the granitic types, which have no readily apparent source.

A wide range of igneous compositions is represented in the conglomerate. Mafic rocks, such as basalt and diabase, are abundant and are not considered in this discussion because they occur throughout the Brooks Range. The granitic rocks range in composition from quartz monzonite to diorite, and their volcanic equivalents are nearly as abundant. The sampling included 55 percent quartz diorite or dacite clasts, 29 percent diorite or andesite clasts, and 16 percent quartz monzonite, grandiorite, or quartz latite clasts, Feldspar, quartz, biotite, and hornblende are the most common igneous mineral constituents.

Potassium-argon dates were obtained on hornblende separated from quartz diorite clasts collected from two different localities. A sample collected $5 \mathrm{~km}$ south of Migrant Lakes (locality no. 1, fig. 5) gave an age of $153 \pm 5$ m.y., and a sample from a tributary of upper Nunaviksak Creek (locality no. 2, fig. 5) gave an age of $186 \pm 9$ m.y. The ages should be considered minimum figures, but hornblende retains aragon well so these dates suggest that most of the granitic clasts are of Jurassic age.

These age and composition data suggest at least five possible source terranes for the granitic 

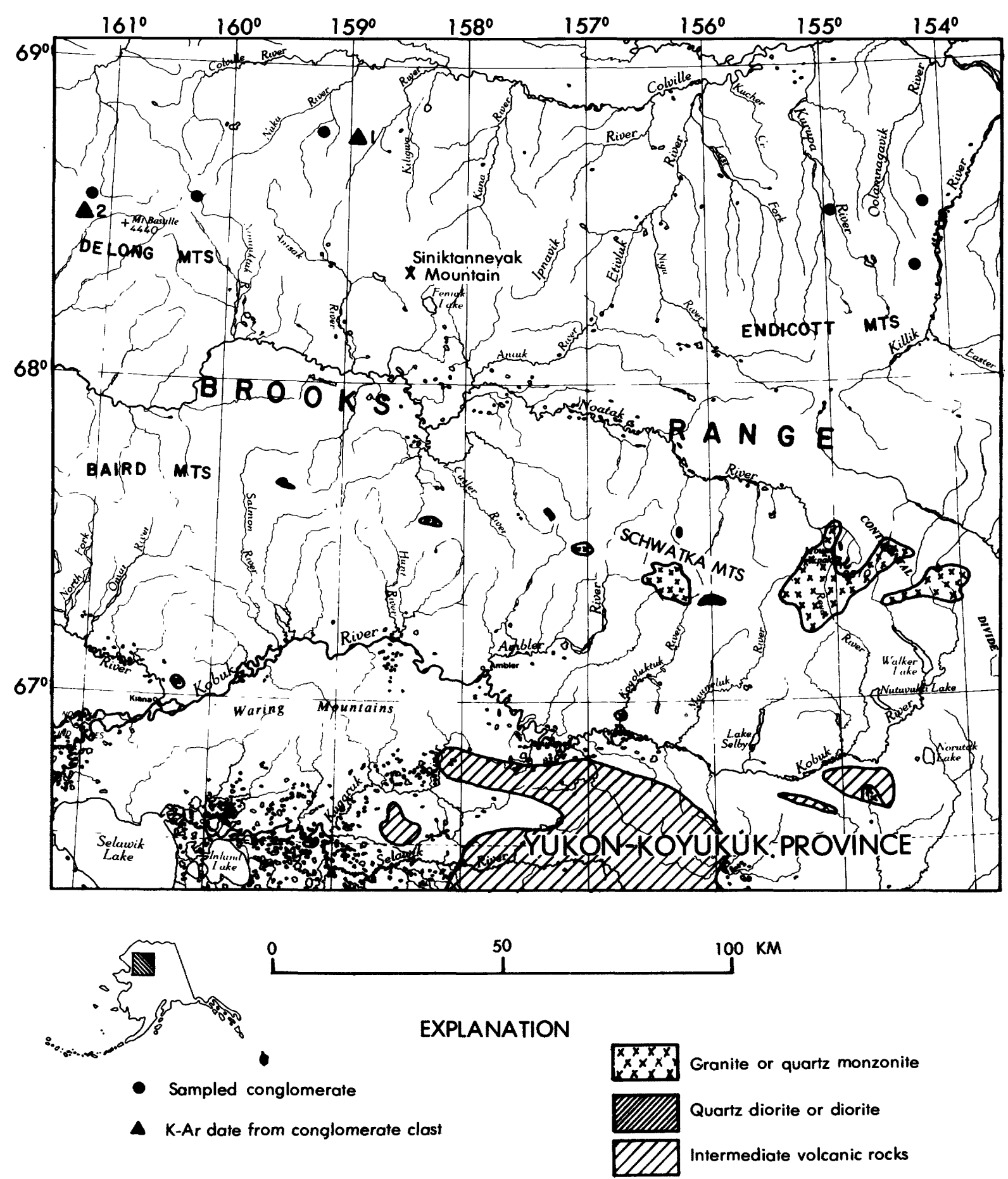

FIGURE 5.-Location of sampled conglomerate and potential igneous source areas, northwestern Brooks Range.

clasts: (1) the belt of plutons in the Schwatka and Baird Mountains of the southern Brooks Range; (2) a buried terrane in the Brooks Range that is now covered by large thrust sheets; (3) the terrane of felsic volcanic rocks in the YukonKoyukuk Province; (4) the felsic plutonic and volcanic phases of mafic and ultramafic allochthons in the west-central Brooks Range; and (5) 
an upper thrust sheet that has been removed by erosion.

The first possibility, that the clasts were derived from plutons in the Schwatka and Baird Mountains, is the most obvious, but it has several difficulties. The compositions of the plutons are mostly granite or quartz monzonite, whereas clasts in the conglomerate are mostly quartz diorite or diorite (fig. 5). The east to west distribution of the plutons does not adequately explain the abundance of clasts to the west in the De Long Mountains. In addition, regional relations suggest that the conglomerate is on some of the structurally highest thrust sheets, which are interpreted as having overlain the core area of the southern Brooks Range (Mull and Tailleur, 1977). Thus, the granitic rocks forming the core of the range would not have been exposed for erosion and subsequent deposition on these structurally high sheets.

The second possibility, a buried terrane within the Brooks Range, is unlikely owing to the structural position of the conglomerate relative to the core of the Brooks Range.

The third possibility, that the source terrane was felsic rocks in the Yukon-Koyukuk Province, is unlikely because no potassium-argon dates from granitic igneous rocks of this area are older than Early Cretaceous (W. W. Patton, oral commun., 1977).

If it is accepted that the first three suggested source terranes are unlikely because of the composition, age, and structural position of the granitic clasts, then it is necessary to consider the possibility that the clasts are derived from structurally higher allochthons that have been partly or completely removed by erosion. The fourth possibility, that the source of the granitic clasts was from felsic phases of the mafic-ultramafic allochthons in the west-central Brooks Range, is speculative. Remnants of these allochthons are preserved as klippen in the De Long and western Endicott Mountains, where they are the highest structural unit of a series of allochthonous sheets (Roeder and Mull, 1978). Small amounts of granitic rocks occur at Siniktanneyak Mountain (fig. 5) and near Asik Mountain east of Noatak Village (U.S. Bureau of Mines, unpub. data, 1976). At Siniktanneyak, plutonic and volcanic granitic rocks appear to be differentiated phases from gabbro. Most of these rocks, however, have a high feldspar content but little quartz, unlike most of the conglomerate clasts, many of which have abundant quartz. If extensive granitic phases of these allochthons ever existed, they have been removed by erosion.

The final possibility for the source of the granitic clasts is that they were derived from a now completely eroded allochthonous igneous terrane of Jurassic age. Regional structural, stratigraphic, and petrographic relations favor this interpretation. If the rocks of the west-central Brooks Range have been displaced as much as has been suggested by Mull, Tailleur, Mayfield, and Pessel (1976), then the source of the clasts would probably have been from an igneous terrane originally located south of the present Brooks Range.

\section{REFERENCES CITED}

Mull, C. G., and Tailleur, I. L., 1977, Sadlerochit Group in the Schwatka Mountains, south central Brooks Range, in Blean, K. M., ed., The United States Geological Survey in Alaska; accomplishments during 1976: U.S. Geol. Survey Circ. 751-B, p. B27-B29.

Mull, C. G., Tailleur, I. L., Mayfield, C. F., and Pessel, G. H., 1976, New structural and stratigraphic interpretations, central and western Brooks Range and Arctic Slope, in Cobb, E. H., ed., The United States Geological Survey in Alaska; accomplishments during 1975: U.S. Geol. Survey Circ. 733, p. 24-26.

Roeder, Dietrich, and Mull, C. G., 1978, Tectonics of Brooks Range ophiolites: Am. Assoc. Petroleum Geologists Bull. (in press).

Tailleur, I. L., and Snelson, Sigmund, 1969, Large scale thrusting in northwestern Alaska possibly related to rifting of the Arctic Ocean: Geol. Soc. America Spec. Paper 121, p. 569.

Cretaceous Nanushuk Group, North Slope, Alaska By Thomas S. Ahlbrandt and A. Curtis Huffman

The Cretaceous Nanushuk Group, where exposed on the North Slope (see fig. 2, area 1), is a regressive depositional sequence including marine, transitional, and nonmarine intervals and ranges in thickness from about 1,800 to $2,700 \mathrm{~m}$ (fig. 6). Preliminary data and previous work indicate that there are at least two depocenters in the Nanushuk Group, one in the eastern part of the National Petroleum Reserve in Alaska (NPRA), and one to the west. The rocks contained within the two depocenters differ in detrital composition, stratigraphic sequence, and sand:shale ratios. For example, coal occurs lower in the eastern sequence than in the western sequence, 
Nanushuk Group

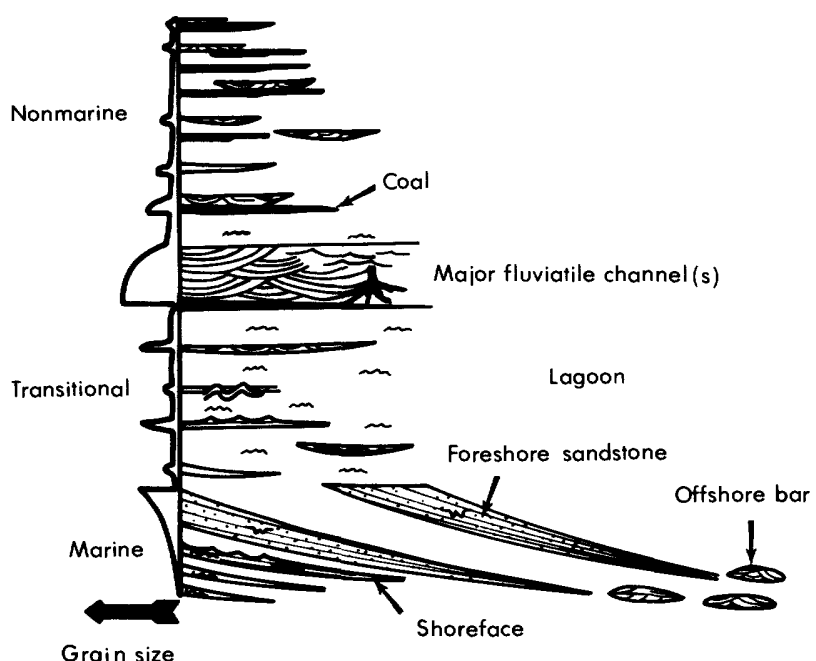

FIGURE 6.-Generalized stratigraphic sequence of Cretaceous Nanushuk Group, western North Slope, Alaska.

and sandstone constitutes a greater percentage of the Nanushuk Group in the eastern depocenter.

In order to assess the resource potential of the Nanushuk Group within NPRA, concurrent surface and subsurface studies are being conducted that will later be integrated and compared with geophysical results through a computer file being established by Petroleum Information, Denver. During the 1977 field season, 22 sections totaling $14,600 \mathrm{~m}$ were measured and described in detail. This work was conducted primarily in the western part of the northern foothills region but also included several of the type localities to the east. Data recorded at each outcrop and in the cores included color; grain size; sorting, roundness, percent framework and porosity estimates; sedimentary structures; bedding thickness; lamination types and style; biologic constituents, including trace fossils; transport directions in fluvial sandstone; and radiometric readings. These observations were made at 3- to 4-m intervals in sandstone and wherever possible in siltstone and shale. Laboratory analyses are currently being conducted on a total of 1,430 samples collected from the outcrops. These include 382 samples for petrographic, porosity and permeability, and delayed neutron studies; 295 for organic geochemistry analyses; 418 for dinoflagellate, pollen, and spore content; and 285 for foraminifer content; 48 samples are being col- lected from the cores for petrographic, porosity and permeability, and delayed neutron analyses. Data from these studies will be included in the computer file as they become available.

Depositional environments of sandstone in the western area were differentiated primarily on the basis of sedimentary structures, lateral and vertical stratigraphic position, and trace fossil assemblages. The nearshore marine sandstone include shoreface, foreshore, and offshore-bar deposits (fig. 6). Shoreface sandstones are thin ( $\leq 5 \mathrm{~m}$ ) and commonly have contorted basal zones, grading upward into low-angle crossbeds with symmetrically rippled upper surfaces crossed by trace fossils. Common trace fossils include Gyrochorte (snail trails), Helicodromites (spiral burrows), and Arthrophycus; occasionally Asterosoma and unnamed large-diameter (5- to 10-cm-wide) burrows are found. The shoreface sandstones gradually become thicker up section and are replaced by the prominent foreshore sandstones (5-10 $\mathrm{m}$ thick) that are flat-bedded or low-angle crossbedded and contain relatively few trace fossils; Diplocraterion and Skolithos are most common. Although separated by siltsone or shale, the foreshore sandstones are imbricated and grade laterally basinward into isolated sandstone lenses that are commonly less than $10 \mathrm{~m}$ thick and $60 \mathrm{~m}$ wide and are interpreted as offshore bars (fig. 6). The lenses decrease in size away from the foreshore sandstones and pass lateraily into siltstone or shale.

The transitional interval (fig. 6) represents mixing of marine and nonmarine sediments, probably in a lagoonal or backshore environment. Isolated thin ( $\leq 5 \mathrm{~m}$ ) sandstones containing distinctive marine trace or megafossils are interspersed with channel sandstones lacking trace fossils. Many environments of deposition and energy levels are represented including estuarine, tidal flat, fluviatile channel, eolian, and storm deposits (washover fans?). Marine (and probably brackish water) sandstones in the transitional interval are contorted, symmetrically rippled, may show ball and pillow structures, and contain a variety of trace fossils including Arenicolites, Rossellia, Rhizocorallium, Diplocraterion, Asteriacites (star fish traces), and plural tubes. Nonmarine sandstones occur as stratigraphically isolated channels, crevasse splays, and thin sheet sands of possible lacustrine origin. The channel sandstones are commonly 5 to $10 \mathrm{~m}$ 
thick, less than $200 \mathrm{~m}$ wide, and consist of trough crossbed sets grading laterally or vertically into asymmetric climbing ripple structures (fig. 6). Normally they are not deformed, except for minor channel slumps, and trace fossils are limited to root traces, borings in fossilized logs, and rare dinosaur(?) footprints.

The major channels are 10 to $30 \mathrm{~m}$ thick and contain thin conglomerate beds or pebble lags composed of chert, carbonate clasts, and quartzite (fig. 6). Channel size decreases markedly above the major channels. Stumps of fossil trees, some in original growth position, are commonly found near the bases of such channels. Coal is more common in the upper part of the nonmarine section but was not observed to be thicker than $4.3 \mathrm{~m}$. This part of the section is interpreted as having been deposited on a delta plain.

Paleotransport studies indicate northeasterly transport of sediment in channels of the Nanushuk Group in the western area. Such data support Chapman and Sable's (1960) interpretation of northwest-southeast oriented paleoshorelines of the Nanushuk Group but differ with Smiley's (1969) interpretation of a north-south orientation in the western area. Higher energy environments, particularly the foreshore sandstones, have the best hydrocarbon reservoir potential because they have (1) the best visible porosity in outcrop, and maximum thickness ( $\leq 25 \mathrm{~m}$, commonly 5 to $10 \mathrm{~m}),(2)$ an adjacent hydrocarbon source (marine shale), (3) lateral continuity along the paleoshoreline, and (4) a relatively stable composition owing to removal of diagenetically unstable grains under high-energy conditions.

Biostratigraphic zonation of the Nanushuk Group now seems possible with dinoflagellates, spores, pollen, and foraminifers. Spores and pollen have been recovered from rocks previously thought to be barren, and dinoflagellate zonation has been completed for the Fish Creek test well. The end result of the environmental, laboratory, and geophysical studies will be an assessment of the reservoir potential of the Nanushuk Group within NPRA for hydrocarbons and uranium and thorium.

\section{REFERENCES CITED}

Chapman, R. M., and Sable, E. G., 1960, Geology of the Utukok-Corwin region, northwestern Alaska: U.S. Geol. Survey Prof. Paper 303-C, p. 47-167.
Smiley, C. J., 1969, Floral zones and correlations of Cretaceous Kukpowruk and Corwin Formations, northwestern Alaska: Am. Assoc. Petroleum Geologists Bull., v. 53, p. 2079-2093.

Geologic investigations of metallic mineral resources of southern NPRA

By Michael Churkin, Jr., Carl Huie, C. F. Mayfield, and Warren J. Nokleberg

Geologic field investigations during the summer of 1977 were concentrated in the southern part of NPRA, an area whose mineral resource potential is little known (fig. 7). Preliminary work determined that iron-stained zones, formed from weathering of accessory pyrite, were confined mainly to a thin stratigraphic interval in a structural sequence that is discontinuously covered by overlying thrust plates of coeval rocks of different lithologies (fig. 8). Lead and zinc mineral deposits in two distinct areas, Red Dog and Drenchwater Creeks (fig. 7), occur in stained zones having the same stratigraphic and structural setting.

The Brooks Range and its northern foothills in southern NPRA consist of numerous thrust plates with complex stratigraphy. The bedrock is intensely folded and faulted with relatively thin $(500 \mathrm{~m})$ sequences of marine sedimentary strata of Paleozoic and Mesozoic age. For this reason, major thrust plates are regarded as structural sequences. Rocks of the lowest recognizable structural sequence are mainly fine-grained siliceous clastic sedimentary rocks-shale, siltstone, and minor sandstone interbedded with radiolarian chert and, locally, submarine volcanic rocks. The

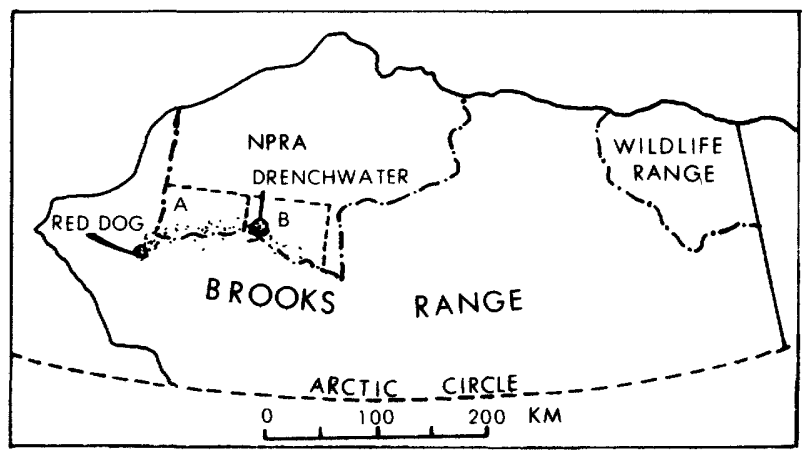

FiguRE 7.-Sketch map showing location of mineral resource assessment studies in southern NPRA (A, Misheguk Mountain quadrangle; B, Howard Pass quadrangle). Stippled pattern indicates area of mineral potential. 


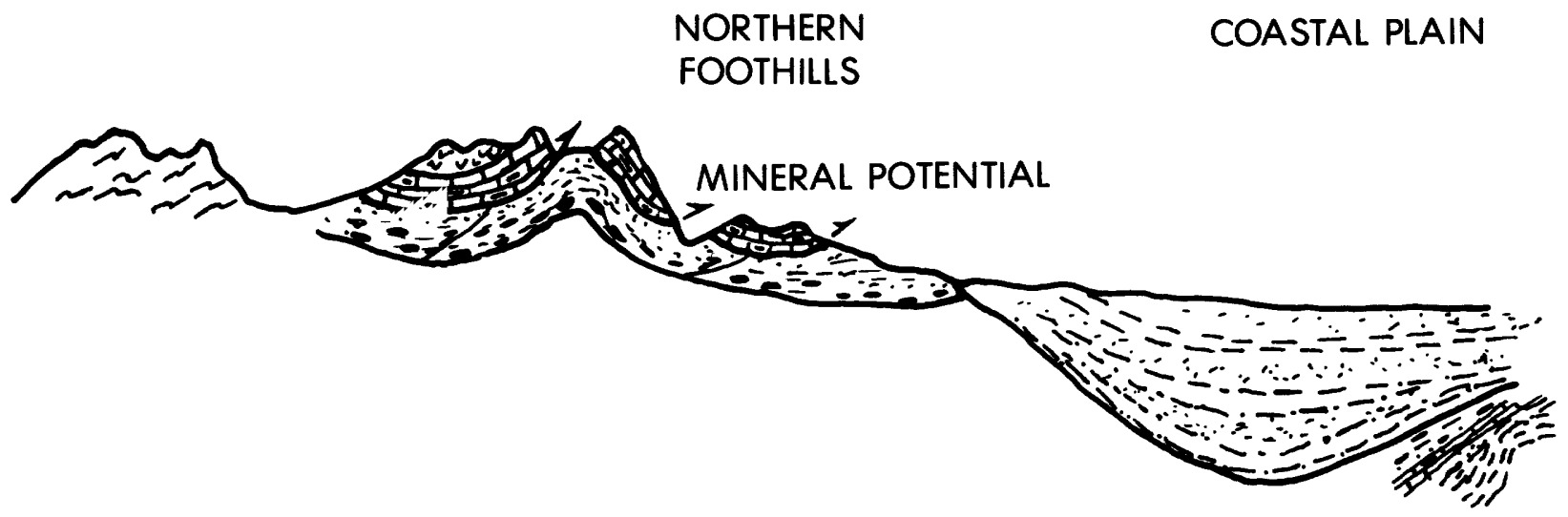

FIGURE 8.-Schematic section across the Brooks Range and the North Slope.

stratigraphy of the lowest structural sequence, which has the only significant base-metal deposits, is generalized in a columnar section (fig. 9). At the base of the section, black shale and chert of the Lisburne Group are overlain by argillite and chert of the Siksikpuk Formation that in turn are overlain by limy chert, limestone, and shale of the Shublik Formation. This thin stratigraphic interval, of Carboniferous, Permian, and Triassic age, is overlain by a thick section of coarse clastic rocks of Cretaceous age. The strata in the overlying structural sequence are characterized mainly by carbonates.

The lowest structural sequence is broken up by a series of smaller fault slices that form lenslike blocks usually striking east-west and dipping steeply south. The fault slices generally are a few hundred meters long and a few tens of meters wide. Beds within the blocks are tectonically stretched and dismembered into broken formations. Internal folds are tight and nearly isoclinal. The Drenchwater Creek area is an example of the structural complexity where the lowest structural sequence consists of a tectonic breccia.

During our field studies, we recognized significant potential for zinc-lead deposits along a moderately well delineated regional trend of chert, shale, and volcanic rocks of similar ages within the lowest structural sequence. Sulfide deposits in the Drenchwater Creek area formed contemporaneously with submarine volcanism and deposition of shale and chert of the Lisburne Group during Mississippian time. Sphalerite, ga- lena, and pyrite occur in tuff or in dark chert and shale that are either interbedded with or adjacent to tuff. Barite is sparser and occurs in black chert of the Lisburne Group and undiffer-

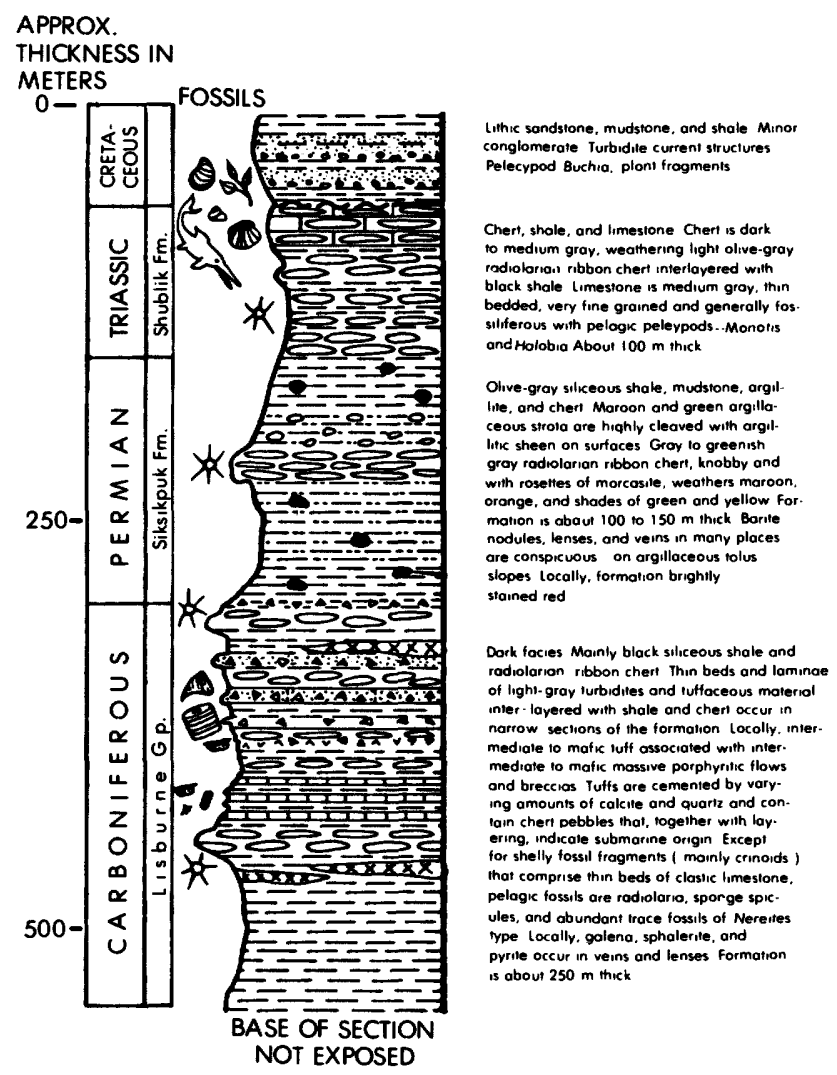

FIGURE 9.-Generalized columnar section, lowest structural sequence, southern NPRA. 
entiated gray-green chert of the Siksikpuk Formation.

Two major geologic controls for the occurrence of sulfide deposits along the northern front of the Brooks Range have been deduced from detailed mapping in the Drenchwater Creek area and from detailed traverses along the northern front. First, in the Drenchwater Creek area, the association of sphalerite and galena with submarine tuff and adjacent dark chert and shale strongly suggests that: (1) sulfide mineralization was syngenetic and stratiform, that is, mineralization occurred at the same time as or just after sedimentation and volcanism; and (2) volcanic exhalations were the source of the mineralizing fluids. Second, intense deformation, including isoclinal folding, faulting, and development of broken formations, has severely disrupted a stratigraphic horizon favorable for the localization of base-metal sulfide deposits.

Sparse nodules of barite are widely distributed throughout the Siksikpuk Formation in southern NPRA, and moderate geochemical concentrations of placer barite occur in the streams draining the northern foothills of the Brooks Range. Typical values of barium range from $1,000 \mathrm{ppm}$ to greater than $5,000 \mathrm{ppm}$ in stream sediments and from $200 \mathrm{ppm}$ to more than $5,000 \mathrm{ppm}$ with an average value of 1,500 to $2,000 \mathrm{ppm}$ in selected rock samples ( $\mathrm{P}$. Theobald, written commun., 1977). The source of placer barite is most likely residual concentration of barite from sparsely scattered nodules or disseminated grains and veinlets in various rock units.

In summary, our studies have revealed that the lowest structural sequence in the northern Brooks Range consists of a highly deformed sequence of chert, shale, sandstone, and sparse submarine volcanic rocks of Mississippian to Early Cretaceous age. We have recognized a significant potential for zinc and lead sulfide deposits in a thin stratigraphic interval in the lowest structural sequence. The zinc and lead deposits were formed in a deep marine volcanogenic environment. Finally, the potential for placer barite in southern NPRA is significant.

Stratiform zinc-lead mineralization, Drenchwater Creek area, Howard Pass quadrangle, western Brooks Range, Alaska

By Warren J. Nokleberg and Gary R. Winkler

The geologic setting and controls of zinc and lead mineralization in the Drenchwater Creek area were analyzed by detailed geologic mapping during the summer of 1977 as part of a mineral resource assessment of the northern foothills of the Brooks Range within the National Petroleum Reserve of Alaska. The area is located in the western part of the Howard Pass quadrangle (fig. 7), which was partially mapped by Tailleur, Kent, and Reiser (1966). During fieldwork in 1950-53, 1976, and 1977, I. L. Tailleur (oral commun., 1977) observed iron staining from weathered sulfide minerals, sphalerite, and minor barite in dark chert and shale in the lower part of the Lisburne Group along Drenchwater Creek. He also noted the similarity of iron staining, sulfide minerals, and host rocks between the Drenchwater Creek area and the Red Dog Creek area in the De Long Mountains, about $160 \mathrm{~km}$ west of Drenchwater Creek.

The bedrock geology of the Drenchwater Creek area consists of the lower part of the Lisburne Group (Mississippian), Siksikpuk Formation (Permian), Shublik Formation (Triassic), Okpikruak Formation (Cretaceous), and minor diabase dikes that cut all bedrock units. The Mississippian through Triassic units are mainly chert and shale. Minor volcanic rocks, volcaniclastic rocks, impure limestone, and dolomite also occur in the lower part of the Lisburne Group but are not common regionally. These rocks generally indicate deep-sea sedimentation and volcanism. The graywacke, siltstone, and mudstone of the Okpikruak Formation are tectonically interleaved with all older units. In other parts of the Brooks Range, the Okpikruak Formation unconformably overlies all older rocks and apparently indicates initial uplift of the ancestral Brooks Range geanticline, which was formed in the late Mesozoic. No stratigraphic unit is fully exposed in the Drenchwater Creek area because of intense folding, faulting, and shearing. Each of the Mississippian through Triassic units is relatively thin; maximum thickness is $150 \mathrm{~m}$. The thickness and lateral extent of units are quite variable, with many discontinuous lenses of various formations (fig. 10). In the Drenchwater Creek area, intermediate to mafic tuff, tuffaceous sandstone, and shallow sills or flows occur locally in the lower part of the Lisburne Group (fig. 10). Biotite from one shallow sill or flow has been dated by potassium-argon methods as 319 m.y. or Late Mississippian (Tail- 


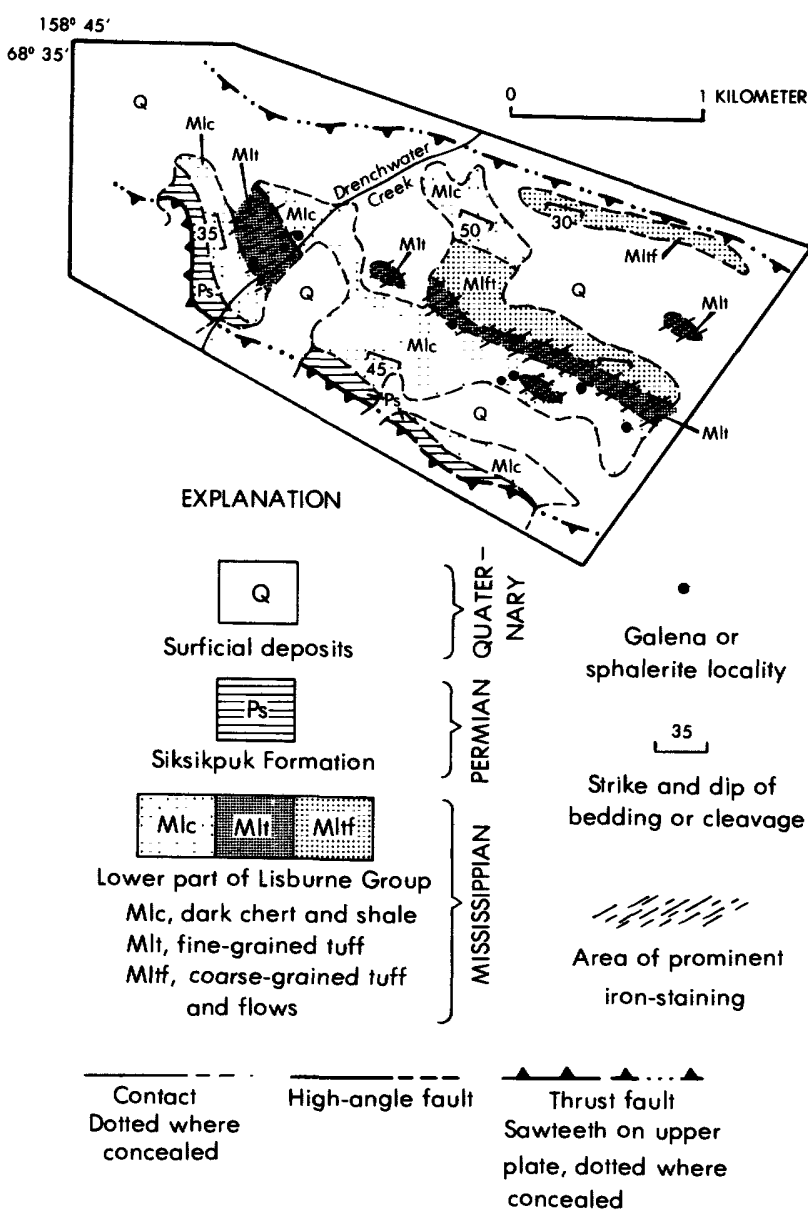

FiguRE 10.-Simplified geologic map of the Drenchwater thrust plate, Drenchwater Creek area, Howard Pass quadrangle, Alaska.

leur and others, 1977). Similar volcanic and volcaniclastic rocks also occur in the Red Dog Creek area, in conjunction with galena and sphalerite mineralization (Tailleur, 1970). Galena, sphalerite, and pyrite occur either in tuff, as on the west side of Drenchwater Creek, or in dark chert and dark shale interbedded with tuff, as along Drenchwater Creek and east of the creek.

The prevailing bedrock structure is a coarsegrained tectonic breccia marked by interleaved, fault-bounded lenses of the various formations that pinch out within a few hundred or thousand meters. The mixture of lenses of various formations is quite evident in most parts of the map area. Despite the intense deformation, discrete thrust plates can be separated. Each thrust plate is defined by distinct proportions of various formations and distinct structural domains. The thrust plates in turn may be larger tectonic slivers in an even coarser tectonic breccia. The tectonic breccia appears to extend at least several tens of kilometers to the west and perhaps many tens of kilometers to the east along the northern front of the Brooks Range. Additional work during 1978 will focus on the extent of this deformational belt. The tectonic breccia is a new definition of the disturbed belt originally described by I. L. Tailleur (oral commun., 1977). Minor structures, which mimic the major structures, consist of pervasive cleavages, dismembered lenses of various lithologies, and sparse, isoclinal minor folds. The planar structures and bedding generally strike east-west and dip moderately south. The major and minor structures were formed during a single period of deformation, during which blocks from the north were thrust and folded under blocks to the south.

All the galena and sphalerite occur in a 6- to 30-m-wide zone that extends eastward along strike from Drenchwater Creek for about 1,830 $\mathrm{m}$. The zone of sulfide mineralization is restricted to the Drenchwater thrust plate. Sphalerite and galena occur primarily as disseminated grains in undeformed fragments of rock, suggesting that sulfide crystallization occurred coincidentally with sedimentation. Less commonly, sphalerite and galena occur in 1- to 2-cm-thick veins of massive sulfides in brecciated chert and shales. Locally the veins crosscut cleavage, suggesting a period of remobilization. Analyses of 24 rock, soil, and stream sediment samples from the zone of mineralization show zinc values of 0 to greater than $10,000 \mathrm{ppm}$ with an average of about $200 \mathrm{ppm}$ and show lead values of 20 to $15,000 \mathrm{ppm}$ with an average of about $200 \mathrm{ppm}$.

There are two major geologic controls for the galena and sphalerite mineralization. First, the unique occurrence of galena and sphalerite in tuff or dark chert and shale adjacent to tuff strongly suggests that sulfide mineralization is stratiform and that volcanic exhalations were the source of mineralizing fluids. And second, intense deformation including isoclinal folding, faulting, and dismembering of formations, has severely disrupted the former stratiform deposit. A more extensive stratigraphic horizon that was favorable for zinc-lead mineralization may have extended from the Red Dog Creek area to the Drenchwater Creek area, but now consists of dismembered lenses either hidden at depth or 
rarely exposed at the surface as at Drenchwater Creek.

\section{REFERENCES CITED}

Tailleur, I. L., 1970, Lead-, zinc-, and barite-bearing samples from the western Brooks Range, Alaska, with a section on petrography and mineralogy by G. D. Eberlein and Ray Wehr: U.S. Geol. Survey Open-File Report, 16 p.

Tailleur, I. L., Kent, B. H., Jr., and Reiser, H. N., 1966, Outcrop/geologic map of the Nuka-Etivluk region, northern Alaska: U.S. Geol. Survey Open-File Report, scale $1: 63,360,7$ sheets.

Tailleur, I. L., Ellersieck, I. F., and Mayfield, C. F., 1977, Mineral resources of the western Brooks Range, in Blean, K. M., ed., The United States Geological Survey in Alaska; accomplishments during 1976: U.S. Geol. Survey Circ. 751-B, p. 24-25.

Surficial geology of the foothills and mountains of NPRA

By Warren Yeend

A piedmont-type glacier covered a substantial part of the northern slope of the western Brooks Range within NPRA and extended into the northern foothills of the range in early or middle Pleistocene time. This glaciation had been previously recognized in the extreme eastern part of NPRA where it reached almost to the Colville River (Chapman and others, 1964). As the range becomes progressively lower to the west, the ice was correspondingly more restricted. The ice did not extend further west than the Utukok River drainage basin because of the limited source area available at a sufficiently high elevation to nourish glaciers west of this area. Much of the till deposited by this ice sheet has been eroded, leaving resistant erratics scattered on bedrock. However, the ice had a marked effect on the topography, producing rounded, low, subdued hills and ridges and broad valleys up to and within the high parts of the range. Remnants of gravel outwash terraces, deposited as the ice melted or soon after, are generally 40 to $60 \mathrm{~m}$ above the present streams and rivers. They are present along the major north-flowing tributaries of the Colville River as well as along the Colville River itself. Although it does not drain glaciated terrain, the Kokolik River valley, west of the Utukok River, possesses gravel terraces at a similar topographic position relative to the present drainages, 40 to $60 \mathrm{~m}$ above present river levels. These alluvial terraces can be traced into a suspected beach gravel at the inland margin of the coastal plain at an elevation of 120 to $150 \mathrm{~m}$. If the terraces and beach gravel can be correlated, then the high sea level marked by the beach gravel most likely reflects the interglacial immediately following the extensive Pleistocene glaciation.

Late Pleistocene glaciation is represented only in the southeast corner of NPRA, where ice reached down the Nigu River valley slightly beyond the mountain front, and by two very small exposures of till with associated fresh cirques in the headwaters of Driftwood Creek. Most of the area on the North Slope within NPRA was too low to nourish glaciers during late Pleistocene time and probably lay in the precipitation shadow of a southerly moisture source. Directly across the range to the south, the record of late Pleistocene glaciation is rich.

Surficial deposits, except a 1- to 3-m-thick regolith, are generally absent from the low foothills of NPRA north of the Colville River. This area is characterized by broad, east-west trending, appalachian-type folds developed in Cretaceous sedimentary rocks-sandstone, conglomerate, siltstone, shale, and coal. The inland boundary of unconsolidated sediments of the coastal plain grades into the regolith of these sedimentary rocks in such a way that the boundary is difficult to map without subsurface information. The contact is questionably placed near the 500 -foot $(150-\mathrm{m})$ contour throughout much of the area. In the areas bounded by the Utukok and Meade Rivers, however, bedrock with associated regolith is present at the surface with little if any coastal plain deposits out to the 100 - to 200 -foot (30- to $60-\mathrm{m}$ ) contour, which is near the northern boundary of the Utukok River and Lookout Ridge quadrangles.

The Colville River, which flows in an easterly direction for much of its course $(350 \mathrm{~km})$ following the valley cut in the weak shale of the Lower Cretaceous Torok and Fortress Mountain Formations, at an earlier time extended even further to the west. High-level, ancestral Colville River gravels can be traced with confidence to Driftwood Creek where they are perched $160 \mathrm{~m}$ above the present river valley. It seems clear the ancestral Colville River was beheaded by the Kokolik River and subsequently the Utukok River and is about to be beheaded once again by a north-flowing tributary of Disappointment Creek.

Mass-moved deposits are not common in the foothills of NPRA. Talus and block rubble sur- 
round some of the high ridges and hogbacks, such as Meat Mountain. Earthflows, slumps, and soil and debris flows are present on river banks where permafrost melts as the river impinges on a steep bank and rarely on south-facing slopes underlain by fine-grained, ice-rich deposits. On these slopes summer insolation causes melting, and soil and vegetation of the active layer flow or slide on the underlying permafrost. Solifluction, although sporadically present, does not seem to be a dominant process in slope lowering at present, as it is in areas south of the Brooks Range.

\section{REFERENCE CITED}

Chapman, R. M., Detterman, R. L., and Mangus, M. D., 1964, Geology of the Killik-Etivluk Rivers region, Alaska: U.S. Geol. Survey Prof. Paper 303-F, p. 325-407.
Coastal plain deposits of NPRA

By John R. Williams, L. David Carter, and Warren E. Yeend

The general character and distribution of unconsolidated deposits in the northern Alaska coastal plain within the bounds of NPRA (fig. 11) are the subject of this study. Fieldwork, begun in 1977 (Williams and others, 1977), is scheduled to continue another summer and is done in support of Chapters 105b (Environmental Impact Assessment) and 105c (Land-Use Study) of the National Petroleum Production Act of 1976 (PL 94-258). Fieldwork was done by contract helicopter based at U.S. Geological Survey and Husky Oil field camps and at Naval Arctic Research Laboratory at Barrow. The laboratory has been the base for more than 30

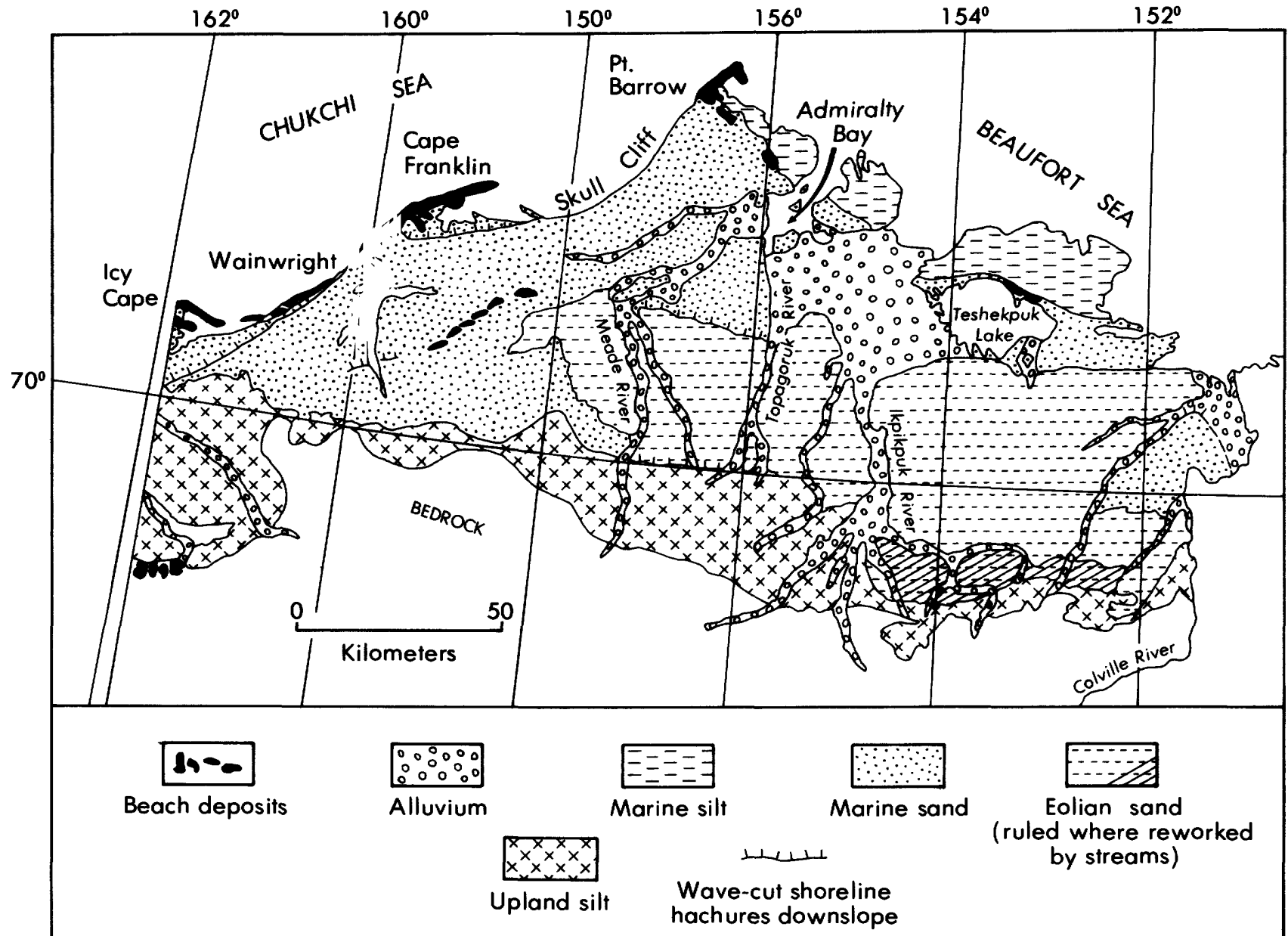

FIGURE 11.-Generalized surficial deposits map of Arctic coastal plain in National Petroleum Reserve in Alaska. 
years of important arctic research, including Quaternary geologic studies by Black (1951, 1964), McCulloch (1967), O'Sullivan (1961), O'Sullivan and Hussey (1960), and Sellmann and Brown (1973). Carson and Hussey $(1960,1962)$ have worked out the origin of oriented lakes and have described processes of thaw collapse and filling by which the landscape is extensively modified. Long-continued activity of these processes largely obscures the initial marine, fluvial, or eolian landforms. This modification, shallow frozen ground, and scarcity of natural exposures make the photointerpretation and field mapping of unconsolidated deposits difficult.

The unconsolidated deposits include Pleistocene and Holocene alluvium of the modern stream valleys and the Pleistocene marine, fluvial, and eolian deposits that blanket the remainder of the coastal plain and constitute the Gubik Formation (Black, 1964; Gryc and others, 1951); they occupy nearly half of the $97,000 \mathrm{~km}$ of the reserve. The southern limit of the coastal plain lies along the zone at which the surficial upland silt (foothill silt of O'Sullivan, 1961) gives way to bedrock and regolith in the uplands (fig. 11). The silt unit overlies a sequence of marine and fluvial deposits that occupy valleys cut in Cretaceous bedrock (O'Sullivan and Hussey, 1960). The gravel mapped (Chapman and Sable, 1960) at an elevation of 120 to $150 \mathrm{~m}$ above sea level near longitude $162^{\circ} \mathrm{W}$ at the upper limit of the upland silt (fig. 11) is probably an ancient beach deposit.

The upland silt is as much as $\mathbf{4 0} \mathrm{m}$ thick, is calcareous, and has a grain-size distribution like that of eolian silt. In local areas, however, the deposit is pebbly and in other places contains thinbedded very fine to fine sand and horizons of felted peat. O'Sullivan and Hussey (1960) argued for a noneolian origin, preferring instead a marine-fluviatile one; however, the position of the silt downwind from extensive sand dunes and its grain size suggest that part may be eolian, and the unit may be polygenetic.

Lower than the upland silt and separated from it by a break in slope that ranges from sharp and straight (wave cut?) to indistinct is a large area of marine sand of nearshore origin in the west and eolian sand in the east. In some areas near its boundary with the upland silt, the eolian sand has been reworked by streams (ruled pattern, fig. 11) and is mantled by about $3 \mathrm{~m}$ of stratified sand containing lenses of detrital twigs. Elsewhere, the eolian sand makes up longitudinal and transverse dunes in an area that is approximately that first mapped by Black (1951). Dune sand is clean and without pebbles; it reaches a thickness of about $30 \mathrm{~m}$ in the center of the sand dune area east of the Ikpikpuk River.

Deposits mapped as nearshore marine sand were probably produced during more than one transgression and consist of clean to silty or clayey, fine to medium sand containing pebbles and granules of chert. In the west these deposits lie on both sides of a wave-cut scarp a short distance inland from the Chukchi Sea coast and on either side of another about $30 \mathrm{~m}$ above sea level. East of the Meade River, the marine sand is separated from eolian sand by a wave-cut scarp, the base of which is 20 to $25 \mathrm{~m}$ above sea level. Still farther east, in the vicinity of the Colville River, the marine sand unit includes areas where the marine deposits have been reworked by streams that crossed the coastal plain before development of the modern stream valleys. The reworked deposits can be distinguished from the marine sand only by detailed field and laboratory studies and, therefore, are not separated on the geologic map.

Fine-grained marine deposits, consisting of silt and clay, lie beneath younger marine deposits at Skull Cliff southwest of Barrow and to the east and southeast as indicated in boreholes and in coastal exposures (Black, 1964). Beach deposits at Barrow can be traced southeastward along the north shore of Teshekpuk Lake where these gravel and sand deposits lie landward of finegrained silt and clay. This shoreline may represent an offshore bar or island complex that perhaps enclosed a lagoon as well as land to the west now filled by deltas (alluvial deposits) of the Ikpikpuk, Topagoruk, and Meade Rivers (fig. 11). Extensive modern gravel beaches are limited to Icy Cape, Cape Franklin, and Point Barrow; elsewhere the coastal beaches are narrow and thin.

At the present time data from our fossil collection and organic samples for age dating have not been received from the laboratory, and much compilation of field data remains. Therefore, discussion of age assignments for these deposits and possible revision of those by Lewellen (1972), McCulloch (1967), Sellmann and Brown (1973), and U.S. Geological Survey (1976) are reserved until the fieldwork is completed. 


\section{REFERENCES CITED}

Black, R. F., 1951, Eolian deposits of Alaska: Arctic, v. 4, no. 2, p. 89-111.

- 1964, Gubik Formation of Quaternary age in northern Alaska: U.S. Geol. Survey Prof. Paper 302-C, p. 5991.

Carson, C. E., and Hussey, K. M., 1960, Hydrodynamics in three Arctic lakes: Jour. Geology, v. 68, p. 585-600. 1962, The oriented lakes of Arctic Alaska: Jour. Geology, v. 70 , no. 4, p. 417-439.

Chapman, R. M., and Sable, E. G., 1960, Geology of the Utukok-Corwin region, northwestern Alaska: U.S. Geol. Survey Prof. Paper 303-C, p. 47-167.

Gryc, George, Patton, W. W., Jr., and Payne, T. G., 1951, Present Cretaceous stratigraphic nomenclature of northern Alaska: Washington Acad. Sci. Jour., v. 41, no. 5, p. 159-167.

Lewellen, R. I., 1972, Studies on the fluvial environment, Arctic Coastal Plain Province, northern Alaska: Littleton, Colorado, 2 volumes, 282 p. (pub. privately).

McCulloch, D. S., 1967, Quaternary geology of the Alaskan shore of the Chukchi Sea, in Hopkins, D. M., ed., The Bering Land Bridge: Stanford Univ. Press. p. 91-120.

O'Sullivan, J. B., 1961, Quaternary geology of the Arctic coastal plain, northern Alaska: Iowa State Univ. Sci. and Tech., Ph.D. thesis $191 \mathrm{p}$.

O'Sullivan, J. B., and Hussey, K. M., 1960, Non-eolian origin for silts of the Arctic Slope [abs.]: Geol. Soc. America Bull., v. 71, no. 12, pt. 2, p. 1940.

Sellmann, P. V., and Brown, Jerry, 1973, Stratigraphy and diagenesis of perennially frozen sediments in the Barrow, Alaska, region, in North American Contribution to 2nd International Permafrost Conference, Yakutsk: Washington, Natl. Acad. Sci., p. 171-181.

U.S. Geological Survey, 1976, Reinterpretation of part of the Gubik Formation, Arctic coastal plain: U.S. Geol. Survey Prof. Paper 1000, p. 83-84.

Williams, J. R., Yeend, W. E., Carter, L. D., and Hamilton, T. D., 1977, Preliminary surficial deposits map, National Petroleum Reserve - Alaska: U.S. Geol. Survey Open-File Report 77-868, 2 sheets.

Studies of proposed airfields at the Inigok and Tunalik well sites, NPRA

By Reuben Kachadoorian, F. E. Crory ${ }^{1}$, and D. L. Berg'

An integral part of the 1977-1978 petroleum exploration program in NPRA is the drilling of two wells to depths of $5,760 \mathrm{~m}$ or more. These deep wells, at Inigok and Tunalik (fig. 12), will take about 13 months to complete and will require construction of temporary airfields that must be operational during summer and winter. The airfields must be capable of handling Hercules (C-130) aircraft, which require runways $50 \mathrm{~m}$ wide and $1,600 \mathrm{~m}$ long.

\footnotetext{
'U.S. Army Cold Regions Research and Engineering Laboratory, Hanover,
} N.H.

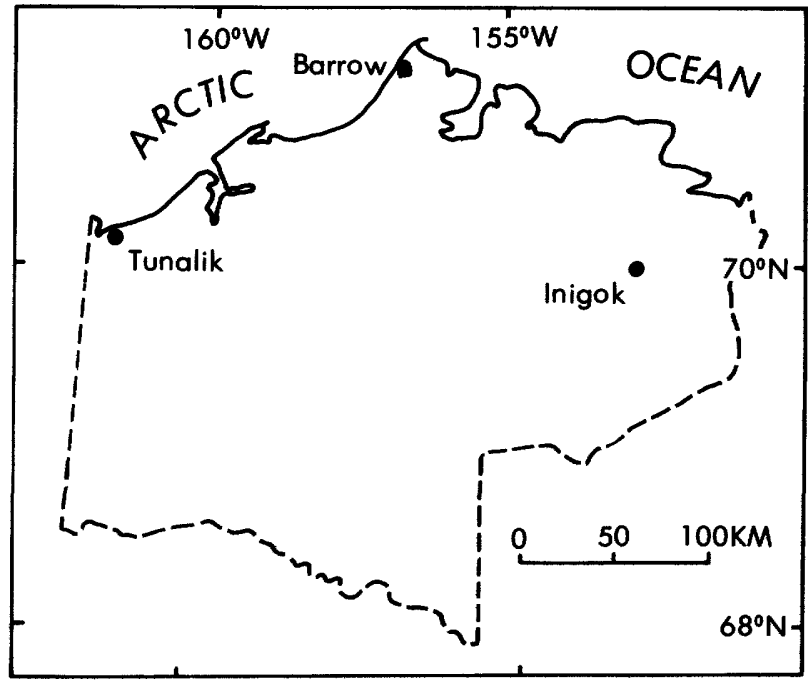

FIGURE 12.-Map of NPRA showing locations of Inigok and Tunalik well sites.

There are several airfields of this size, or smaller, along the northern coast of Alaska, but none, to our knowledge, was constructed in the winter. The Inigok and Tunalik airfields, however, must be constructed in the winter and completed before the end of May 1978, when the spring thaw weakens the ice runways on the nearby lakes. The winter snow roads connecting the lakes and the drill sites will also be unusable after thawing commences.

Field and laboratory studies by the U.S. Geological Survey and the U.S. Army's Cold Regions Research and Engineering Laboratory were made to evaluate the engineering-geologic and permafrost-related conditions to which the airstrips and other structures would be subjected. The field study was directed at evaluating soil and permafrost conditions and locating suitable gravel deposits for the Inigok and Tunalik sites.

The Inigok site is underlain by frozen, silty, fine sand, and the only locally available borrow is a similar material. Sandy gravel, in limited quantities, was located at several sites along Judy Creek, about $24 \mathrm{~km}$ northeast of the proposed Inigok site. These deposits are reworked early Pleistocene marine gravels. A large amount of Holocene gravel was found along the Kikiakrorak River, about $42 \mathrm{~km}$ southeast of Inigok, but its use requires removal of up to $3 \mathrm{~m}$ of frozen overburden. The Kikiakrorak River gravel is predominantly flat or platey and will require crushing to produce a suitable graded gravel for the 
runway. An additional source of Holocene gravel was located by a Husky Oil crew (operation contractor in NPRA) at the confluence of the Colville and Kikiakrorak Rivers, about $58 \mathrm{~km}$ east of the Inigok site. This gravel will also require crushing.

Studies at the Tunalik site indicate that the proposed airstrip will be underlain by silty sand and, locally, up to $1.5 \mathrm{~m}$ of frozen peat. Suitable sand and gravel borrow material was located about $6.5 \mathrm{~km}$ west of the site, and an additional source of sand and gravel was located on a terrace north of the Ongorakvik River, about $10 \mathrm{~km}$ north of the Tunalik site. These deposits occur along a late Pleistocene shoreline of the Arctic Ocean. The sand and gravel north of the Ongorakvik River are reworked late Pleistocene shoreline deposits. The gravel at these sites will not require crushing.

The field studies provided a more complete appreciation of conditions at each site, including the quantity and quality of available construction materials. Subsequent studies concentrated on laboratory testing of the materials and fullscale testing of design options. After standard classification tests were performed on samples of the sand and gravel, a series of compaction tests were conducted to define the optimum water content and density of each soil. The compaction tests were also extended to study the possible range of attainable densities of frozen fine sand placed and compacted at different initial water (ice) contents. These same frozen samples were later thawed and surcharged or otherwise consolidated and wetted to determine the magnitude of settlement associated with thawing. In all tests, the thaw-settlement of the sand when used as a fill was greater than the potential settlement of the same sand in a cut section. This condition is caused by the lower in-place density of the fill section, when compared to the in-situ densities of the same sand in the borrow pit. On the basis of this finding, a design permitting extensive cut sections rather than fill sections was adopted. This procedure contradicts the normal procedure for construction in permafrost. The general preference for fill sections in highway and airfield construction in permafrost areas is based on the greater in-place density of compacted fill sections constructed with thawed soils, as compared to the density of the frozen cut sections. In the two NPRA airfields, however, frozen material must be used in the fill sections as well as the cut sections.

To evaluate the potential of thawed gravel for supporting the aircraft, California Bearing Ratio (CBR) tests were conducted on all gravels and blends of sands and gravels. The potential for using soil-cement to stabilize the sands, particularly if the amount of gravel is limited, was investigated. Three different types of cements were tested at various water contents and soil-cement ratios. The soil-cements were prepared and cured at $4^{\circ} \mathrm{C}$ to simulate possible field conditions. Good to excellent soil-cement could be produced with the Inigok sand, provided the cement content was between 15 and 20 percent and the water content was between 10 and 15 percent. These proportions would require 2,080 to 2,800 tons of cement per $0.1-\mathrm{m}$ depth of the runway.

Other laboratory tests included an investigation of the possible use of salt to aid in thawing and compacting frozen borrow sand and a study to estimate the evaporative loss from the frozen borrow. Results indicated that inordinate amounts of salt would be required and that undesirable thawing of the subgrade would occur after a few years. Substantial sublimation of the sand, however, can be expected and could be advantageously employed to obtain higher degrees of compaction in the upper layers of the subbase.

Calculations were made to estimate the depth of seasonal thawing in different design configurations. Various thicknesses of gravel and combinations of gravel and insulating materials were used in the computations, as were combinations of landing mat over insulation. Insulation was included because it was considered nearly impossible to haul the necessary volume of gravel to prevent thawing into the ice-rich subgrade. The use of landing mat over insulation was considered as an alternative to gravel.

Several design options were tested at the U.S. Army Waterways Experiment Station using sands and gravels similar to those at Inigok. The test sections were trafficked with a device simulating a fully loaded Hercules landing gear. The tests disclosed that the silty sand, when saturatedand thawed, would require considerably more than $50 \mathrm{~cm}$ of gravel surfacing. Test sections of gravel over insulation, on a strong (that is, frozen) subgrade indicated that only 38 to $45 \mathrm{~cm}$ of gravel was required, provided the insulation had 
a compressive strength of $4 \mathrm{~kg} / \mathrm{cm}^{2}$. Landing mat (XM-19) placed directly on this insulation was also tested and found to be satisfactory.

The laboratory and field studies indicated that frozen silty sand can be effectively used as a subgrade for both the Inigok and Tunalik airfields, provided it is kept frozen by sufficient insulation. The wearing surfaces of the runways should be $50 \mathrm{~cm}$ or more of gravel or landing mat paintedwhite. The exposed sandy shoulders of the runways should be stabilized and revegetated to reduce thawing and control erosion.

The construction and performance of the Inigok and Tunalik airfields will be carefully monitored to obtain design, construction, and maintenance data that can be directly applied to the design and construction of future airfields in NPRA .

Granite on the Barrow arch, northeast NPRA By K. J. Bird, C. L. Connor, I. L. Tailleur, M. L. Silberman, and J. L. Christie

Sample examination indicates that the Navy East Teshekpuk well (sec. 1, T. 14 N., R. 4 W.) bottomed in granite. This granite is the first found in the subsurface north of the Brooks Range. Drilling was halted at $3,250 \mathrm{~m}$ after penetrating nearly $305 \mathrm{~m}$ of carbonate strata belonging to the Lisburne Group and about $12 \mathrm{~m}$ of rock described by the well-site geologist as "conglomeratic sandstone." During routine inspection of well cuttings from the "conglomeratic sandstone," Bird noted cuttings with a granitic texture (interlocking crystals) and granitic composition (quartz, feldspar, and biotite). Because granitic rock or granitic debris (conglomerate) has not previously been reported from the subsurface, a more detailed investigation of this interval was undertaken. Samples collected at 3-m intervals were examined under the binocular microscope and in thin section. The cuttings appear to represent the rock being drilled with only minor amounts of contamination from uphole. T'his brief report describes the rocks and their log response for the interval 3,200 to $3,250 \mathrm{~m}$ (fig. 13).

Cuttings from 3,200 to $3,240 \mathrm{~m}$ in the Lisburne Group consist predominantly of sandy, fossiliferous grainstone with minor amounts of oolitic and coated-grain grainstone, calcareous sandstone, wackestone, and secondary chert. The sand in the limestone and calcareous sandstone consists of fine- to very-fine, subrounded grains of quartz

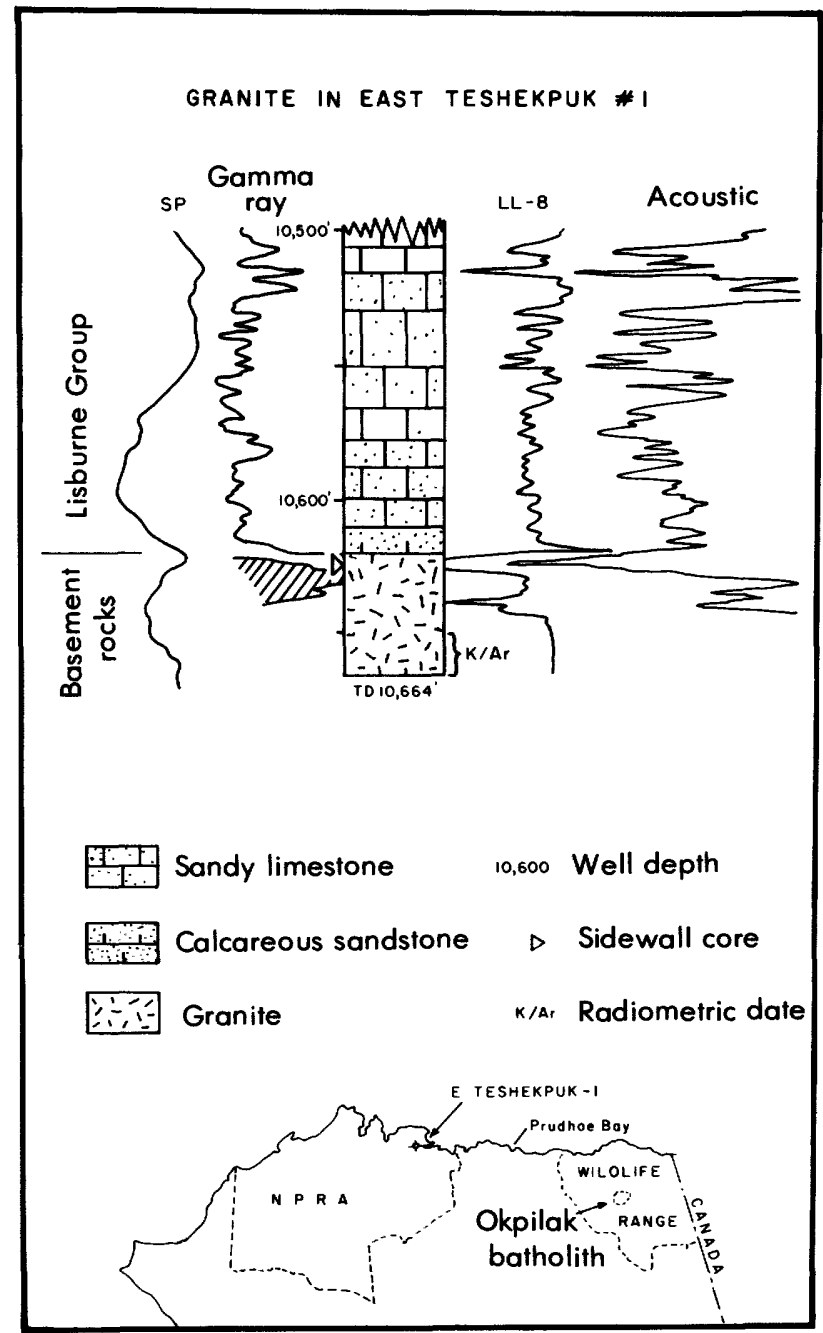

FIGURE 13.-Lithology and wireline log response of granite in East Teshekpuk No. 1.

and chert; approximately 60 percent are quartz. Feldspar grains were specifically searched for, but none were found. The age of these sandy carbonates is Late Mississippian (Chesterian, foraminiferal zones 18-19).

Granitic rock predominates in samples from $3,240 \mathrm{~m}$ to the bottom of the well at $3,250 \mathrm{~m}$. This rock consists of roughly equal amounts of quartz and feldspar with 1 to 5 percent biotite. Cobaltinitrate staining reveals that about 75 percent of the feldspar is potassium feldspar. Crystal size is variable, from 0.1 to $2.0 \mathrm{~mm}$ or more, and shows an interlocking fabric characteristic of an igneous origin. Samples from $3,240 \mathrm{~m}$ and $3,242 \mathrm{~m}$ and a sidewall core from $3,238 \mathrm{~m}$ all show moderate to complete alteration of the feldspar to clay 
minerals and of the biotite to chlorite. Below $3,242 \mathrm{~m}$ the granite is relatively unaltered.

Because of the previous description of this rock as a conglomeratic sandstone, a special effort was made to determine if the cuttings came from granite "wash," a sedimentary deposit, or in=situ granite. Features indicative of a detrital origin that can be observed in cuttings include (1) cuttings with one or more smooth or rounded edges, (2) cuttings with a weathered rind on one edge, (3) rounded, granule- or sand-size granitic fragments, and (4) cuttings showing sand or clayey matrix adhering to the edge of a larger fragment. Because none of these features was observed, it was concluded that the drill penetrated in-situ granite and not a sedimentary deposit.

The contact between the Lisburne Group and the granite appears to be about $3,237 \mathrm{~m}$ on the basis of the prominent deflection of the various well logs at this depth (fig. 13). The contact is probably erosional. No evidence of thermal alteration or unusual mineralization was found in the carbonate rocks that would suggest an intrusive relation. The altered nature of the upper $6-9 \mathrm{~m}$ of granite may indicate a weathered interval below an unconformity; however, no detrital feldspar was observed in the sandstone and sandy limestone overlying the granite.

Results of potassium-argon dating on cuttings from $3,245 \mathrm{~m}$ to $3,250 \mathrm{~m}$ shown below also suggest an erosional, unconformable relation between the Lisburne Group and the granite.

Mineral
Potassium feldspar
Biotite $\ldots \ldots$
$\frac{\text { Age }}{10} \mathrm{~m} . \mathrm{y}$.

The ages of the two minerals are discordant, the feldspar yielding a considerably older age than the chloritized biotite. The feldspar is only slightly perthitic and shows minor to locally moderate sericitic alteration; the biotote is chloritized severely $\left(\mathrm{K}_{2} \mathrm{O}\right.$ content 2.1 percent). Biotite and chloritized biotite in general retain less argon during post-crystallization thermal events than feldspar, but because of the minor alteration of feldspar as well, we consider the ages to be minimum figures. The feldspar age is close to an age of $384 \pm 10 \mathrm{~m}$.y. from hornblende, from the contact aureole of the Okpilak batholith (see fig. 13 for location) (W. P. Brosgé, H. N. Reiser, and M. L. Silberman, unpub. data, 1976); this agreement suggests that an important Devonian intrusive episode in northwestern Yukon (Baadsgaard and others, 1961) persisted westward through the northeast Brooks Range to the subsurface of NPRA.

$\mathrm{X}$-ray fluorescence analyses of cuttings from $3,242 \mathrm{~m}$ to $3,245 \mathrm{~m}$ indicate that the granite has the following composition and is similar in composition to samples of the Okpilak batholith to the east (Sable, 1977, table 9):

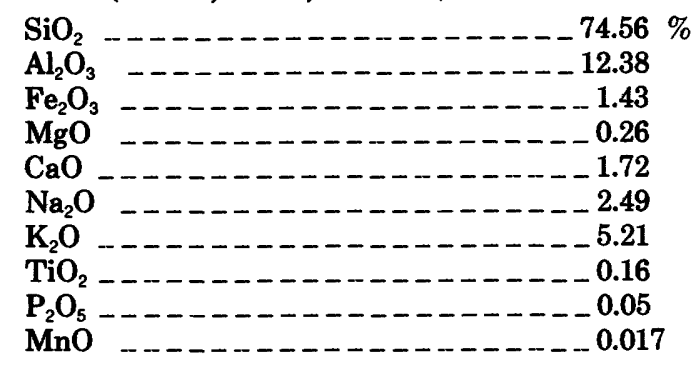

The areal extent of the granite in the East Teshekpuk well may be indicated by gravity data. The most recent Alaska gravity map (Barnes, 1976) shows that the Okpilak batholith is characterized by a prominent gravity low. The well is located on the edge of a gravity low enclosed by the -20 milligal contour. If the granite at East Teshekpuk provides a similar gravity response, then its outline may be described by the gravity low, which is irregularly shaped but generally elongate northwesterly parallel to the Barrow arch.

\section{REFERENCES GITED}

Baadsgaard, H., Folinsbee, R. E., and Lipson, J. I., 1961, Caledonian or Acadian granites of the northern Yukon Territory, p. 458-465, in Raasch, G. D., ed., Geology of the Arctic, Vol. 1: Toronto Univ. Press, 732 p.

Barnes, D., 1976, Bouguer gravity map of Alaska: U.S. Geol. Survey Open-File Report 76-70, 1 sheet, scale 1: $2,500,000$.

Sable, E. G., 1977, Geology of the western Romanzof Mountains, Brooks Range, northeastern Alaska: U.S. Geol. Survey Prof. Paper 897, 84 p.

Organic geochemistry of rocks from three NPRA wells

By Leslie B. Magoon and George E. Claypool

Preliminary results of the study of the NPRA oil and gas source rocks are available for the Topagoruk No. 1, Oumalik No. 1, and South Barrow No. 13 wells. The Topagoruk No. 1 well, located in sec. $25, T .15$ N., R. $16 \mathrm{~W}$., Umiat meridian (UM), was drilled to a total depth of $3,201 \mathrm{~m}$ from June 1950 to September 1951 and was ex- 
tensively cored (Collins, 1958). At a depth of about $1,829 \mathrm{~m}$, slight indications of hydrocarbons were found (Collins, 1958). Analytical work done on some of the cores shows that the section ranges in age from Devonian to middle Cretaceous. The average organic content of the Devonian, Permian, Triassic, and Lower Cretaceous rocks is 1 to 2 weight percent, a surprisingly high value if it is representative of $2,700 \mathrm{~m}$ of section. In the Prudhoe Bay field, Morgridge and Smith (1972) found the Cretaceous section to be richer (5.4 weight percent) and the Permian and Triassic leaner ( 0.7 weight percent); the Devonian section was not analyzed. The organic carbon content of the Jurassic section in the Topagoruk well is 0.5 to 1.0 weight percent, which is less than in the Prudhoe Bay field (1.9 weight percent). The Carboniferous rocks from both areas contain less than 5 percent organic carbon, values too low to be considered an oil source rock. Oil-generating capacity is indicated in these rocks by presence of amorphous and some herbaceous kerogen and by above-average volatile hydrocarbon content, as measured by thermal evolution analysis-flame ionization detection (TEA-FID) (Claypool and Reed, 1976). Evidence for degree of thermal maturity-based on thermal alteration index (TAI), TEA-FID, and vitrinite reflectance-suggests that the rocks are fully mature below $2,438 \mathrm{~m}$. The argillite is probably post-mature (overcooked).

The Oumalik No. 1 well, located in sec. 30 , T. 6 N., R. 16 W., UM, was drilled to a total depth of $3,618 \mathrm{~m}$ from November 1949 to April 1950. The well was extensively cored (Robinson, 1956). At depths from $300 \mathrm{~m}$ to $1,200 \mathrm{~m}$ and at about 3,290 $\mathrm{m}$, slight indications of hydrocarbons were found (Robinson, 1956). This well penetrates a thicker Lower Cretaceous section than Topagoruk No. 1, bottoming in the pebble shale unit at $3,618 \mathrm{~m}$. Organic richness and kerogen composition in the same interval are comparable to that of the Topagoruk well. Depth to maturity, as indicated by vitrinite reflectance, is shallower in the Oumalik well $(2,286 \mathrm{~m})$ than in the Topagoruk well $(2,438$ $\mathrm{m})$, probably as a result of uplift and erosion.

The South Barrow No. 13 well, located in sec. 14, T. 22 N., R. 18 W., UM, was drilled to a total depth of $771 \mathrm{~m}$ from December 1976 to January 1977. Analytical work was done on the canned cuttings acquired at intervals of $15 \mathrm{~m}$, and one $10-3 / 4$ inch casing was set to a depth of $354 \mathrm{~m}$. No indications of hydrocarbons were found in this well. This well penetrates the Lower Cretaceous and Jurassic sections and a thin Triassic unit before bottoming in the argillite. The organic carbon content for Lower Cretaceous rocks is 1 to 2 weight percent, as in the Topagoruk and Oumalik wells. The Oumalik Formation $(<530 \mathrm{~m}$ in Barrow well) and the pebble shale unit (Neocomian in the Barrow well) show, from north to south, increasing organic carbon contents of 1.12 , $1.27,1.35$ and $1.36,1.94,2.15$, respectively. More data and detailed stratigraphic correlations are necessary to evaluate this apparent trend. The organic carbon content of the Jurassic $(0.83$ weight percent) rocks is reasonable when compared to the Jurassic ( 0.66 weight percent) rocks of the Topagoruk well. The values for the Triassic rocks and argillite appear anomalously high. Kerogen is dominantly herbaceous, but the section is probably immature with respect to the temperature history necessary for oil generation. Except for the argillite and an anomalous shallow $(338 \mathrm{~m})$ sample, vitrinite reflectance values are 0.4 or less.

\section{REFERENCES CITED}

Claypool, G. E., and Reed, P. R., 1976, Thermal-analysis technique for source-rock evaluation; quantitative estimate of organic richness and effects of lithologic variation: Am. Assoc. Petroleum Geologists Bull., v. 60, no. 4, p. 608-612.

Collins, F. R., 1958, Test wells, Topagoruk area, Alaska, in Exploration of Naval Petroleum Reserve No. 4 and adjacent areas, northern Alaska, 1944-53, Part 5, Subsurface geology and engineering data: U.S. Geol. Survey Prof. Paper 305-D, p. 265-316.

Morgridge, D. L., and Smith, W. B., 1972, Geology and discovery of Prudhoe Bay field, eastern Arctic Slope, Alaska, in King, R. E., ed., 1972, Stratigraphic oil and gas fields: Am. Assoc. Petroleum Geologists Mem. 16, p. 489-501.

Robinson, F. M., 1956, Core tests and test wells, Oumalik area, Alaska, in Exploration of Naval Petroleum Reserve No. 4 and adjacent areas, northern Alaska, 194453, Part 5, Subsurface geology and engineering data: U.S. Geol. Survey Prof. Paper 305-A, p. 1-70.

\section{Release of NPRA (NPR-4) data} By Robert D. Carter

The Naval Petroleum Reserves Production Act of 1976 transferred jurisdiction over Naval Petroleum Reserve No. 4 from the Department of the Navy to the Department of the Interior effective June 1, 1977. Shortly after the act was signed by the President on April 5, 1976, prep- 
arations were made by the Geological Survey to receive voluminous Navy files accumulated during nearly 50 years of custodianship of the reserve.

During 1977 more than 100 boxes of file material from Washington, D.C.; NPR-1, Elk Hills, California; Anchorage, Alaska; and Barrow, Alaska, were received in Menlo Park. A memorandum from the Deputy Solicitor, Department of the Interior, advised the Geological Survey in June, 1977, that information acquired under the exploration program for the National Petroleum Reserve in Alaska was to be made available to the public under the Freedom of Information Act. As a result of this opinion, an agreement was reached with the Environmental Data Service of the National Oceanic and Atmospheric Administration (NOAA) in Boulder, Colorado, to advertise, reproduce, and disseminate the geologic and geophysical data to the public.

Consequently, material pertinent to the petroleum exploration of the reserve since the completion of the Pet-4 program (1944-1953) was extracted from the files and sent to Houston for integration with data gathered during the Navy's exploration program which was begun in 1974 . Every effort was made to obtain the best possible records for reproduction-such as original well reports, log films. Copies of these data will be sent to NOAA in Boulder. Information on the eight wildcat wells drilled in the northeast part of the reserve will be released first, followed by South Barrow wells 6 through 14, and then by the seismic data in year-by-year packages. The initial release should be available early in 1978 .

Fossil reconnaissance study, eastern NPRA

\section{By Charles A. Repenning}

During four days in August 1977, a trial reconnaissance to evaluate the fossil potential of eastern NPRA was conducted by Repenning, Louie Marincovich, and Robert A. Spicer. Bob Detterman served as guide to the geology and geography.

At Ocean Point, along the lower Colville River on the north slope of Alaska (fig. 2, area 4), Marincovich made a large collection of mollusks in the top of a unit that has been mapped as the Schrader Bluff Formation. The fauna is late Tertiary in age and is also exclusively of "Atlantic" origin, predating the opening of Bering Strait possibly some 3 million years ago. Middle or late
Miocene Atlantic mollusks are known from Carter Creek, $240 \mathrm{~km}$ east of Ocean Point, but the fauna there differs from that at Ocean Point and could be of a different age. Much study remains to be done before a reasonable age can be inferred for the Ocean Point material, but it will have a direct bearing on the time of the connection of the Arctic and Pacific Oceans. The large collection promises to be a cornerstone for future studies of the little known Neogene molluscan paleontology of the Arctic Ocean.

The collared lemming inhabits holarctic tundra. Generally speaking, one species is common to Eurasia and North America west of Hudson Bay. A different species, generally thought to be a primitive relic, lives east of Hudson Bay on the Ungava Peninsula; fossil forms similar to the Ungava collared lemming are known from the early Pleistocene of Eurasia and from the late Pleistocene of Pennsylvania, at the southern limit of Wisconsin Glaciation. Fossils of the more widespread species are known from the late Pleistocene of Eurasia, Alaska, and western Canada and have been found in Wyoming at the southern limit of the glaciation. Two years ago Agadjanian (1976) predicted that the Ungava collared lemming must once have lived in Alaska, although no fossils had been found there. During the fourday reconnaissance, Repenning found a specimen of the Ungava lemming in the upper part of the Gubik Formation, also at Ocean Point. Additional work on the fossil lemming is needed to determine its age significance in Alaska, although it would certainly seem to be pre-Wisconsin. Its presence as a fossil in Alaska strongly supports the interpretation that the living species of the Ungava Peninsula is a relic.

A new Late Cretaceous flora was found much farther down section in the Prince Creek Formation (fig. 2, area 5) that has not yet been studied by Spicer. In the four days of fieldwork, however, nothing was learned of the Cretaceous-Tertiary boundary which may be within the Prince Creek Formation and the marine Schrader Bluff Formation; the Schrader Bluff intertongues with the upper part of the Prince Creek.

\section{REFERENCE CITED}

Agadjanian, Aleaxander, von, 1976, Die Entwicklung der Lemminge der zentralen und östlichen Paläarktis im Pleistozän: Mitt. Bayer. Staatssamml. Paläont. hist. Geol., v. 16, p. 53-64. 
Reconnaissance snow survey of NPRA, April 1977 By Charles Sloan, Dennis Trabant, and William Glude

A reconnaissance snow survey of NPRA was made in April 1977 to ascertain general snow characteristics and distribution patterns. Thirty-nine localities were sampled to determine snow depth, density, and basal snow pack temperature.

Snow cover in April was thin, wind packed, and relatively continuous. Depth and water content generally increased with altitude and distance from the coastal plain.

Snow depth ranged from less than $200 \mathrm{~mm}$ near the coast to nearly $800 \mathrm{~mm}$ in the Brooks Range near Howard Pass. Snow density was relatively high (greater than $0.35 \mathrm{~kg} / \mathrm{L}$ ) in the coastal areas where a wind crust was developed and lower (less than $0.25 \mathrm{~kg} / \mathrm{L}$ ) inland from the coastal plain where there was less wind crust. Snow density was intermediate (about $0.30 \mathrm{~kg} / \mathrm{L}$ ) where the snow depth was greatest. Average snow density for the area was about $0.29 \mathrm{~kg} / \mathrm{L}$. Water equivalent of the snow pack ranged from less than $100 \mathrm{~mm}$ in the coastal areas to more than $250 \mathrm{~mm}$ in the Brooks Range and averaged nearly $130 \mathrm{~mm}$ for the entire area.

Basal snow pack temperatures ranged from about $-20^{\circ} \mathrm{C}$ on the coastal plain, where the snow pack was thin and ambient air temperatures were low, to about $-5^{\circ} \mathrm{C}$ in the foothills where the snow pack was thicker and ambient temperatures higher.

Hydrologic reconnaissance of lakes in NPRA, 1977 By Charles E. Sloan and Richard F. Snyder

A reconnaissance study of lakes was made in NPRA from June to August 1977 using a helicopter on floats. Data were gathered from 202 lakes.

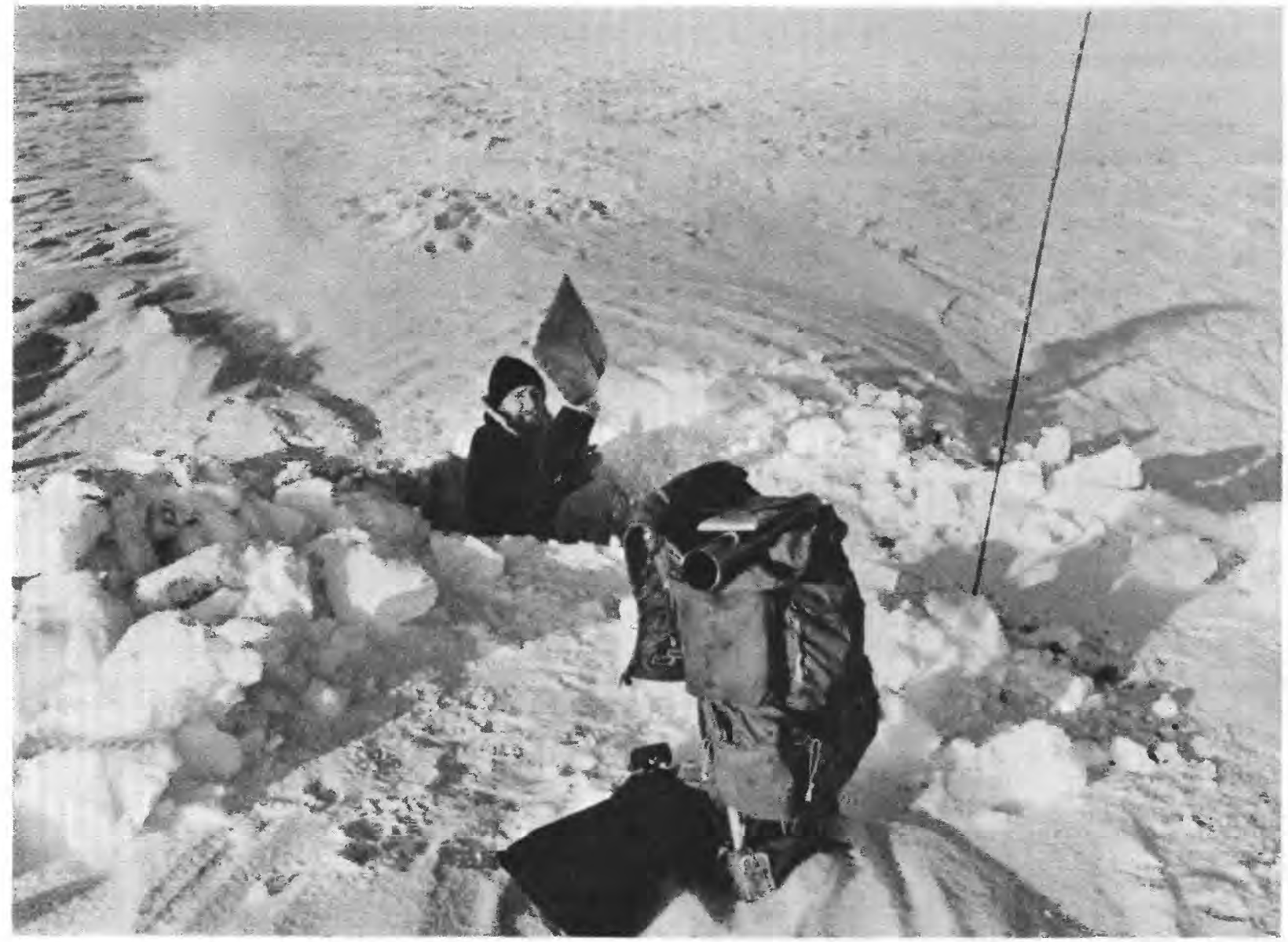

FIGURE 14.-Snow density sampling, western NPRA, April 1977. 
Field measurements were made of depth, water temperature, specific conductance, $\mathrm{pH}$, bicarbonate, secchi depth, color, and turbidity. A bottom grab sample was taken and preserved, and the existence of an inlet or outlet noted. Water samples were taken from selected lakes to determine algae growth potential, total organic carbon, and dissolved inorganic constituents.

Lakes are the most conspicuous hydrologic feature in NPRA, covering 20 to 40 percent of the surface area of the coastal plain. Most of the lakes are less than about $2 \mathrm{~m}$ deep and freeze to the bottom in winter. Teshekpuk Lake, covering about $816 \mathrm{~km}^{2}$, is the third largest lake in Alaska and is about $6 \mathrm{~m}$ deep over most of its basin. Most of the deeper lakes in the reserve are in the hummocky eolian terrain on the coastal plain south of Teshekpuk Lake. A number of these lakes are in the 50 -foot $(15 \mathrm{~m})$ class, and some approach $20 \mathrm{~m}$ in depth. Glacial lakes in the Brooks Range are relatively deep, as much as 37 $m$ in NPRA.

Most of the lakes in NPRA have very low specific conductance; exceptions are those near the coast that have direct tidal connection to the sea or have been contaminated by sea water from storm surges. Lakes that freeze to the bottom are shallow enough that wind effects can stir the bottom sediment and produce turbid water. The lakes with the greatest turbidity are the shallow coastal plain lakes from Barrow to the Colville Delta that are underlain by marine silt. Lakes of similar depth underlain by sand are much less turbid.

Streamflow in NPRA, 1977

By S. H. Jones

Streamflow of selected streams in NPRA was studied by reconnaissance methods during June, July, and August 1977. The survey made during June and July measured discharge and collected water-quality samples during low-flow conditions. Streamflow records were collected on the Colville, Meade, and Miguakiak Rivers, and Nunavak Creek from June to September to determine runoff characteristics of water quality and suspended sediment.

Estimates of maximum evident flood-peak discharges were made for 10 streams on the basis of field evidence. Maximum evident flood-peak discharge rates range from $0.08 \mathrm{~m}^{3} / \mathrm{s} / \mathrm{km}^{2}$ of drainage area to $0.88 \mathrm{~m}^{3} / \mathrm{s} / \mathrm{km}^{2}$ of drainage area for large drainages in NPRA. The primary causes of floods in the study area are rapid spring snowmelt and summer or fall rainstorms. Spring breakup flooding was significantly increased on the Colville and Meade Rivers by the presence of ice jams. Low-gradient stream systems such as the Miguakiak River and Teshekpuk Lake are flooded by the upstream flow of the Ikpikpuk River. Winds can cause rapid increases in stage and discharge on the Miguakiak River. Persistent high flow occurs in basins with large or numerous lakes where the streams are adequately supplied with water from lake storage.

Low or no flow was observed during the period of below-normal precipitation from June through August 1977 in several rivers in NPRA. Runoff for the water year 1977 for the Nunavak Creek, for example, was about 50 percent below the annual discharge for six years of record. About 80 percent of the runoff occurs during snowmelt on this small stream draining the coastal plain.

Development and operation of gas fields in the South Barrow area

By Robert D. Carter and Robert J. Lantz

Responsibility for supplying gas to the Point Barrow area passed to the Department of the Interior and the Geological Survey on June 1, 1977. The task is twofold: to continue development and operation of the South Barrow field, and to find new gas reserves.

An inspection trip to the field and reference to engineering reports (H. J. Gruy and Associates, Inc., 1976; Husky Oil NPR Operations, Inc., internal memo., 1976) revealed a need for additional wells, extensive workovers of existing wells, and upgrading of the gas gathering, metering, and transmission systems. Negotiations are presently being conducted with the Navy Facilities Command concerning detailed mapping of these systems so that remedial action can be taken.

Well drilling at present emphasizes exploring and developing new gas reserves so that the South Barrow field can be shut-in, analyzed in detail, and then developed for maximum deliverability. One exploratory well and two eastern area confirmation well sites, to be drilled in 1978 , were chosen on the basis of recent geologic and geophysical data. Detailed plans for the drilling, coring, and testing of these wells were written 
with particular emphasis on gathering information leading to more accurate estimates of reserves and well deliverability. A supplementary reservoir engineering study will provide recommendations in this regard. The Navy Facilities Command is also being asked to consider the construction of a road and pipeline from the eastern wells to the Point Barrow area. Special geophysical studies are underway to identify reservoir beds and to trace their structural attitudes and possible facies changes.

\section{REFERENCE CITED}

Gruy, H. J., and Associates, Inc., 1976, Reservoir engineering and geologic study of the South Barrow gas field, Naval Petroleum Reserve No. 4, Alaska: Report prepared for U.S. Navy, 16 p.

A simple target model for offshore permafrost at Prudhoe Bay

By Arthur H. Lachenbruch and B. Vaughn Marshall

Because of the importance of ice-bonded subsea permafrost in engineering problems related to the exploitation of offshore oil and gas, it is useful to consider a highly idealized preliminary model of the gross features of Prudhoe Bay permafrost. Although it will certainly be wrong in detail, the model should serve to focus attention on the sensitive parameters and provide some guiding context for future work. It is a target model in the sense that it gives us something to "shoot" at.

The model is represented schematically in figure 15. At the time of submergence, the temperature is given by the curve $t=0$; thereafter the sea bottom is maintained at temperature $\Theta_{0}$, and the melting (and freezing) temperature of interstitial ice is maintained at $\Theta_{\mathrm{f}}$ at the upper surface and $\Theta_{f}^{\prime}$ at the lower surface of the ice-bonded permafrost. We shall assume that $\Theta_{\mathrm{o}}$ and $\Theta_{\mathrm{f}}$ have remained constant at their presently observed values since some effective date of submergence $t=0$. This constancy, of course, cannot be true, but the assumption is justified by the resulting simplicity of the analysis and by our present ignorance of the time-dependence of these quantities. Figure 15a represents the case $\Theta_{0}>\Theta_{f}$ which results in a thawed layer at the sea bed, and figure $15 \mathrm{~b}$ represents $\Theta_{\mathrm{o}}<\theta_{\mathrm{f}}$ where there is only superficial thawing, resulting largely from seasonal effects. This model is one-dimensional, that is, we neglect horizontal transfer of heat, treating the submergence as if it were a sudden climatic change. For slow transgression and at points close to the shoreline, this assumption must be examined carefully. We assume further that essentially all the latent heat is released over a very small temperature interval, effectively at $\Theta_{\mathrm{f}}$ near the top of the ice-bonded permafrost, and at $\Theta_{f}^{\prime}$ near the bottom of permafrost. We assume also that prior to submergence, a thermal steady state had been established on land, the geothermal flux is constant, and that the thermal properties of the frozen and thawed materials and the moisture content are uniform. These assumptions are reasonably consistent with subsurface observations on land near Prudhoe Bay (Gold and Lachenbruch, 1973). We have chosen parametric values consistent with the fragmentary observational evidence presently available; no great precision should be attached to the numerical results.

The analysis (Lachenbruch and Marshall, 1977), based on heat-conduction theory, underscores the importance of distinguishing between the two cases, $\Theta_{\mathrm{o}}>\Theta_{\mathrm{f}}$ (fig. 15a) and $\Theta_{\mathrm{o}}<\Theta_{\mathrm{f}}$ (fig. $15 \mathrm{~b})$. In the first case $\left(\Theta_{0}>\Theta_{\mathrm{f}}\right)$, permafrost thaws downward progressively from the sea bed and eventually disappears. In the second case $\left(_{0}\right.$ $<\Theta_{\mathrm{f}}$ ), permafrost persists near the sea bed, even in the steady state. The second case is expected in a near-shore band where sea-ice freezes to the bottom seasonally, but it is also possible at offshore locations. $\Theta_{0}$ depends on the seasonal regime of the sea water, and $\Theta_{\mathrm{f}}$ depends upon salt transport mechanisms in the sea bed; small changes in the relative values of $\Theta_{0}$ and $\Theta_{f}$ can change the sign of their difference and convert one regime to the other. Several aspects of this problem have been discussed in detail by Harrison and Osterkamp (1976) and Osterkamp (1975).

When the cold permafrost is inundated by the sea, it absorbs heat from the relatively warm sea bed above and from geothermal flux rising from below. After an initial period (about 1,800 years for Prudhoe Bay), temperatures in the icebonded permafrost become nearly uniform at the value determined by the melting temperatures of its upper and lower surfaces (for example, curve $t_{3}$, fig. 15a). A substantial amount of the heat conducted downward through the sea bed is consumed in warming the permafrost to its melting temperature (not melting it) in the initial phases. 


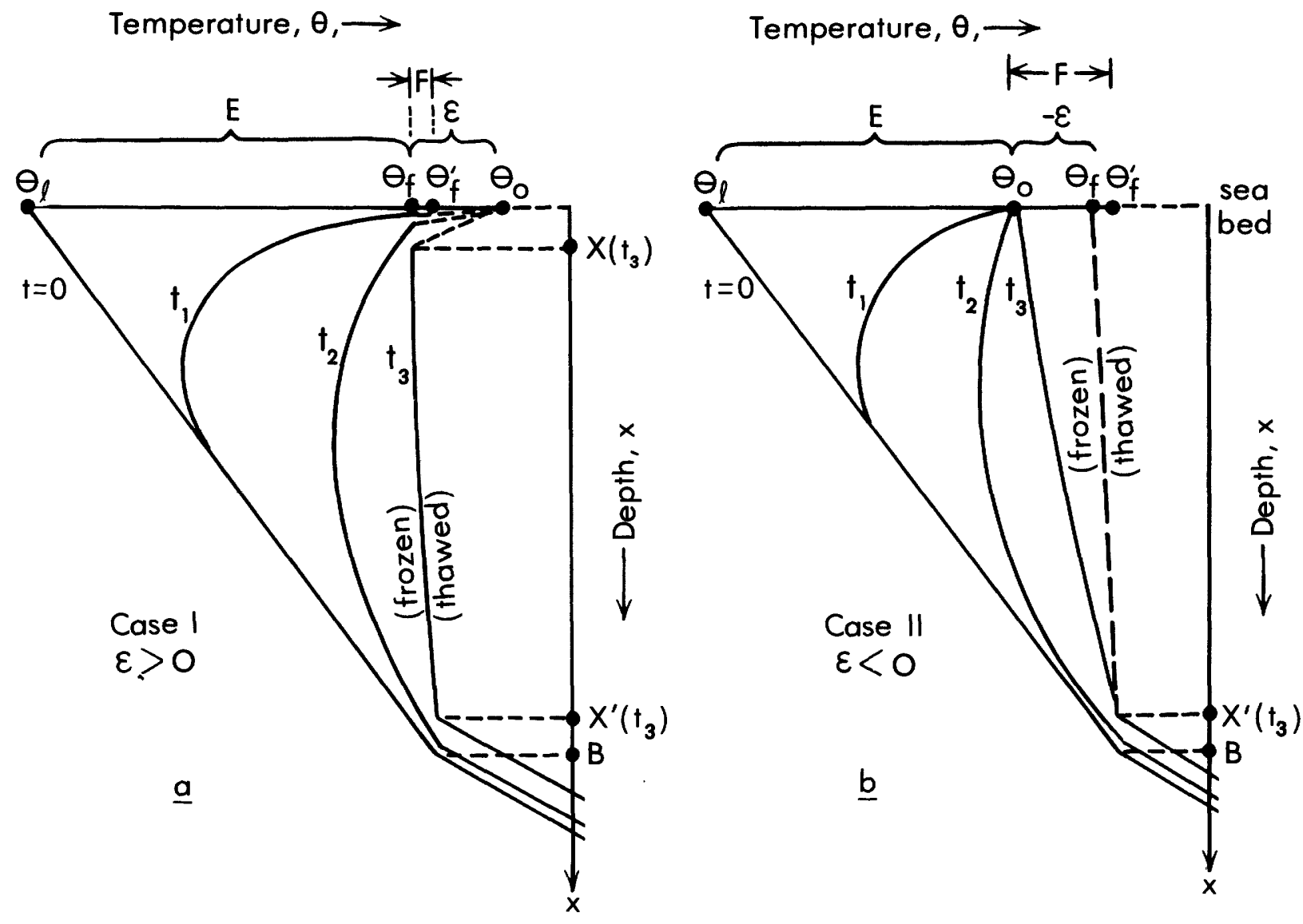

FIGURE 15.-Schematic representation of sub-sea temperatures at successive times $t=0, t_{1}, t_{2}$, $t_{3}$, following submergence of a region underlain by ice-rich permafrost. a. Mean sea-bed temperature, $\Theta_{0}$, greater than melting temperature, $\Theta_{\mathrm{f}}$, at top, $\mathrm{X}(\mathrm{t})$, of permafrost. b. Mean sea-bed temperature, $\Theta_{\mathrm{o}}$, less than melting temperature, $\Theta_{\mathrm{f}}$, at top of permafrost.

For conditions at Prudhoe Bay, the total amount of this heat is equivalent to that required to melt 25-30 $\mathrm{m}$ of ice-bonded permafrost. One-third of the heat required to deplete the initial subfreezing cold reserve of permafrost is supplied by geothermal flux entering through the lower boundary; for conditions at Prudhoe Bay the lower surface of permafrost rises only about $7 \mathrm{~m}$ during the first 1,800 years, and thereafter it rises at the near-constant rate of about $12 \mathrm{~m}$ per thousand years. Under conditions of figure 15a $\left(\Theta_{0}>\Theta_{f}\right)$, the rate of thawing of the upper surface of ice-bonded permafrost diminishes progressively with time because the thickness of the insulating thawed layer increases. The model applied to thermal observations in the sea bed implies that the present rate of thawing of the upper surface of ice-bonded permafrost is about $1 \mathrm{~cm} / \mathrm{yr}$ or less. Hence permafrost is probably degrading faster at its lower surface than at its up- per surface, and this disparity in thawing rates can be expected to increase with time.

A literal interpretation of the model suggests that ice-bonded permafrost might extend to depths of $500 \mathrm{~m}$ within 15 to $20 \mathrm{~km}$ of the shureline at Prudhoe Bay today. The model can be refined, revised, or superseded by data acquired from a few offshore holes to depths of $100 \mathrm{~m}$ in selected localities.

\section{REFERENCES CITED}

Gold, L. W., and Lachenbruch, A. H., 1973, Thermal conditions in permafrost-A review of North American Literature, in Permafrost-The North American contribution to the second International Conference: Washington, D.C., Natl. Acad. Sci., p. 3-23.

Harrison, W. D., and Osterkamp, T. E., 1976, A coupled heat and salt transport model for sub-sea permafrost: Alaska Univ. Geophys. Inst. Rept. UAG R-247, 21 p.

Lachenbruch, A. H., and Marshall, B. V., 1977, Sub-sea temperatures and a simple tentative model for offshore per- 
mafrost at Prudhoe Bay, Alaska: U.S. Geol. Survey Open-File Report 77-395, 54 p.

Osterkamp, T. E., 1975, A conceptual model of offshore permafrost: Alaska Univ. Geophys. Inst. Rept. UAG R-234.

Geophysical profiles through the ShaviovikEchooka River region

By Dennis Giovannetti and K. J. Bird

Gravity and magnetic data were collected along a northwest-trending $66-\mathrm{km}$-long profile that crosses the southern foothills and northern Brooks Range, northeastern Alaska. These data are to be used in making depth-to-basement calculations in this area to aid in structural interpretations. The gravity and magnetic work in the Shaviovik-Echooka River area is part of a program of geologic and geophysical studies directed toward further understanding the stratigraphy, tectonic style, and petroleum potential of the region. This area was chosen for study because of the variety of data available. Future phases of the study will incorporate the following data: (1) surface mapping, (2) U.S. Navy seismic records, (3) well logs and drill cuttings from four wells, (4) low-angle aerial photographs obtained from Standard Oil of California (Reber, 1976), and (5) measured outcrop sections.

Ground magnetic and gravity readings (.8- to $2.5-\mathrm{km}$ station spacing) were used to construct total intensity magnetic and Bouger anomaly profiles. These profiles and their relation to major stratigraphic and physiographic boundaries are shown in figure 16. Regional fields have not been removed from the data. The regional magnetic gradient in this area decreases in a southwesterly direction according to Woolson (1962, pl. 3). Two short offsets perpendicular to our line of traverse show a pronounced gradient (3-5 gammas $/ \mathrm{km}$ ) decreasing to the southwest, in apparent agreement with the regional map. The Bouger gravity map of Alaska (Barnes, 1976) shows that the regional gradient in this area decreases southeasterly, in the same direction as our profile. Although analysis of the data is still incomplete, inspection of the profiles shows little response to the outcropping basement rocks and few significant anomalies elsewhere.

An 8 milligal gravity low is coincident with a syncline, mapped by Keller, Morris, and Detterman (1961) beneath the Fin Creek well. Cretaceous sedimentary rocks (density $=2.65-2.55$ $\mathrm{g} / \mathrm{cc}$ ) are exposed to the north and south of the syncline, and Tertiary sedimentary rocks (density $=2.39 \mathrm{~g} / \mathrm{cc}$ ) are exposed in the synclinal trough. Low-amplitude anomalies are characteristic of the gravity profile south of the syncline. These anomalies may be related to geologic structure, although they are about the same
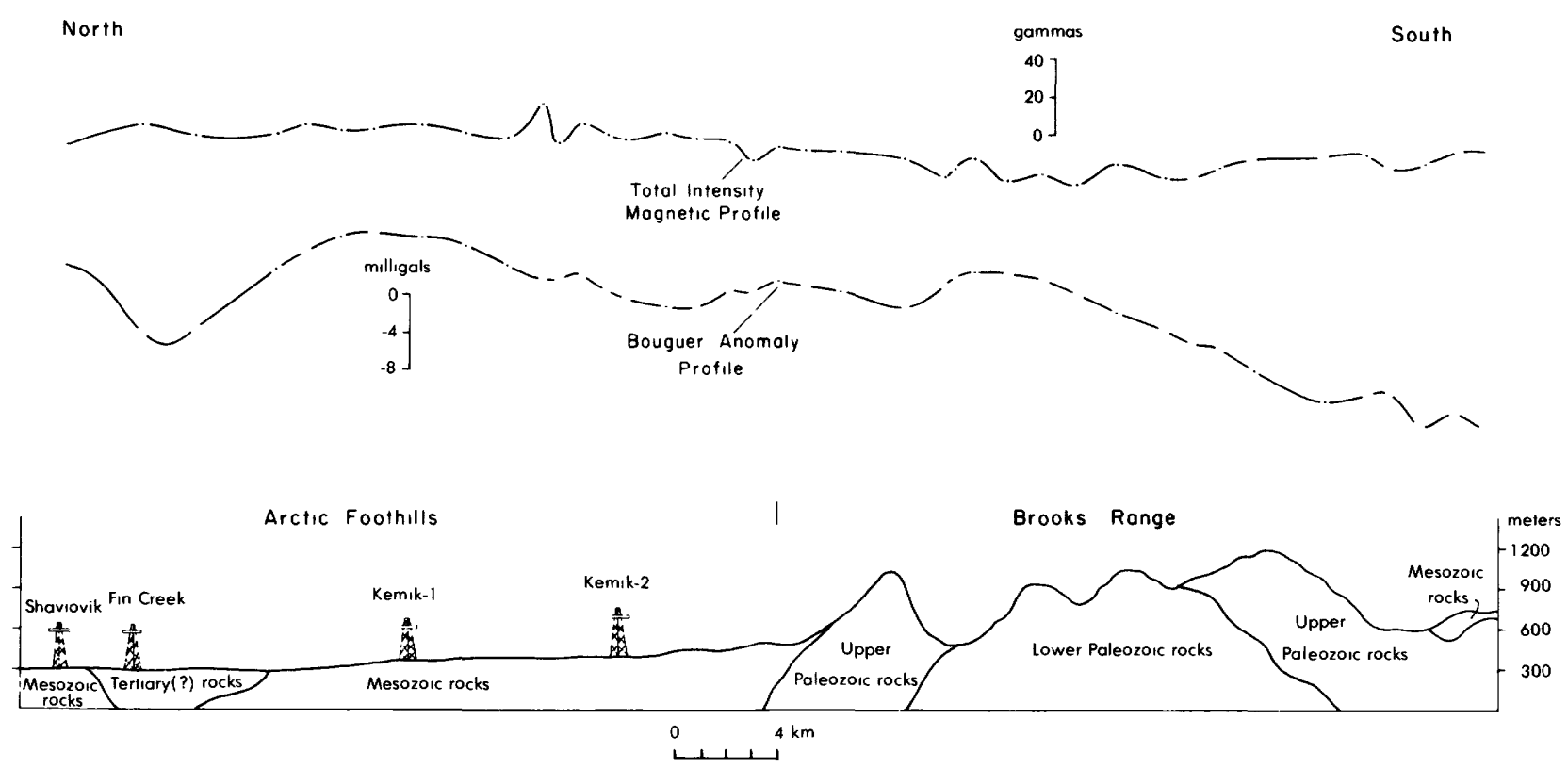

FIGURE 16.-Gravity and magnetic profiles across the northeastern Brooks Range front. Geologic structure, shown diagrammatically here, is the subject for further study. Vertical exaggeration about $5 \times$. 
magnitude as possible gravity errors caused by elevation inaccuracies. Confidence in correlation of these anomalies with geologic features will depend on comparison with an updated geologic map now in progress. Density measurements of selected outcrop samples indicate small density contrasts of $0.07-0.03 \mathrm{~g} / \mathrm{cc}$ between basement metasedimentary rocks and the overlying Mississippian clastic and carbonate rocks. Larger contrasts exist higher in the section.

The nearly flat character of the magnetic profile may indicate that the basement and overlying sedimentary rocks are nonmagnetic to slightly magnetic, or that there is a lack of significant susceptibility contrast along the length of the traverse, or a combination of the two. The nonmagnetic character of the rocks is supported by low susceptibility measurements of 26 samples from lower Paleozoic, upper Paleozoic, and Mesozoic basement rocks. Only one sample, a mafic intrusive rock collected $41 \mathrm{~km}$ southwest of the profile, was magnetic enough to give a quantitatively reliable measurement; a value of 1,426 $\times 10^{-6} \mathrm{cgs}$ was measured using a superconducting susceptometer. Other samples gave questionable results of up to $60 \times 10^{-6} \mathrm{cgs}$, all of which are considered weakly magnetic to nonmagnetic. There appear to be no obvious correlations of the low-amplitude magnetic anomalies (5 to 20 gammas) with geologic features along the profile. Moderately magnetic intrusive rocks are associated with upper Paleozoic carbonate rocks at Flood Creek, $41 \mathrm{~km}$ to the southwest, but the absence of a significant anomaly along the eastward projection of these rocks implies their absence or alteration to nonmagnetic minerals. Aeromagnetic profiles east of the Shaviovik-Echooka River area indicate a 30 - to 40-gamma anomaly coincident with the Brooks Range front. Pre-Mississippian mafic extrusive and intrusive rocks in a west-trending belt have been interpreted to be the source (Brosgé and others, 1970). Well data (Kemik-2) indicate that the basement rocks are deeper than 2,774 $\mathrm{m}$ just north of the Brooks Range front. If the mafic belt extends to the Shaviovik-Echooka area, at a depth of about 3,125 $\mathrm{m}$, a 7 - to 15-gamma anomaly might be expected between Kemik-2 and Brooks Range front. No anomaly of significant amplitude and width to suggest a source depth of $3,125 \mathrm{~m}$ is observed. The west-trending mafic belt either does not extend into the Shaviovik-Echooka area or is too deep to be detected by ground magnetic observations. The small but sharp 20 -gamma anomaly observed between Kemik-1 and Kemik-2 has a source depth of $1,800 \mathrm{~m}$ or less and is within the Mesozoic sedimentary section. It may be caused by pyroclastic sedimentary rocks logged between 609 and $820 \mathrm{~m}$ in Kemik-1.

\section{REFERENCES CITED}

Barnes, D. F., 1976, Bouger gravity map of Alaska: U.S. Geol. Survey Open-File Report 76-70, 1 sheet, scale $1: 2,500,000$.

Brosgé, W. P., Brabb, E. E., and King, E. R., 1970, Geologic interpretation of reconnaissance aeromagnetic survey of northeastern Alaska: U.S. Geol. Survey Bull. 1271-F, 14 p.

Keller, A. S., Morris, R. H., and Detterman, R. L., 1961, Geology of the Shaviovik and Sagavanirktok Rivers region, Alaska: U.S. Geol. Survey Prof. Paper 303-D, p. 171221.

Reber, S. J., 1976, Use of IR color photographs and canyon photos in photogeologic mapping, Central Brooks Range, Alaska: Am. Assoc. Petroleum Geologists Bull., v. 60 , no. 12 , p. 2188.

Woolson, J. R., 1962, Exploration of Naval Petroleum Reserve No. 4 and adjacent areas, northern Alaska, 194453, pt. 4, Geophysics: U.S. Geol. Survey Prof. Paper 304A, 25 p. [1963].

Hydrology of arctic Alaska

By J. M. Childers, D. Kernodle, and R. Loeffler

A reconnaissance of streams in western arctic Alaska in August 1977 completed a project begun in 1975 to study the water resources of arctic Alaska. Surveys were made at 55 sites mostly on larger streams draining the Brooks Range. Indirect measurements of maximum evident flood and bankfull discharge were computed from surveys of channel geometry and high water marks. Results of the flood surveys indicate that maximum evident flood-peak discharges were under 1 $\mathrm{m}^{3} / \mathrm{s} / \mathrm{km}^{2}$ for streams with drainage areas less than $3,000 \mathrm{~km}^{2}$ and were under $0.5 \mathrm{~m}^{3} / \mathrm{s} / \mathrm{km}^{2}$ for streams with drainage areas greater than 3,000 $\mathrm{km}^{2}$. Bankfull discharge generally exceeded 50 year flood estimates made using relations developed from Alaska stream-gaging records and multiple regression analysis of drainage basin characteristics. Land along rivers is attractive for transportation routes and communities, but floods are important hazards to be considered for planning development on potential floodways. A general lack of flood and climatic records in northern Alaska leaves little alternative except 
channel flood evidence for assessing the flood hazard. The flood hazard is complicated by the effects associated with ice, permafrost, and channel erosion and deposition.

Surveys were made at 29 sites on streams, springs, and lakes during April 1976 - a time of annual low flow in the Arctic. The surveys were made to measure streamflow, lake depth, and water quality. Springs were located from large icings sometimes visible on Landsat imagery. Sites on rivers were chosen at large bends or confluences where greater depths are usual. Sites on lakes were chosen near mid-lake where greater depths were considered likely. Radar fixes were often helpful in locating position of the helicopter on almost featureless coastal plain. The surveys indicate the existence of some springs along the south slope of the Brooks Range and east of Umiat along the North Slope. Except for Kav- rorak Spring, with 1,500 microsiemens specific conductance, all springs sampled were of good drinking water quality. From Point Hope to the Canning River no rivers were found with measurable discharge. Through over $2 \mathrm{~m}$ of ice, deeper holes in stream and lakes contained liquid water with water quality varying from good for drinking to objectionable in taste, odor, and color.

\section{EAST-CENTRAL ALASKA}

Late Paleozoic radiolarians and conodonts found in chert of Big Delta quadrangle

By H. L. Foster, D. L. Jones, T. E. C. Keith, Bruce Wardlaw, and F. R. Weber

Late Paleozoic radiolarians and conodonts have been found at one locality in red chert associated with green and gray chert in the Big Delta D-1 quadrangle, Alaska (see fig. 18). These are

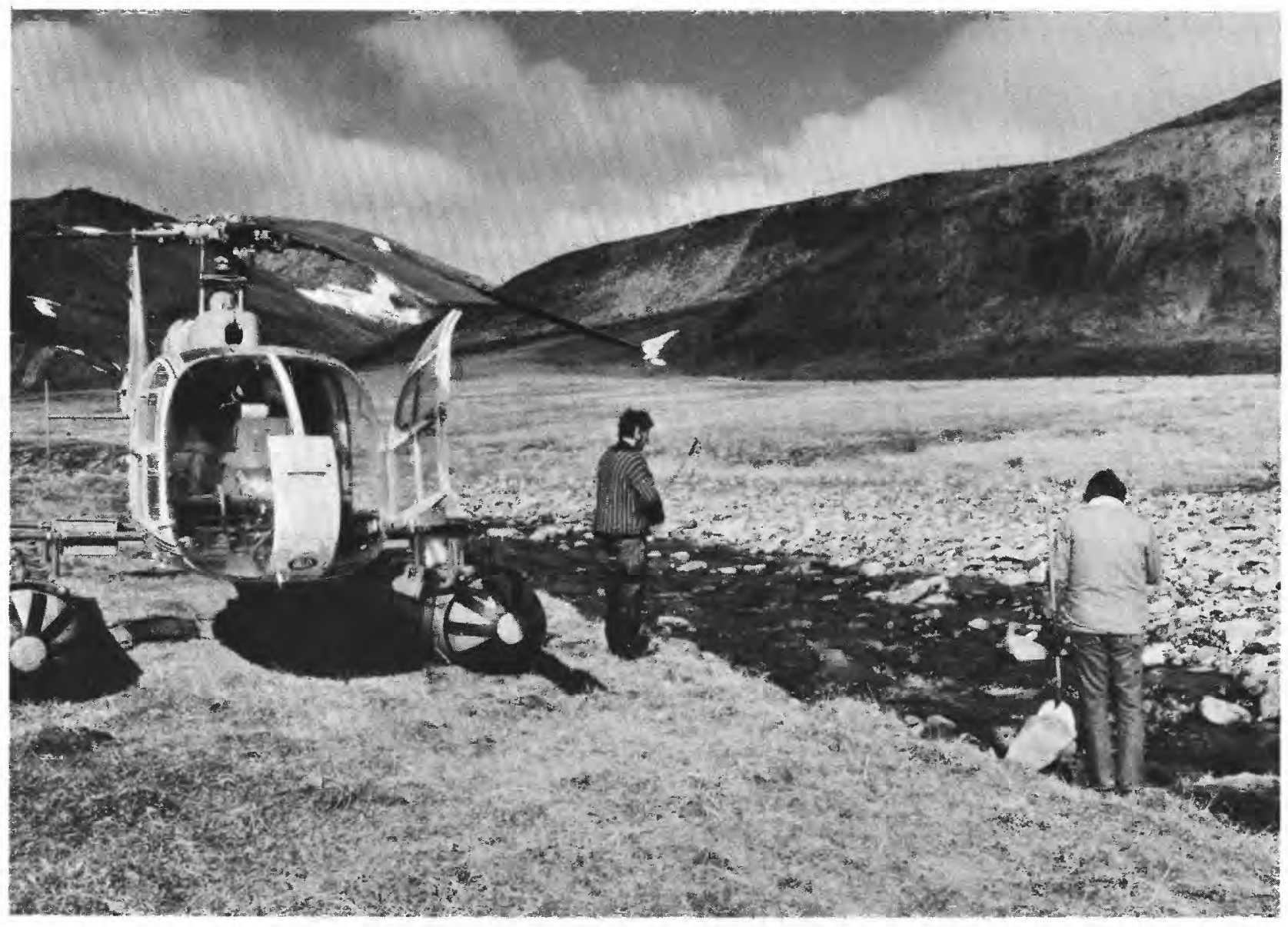

Figure 17.-Water quality sampling at Bogie Creek in the De Long Mountains, June 1977. 


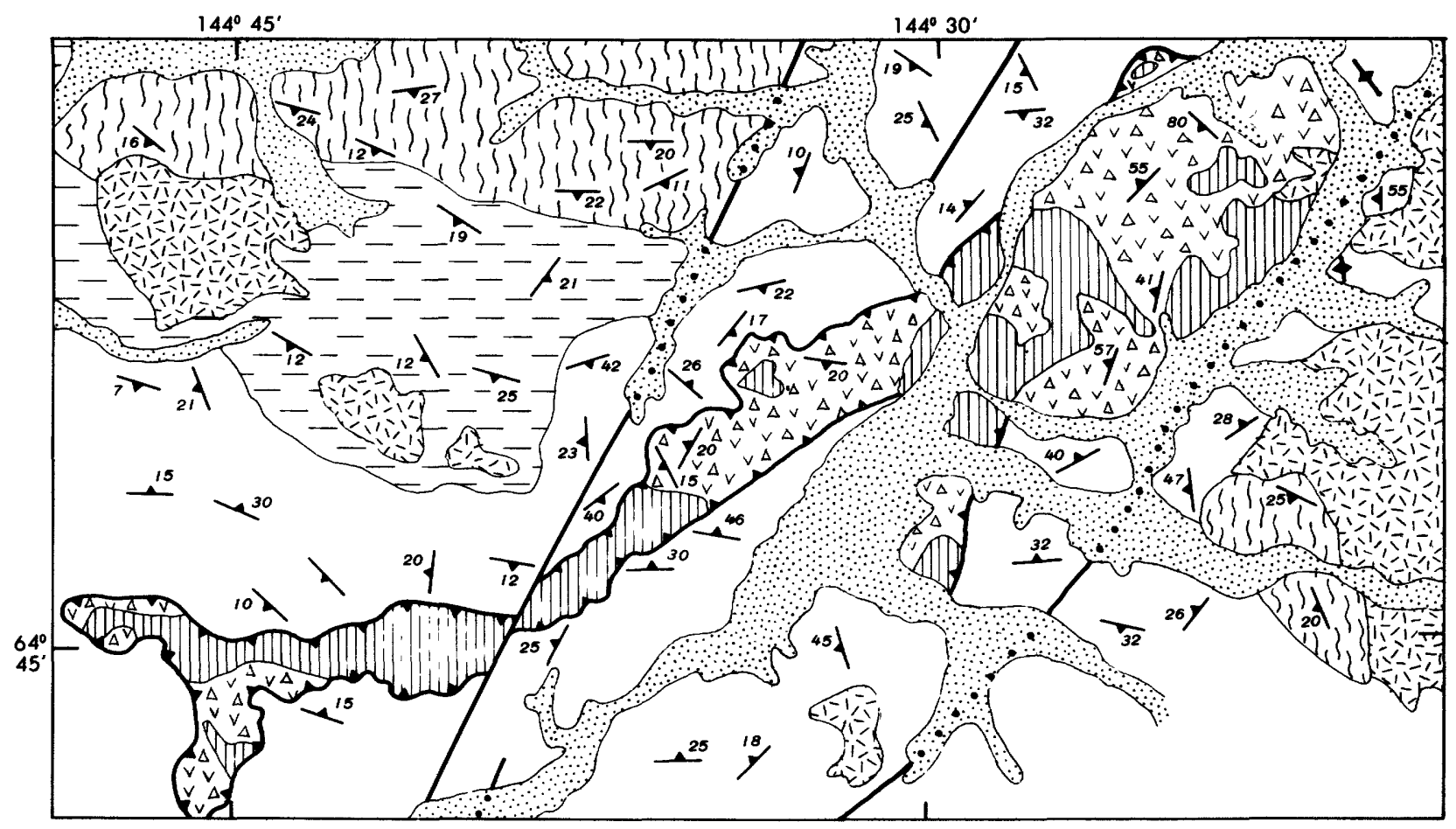

\begin{tabular}{|c|c|}
\hline & Alluvium \\
\hline$v \Delta \Delta_{v}^{v} v_{\Delta v}^{\Delta}$ & Chert and greenstone \\
\hline & Serpentinized ultrama \\
\hline & Green grit unit \\
\hline & Black quartzite unit \\
\hline 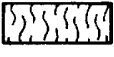 & Schist and gneiss unit \\
\hline$\frac{E-12}{2-1}$ & Granitic rocks \\
\hline
\end{tabular}

EXPLANATION

FIGURE 18.-Geologic map of northeastern Big Delta quadrangle, Alaska, showing new fossil locality.

the first pre-Pleistocene fossils found in the Big Delta quadrangle. The radiolarians are abundant and consist of:

1. Unnamed elongate ladderlike specimens with large reticulate pores,

2. Paronaella sp. forms with complete outer margins connecting the three primary arms, and

3 . Unnamed morphotypes related to late stages of the Family Albaillellidea.

The radiolarians can be matched with species known elsewhere to occur in rocks of Late Pennsylvanian and Early Permian age (D. L. Jones and Brian Holdsworth, unpub. data, 1978).

The conodonts consist of Streptognathus sp., Xaniognathus sp., and juvenile specimens belonging to the genus Neogondolella. The juvenile forms can be assigned to a group of Neogondolella that ranges from late Wolfcampian through Guadalupian (Permian). Streptognathus became extinct before the Guadalupian, so a Wolfcampian age is indicated.

The chert occurs interlayered with basaltic greenstone that, in turn, is associated with serpentized ultramafic rocks. Locally, thin beds of slightly metamorphosed graywacke are also interlayered with the greenstone and chert. Most of the chert is fairly massive, although closely fractured. Much of it has a sugary texture and is too recrystallized for extraction of fossils. Green and gray chert is most abundant, but some red chert is also interlayered. Most of the chert occurs at the northeastern end of the ultramafic outcrops. 
The chert, greenstone, graywacke, and ultramafic rocks are slightly metamorphosed and compose a distinct terrane of oceanic origin that appears to have been thrust over adjacent greenschist, marble, quartzite, and metamorphosed grit. Because of the fault relations, knowledge of the age of the chert does not directly help date the adjacent metamorphic rocks. The age of the chert does document a late Paleozoic or younger period of major tectonic activity during which oceanic rocks were emplaced on the continentally derived metamorphosed substratum that makes up the bulk of east-central Alaska.

Late Cenozoic stratigraphy of the south-central Brooks Range

By Thomas D. Hamilton

Downcutting along parts of the Koyukuk and Chandalar drainage systems has formed bluffs that locally stand 20 to $80 \mathrm{~m}$ high near the south flank of the Brooks Range in the Chandalar, Wiseman, and Bettles quadrangles (fig. 19). Sediments exposed in bluff faces record a sequence of glacial, interglacial, and preglacial events that extends through the Quaternary and probably into late Tertiary time. Many events can be correlated with the standard Brooks Range glacial succession, as defined by Detterman, Bowsher, and Dutro (1958) within the northern Brooks Range and later extended southward by Hamilton and Porter (1975). A

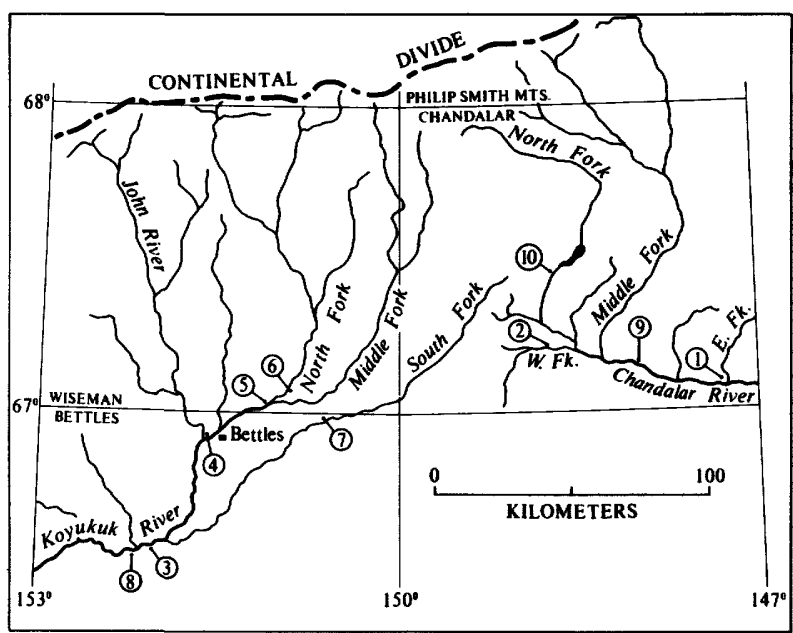

FIGURE 19.-Sketch map showing selected bluff exposures, Koyukuk and Chandalar drainage basins, northern Alaska. general succession of nine climatically controlled events can be grouped into five major time divisions (table 1).

Preglacial gravel is best exposed in high (90$100 \mathrm{~m})$ terraces north of the Chandalar River near the mouth of its East Fork (locality 1 in fig. 19). The clasts, predominantly of pebble size, consist almost entirely of quartz, chert, and quartzite. In comparison with younger alluvium, the clasts are more rounded, better sorted, smaller in mean diameter, and more quartzose. A similar-appearing and possibly correlative gravel lies at the base of an $80-\mathrm{m}$ bluff along the West Fork of Chandalar River (locality 2). This unit is indurated, contains thin lignitized organic beds, and has been tectonically deformed.

TABLE 1.-Stratigraphic succession in the Koyukuk and Chandalar drainage systems, south-central Brooks Range

\begin{tabular}{|c|c|}
\hline Bolocene & $\begin{array}{l}\text { Postglacial downcutting, thaw-1ake formation, and peat } \\
\text { accumulation in major valleys. Accumalation of basin- } \\
\text { fill deposits up-valley from Itkillik II end moraines. }\end{array}$ \\
\hline \multirow{3}{*}{$\begin{array}{l}\text { Late } \\
\text { Plaistocene }\end{array}$} & $\begin{array}{l}\text { IrxruIIK II GLacrarros. Deposition of till, ice- } \\
\text { stagnation deposits, outwash, loess, and proglacial } \\
\text { lake sediments. }\end{array}$ \\
\hline & $\begin{array}{l}\text { Interglacial or interstadial unconforaity with local } \\
\text { peat and forast beds. }\end{array}$ \\
\hline & $\begin{array}{l}\text { Irorutr I GLaciarios. Deposition of till, outwash, and } \\
\text { loess. }\end{array}$ \\
\hline $\begin{array}{l}\text { Middle (?) } \\
\text { Pleistocene }\end{array}$ & $\begin{array}{l}\text { Deposition of interglacial graval, now heavily oxidized. } \\
\text { Sagavaluraxok Rrver Gaciarion. Deposition of younger } \\
\text { pre-Itkillik drift(s). }\end{array}$ \\
\hline \multirow{2}{*}{$\begin{array}{l}\text { Early (?) } \\
\text { Pleistocene }\end{array}$} & Deposition of thick interglacial alluvium. \\
\hline & $\begin{array}{l}\text { MDKTUVUK RIVER GLaciarion. Deposition of older pre- } \\
\text { Itkilik drift (s). }\end{array}$ \\
\hline 7) & Deposition of preglacial gravel. \\
\hline
\end{tabular}

Older pre-Itkillik drift has been mapped locally in the Philip Smith Mountains and Chandalar quadrangles (Hamilton, 1978a, 1978b) and correlated with the Anaktuvuk River Glaciation of Detterman, Bowsher, and Dutro (1958). Till of presumed Anaktuvuk River age is present at the base of a $60-\mathrm{m}$ bluff along the south side of the Koyukuk River downvalley from Bettles (locality 3). A possibly correlative till lies near the base of locality 2 in the Chandalar basin.

Thick interglacial alluvium at locality 2 forms a 54-m deposit that grades upward from crossbedded fine to medium sand at the base into sandy pebble-to-small-cobble gravel near the top. A comparable fluvial sand, $16 \mathrm{~m}$ thick, containing abundant detrital wood is exposed along the Koyukuk River at locality 3, where it lies between drifts of presumed Anaktuvuk River and Sagavanirktok River age. 
Younger pre-Itkillik drift has been mapped as fairly extensive surface deposits in the Philip Smith Mountains, Chandalar, and Wiseman quadrangles (Hamilton, 1978a, 1978b, and unpub. data, 1978) and is correlated with the Sagavanirktok River Glaciation of Detterman, Bowsher, and Dutro (1958). In the Koyukuk basin, boulder-rich diamicton associated with lacustrine clay overlies thick interglacial alluvium and in turn is overlain by heavily oxidized gravel. The diamicton was deposited when Brooks Range glaciers flowed south into the Koyukuk basin and created extensive proglacial lakes (Hamilton, 1969).

Heavily oxidized interglacial alluvium directly underlies till of Itkillik I age in exposures near Bettles and near the mouth of the North Fork of the Koyukuk River (localities 4-6). Along the South fork of the Koyukuk, it underlies unoxidized outwash gravel of the Itkillik I Glaciation (locality 7). Farther west, at localities 3 and 8, the gravel appears at heights of 20 to $40 \mathrm{~m}$ above modern river level in positions stratigraphically below widespread loess and lacustrine silt deposits of Itkillik I age.

Itkillik I drift has been described by Hamilton and Porter (1975) and more recently has been mapped in greater detail within the Philip Smith Mountains, Chandalar, and Wiseman quadrangles (Hamilton, 1978a, 1978b, and unpub. data, 1978). Thick (20 to $40 \mathrm{~m}$ ) sections through Itkillik I end moraines are exposed along the Koyukuk River (for example, localities 4-6), and correlative outwash is exposed in both the Koyukuk and Chandalar basins (for example, localities 7 and 9). Conflicting radiocarbon dates have been obtained on Itkillik I deposits. A maximum limiting age of $35,400 \pm 2,000$ years B.P. was obtained on gravel beneath Itkillik I till at locality 5 (Hamilton and Porter, 1975), but dates obtained subsequently on large wood samples from both the Koyukuk and Chandalar drainages seem to prove that Itkillik I ice advances are older than 40,000 years.

The interval between the Itkillik I and II advances is marked by nondeposition and presumed downcutting at most sites. In several bluff exposures beyond Itkillik ice limits, peat beds containing spruce wood dated at greater than 40,000 years B.P. are present between loess and outwash deposits correlated with the Itkillik I and II advances. If dates and correlations are correct, the Itkillik I Glaciation is older than the late Wisconsin age assigned it by Hamilton and Porter (1975) and is separated from Itkillik II events by an interglacial or mild interstadial warm enough to allow treeline to advance to positions within at least several tens of kilometers of its present limits. On the other hand, absence of pronounced weathering and soil formation suggests that this interval was probably much briefer than any preceding interglaciation.

Itkillik II end moraines usually lie close to the south flank of the Brooks Range and are associated with abundant ice-stagnation deposits and extensive outwash trains (Hamilton and Porter, 1975). Stream incisions through the moraine belts usually expose 10 to $20 \mathrm{~m}$ of unweathered gray till that passes downvalley into terraced outwash deposits 10 to $15 \mathrm{~m}$ high (for example, locality 10). The glacial sediments usually bear less than $0.5 \mathrm{~m}$ of postglacial loess, peat, and sod. Alluviation of presumed Itkillik II age occurred between 13,000 and 24,000 years B.P. in the Koyukuk Valley, and possibly correlative loess at locality 3 contains organic matter near its base that dates $28,500 \pm 775$ years B.P.

Postglacial events have included (1) downcutting along major valleys, (2) alluviation in basins dammed by Itkillik II end moraines, (3) thawlake formation in ice-rich silt deposits of Itkillik age, and (4) reforestation of the larger valleys of the Koyukuk and Chandalar drainage systems. Radiocarbon dates show that downcutting occurred sometime after $13,160 \pm 170$ years B.P. at locality 5 and basin-filling behind Itkillik II moraines commenced shortly before 13,000 years B.P. in the upper Sagavanirktok Valley. Thawlake formation in the Koyukuk basin was initiated about 11,300 years B.P. at one locality.

\section{REFERENCES CITED}

Detterman, R. L., Bowsher, A. L., and Dutro, J. T., Jr., 1958, Glaciation on the arctic slope of the Brooks Range, northern Alaska: Arctic, v. 11, p. 43-61.

Hamilton, T. D., 1969, Glacial geology of the lower Alatna Valley, Brooks Range, Alaska, in Schumm, S. A., and Bradley, W. C., eds., United States contributions to Quaternary research: Geol. Soc. America Spec. Paper 123, p. 181-223.

1978a, Surficial geologic map of the Chandalar quadrangle, Alaska: U.S. Geol. Survey Misc. Field Inv. Map MF-878-A, 1 sheet, scale 1:250,000 (in press).

1978b, Surficial geologic map of the Philip Smith Mountains quadrangle, Alaska: U.S. Geol. Survey Misc. Field Inv. Map MF-879-A, 1 sheet, scale 1:250,000 (in press). 
Hamilton, T. D., and Porter, S. C., 1975, Itkillik glaciation in the Brooks Range, northern Alaska: Quaternary Research, v. 5, p. 471-497.

Geohydrology of the Fairbanks-North Star Borough

By G. L. Nelson

Monitoring of baseflow and ground-water levels in residential areas of the Yukon-Tanana uplands near Fairbanks (fig. 2, area 6) is continuing. Ground-water levels in the fractured rock aquifer have been declining more than $1 \mathrm{~m} / \mathrm{yr}$ in some parts of the upper hills and ridgetops. However, ground-water levels in and baseflow from most areas on the lower slopes are stable.

Ground water contaminated by arsenic or nitrate in excess-of Environmental Protection Agency standards has been found in the fractured rock aquifer in scattered areas of the uplands. Transitions between areas of contaminated ground water and areas of uncontaminated ground water are commonly abrupt and occur over a distance of less than $100 \mathrm{~m}$ in some places. Five test wells were drilled in areas of arsenic-contaminated ground water. Packer tests indicate that some arsenic-contaminated wells receive water from two or more discrete zones within the schist. In some cases it is possible to seal those zones that produce arsenic-rich water and to develop a water supply of acceptable quality and quantity.

\section{Geohydrology of the Delta-Clearwater area By G. L. Nelson}

Three test wells were drilled in the State of Alaska Delta Barley Project area (fig. 2, area 7). Permafrost thickness ranged from 15 to $17 \mathrm{~m}$ in the test wells; the static water level is below the base of the frozen ground.

Large quantities of water are discharged from the springs which feed Clearwater, Sawmill, and Granite Creeks, Clearwater Lake, and the Tanana River, northeast of Delta Junction. In September 1977, discharge at the Clearwater Creek gage and the outlet of Clearwater Lake totaled $34.5 \mathrm{~m}^{3} / \mathrm{s}$. Records at the Clearwater Creek gage, maintained from May to October 1977, show a gradual gage-height rise of $8.5 \mathrm{~cm}$ during this period; gage-height began to decline in October. The maximum gage-height rise due to rainfall runoff was $1.8 \mathrm{~cm}$. In July, a discharge of 20.5 $\mathrm{m}^{3} / \mathrm{s}$ was measured at the gage; in September, $21.3 \mathrm{~m}^{3} / \mathrm{s}$ was measured. The gage height had increased $2.1 \mathrm{~cm}$ between the two measurements. Waller, Feulner, and Tisdel (1962) suggested that the aquifer is recharged by seepage losses from the Delta River and Jarvis Creek, and that the ground water flows northeastward to feed the springs. However, the springs may also be fed by ground-water recharge from the Tanana River east of the springs, the Gerstle River, and several small streams draining the north face of the Alaska Range.

\section{REFERENCE CITED}

Waller, R. M., Feulner, A. J., and Tisdel, F. E., 1962, Ground-water movement in the Fort Greely area, Alaska [abs.], in Alaskan Sci. Conf., 12th, College 1961, Proc.: Sci. Alaska 1961, p. 133-134.

\section{WEST-CENTRAL ALASKA}

Juxtaposed continental and oceanic-island arc terranes in the Medfra quadrangle, west-central Alaska

By William W. Patton, Jr.

Recent geologic mapping in the Medfra quadrangle has revealed the presence of two markedly different geologic terranes (fig. 20). The Nixon Fork terrane, which characterizes the eastern and central parts of the quadrangle, is composed of a thick sequence of lower Paleozoic carbonate rocks overlain by upper Paleozoic and Mesozoic quartz-carbonate terrigenous deposits. The Innoko terrane, which underlies the northwestern part of the quadrangle, is made up of upper $\mathrm{Pa}$ leozoic and Mesozoic radiolarian chert and mafic volcanic and volcaniclastic rocks. The two terranes appear to be in fault contact along a prominent topographic lineament that parallels the Susulatna River valley. Upper Cretaceous and Tertiary(?) sedimentary and volcanic strata overlap both terranes, suggesting that structural juxtaposition occurred prior to middle Cretaceous time.

The Nixon Fork terrane is well exposed in the Medfra quadrangle and can be traced by scattered exposures southward across the Michumina lowlands and Farewell fault to the Lime Hills. The stratigraphic sequence, which clearly has continental affinities, includes an estimated 1,500 to $3,000 \mathrm{~m}$ of shailow-water, fossiliferous limestone and dolomite of Ordovician, Silurian, 


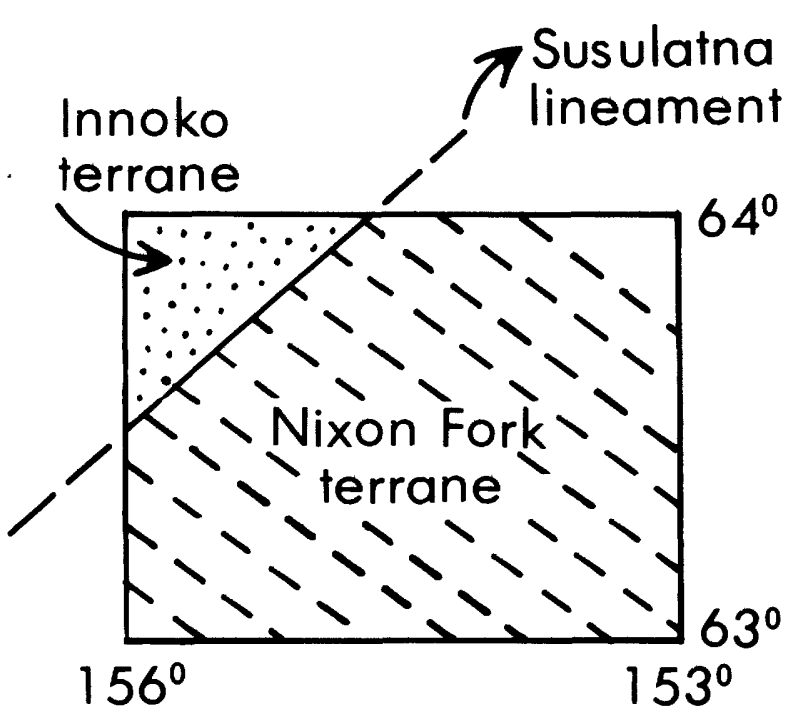

FiguRE 20.-Map of Medfra quadrangle showing areas underlain by Nixon Fork and Innoko terranes.

and Devonian age and 300 to $500 \mathrm{~m}$ of highly fossiliferous limy sandstone, sandy limestone, conglomerate, and spiculite of Permian, Triassic, and Early Cretaceous age (Patton and others, 1977). At the north edge of the Medfra quadrangle, this sequence rests unconformably on a metamorphic complex of probable Precambrian age.

The previously poorly known Innoko terrane is characterized by an assemblage of chert and volcanic rocks that appears to have oceanic or island-arc affinities. Mertie and Harrington (1924) assigned this assemblage a Mesozoic age, but recent mapping by Patton and radiolarian and conodont studies by D. L. Jones and Brian Holdsworth have established that it includes rocks at least as old as Mississippian. Structural complications and poor exposures preclude a detailed stratigraphic breakdown of the assemblage, but three gross lithologic units are mappable. Unit 1, composed of varicolored bedded chert with scattered thin lenticular bodies of limestone, crops out in the extreme northern corner of the quadrangle where it forms a $15-\mathrm{km}$ wide, northeast-trending belt. Radiolarians and conodonts of Mississippian age have been identified at eight widely scattered localities along this belt. Unit 2, made up chiefly of tuff, volcanic conglomerate, breccia, and basalt, forms a northeast-trending, $10-\mathrm{km}$-wide belt bordering the upper Susulatna River. Radiolarians of Triassic age have been recovered from thin intercalated beds of impure chert at five localities within this belt. Unit 3 makes up the bulk of the Cripple Creek Mountains along the western border of the quadrangle and appears to overlie unconformably units 1 and 2 . It is composed of a thick sequence of tuff, volcanic sandstone, and volcanic conglomerate within which were found Inoceramus fragments of probably Early Cretaceous age. The areal extent of the Innoko terrane beyond the Medfra quadrangle is uncertain, but reconnaissance mapping by $R$. M. Chapman (oral commun., 1977) suggests that it can be traced 15 $\mathrm{km}$ northeastward into the Ruby quadrangle and at least $40 \mathrm{~km}$ southwestward into the Ophir quadrangle.

\section{REFERENCES CITED}

Mertie, J. B., Jr., and Harrington, G. L., 1924, The RubyKuskokwim region, Alaska: U.S. Geol. Survey Bull. 754, $129 \mathrm{p}$.

Patton, W. W., Jr., Dutro, J. T., Jr., and Chapman, R. M., 1977, Late Paleozoic and Mesozoic stratigraphy of the Nixon Fork area, Medfra quadrangle, Alaska, in Blean, K. M., ed., United States Geological Survey in Alaska; accomplishments during 1976: U.S. Geol. Survey Circ. 751-B, p. B38-B40.

Preliminary summary of the geology in the northwest part of the Ruby quadrangle

By Robert M. Chapman and William W. Patton, Jr.

Reconnaissance geologic mapping of the area north of the Yukon River in the Ruby quadrangle was completed in 1977 by R. M. Chapman and W. W. Patton, Jr. A preliminary geologic map of the area is shown in figure 21; as office and analytical studies are still in progress, this report includes only brief descriptions of the major rock units and more significant discoveries. This area is situated on the southeast border of the Yukon-Koyukuk basin and includes both Cretaceous rocks of the basin and pre-Cretaceous rocks of the borderland. It is bounded on the south by the Kaltag fault (Patton, 1973). The rock units are correlative with units in the Melozitna quadrangle just to the north (Patton and others, 1978), and the same structural trends prevail.

The gneissic rocks (fig. 21), which form most of the highest part of the Kokrines Hills, are chiefly garnetiferous quartz-feldspar-biotite gneiss of almandine-amphibolite facies, but include some quartzitic gneiss, amphibolitic gneiss, migmatite, small bodies of marble, and a few small bodies of 


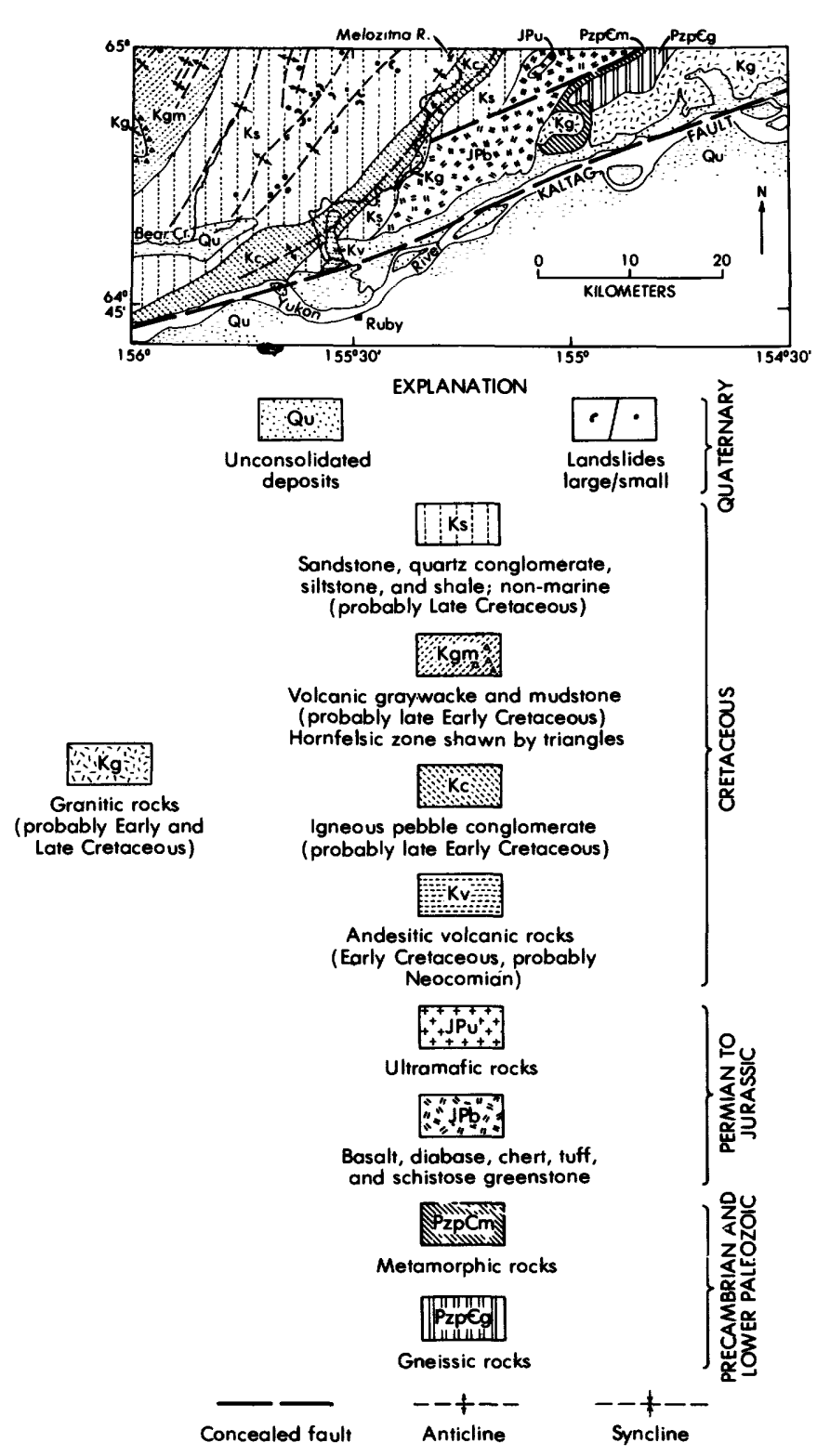

FIGURE 21.-Preliminary geologic map of northwest part of Ruby quadrangle.

granitic rock. The metamorphic rocks include pelitic schist, quartzite, and calcareous to dolomitic marble, generally of greenschist facies. The stratigraphic relation between these two units and their ages are uncertain.

The extrusive and intrusive basalt, diabase, chert, tuff, and schistose greenstone probably range in age from Permian to Jurassic. The nature of the contact between this unit and the older rocks is uncertain. A small unit of ultramafic rocks, largely serpentinized peridotite, together with minor amounts of gabbro, lies within the unit of basalt, diabase, chert, tuff, and schistose greenstone at the north edge of the map area.

A Lower Cretaceous unit of probably Neocomian age, previously unknown along the southeastern margin of the Yukon-Koyukuk province, was found on the Melozitna River $6 \mathrm{~km}$ north of its mouth. This unit, at least $300 \mathrm{~m}$ thick, consists primarily of andesitic flows, but also includes some volcaniclastic and fine-grained tuffaceous rocks, and shaly sedimentary rocks. Andesitic to basaltic volcanic and interlayered conglomeratic sedimentary rocks on a hilltop on the east side of the Melozitna River and $10 \mathrm{~km}$ north of the mouth may also be part of this unit. This unit is similar to the Lower Cretaceous (Neocomian) unit of andesitic volcanic rocks exposed over $60 \mathrm{~km}$ to the north in the Melozitna quadrangle (Patton and others, 1978). A few fossil ferns, collected in 1977 from the section on the Melozitna River, are not well enough preserved to demonstrate details of venation or other specific characters, but the size and shape of the pinules conform quite nicely with those of the genus Cladophlebis, which is common in the Mesozoic; also these specimens do not resemble any ferns known in the North American Permian (S. H. Mamay, written commun., 1977). Ferns of this genus have been found in rocks of late Early Cretaceous (Albian) or Late Cretaceous age about 32 km west along the Yukon River (Hollick, 1930, p. 39 ). The rock assemblage plus the fossil evidence strongly favor a Neocomian age for the andesitic unit. A correlation with the basalt, diabase, chert, tuff, and schistose greenstone unit, which immediately underlies Cretaceous clastic rocks east of the Melozitna River, seems unlikely because the volcanic rocks in that unit are predominantly basaltic rather than andesitic and generally lack a large component of coarse volcaniclastic rocks. Only late Paleozoic fossils are known in the basaltic unit farther east along the Yukon River valley and to the northeast in the Kanuti River region.

Andesitic rocks were not found elsewhere in this part of the Ruby quadrangle. Apparently these rocks are overlapped and concealed by post-Neocomian conglomeratic rocks to the northeast along the margin of the Yukon-Koyukuk province.

The post-Neocomian Cretaceous clastic rock units probably range in age from late Early Cre- 
taceous (Albian) to early Late Cretaceous and are correlative with similarly designated units in the Melozitna quadrangle. The rocks are only moderately deformed by a series of broad anticlines and synclines in which bedding dips rarely exceed $45^{\circ}$. Some crystal-lithic tuff, volcanic graywacke, and related rocks, resembling those in the tuff, volcanic graywacke, and mudstone unit of the Melozitna quadrangle (Patton and others, 1978), are included in the three post-Neocomian units shown in figure 21 .

The granitic rocks have not yet been studied petrographically or dated; quartz monzonite, granite(?), and granodiorite that are probably Early and Late Cretaceous age are included. The pluton in the Kokrines Hills is chiefly quartz monzonite and is part of the large Melozitna pluton that has yielded a potassium-argon age of 111 m.y. (Patton and others, 1978). A small linear body of deeply weathered granite or quartz monzonite, including xenoliths of mafic rock, is exposed over a distance of $5 \mathrm{~km}$ in the Melozitna River canyon. A granodiorite stock, at the west edge of the map area, has intruded and altered volcanic graywacke and mudstone of probable Albian age to hornfels. Similar granodiorites in the Melozitna quadrangle have provided potassium-argon ages of 81.5 to 89.0 m.y. (Patton and others, 1978).

Only the major areas of unconsolidated deposits are shown (fig. 21). These deposits are chiefly younger and older flood-plain silt, sand and gravel, and colluvial and eolian slope deposits. Numerous landslide deposits, which lie outside these areas, are shown by symbols and discussed in the following report.

\section{REFERENGES CITED}

Hollick, Arthur, 1930, The Upper Cretaceous floras of Alaska: U.S. Geol. Survey Prof. Paper 159, 123 p.

Patton, W. W., Jr., 1973, Reconnaissance geology of the northern Yukon-Koyukuk province, Alaska: U.S. Geol. Survey Prof. Paper 774-A, 17 p.

Patton, W. W., Jr., Miller, T. P., Chapman, R. M., and Yeend, Warren, 1978, Geologic map of the Melozitna quadrangle, Alaska: U.S. Geol. Survey Misc. Geol. Inv. Map I-1071, 1 sheet, scale 1:250,000 (in press).

Landslides near Melozitna River canyon By Robert M. Chapman and W. W. Patton, Jr.

Eight large landslides and sixteen smaller ones have been mapped within a northeast-trending, $165-\mathrm{km}^{2}$ area that is 6 to $13 \mathrm{~km}$ northwest of the Melozitna River canyon in the Ruby quadrangle. Two more small landslides are present a few kilometers west of this area. Several of the large landslides were first noted from the air by the writers in 1974. Ground and low-level aerial observations and aerial photointerpretation in connection with reconnaissance geologic mapping in 1977 led to identification of the 26 landslides shown in figure 21 . With more detailed fieldwork, probably a few more small landslides could be found northwest of the Melozitna River and also in the hills between the Yukon River and Bear Creek.

The large landslides, six of which face south, descend from altitudes of $610-700 \mathrm{~m}$ at the heads of small stream valleys and range from 0.8 to 1.4 $\mathrm{km}$ in width at the head and from 0.8 to $1.6 \mathrm{~km}$ in length from crown to toe. They apparently formed as rotational slumps that grade to debris slides and earthflows in the lower parts. The slide material consists of bedrock slump blocks and bedrock debris from the Cretaceous clastic rocks. The headward part of a large landslideis shown in figure 22 . A few tiny lakes occupy shallow depressions in three of the slides. The smaller slides include debris slides and some rotational and planar slumps and are located both at the heads of valleys and gullies and along side slopes in the upper parts of stream valleys. They generally descend from an altitude of about $460 \mathrm{~m}$.

The landslides are in, or close to, the axial zones of synclines and an anticline where the beds generally dip $10^{\circ}$ or less and apparently are not deformed by minor folds and faults. In most of the slides the rupture planes are nearly normal to the bedding planes, and there is no apparent control by faults, joints, or incompetent stratigraphic units. As shown in figure 21, 24 of the landslides are located along the anticline and syncline that trend northeast from the head of Bear Creek; the other two landslides are in the axial zones of two synclines to the west of these major structures.

Most of the landslides apparently have long been nearly stable and are thinly to moderately covered by a normal vegetation of brush and small trees, except for the nearly barren steep main and flank scarps. These slides are probably at least a few thousand years old, and perhaps as old as late Pleistocene. Some of the small slides may be considerably younger, but none is fresh. 
The large landslides superficially resemble cirque glacier features and apparently are what Eakin (1916) interpreted as evidence for small glaciers that left only insignificant deposits in the uplands just west of the Melozitna Canyon. True cirque glacier features, including bouldery till, small moraines, and tarns, are present in several places 25 to $55 \mathrm{~km}$ to the east on the high north slopes of the Kokrines Hills (Eakin, 1916; Patton and others, 1978). The cirque glaciers were confined to northerly facing valley heads at altitudes of 790 to $920 \mathrm{~m}$ (2,600-3,000 ft). In contrast, the features west of the Melozitna River canyon are at lower altitudes, commonly on wellexposed south-facing slopes, and include detached bedrock blocks and modified transverse minor scarps and cracks that are typical of landslides.

\section{REFERENCES CITED}

Eakin, H. M., 1916, The Yukon-Koyukuk region, Alaska: U.S. Geol. Survey Bull. 631, 88 p.

Patton, W. W., Jr., Miller, T. P., Chapman, R. M., and Yeend, Warren, 1978, Geologic map of the Melozitna quadrangle, Alaska: U.S. Geol. Survey Misc. Geol. Inv. Map I-1701, 1 sheet, scale 1:250,000 (in press).

An occurrence of parsonite, a secondary uranium mineral, in alaskite of the Wheeler Creek pluton By Thomas P. Miller and Bruce R. Johnson

Reconnaissance investigations in the Purcell Mountains (fig. 23) in 1977 revealed the presence of parsonite, a hydrous phosphate of lead and uranium with the formula $\mathrm{Pb}_{2} \mathrm{UO}_{2}\left(\mathrm{PO}_{4}\right)_{2} \cdot 2 \mathrm{H}_{2} \mathrm{O}$. This is the first reported occurrence of parsonite in Alaska although other uranium phosphate minerals have been reported elsewhere, for example at Bokan Mountain in southeastern Alaska (MacKevett, 1963). Parsonite has previously been reported (Rich and others, 1977) at such hydrothermal uranium deposits as those in the two-mica granites of the Limousin region of west-central France, the uraniferous granites of central Portugal, and the Shinkolobwe deposit of Zaire.

The parsonite occurs as a soft, yellow to chorolate brown coating closely associated with green muscovite on fracture surfaces in a shear zone in alaskite of the Wheeler Creek pluton (fig. 23). Thin magnetite veinlets are also present. The identification of parsonite was confirmed by $\mathrm{X}$-ray diffraction. Intensive frost action has re- duced alaskite outcrops to rubble so the true width of the parsonite-bearing material is uncertain, but strongly radioactive material occurs scattered over an area about $3 \mathrm{~m}$ wide by $20 \mathrm{~m}$ long. Radioactivity readings of up to $10,000 \mathrm{cps}$ (counts per second) were obtained in this area.

The parsonite locality noted in this report was the only one found during this reconnaissance study. Because of the narrowness of the parsonite-bearing zone, however, detailed and closely spaced traversing would be necessary to determine whether similar zones exist elsewhere in the alaskite.

Coarse-grained alaskite underlies the west end of the Wheeler Creek pluton and intrudes Lower Cretaceous andesitic volcanic rocks, Upper Cretaceous rhyodacite hypabyssal rocks, and the Upper Cretaceous porphyritic quartz monzonite of the Wheeler Creek pluton (Miller, 1970). The area underlain by alaskite (approximately 100 $\mathrm{km}^{2}$ ) is characterized by rounded pink-colored hills covered with a thick mantle of gruslike material through which scattered outcrops protrude. The alaskite itself is a massive rock characterized by large (up to $10 \mathrm{~mm}$ ) black smoky quartz anhedra in a setting of pink feldspar anhedra. The abundance of black smoky quartz gives the rock the superficial appearance of being quite mafic, but it is a true alaskite with generally less than 1 percent mafic minerals, although locally near the contacts the mafic mineral content may be as high as 8 percent. Large clusters of black smoky quartz, purple amethyst crystals (individual crystals as much as $100 \mathrm{~mm}$ long), and white quartz crystals (as large as 250 $\mathrm{mm}$ ) are found locally in the grus mantle and probably represent the weathered remnants of large quartz-filled vugs and miarolitic cavities.

The alaskite is composed mainly of potassium feldspar, chiefly patch perthite with minor amounts of albite and abundant quartz. Biotite is the principal mafic mineral, but hornblende occurs locally near the contact with country rock; magnetite and less commonly allanite are accessory minerals. A potassium-argon age measurement of $77.9 \pm 2.3 \mathrm{~m} . y$. (Late Cretaceous) has been obtained on biotite from the alaskite (Miller, 1970).

High radioactivity readings ranging from 400 to $600 \mathrm{cps}$ on a hand-held scintillometer were obtained over the alaskite. Delayed neutron analyses of two samples of typical alaskite show 14.4 


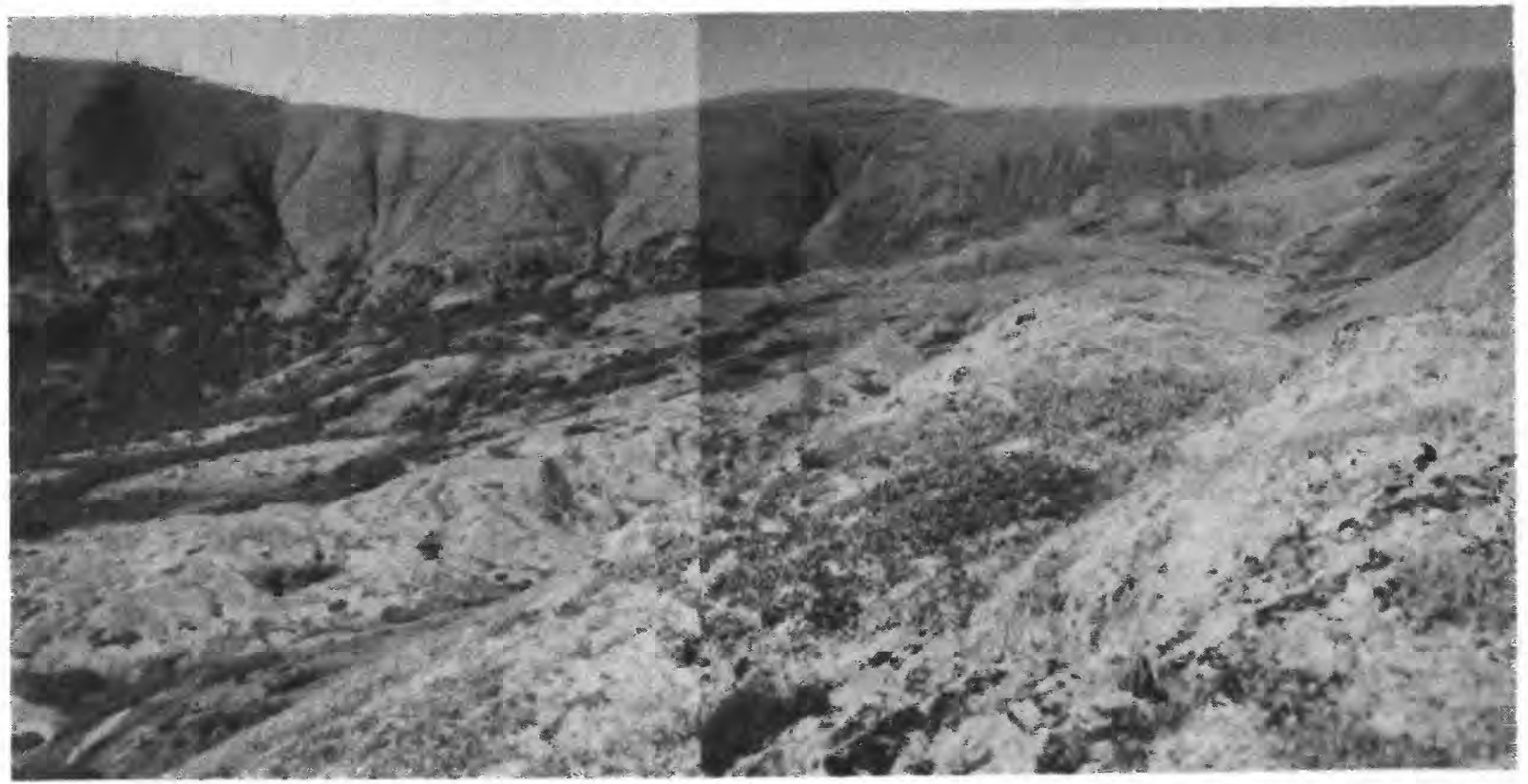

FIGURE 22.-Headward part of a large landslide north of Melozitna River canyon.

ppm and 13.4 ppm uranium and 52.3 and 45.2 ppm thorium, respectively (table 2). Eakins (1977) reported anomalous amounts of uranium in stream sediment samples collected from streams south and east of the parsonite locality.

Delayed neutron analyses were also run on two samples of altered alaskite from the parsonitebearing zone. A fist-size grab sample of altered alaskite with a visible coating of parsonite along one side yielded 4,459 ppm uranium (No. 3, table 2 ); laboratory radioactivity readings of $1,600 \mathrm{cps}$ were obtained from a hand-held scintillometer on the side containing parsonite. A sample of similar size containing little or no visible parsonite (No. 4, table 2) yielded 881 ppm uranium. It is uncertain whether other uranium-bearing minerals besides parsonite are present; however, those samples containing visible parsonite emitted by far the highest radioactivity. Uranium analyses of individual grab samples, therefore, probably are a reflection of the parsonite content.

The original source of the uranium in the parsonite is unknown. The occurrence of an oxidized uranium mineral associated with a shear zone in the uraniferous alaskite certainly indicates secondary concentration of uranium. The parsonite, therefore, may indicate the possible occurrence of primary uranium minerals elsewhere in the
TABLE 2.-Delayed neutron determinations of uranium and thorium, in parts per million, of selected grab samples, Wheeler Creek pluton

[Analysts: H. T. Millard, Jr., C. M. Ellis, C. McFee. CV, coefficient of variation, or one standard deviation, based on counting statistics, expressed as percentage of concentration. Concentrations with $\mathrm{CV}>30$ percent are enclosed in parentheses and should not be considered reliable]

\begin{tabular}{|c|c|c|c|c|c|}
\hline Lab No. & Uranium & $\mathrm{CV}$ & Thorium & $\mathrm{CV}$ & Remarks \\
\hline D186403 & 14.42 & 1 & 52.27 & 4 & Typical alaskite \\
\hline D186404 & 13.43 & 2 & 45.14 & 4 & Typical alaskite \\
\hline D195038 & 4459.08 & 1 & $(565.97)$ & 64 & $\begin{array}{l}\text { Altered alaskite } \\
\text { with abundant } \\
\text { visible parsonite }\end{array}$ \\
\hline D195039 & 881.12 & 1 & $(0.00)$ & 50 & $\begin{array}{l}\text { Altered alaskite } \\
\text { with little or no } \\
\text { visible parsonite }\end{array}$ \\
\hline
\end{tabular}

alaskite or the possibility of more widespread secondary enrichment of the uraniferous alaskite.

\section{REFERENCES CITED}

Eakins, G. R., 1977, Reconnaissance program, west-central Alaska and Copper River Basin, Part 1, in Investigation of Alaska's uranium potential: U.S. Energy Research and Development Admin. Rept. GJO-1639, 51 p.

MacKevett, E. M., Jr., 1963, Geology and ore deposits of the Bokan Mountain uranium-thorium area, southeastern Alaska: U.S. Geol. Survey Bull. 1154, 125 p. 

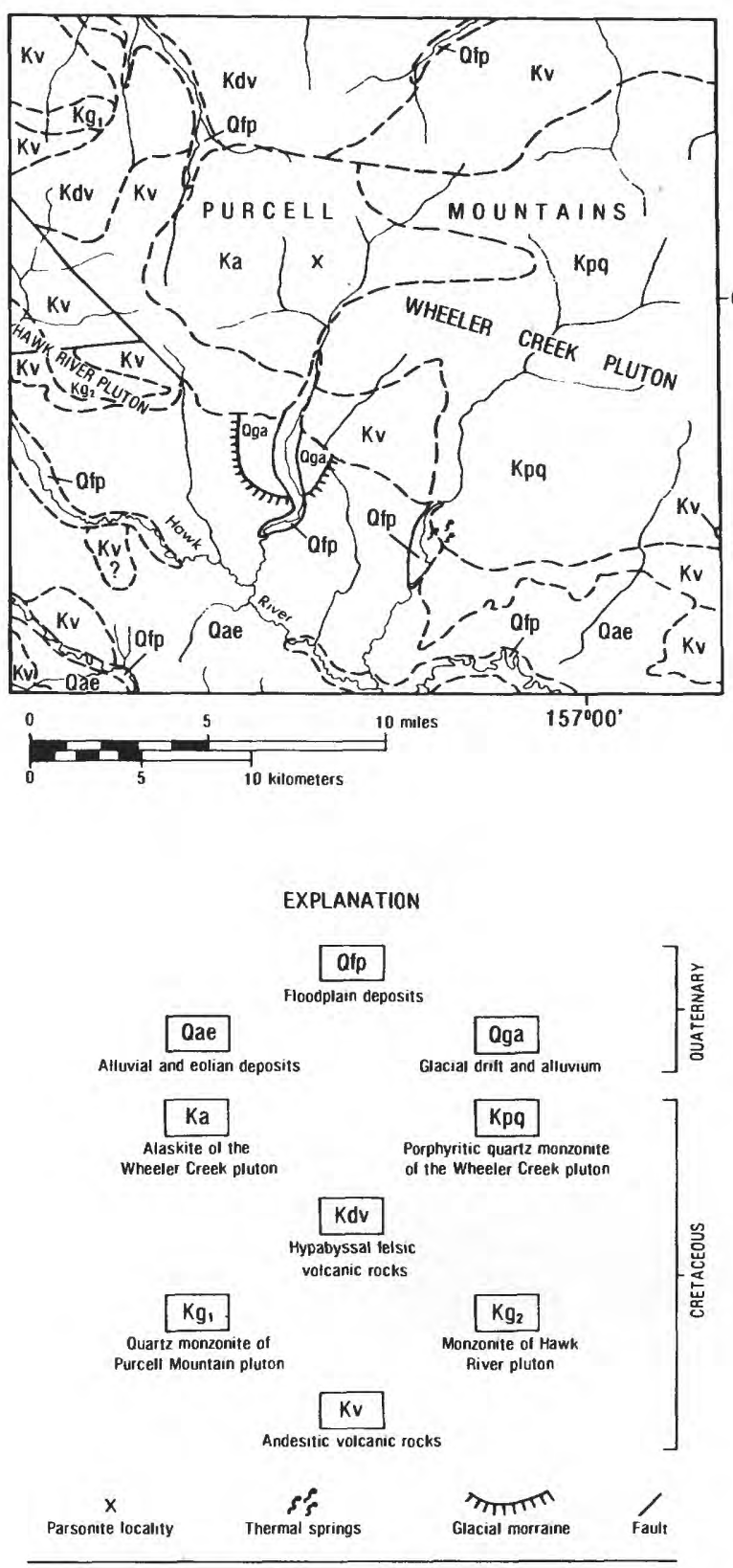

FIGURE 23.-Generalized geologic map of the western Purcell Mountains. Modified slightly from Patton, Miller, and Tailleur (1968).

Miller, T. P., 1970, Petrology of the plutonic rocks of westcentral Alaska: U.S. Geol. Survey Open-File Report, $132 \mathrm{p}$.

Patton, W. W., Jr., Miller, T. P., and Tailleur, I. L., 1968, Regional geologic map of the Shungnak and southern part of the Ambler River quadrangles, Alaska: U.S. Geol. Survey Misc. Geol. Inv. Map I-554, scale $1: 250,000$.
Rich, R. A., Holland, H. D., and Petersen, Ulrich, 1977, Hydrothermal uranium deposits: New York, Elsevier Sci. Pub. Co., 264 p.

Tin-granites of Seward Peninsula

By Travis Hudson, Fred Barker, and Joseph Arth

Brief field studies of the granite plutons of Seward Peninsula that are spatially associated with tin mineralization were completed during July 1977. These studies were undertaken to identify the general petrologic nature of the plutons and to obtain representative samples of lithologic facies in them. The samples were collected for petrologic, chemical, and isotopic laboratory studies directed toward understanding the origin of the parent magmas. Altogether, seven granite stocks of northwestern Seward Peninsula and the northern part of the Darby batholith in eastern Seward Peninsula were sampled (fig. 24).

The field studies revealed the following general relations:

1. Tin-granite complexes at Cape Mountain, Brooks Mountain, and Ear Mountain are composite epizonal stocks similar to the granite complex of the Serpentine Hot Springs area (Hudson, 1977) in that they contain seriate-textured biotite granite and porphyritic biotite granite with aplitic to fine-grained equigranular groundmass. Late-stage fine- to medium-grained equigranular intrusions are present at Cape Mountain and Ear Mountain.

2. Tin-granite plutons at Lost River, Tin Creek, and Black Mountain contain equigranular biotite granite. The Lost River and Tin Creek

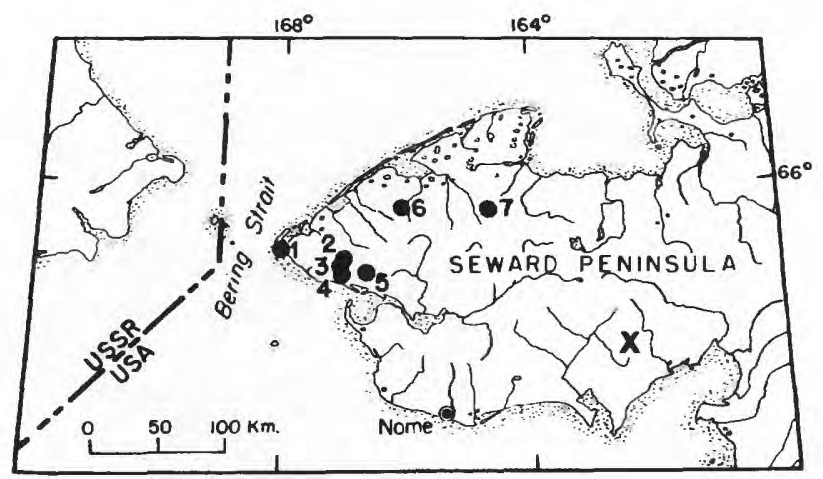

Figure 24.--Location of Seward Peninsula tin-granites. 1. Cape Mountain 2. Brooks Mountain 3. Lost River 4. Tin Creek 5. Black Mountain 6. Ear Mountain 7. Serpentine Hot Springs X. NorthernDarby Mountain batholith. 
plutons may be similar to late-stage fine- to medium-grained equigranular granite intrusions at Cape Mountain, Ear Mountain, and in the Serpentine Hot Springs area.

3. The Darby batholith is composite and contains late intrusions of porphyritic biotite granite with aplitic to fine-grained equigranular groundmass. This facies appears to be similar to major parts of the Cape Mountain, Brooks Mountain, and Serpentine Hot Springs granite complexes of northwestern Seward Peninsula. The presence of placer cassiterite on Otter Creek (Herreid, 1965, p. 5), high concentrations of tin in lead-silver deposits of the Omilak area (Mulligan, 1962), and the apparent similarity of parts of the northern Darby batholith to parts of some northwestern Seward Peninsula tin-granite complexes suggest that undiscovered lode tin deposits may be present in the northern Darby Mountains.

Laboratory studies of representative samples of the exposed granites have begun. These studies should clarify important similarities or differences between the several plutons and add to our understanding of the origin of the parent magmas.

\section{REFERENCES CITED}

Herreid, Gordon, 1965, Geology of the Omilak-Otter Creek area, Bendeleben quadrangle, Seward Peninsula, Alaska: Alaska Div. Mines and Minerals Geol. Report 11, $12 \mathrm{p}$.

Hudson, Travis, 1977, Genesis of a zoned granite stock, Seward Peninsula, Alaska: U.S. Geol. Survey Open-File Report 77-35, $188 \mathrm{p}$.

Mulligan J. J., 1962, Lead-silver deposits in the Omilak area, Seward Peninsula, Alaska: U.S. Bur. Mines Report Inv. 6018,44 p.

Upper Triassic radiolarian chert from the Kobuk volcanic sequence in the southern Brooks Range By George Plafker, Travis Hudson, and D. L. Jones

During the course of reconnaissance field studies of the Kobuk fault zone, age-diagnostic radiolarian cherts were collected from an unnamed sequence of predominantly mafic volcanic rocks that forms a discontinuous belt along much of the southern foothills of the Brooks Range. The cherts were collected at two localities from this sequence of rocks, informally referred to herein as the Kobuk volcanic sequence, in the Helpmejack Hills in the Hughes quadrangle (fig. 25).
Chert, with associated bedded sedimentary rocks, occurs in at least three thin zones, less than $200 \mathrm{~m}$ thick, interbedded with the Kobuk volcanic sequence, which trends east-west and has an outcrop width of about $5 \mathrm{~km}$ in the Helpmejack Hills. Patton and Miller (1966) mapped these hills as altered mafic volcanic rocks of Jurassic age. The volcanic rocks are predominantly massive to pillowed basalt and basaltic breccia that have been slightly to strongly altered to greenstone. Dips are generally more than $60^{\circ}$ and, in the one locality where tops could be determined from pillow structures, they face south. The predominantly volcanic sequence is bounded on the north by a unit of undifferentiated chloritic phyllite, quartz-mica schist, and quartzite of possible Devonian age, and on the south by Cretaceous conglomerate (fig. 25). Structural relations between bedrock units were not determined during our brief reconnaissance study, but structure appears to be complex, and the volcanic sequence may be cut by one or more thrust faults.

Age-diagnostic radiolarians were collected from cherts at two of the three field stations at which sedimentary rocks were found within the Kobuk volcanic sequence (fig. 25). These sedimentary units underlie broad saddles in the topographically rugged volcanic terrain. At station 77APr91 a band of gray, green, black, and white radiolarian-rich ribbon chert, approximately 50 $\mathrm{m}$ thick, apparently overlies and is possibly intercalated with greenstone breccia along the southern margin of the saddle. The main part of the saddle to the north in underlain by thin, discontinuous limestone lenses containing poorly preserved megafossils within a sequence, roughly $150 \mathrm{~m}$ thick, of green tuff, black phyllite, and gray volcanogenic sandstone. The geologic relations between the cherty rocks and the bedded fossiliferous sedimentary and volcanic rocks are not known because the contact is not exposed. The abrupt lithologic change, however, suggests that it is a fault. At station 77APr89 a poorly exposed sequence of thinly bedded reddish-brown, green, gray, black, and white chert with moderately abundant radiolarians occurs as rubble or is discontinuously exposed in a few riblike outcrops, as much as $2 \mathrm{~m}$ thick, within a saddle approximately $200 \mathrm{~m}$ wide. Although float of chert and limestone was observed at the saddle in the basaltic terrane at station 77APr90, the chert did 
$154^{\circ} \mathrm{OO}$

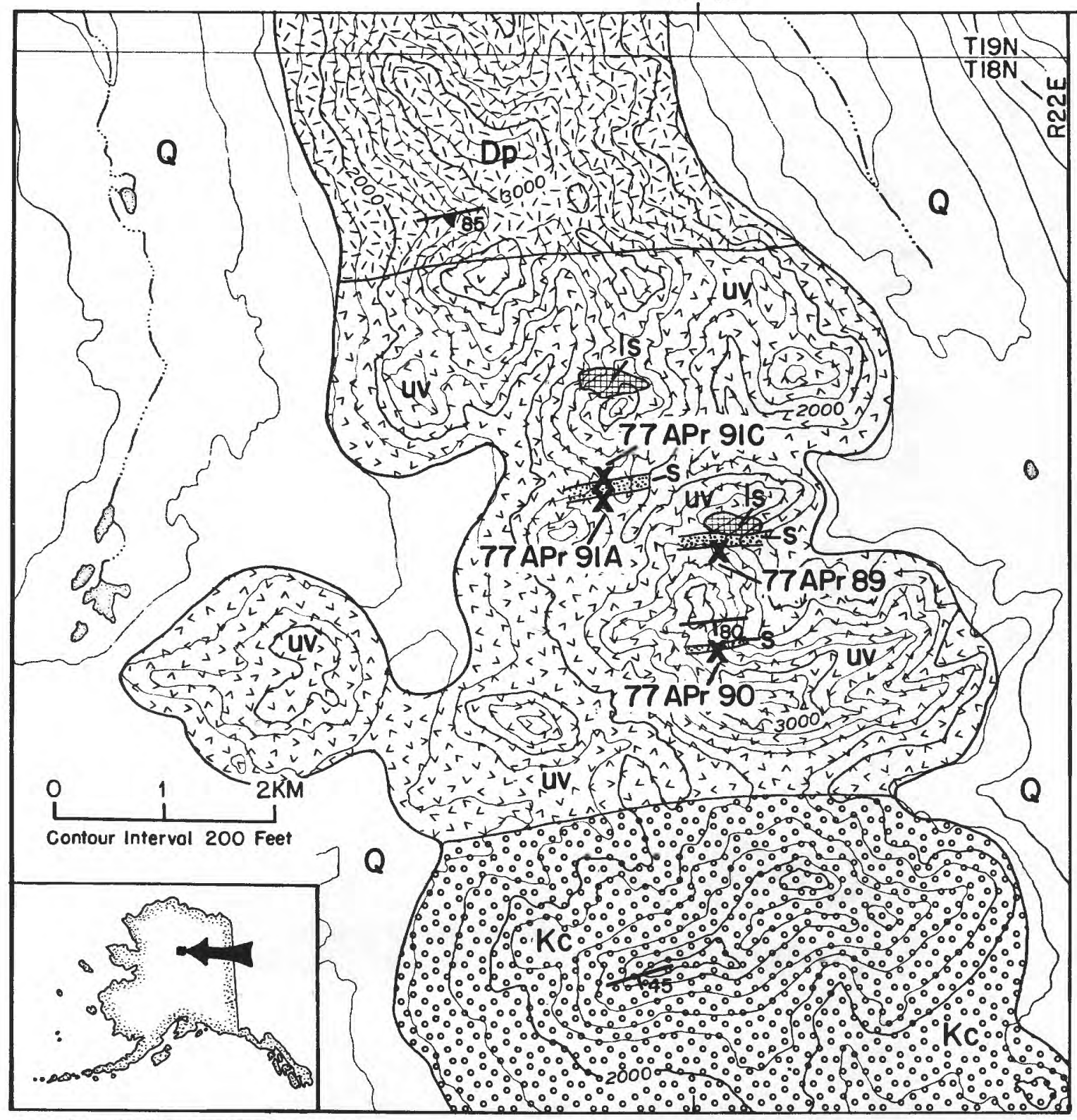

Bose from USGS Hughes quodrangle, scale $1: 250,000$

Figure 25.-Map showing Upper Triassic radiolarian chert (77APr89, 77APr90, 77APr91A) and Carboniferous megafossil (77APr91C) localities within the Kobuk volcanic sequence. Dp, Devonian(?) metamorphic rocks; Kc, Cretaceous conglomerate; Q, unconsolidated Quaternary deposits; uv, undifferentiated mafic volcanic rocks; $s$, chert-bearing sedimentary rocks; ls, limestone. Geology modified from Patton and Miller (1966).

not contain megascopically visible radiolarians and was not sampled.

Sample 77APr89A from station 89 yielded radiolarians of Late Triassic age, including: Pseudoheliodiscus sp., Crucella sp., "Eptingium," and Tripocyclia sp. (fig. 26). Conodont frag- ments are also present. The radiolarians are similar to dated Triassic faunas known from Baja California, central Oregon, and elsewhere (E. A. Pessagno, Jr., oral commun., 1977). The chert at locality 77APr91A contains only poorly preserved nasselarian dictyomitrid cones and 


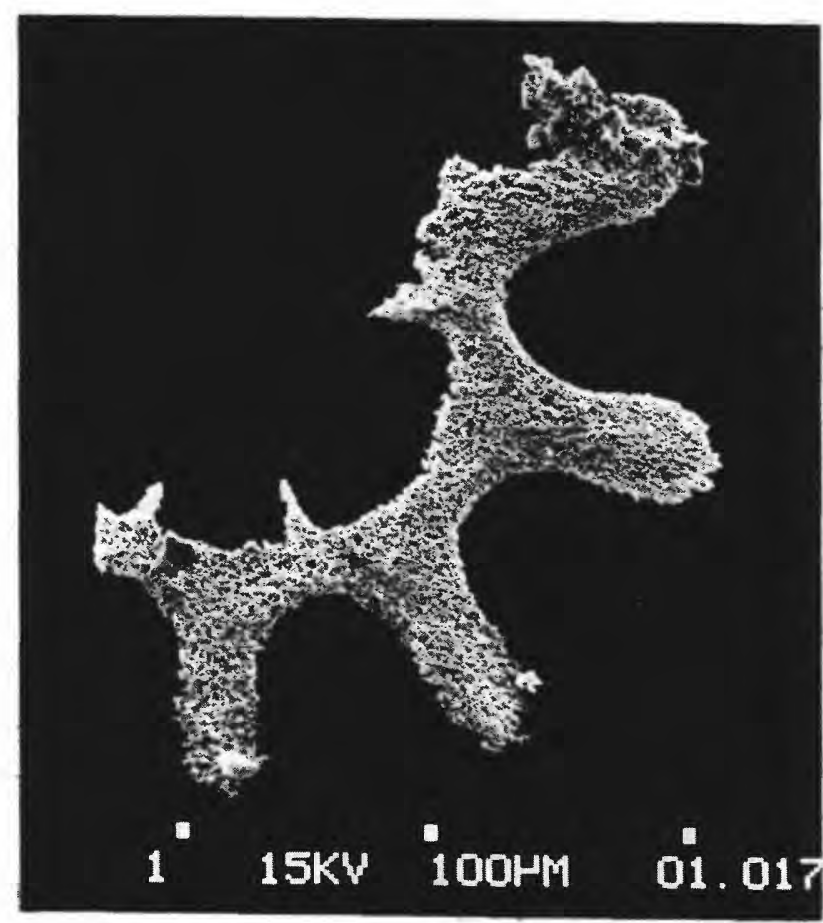

FIGURE 26.-Pseudoheliodiscus sp. from sample 77APr89. This radiolarian is similar to Late Triassic (Norian) forms.

can be dated only as Mesozoic. The radiolarians are the only datable fossils that have been obtained from the pelagic sedimentary rocks interbedded with the Kobuk volcanic sequence, and they should provide the best available control on the age of that part of the terrane in which they occur.

The megafauna in sample 77APr91C from the north side of the saddle at station 91 contains a fossil coral that is probably Diphyllum sp., which is definitely Carboniferous, and probably assignable to the Meramecian Provincial Series of the Mississippian (A. K. Armstrong, written commun., 1977). The occurrence of upper Paleozoic shallow-water rocks in close association with Mesozoic pelagic cherts suggests that the rocks have been structurally juxtaposed.

The mafic volcanic sequence from which the radiolarians were obtained is considered by Patton, Tailleur, Brosgé and Lanphere (1978) to be part of an extensive ophiolite terrane in northern Alaska which has been termed the Yukon-Koyukuk ophiolite belt. Previous interpretations of the age of the Kobuk volcanic sequence in this belt have been based on sparse megafossils and foraminifers obtained from limestone lenses or blocks occurring within the sequence or from ra- diometric ages of igneous rocks thought to be part of the sequence. The basaltic rocks associated with the radiolarian cherts were originally assigned a probable Jurassic age by Patton and Miller (1966), but they are now considered by Patton, Tailleur, Brosgé and Lanphere (1978) to be of probable late Paleozoic age. Our data indicate that, although late Paleozoic fossils do occur in the terrane, at least part of the Kobuk volcanic sequence is of Late Triassic age. These new data provide important constraints on the age of oceanic rocks that constitute the Kobuk volcanic sequence, on correlations of this sequence with ophiolites elsewhere in northern and central Alaska, and on the history of accretion of these oceanic rocks to the continental margin.

\section{REFERENCES CITED}

Patton, W. W., Jr., and Miller, T. P., 1966, Regional geologic map of the Hughes quadrangle, Alaska: U.S. Geol. Survey Misc. Geol. Inv. Map I-459, 1 sheet, scale 1:250,000.

Patton, W. W., Jr., Tailleur, I. L., Brosgé, W. P., and Lanphere, M. A., 1978, Preliminary report on the ophiolites of northern and western Alaska, in Coleman, R. G., and Irwin, W. P., eds., North American ophiolites: Oregon State Dept. Geology and Mineral Industries Bull. 95, p. 51-58.

Kigluaik and Bendeleben faults, Seward Peninsula By Travis Hudson and George Plafker

The Kigluaik and Bendeleben faults, located in south-central Seward Peninsula, together define a normal fault system that is about $175 \mathrm{~km}$ long (fig. 27). The two faults are 65 and $90 \mathrm{~km}$ long respectively, trend approximately eastwest, are subparallel but not overlapping, and have opposite senses of displacement. Displacements along these faults are responsible for important late Cenozoic regional geomorphic and structural relations on Seward Peninsula; surface features indicative of Holocene displacement are present. Surface features along the faults were studied in the field during July 1977 as part of the Alaska Geologic Earthquake Hazards Project in order to understand better the recent displacement history of the faults and to clarify further the regional tectonic setting of the fault system.

The Kigluaik fault marks the abrupt northern boundary of the rugged Kigluaik Mountains. Along its central part the fault separates the 


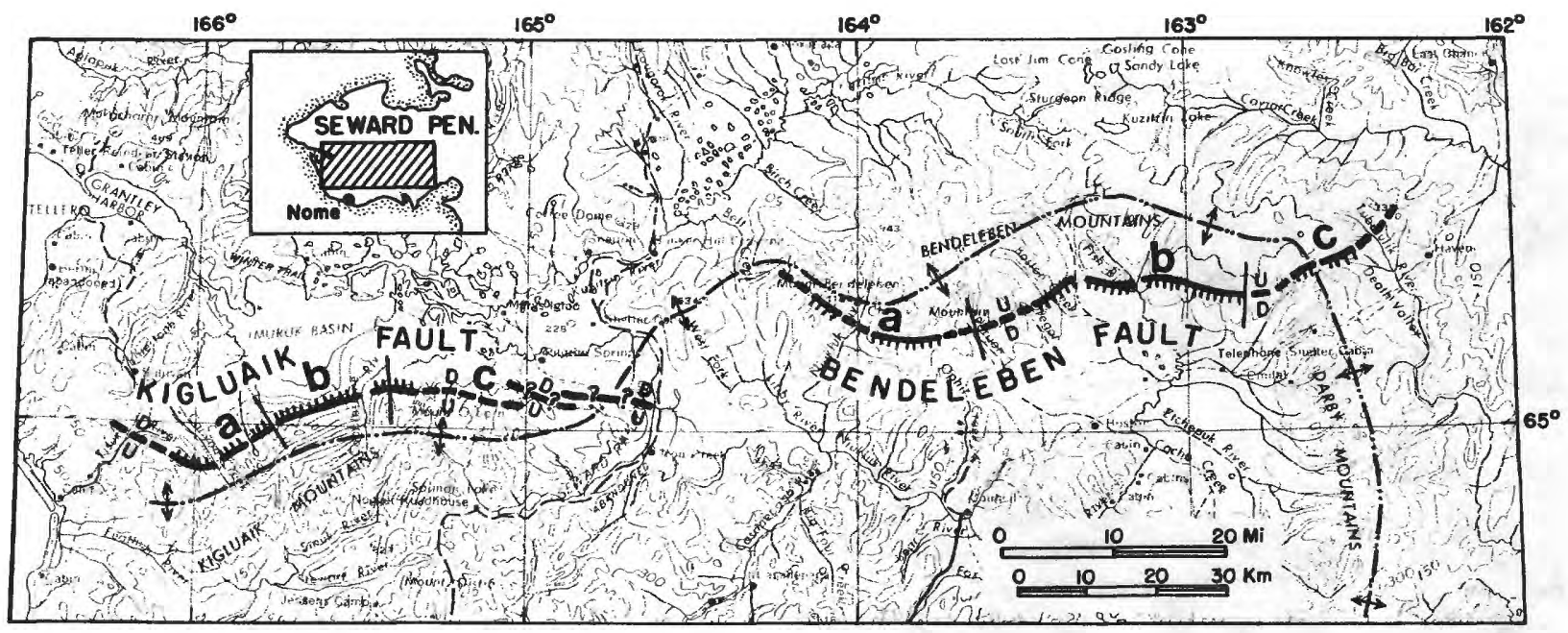

FIGURE 27.-Location of the Kigluaik and Bendeleben faults, Seward Peninsula, Alaska. Hachured where fault well defined by surface features; dashed where poorly defined; queried where inferred. Letters indicate segments discussed in text. Axis of Kigluaik-Bendeleben-Darby Mountains shown by dash-dot line.

mountains from the adjacent lowlands of Imuruk Basin. The fault is consistently down to the north and has a slightly convex northward orientation except near its western limit where it changes strike to a northwesterly direction. Some surface features and geologic relations along the fault are summarized separately below for the western, central, and eastern segments.

Along the western segment of the Kigluaik fault (segment a, fig. 27), the surface trace is marked by distinct slopebreaks in bedrock ridges, mantled by lateral moraine, that trend northerly, parallel to major glaciated valleys. Where exposed, bedrock on both sides of the fault is biotite-feldspar-quartz schist with some granitic dikes and sills. Foliation in the bedrock is approximately parallel to the fault except west of Martha Creek, where the fault apparently dies out near the Nome-Teller road. The bedrock ridges are mostly mantled by lateral moraine, and the fault transects them at elevations commonly greater than $305 \mathrm{~m}$ and as high as $490 \mathrm{~m}$. The most prominent lateral moraines are smooth, moderately sharp crested, and sparsely vegetated, and contain fresh boulders of metamorphic and plutonic rocks; they are probably Wisconsin in age. In some places where the fault trace crosses ridges, a moderately broad notch or swale is developed at the base of the slopebreak. There is usually no distinct fault trace along the floors of the glacial valleys, but one sharp escarp- ment is present between major morainal ridges in the headwaters of White River. At the slopebreaks along the fault trace, surface slopes in lateral moraine are as steep as $17^{\circ}$. Maximum vertical separations range from 4 to about $10 \mathrm{~m}$. Because these separations are measured in the oldest (highest) lateral moraines along this segment, they probably are a reasonable measure of total post-Wisconsin displacement along the fault.

The central segment of the Kigluaik fault (segment $b$, fig. 27) has a surface trace that is very well defined and abruptly separates alluvial, colluvial, and morainal deposits of Imuruk Basin to the north from amphibolite-facies biotite-quartz and biotite-graphite-quartz schist to the south. Foliation in the schist strikes parallel to the fault and dips about $60^{\circ} \mathrm{N}$. A scarp as much as $4 \mathrm{~m}$ high is nearly continuous along the western part of this segment where bedrock is juxtaposed against unconsolidated late Quarternary deposits including small sharp-crested lateral moraines that extend northward from the mouths of steep and narrow valleys. Along the eastern part of the segment, the fault transects extensive morainal deposits of the Cobblestone River valley; the scarp is as much as $6.2 \mathrm{~m}$ high in the highest lateral moraines just east of the valley (elevation about $230 \mathrm{~m}$ ). Total post-Wisconsin displacement may be between 4 and $7 \mathrm{~m}$ along this segment. 
The eastern segment of the Kigluaik fault (segment c, fig. 27) is less well defined than segments farther west. For about $18 \mathrm{~km}$ east of the headwaters of Grand Union Creek, the mountain front is abrupt and characterized by complex morainal deposits at the mouths of moderatesize glacial valleys. These morainal deposits have irregular surfaces and are banked up against metamorphic and granitic bedrock of the mountain front. Lateral moraine thinly caps some bedrock ridges south of the fault, but most of the morainal deposits lie north of and adjacent to the fault. The irregular and youthful glacial deposits, some of which are probably late Wisconsin, obscure this segment of the fault trace. Nevertheless, the trace is reasonably well defined by slopebreaks and notches in morainal ridges and colluvium along the mountain front. East of Pass Creek the mountain front shifts northward in two en echelon steps from the main trace of the fault, which apparently dies out in bedrock a few kilometers east of Pass Creek. The east end of the Kigluaik fault thus appears to be an en echelon system of at least three faults that mark the northern front of the mountain range. The two supposed en echelon members northeast of the main trace do not have surface features clearly indicative of young displacement; the first marks a moderately abrupt mountain front, whereas the second is more subdued. The general geomorphic features suggest that displacement of western en echelon fault segments is younger than on eastern segments.

The Bendeleben fault extends from near Mt. Bendeleben eastward to the headwaters of the Tubutulik River along the south flank of the Bendeleben Mountain (fig. 27). The fault is consistently down to the south and has a generally convex southward surface trace with local shifts in strike, particularly along the central part. Some surface features and geologic relations along the fault are outlined below for the western, central, and eastern segments.

The western segment of the Bendeleben fault (section a, fig. 27) has a surface trace marked by slopebreaks, scarps, and saddles in colluvium overlying bedrock. Bedrock includes a variety of metasedimentary rocks, but lithologic contrasts are common across the fault and small granitic intrusions are mostly on the north side. Slopebreaks and scarps are locally degraded and as much as $4 \mathrm{~m}$ high. No distinct surface trace is evident in the alluvial deposits of the main valleys - the age of recent surface features along this segment is not known.

The central segment of the Bendeleben fault (section b, fig. 27) is characterized by a discontinuous scarp and separates the Bendeleben Mountains from the lowlands of the upper Fish River drainage system (McCarthy's Marsh). The scarp is most evident between the valleys of $\mathrm{Ba}$ ker Creek and Lava Creek. It is developed in colluvium, moraine, and the bedrock of the mountain front, but does not transect the younger alluvial fans and stream deposits. The scarp ranges in height from about $2 \mathrm{~m}$ to more than $8 \mathrm{~m}$ and becomes more degraded with increasing height.

The eastern segment of the Bendeleben fault (section c, fig. 27) crosses, at almost right angles, the main axis of the Bendeleben and Darby Mountains (fig. 27). The surface trace is similar in general features to the western segment of the fault and is marked by discontinuous slopebreaks, benches, and saddles in colluvium overlying bedrock. Bedrock north of the fault includes foliate granodiorite and amphibolitefacies gneissic schist and biotite-quartz schist, whereas south of the fault bedrock includes epizonal to hypabyssal felsic intrusive rocks and slaty to schistose metasedimentary rocks. Mylonitized granodiorite and porphyry are juxtaposed at one locality. This segment is not known to displace moraine or alluvium, but east of the axis of the Bendeleben and Darby Mountains it approximately defines the topographic break between the Bendeleben Mountains and the alluviated lowlands of Death Valley. No surface expression of the fault was observed east of the eastern most Bendeleben Mountains.

In summary, the Kigluaik and Bendeleben faults are major normal faults that are about 65 and $90 \mathrm{~km}$ long, respectively, have opposite senses of displacement but do not overlap, and together define a fault system about $175 \mathrm{~km}$ long. Both apparently die out in bedrock at their eastern and western terminations, and both have surface features indicative of Holocene displacement that are best developed along their central parts. Late Cenozoic displacement along these faults is largely responsible for development of the higher and more rugged parts of the Kigluaik and Bendeleben Mountain ranges and the adjacent lowlands that represent sedimen- 
tary basins (Barnes and Hudson, 1977). Total post-Wisconsin displacement may be about 6 to $7 \mathrm{~m}$ on the central Kigluaik fault and about $8 \mathrm{~m}$ on the central Bendeleben fault.

The Kigluaik and Bendeleben faults are the principal active faults of Seward Peninsula and have large amounts of late Cenozoic dip-slip displacement. Other normal faults with sizeable late Cenozoic displacement are associated with uplift of the Kigluaik, Bendeleben, and Darby Mountains (Hudson, 1977; Barnes and Hudson, 1977), but surface features indicative of recent movements have not been identified along them. It appears that the Kigluaik and Bendeleben faults are the most recently active of many major Seward Peninsula faults. These faults, together with offshore faults west of Teller (Sainsbury, 1972) and west of Cape Krusenstern in the Chukchi Sea (Ettreim and others, 1977), serve to identify a broad region of major late Cenozoic normal faulting. This region is also characterized by widespread late Cenozoic basaltic volcanism (Hudson, 1977) and is considered to reflect a regional stress regime that is characterized by north-south extension. The areal extent of this regime and the history of faulting within it are not well known. Some of the late Cenozoic basaltic volcanic rocks of Seward Peninsula that are presumably related to extensional tectonics are as old as 5.7 m.y. (Hopkins and others, 1971), which suggests that development of the present stress regime began at least as early as the late Miocene.

\section{REFERENCES CITED}

Barnes, D. F., and Hudson, Travis, 1977, Bouguer gravity map of Seward Peninsula, Alaska: U.S. Geol. Survey Open-File Report 77-796-C, scale 1:1,000,000.

Ettreim, Steven, Grantz, Arthur, and Whitney, O. T., 1977, Tectonic imprints on sedimentary deposits in Hope basin, in Blean, K. M., ed., The United States Geological Survey in Alaska; accomplishments during 1976: U.S. Geol. Survey Circ. 751-B, p. B100-B103.

Hopkins, D. M., Mathews, J. O., Wolfe, J. A., and Silberman, M. L., 1971, A Pliocene flora and insect fauna from the Bering Strait region: Paleogeography, Paleoclimatology, Paleoecology, v. 9, p. 211-231.

Hudson, Travis, compiler, 1977, Geologic map of Seward Peninsula, Alaska: U.S. Geol. Survey Open-File Report 77-796-A, scale $1: 1,000,000$.

Sainsbury, C. L., 1972, Geologic map of the Teller quadrangle, western Seward Peninsula, Alaska: U.S. Geol. Survey Map $I-685$, scale $1: 250,000$.
Preliminary investigations of coal outcrops near Farewell, Alaska

By Ernest G. Sloan, Gerald B. Shearer, James Eason, and Carl Almquist

The purpose of this reconnaissance investigation is to determine the extent and quality of coal cropping out along the north front of the Alaska Range between Big River and the boundary of Mount McKinley National Park (area 8, fig. 2). Most of the area is covered with coarse granular sediments deposited unconformably over sedimentary rocks of Tertiary age. Rare bedrock outcrops occur in river bluffs and small stream valleys where the surficial deposits have been eroded sufficiently to expose the underlying bedrock. Outcrops of coal were found in exposures along the little Tonzona River, the upper tributary creeks (unnamed) of Deep Creek, and along Windy Fork of the Kuskokwin River. Thin, discontinuous beds of coal were found along the Big River.

Twelve seams of coal at least $1 \mathrm{~m}$ thick crop out along the Little Tonzona River in sec. $27, \mathrm{~T}$. 31 N., R. 20 W., Seward Meridian. These coal seams range in thickness from 1.0 to $7.9 \mathrm{~m}$ and total $40.3 \mathrm{~m}$ of coal in an 85-m outcrop. Beds strike N. $73^{\circ} \mathrm{E}$. and dip $47^{\circ}$ to $63^{\circ}$ northwest. A 6.3-m coal seam striking N. $50^{\circ}$ E. to N. $60^{\circ} \mathrm{E}$. and dipping $48^{\circ}$ to $55^{\circ}$ west crops out in sec. 13 , T. 30 N., R. 20 W., Seward Meridian, on the bank of an unnamed tributary of Deep Creek. Nine coal seams more than $1 \mathrm{~m}$ thick crop out on Windy Fork in sec. 19, T. 27 N., R. 26 W., Seward Meridian. These seams range in thickness from 1 to $10.5 \mathrm{~m}$ and total $32.9 \mathrm{~m}$ of coal in an $83.6-\mathrm{m}$ outcrop section. Beds strike N. $23^{\circ}$ E. to N. $30^{\circ}$ W. and dip $37^{\circ}$ to $40^{\circ}$ south. The measured outcrop is part of the southern limb of a syncline that trends through the area.

Proximate and ultimate analyses and tests of physical properties are being conducted on channel samples of the coal.

\section{SOUTHWESTERN ALASKA}

New geologic map of the Goodnews-Hagemeister Island quadrangles region, Alaska

By J. M. Hoare and W. L. Coonrad

A new geologic map covering an area of about $31,000 \mathrm{~km}^{2}$ in southwestern Alaska has recently been compiled at a scale of 1:250,000 (Hoare and Coonrad, 1978) as part of the Alaska Mineral Re- 
source Assessment Program (AMRAP). The map includes the Goodnews and Hagemeister Island quadrangles and parts of the adjoining Bethel, Taylor Mountains, Dillingham, and Nushagak Bay quadrangles. About 75 percent of the area mapped under the aegis of AMRAP is shown in figure 28 at a scale of 1:1,000,000; in figure 29 map units on this small-scale map are described. In figure 29 the units are briefly described and correlated with map units of the larger scale map compiled for AMRAP (Hoare and Coonrad, 1978) and with the 1:1,000,000scale preliminary geologic map of Alaska (Beikman, 1974). Figure 28 is duplicated for convenience as figure 47 at the end of the report.

Rough reconnaissance geologic maps of most of the area had been published previous to this work (Hoare and Coonrad, 1959, 1961a, b; Mertie, 1938, pl. 2). During the earlier geologic mapping, the locations of geologic observations (except for those of J. B. Mertie) were plotted on vertical and oblique aerial photographs because there were no reliable topographic base maps. To make the old data useful in the recent investigation, all the old observations and structural data were replotted on modern 1:63,360-scale base maps which recently became available.

Additional fieldwork would improve the new geologic map, but it is better than the old maps because it is plotted on a modern topographic base and is based on many more field observations and a better geologic understanding. New paleontological data and numerous radiometric age dates have established the absolute and relative ages of the rocks with more certainty. The map has also benefited from interpretation of aeromagnetic data (Griscom, 1978) that has supported, confirmed, and extended geologic interpretations.

During earlier investigations about 75 percent of the rocks were mapped as the Gemuk Group, a large undifferentiated unit containing volcanic and sedimentary rocks ranging in age from Carboniferous through Early Cretaceous (Cady and others, 1955, p. 27-34). A major aim of the recent investigation was to subdivide the Gemuk Group into smaller map units of more limited lithologic character and age range. Very little progress was made in this regard, however, because as the investigation progressed, it became clear that the rocks were more intensely deformed than previously thought and that many Paleozoic and
Mesozoic rocks could not be differentiated except where they contained fossils. On the new geologic map most of the area previously mapped in the Gemuk Group is divided into three parts and mapped as undifferentiated rocks of Paleozoic and Mesozoic age, tuffs and sedimentary rocks of Early Cretaceous age, and volcanic and sedimentary rocks of Jurassic and Early Cretaceous age. Contacts between these units are uncertain and largely interpretive.

A partial list of observations and conclusions made during recent geologic mapping includes the following:

(1) Depositional contacts are rare; most contacts between bedded rocks are faults.

(2) Northeast- and northwest-trending faults have cut the rocks into many fault slices and fault blocks that range in size from a few hundred square meters to several hundred square kilometers.

(3) Radiometric dating shows that the intrusive igneous rocks include layered gabbros and ultramafic bodies of Jurassic age, many granitic stocks of Late Cretaceous and early Tertiary age, a felsic intrusive-extrusive complex of early Tertiary age, and felsic dikes and sills of late Tertiary age.

(4) The mafic and ultramafic rocks on and near Cape Newenham constitute an altered dismembered ophiolite complex.

(5) Evidence indicating right-lateral movement in the Togiak-Tikchik fault zone is provided by horizontal and subhorizontal slickensides developed on shear planes in the fault zone. The shear planes are exposed in small upslope-facing scarps that are parallel to large faults within the fault zone.

(6) Conodonts found in some of the limestones document the first known occurrence of Ordovician rocks in the area. Previously, the nearest known Ordovician rocks were in the Lime Hills about $250 \mathrm{~km}$ to the northeast.

(7) New collections of Devonian fossils show that limestones of Devonian age are more widespread than previously known. The Devonian limestones, like those of Permian age, are commonly tuffaceous and associated with mafic volcanic rocks.

(8) Atomodesma shell fragments are valuable guides to rocks of Permian age because they occur in a variety of rock types and even tiny fragments are readily identifiable in the field. They 


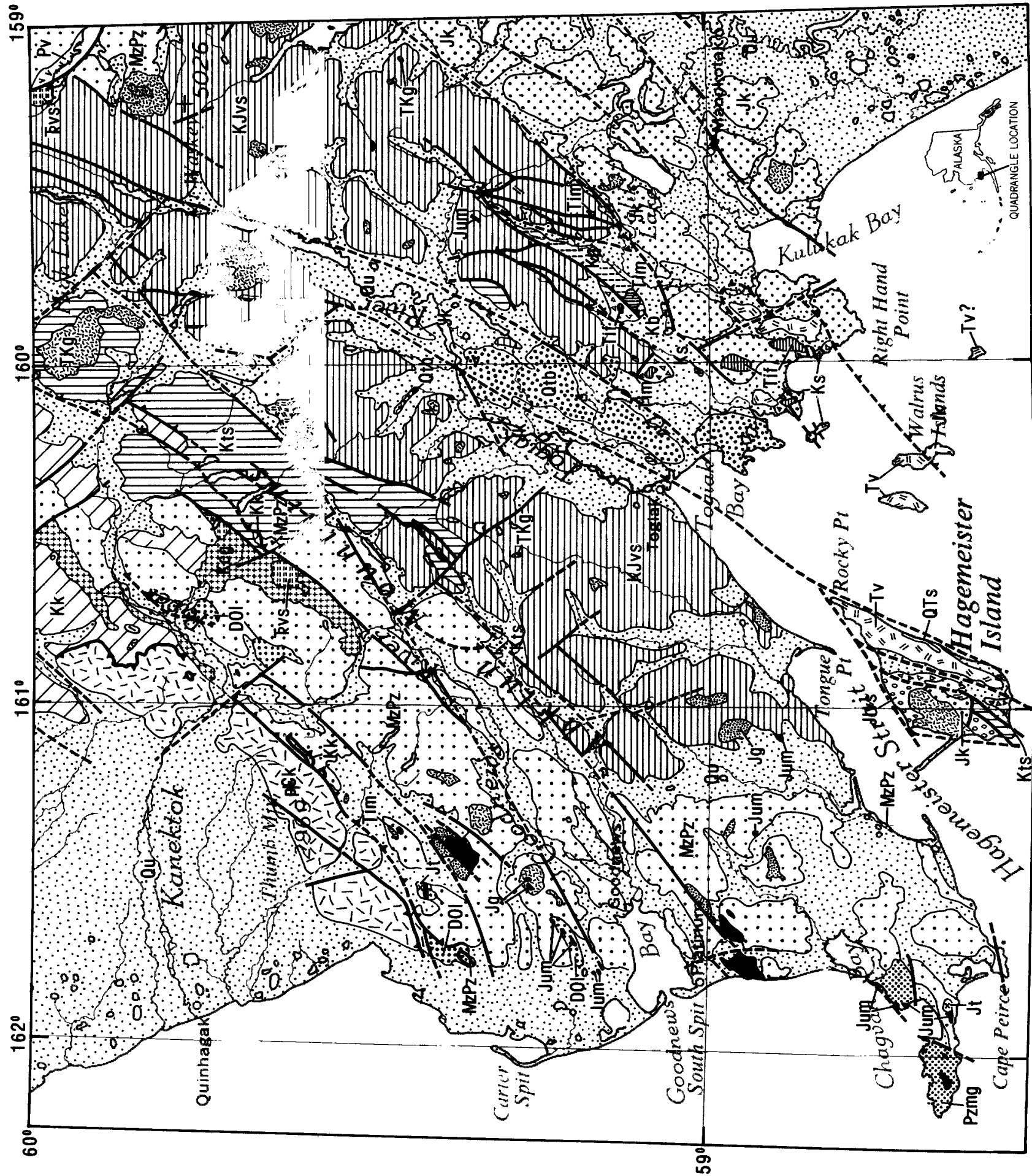




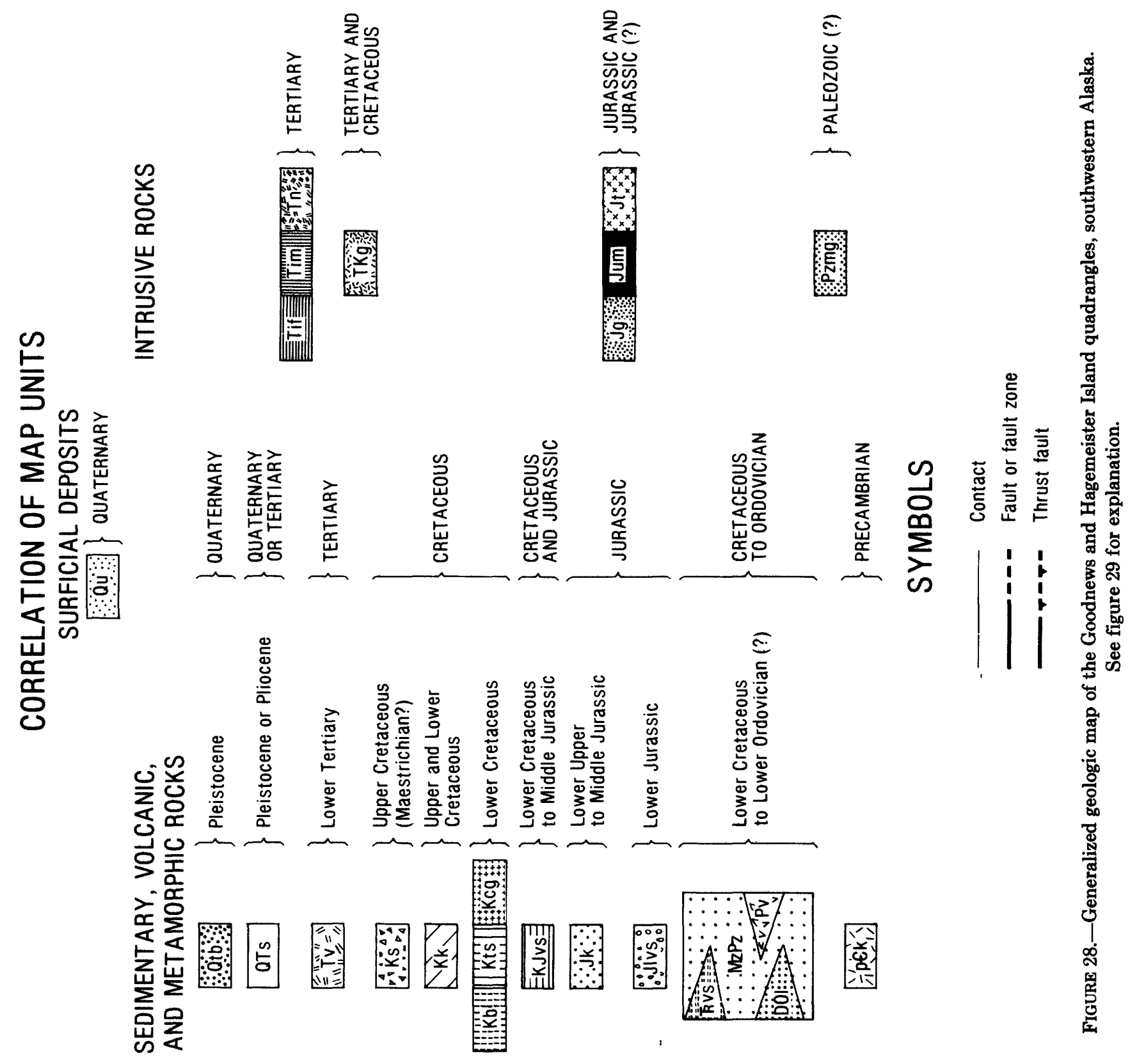




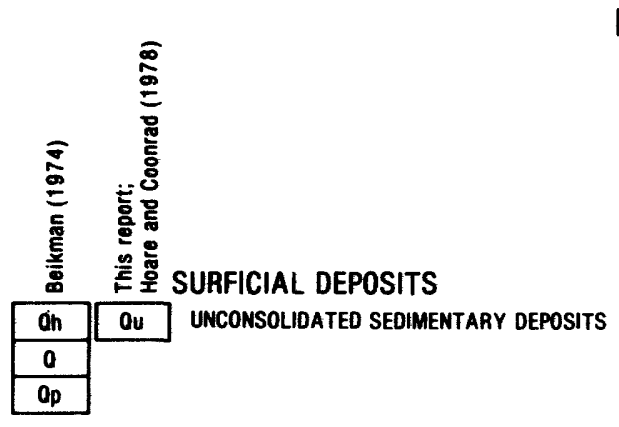

\section{DESCRIPTION OF MAP UNITS}

\section{SEDIMENTARY, VOLCANIC, AND METAMORPHIC ROCKS}

\begin{tabular}{|c|c|}
\hline$\overline{Q v}$ & atb \\
\hline TKv * & OTs \\
\hline TKV & TV \\
\hline MePz & Ks \\
\hline K & Kk \\
\hline \multirow{6}{*}{$\mathrm{MzPz}{ }^{*}$} & $\mathbf{K b}$ \\
\hline & Kts \\
\hline & Kcg \\
\hline & KJvS \\
\hline & Jk \\
\hline & Jlvs \\
\hline
\end{tabular}

BASALT OF TDGIAK RIVER VALLEY

SEMICONSOLIDATED MARINE BEACH DEPOSITS

VOLCANIC ROCKS AND VDLCANOGENIC DEPOSITS - Chiefly andesitic flows and tuff

SEDIMENTARY ROCKS DF SUMMIT ISLAND - Nonmarine conglomerate, sandstone, shale, and carbonaceous mudstone

KUSKOKWIM GROUP - Conglomerate overlain by interbedded graywacke, siltstone, and shale; commonly micaceous; mostly marine

GRAYWACKE OF BUCHIA RIDGE - Chielly interbedded calcareous graywacke, siltstone, and conglomerate with local coquinas of Buchio shells

TUFF AND SEDIMENTARY ROCKS - Varied assemblage of andesitic tuft, graywacke, siltstone, impure limestone, and tuffaceous chert; tuff and tuffaceous sedimentary rocks commonly laumontitized

GRAYWACKE AND COMGLDMERATE - Marine graywacke, siltstone, and conglomerate; commonly calcareous

VOLCANIC AND SEDIMENTARY ROCKS - Interbedded intermediate to mafic flows, tuff, tuffaceous sedimentary rocks, and argillite; tuffaceous rocks commonly laumontitized

GRAYWACKE DF KULUKAK BAY - Chiefly very hard lithic graywacke and siltstone with local conglomerate

VOLCANIC AND SEDIMENTARY ROCKS-Mafic flows and breccias interbedded with volcanogenic sedimentary rocks; fractures commonly coated with laumontite

MtPZ MzPZ

MESOZOIC AND PALEOZDIC ROCKS, UNDIVIDED - Widespread marine unit including volcanic rocks, tuffaceous sedimentary rocks, chert, argillite, siltstone, graywacke, conglomerate, and limestone

\begin{tabular}{|c|c|}
\hline MEPZ * & Rvs \\
\hline pEm & Pv \\
\hline D01 \\
\hline
\end{tabular}

VOLCANIC AND SEDIMENTARY RDCKS - Locally differentiated marine unit of chert, tuffaceous cherty rocks, argillite, siltstone, wacke, conglomerate, limestone, and mafic flows and breccia

VDLCANIC ROCKS-Locally differentiated marine unit of pillow basalt; massive mafic flows, breccia, and tuff

LIMESTONE - Thin-bedded to massive limestone with minor interbedded tuff and mafic flows; locally recrystallized to marble

METAMDRPHIC ROCKS OF KANEKTOK RIVER REGION - Gneiss, schist, amphibolite, and marble; upper greenschist to lower amphibolite facies

INTRUSIVE ROCKS

\begin{tabular}{|c|c|}
\hline $\mathrm{Th}$ & Tif \\
\hline $\mathrm{Tmi}$ & $\mathrm{Tim}$ \\
\hline $\mathrm{TKg}$ & $\mathrm{Tn}$ \\
\hline $\mathrm{Tkg}$ & $\mathrm{TKg}$ \\
\hline $\mathrm{Tkg}$ & $\mathrm{Jg}$ \\
\hline $\mathrm{Um}$ & $\mathrm{Jum}$ \\
\hline $\mathrm{Tkg}$ & * \\
\hline & $\mathrm{Jt}$ \\
\hline
\end{tabular}

FELSIC INTRUSIVE ROCKS-Chiefly rhyolitic to dacitic dikes and sills; locally mapped

MAFIC INTRUSIVE ROCKS - Diabase, basalt, dioritic, and gabbroic dikes and sills locally mapped

IGNEOUS ROCKS DF NAYDRURUN RIVER AREA - Quartz-rich porphyritic felsite intrusive-extrusive complex of dikes, sills, tuff, and breccia

GRANITIC ROCKS - Chiefly quartz monzonite, granodiorite, and quartz diorite stocks

GABBROIC ROCKS-Commonly shows compositional layering

ULTRAMAFIC ROCKS - Serpentinite, dunite, and websterite

TRONDHJEMITE - Associated with serpentinite and gabbro

METAGABBRO AND GREENSTONE- Probable dismembered ophiolite complex of mafic flows, dikes, volcaniclastic rocks, and gabbro altered by greenschist facies metamorphism and metasomatism

* These units previously undifferentiated within map unit indicated

FIGURE 29.-Description of map units for the generalized geologic map of the Goodnews and Hagemeister Island quadrangles (fig. 28), southwestern Alaska. 
are most common in thin-bedded fetid limestones, but also occur as detritus in fine- to coarse-grained clastic rocks including conglomerates.

(9) The identification of radiolarians in 19 out of 119 chert collections helped to define some Mesozoic map units. Elsewhere complex structure and the close association of Mesozoic radiolarians and Paleozoic megafossils made it necessary to map Paleozoic and Mesozoic rocks as one unit.

(10) Rocks of Early Cretaceous age and older are allochthonous and are generally strongly deformed. There are a few isolated fault blocks however, in which the rocks are only mildly deformed. Examples are Buchia Ridge (see Hoare and others, 1975) and Hagemeister Island.

(11) Rocks of late Early Cretaceous (Albian) age to late Late Cretaceous (Maestrichian) age are autochthonous and were derived from nearby source areas. The upper Upper Cretaceous rocks are mostly or entirely nonmarine; the others are mostly shallow-water marine deposits.

(12) Deformation by compression from the southeast probably began in early Mesozoic time and continued into early and middle Cenozoic time. In late Cenozoic time however, the rocks were apparently subjected to tensional forces and a small basalt-floored graben developed in the lower Togiak Valley between the Hagemeister and Togiak-Tikchik faults.

\section{REFERENCES CITED}

Beikman, H. M., 1974, Preliminary geologic map of the southwest quadrant of Alaska: U.S. Geol. Survey Misc. Field Studies Map MF-611, 2 sheets, scale 1:1,000,000.

Cady, W. M., Wallace, R. E., Hoare, J. M., and Webber, E. J., 1955, The Central Kuskokwim region, Alaska: U.S. Geol. Survey Prof. Paper 268, 132 p.

Griscom, Andrew, 1978, Aeromagnetic map and interpretation of the Goodnews and Hagemeister Island quadrangles region, southwestern Alaska: U. S. Geol. Survey Open-File Report 78-9-C, 2 sheets, scale 1:250,000.

Hoare, J. M., and Coonrad, W. L., 1959, Geology of the Bethel quadrangle, Alaska: U.S. Geol. Survey Misc. Geol. Inv. Map I-285, scale 1:250,000.

-1961a, Geologic map of the Hagemeister Island quadrangle, Alaska: U.S. Geol. Survey Misc. Geol. Inv. Map I-321, scale 1:250,000.

1961b, Geologic map of the Goodnews quadrangle, Alaska: U.S. Geol. Survey Misc. Geol. Inv. Map I-339, scale $1: 250,000$.

1978, Geologic map of the Goodnews and Hagemeister Island quadrangles region, southwestern Alaska:
U.S. Geol. Survey Open-File Report 78-9-B, 1 sheet, scale $1: 250,000$.

Hoare, J. M., Coonrad, W. L., Detterman, R. L., and Jones, D. L., 1975, Preliminary geologic map of the Goodnews A-2 quadrangle and parts of the A-2 and B-2 quadrangles, Alaska: U.S. Geol. Survey Open-File Report 75308,1 sheet, scale $1: 63,360$.

Mertie, J. B., Jr., 1938, The Nushagak district, Alaska: U.S. Geol. Survey Bull. 903, 96 p.

Lawsonite in southwestern Alaska

By J. M. Hoare and W. L. Coonrad

Lawsonite has recently been identified at two places in southwest Alaska (fig. 30 ) in the vicinity of previously reported (Hoare and Coonrad, 1977) blue amphibole localities. The only other reported lawsonite locality in Alaska is also associated with blue amphiboles and is on the northwest coast of Kodiak Island (Carden and Forbes, 1976). The Kodiak locality and the blue amphibole localities are alined parallel to, and a short distance northwest of, the Border Ranges fault, which is interpreted as a Mesozoic plate boundary (MacKevett and Plafker, 1974). It seems reasonable to suggest that the lawsonite and blue amphibole occurrences in southwestern Alaska may be related to an older suture zone of probable early Mesozoic age.

The lawsonite and blue amphibole localities on Cape Newenham and Cape Pierce are in, or are closely associated with, a dismembered ophiolite complex consisting of metasomatized roddingitized gabbro, massive greenstones, fine-grained volcaniclastic rocks, pillow lavas, plagiogranite, and serpentine. The complex is part of a broad, poorly defined belt of highly deformed rocks that trends north and northeast from Cape Newenham along the southeast side of an allochthonous terrane of Precambrian gneisses and schists. The rocks in the belt are chiefly volcanic and sedimentary rocks of Paleozoic and Mesozoic (Triassic) age, extensively overlain by Mesozoic sedimentary rocks toward the northeast. The belt contains many isolated tectonic blocks, ultramafic rocks, layered gabbro, plagiogranite, and two other blue amphibole localities. Potassium-argon age determinations made on hornblende from two gabbro bodies and on hornblende at the contact between a large body of ultramafic rock and the country rocks (F. H. Wilson and J. G. Smith, written commun., 1977) indicate that the mafic and ultramafic rocks are of Early Jurassic age. 


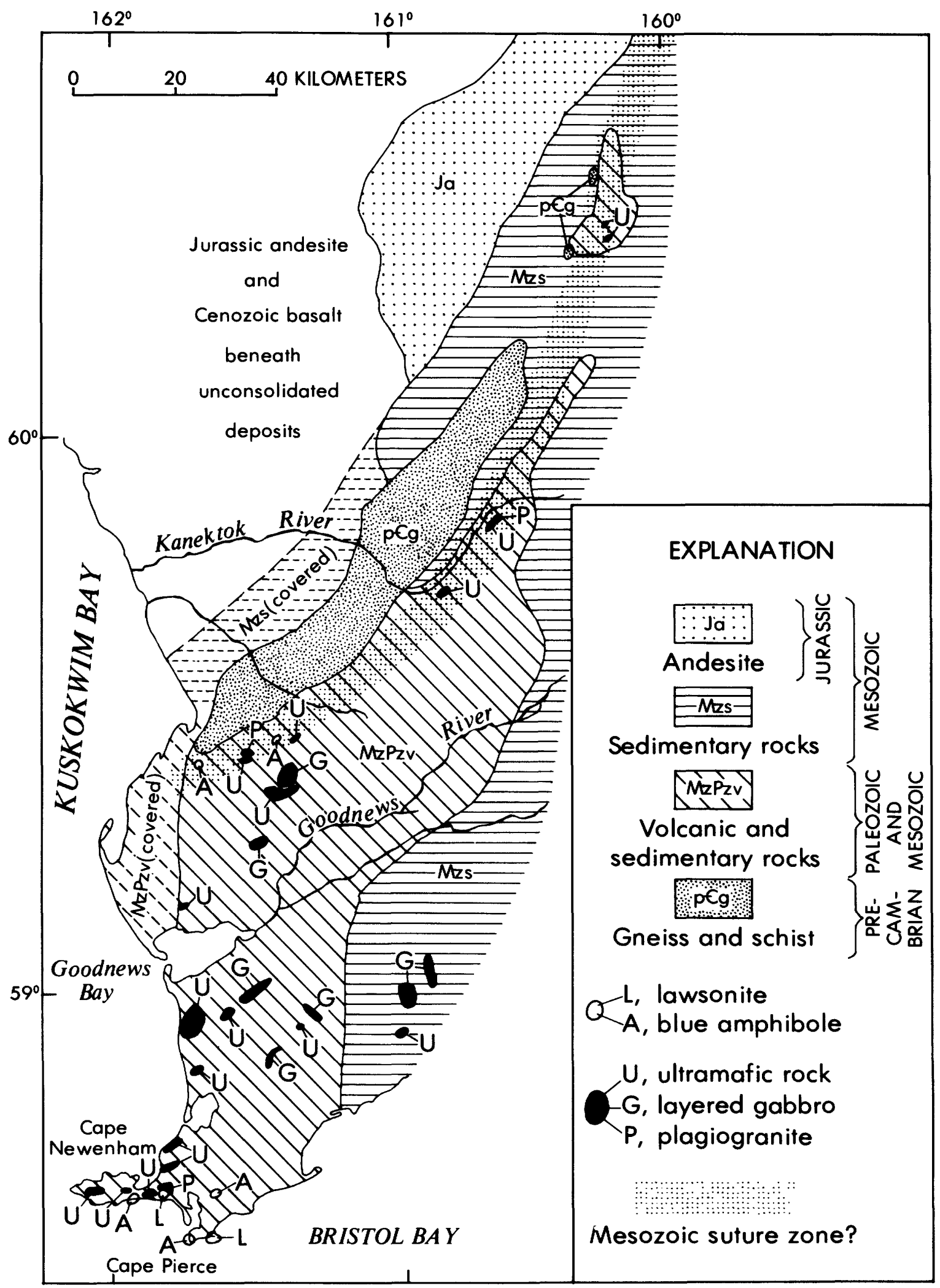

FIGURE 30.-Geologic sketch map showing lawsonite and blue amphibole localities and possible suture zone in southwestern Alaska. 
The presence of high-pressure minerals and the ophiolitic character of the mafic and ultramafic rocks in this belt of highly tectonized rocks suggest that the belt may be related to a major tectonic feature such as an old suture zone. The assumed location and trend of the suture zone southeast of the Precambrian metamorphic terrane are based on alined exposures of serpentine and structural observations which indicate that the metamorphic terrane has been tectonically transported southeastward, whereas the Paleozoic and Mesozoic rocks to the southeast have moved northwestward on southeast-dipping thrust faults. From the metamorphic terrane south to Cape Newenham, structural trends are northeast and there are several southeast-dipping reverse faults. No north-trending faults that might be interpreted as an old suture zone have been recognized. Moreover, it seems unlikely that the suture zone would bend abruptly southward parallel to the seacoast. A more reasonable suggestion is that the suture zone arcs gently southwestward toward the Pribilof Islands where a large body of serpentinized ultramafic rocks is exposed (Barth, 1956).

\section{REFERENCES CITED}

Barth, T. F. W., 1956, Geology and petrology of the Pribilof Islands, Alaska: U.S. Geol. Survey Bull. 1028-F, $64 \mathrm{p}$.

Carden, J. R., and Forbes, R. B., 1976, Discovery of blueschists on Kodiak Island, in Short notes on Alaskan geology: Alaska Div. Geol. and Geophys. Surveys Geol. Rept. 51, p. 19-22.

Hoare, J. M., and Coonrad, W. L., 1977, Blue amphibole occurrences in southwestern Alaska, in Blean, K. M., ed., The United States Geological Survey in Alaska; accomplishments during 1976: U.S. Geol. Survey Circ. 751-B, p. B39.

MacKevett, E. M., Jr., and Plafker, George, 1974, The Border Ranges fault in south-central Alaska: U.S. Geol. Survey Jour. Research, v. 2, no. 3, p. 323-329.

Upper Jurassic and Cretaceous rocks of the Kamishak Hills-Douglas River area, lower Cook Inlet

By Leslie B. Magoon, Robert M. Egbert, and George Petering

The Kamishak Hills-Douglas River area is located $350 \mathrm{~km}$ southwest of Anchorage in southwestern Alaska (fig. 31). The sedimentary rocks in and adjacent to this area range in age from
Late Jurassic through Oligocene and represent the youngest outcropping rock on the northwest flank of the Cook Inlet basin. Regionally, these rocks dip gently to the southeast, occasionally interrupted by faults and dip reversals. This report discusses only the Upper Jurassic through Cretaceous rocks that crop out in the area shown on the geologic map (fig. 31). The geologic map is based on six weeks of fieldwork done during the summers of 1975 and 1977 and revises the map by Magoon, Adkison, and Egbert (1976).

The Naknek Formation (fig. 31) is known to exist in a northeast-trending belt from the Alaska Peninsula to the Talkeetna Mountains (Burk, 1965; Keller and Reiser, 1959; Detterman and Hartsock, 1966; Grantz, 1960). The Naknek Formation consists of conglomerate to siltstone, but thin-bedded very fine grained fossiliferous sandstone predominates. Field identification is aided by the presence of Buchia sp.; units overlying the Naknek are most reliably differentiated by distinctive faunal assemblages. The Naknek Formation, which contains several intraformational unconformities, can be mapped throughout the area although the base of the formation is not exposed. Unnamed Lower Cretaceous rocks overlie the Naknek Formation with a very slight angular unconformity.

The Naknek Formation also occurs in the Katmai area adjacent to Lake Grosvenor, west of the area of this report (Keller and Reiser, 1959, p. 271). Fossils collected throughout the Katmai area indicate a Late Jurassic (Oxfordian through early Portlandian) age and include Buchia concentrica, B. mosquensis, and B. rugosa; however, the Naknek Formation from the Iniskin-Tuxedni area to the northeast is only as young as early Kimmeridgian (Imlay and Detterman, 1973).

The presence of the unnamed Lower Cretaceous rocks in the Kamishak Hills was first reported by Parkinson (1960), and an incomplete section was measured and described by Jones and Detterman (1966) (sections 4 and 5 on fig. 31). They described two units-a lower unit of "gray shale and siltstone with many calcarenite interbeds . . containing abundant, mostly fragmented, valves of Inoceramus," (p. D54), and an upper unit of "rusty-weathering, brownish-gray, benonitic shale and siltstone that bears fossiliferous calcareous concretions." (p. D54). The age of the lower unit is late Hauterivian to early Barremian; the upper unit is Barremian (Jones and 


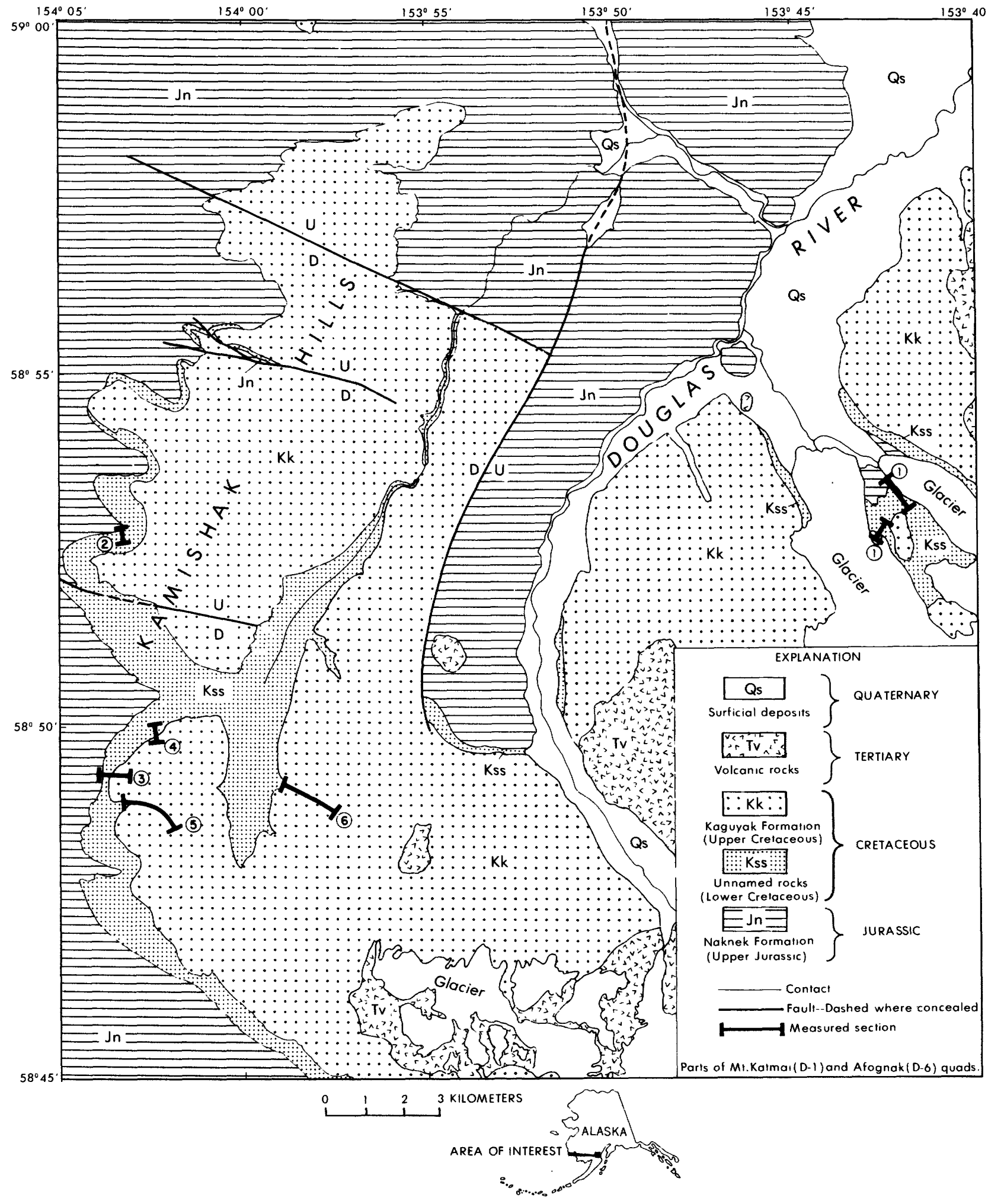

FIGURE 31.-Geologic map of the Kamishak Hills-Douglas River area, southwestern Alaska. 
Detterman, 1966). The lower unit correlates with the Nelchina Limestone in the Chitina Valley and the Herendeen Limestone of the Alaska Peninsula; the upper unit contains the first occurrence of fossils of definite Barremian age in Alaska (Jones and Detterman, 1966). Complete sections (1 and 3, fig. 31) of the unnamed Lower Cretaceous rocks were measured by the authors in 1975 and 1977. The additional section measured in the lower unit consists of a basal sandstone, up to $15 \mathrm{~m}$ thick, that is rich in Inoceramus prisms and belemnites; the upper unit contains sandstone channels. Modal analyses indicate that sandstone in this unit is arkosic, similar to the Naknek Formation except for the presence of large numbers of Inoceramus prisms (Lankford and Magoon, 1978). Field identification of these Lower Cretaceous rocks is based on these distinctive lithologies and fossils. PostCretaceous faults of less than $15 \mathrm{~m}$ displacement have been mapped in the northwest part of the area (fig. 31). Block slides and slumps of $\mathrm{Ka}$ guyak Formation rest on the upper shale unit throughout the area. The unnamed Lower Cretaceous rocks are almost $215 \mathrm{~m}$ thick in both section 1 and section 3 (fig. 31). These rocks, including the basal sandstone, thin by erosion to the northwest until the Kaguyak Formation rests unconformably on the Naknek Formation. Erosional remnants of the unnamed Lower Cretaceous rocks exist near the truncated edge. The Kaguyak Formation overlies the unnamed Lower Cretaceous rocks with a distinct angular unconformity.

The Kaguyak Formation, named and described by Keller and Reiser (1959, p. 273) for exposures in the vicinity of Kaguyak $20 \mathrm{~km}$ south of the Kamishak Hills-Douglas River area, is of Late Cretaceous age. Sections 4 and 5 (fig. 31) contain Pachydiscus (Pachydiscus) kamishakensis Jones of Maestrichtian age (Jones and Detterman, 1966). Section 6 contains the most complete basal section. This section comprises as much as $305 \mathrm{~m}$ of ammonite- and Inoceramusrich sandstone with some interbedded siltstone; the upper $170 \mathrm{~m}$ of section is gray siltstone similar to the lower part of the type section of the Kaguyak Formation. Modal analyses indicate that the basal sandstone of the Kaguyak Formation is similar to the Naknek Formation (Lankford and Magoon, 1978). In the northwest part of the Kamishak Hills, the lower $3 \mathrm{~m}$ of the Kaguyak Formation is a pebble conglomerate containing thick-shelled pelecypods and abraided Lower Cretaceous belemnites. The base of the Kaguyak Formation is mapped at the first occurrence of ammonites, thick-shelled pelecypods, conglomerate, and sandstone containing whole or nearly whole shells of Inoceramus sp. In places stratigraphic relations are obscured by small faults, landslides, or intrusions of Tertiary igneous rock. The Kaguyak Formation presumably covered the entire Kamishak Hills-Douglas River area prior to post-Cretaceous erosion (probably pre-West Foreland time).

\section{REFERENCES CITED}

Burk, C. A., 1965, Geology of the Alaska Peninsula-Island arc and continental margin: Geol. Soc. America Mem. 99, (part 1), 250 p.

Detterman, R. L., and Hartsock, J. K., 1966, Geology of the Iniskin-Tuxedni region, Alaska: U.S. Geol. Survey Prof. Paper 512, 78 p.

Grantz, Arthur, 1960, Geologic map of Talkeetna Mountains (A-2) quadrangle, Alaska and the contiguous area to the north and northwest: U.S. Geol. Survey Misc. Geol. Inv. Map I-313, scale 1:48,000.

Imlay, R. W., and Detterman, R. L., 1973, Jurassic paleobiogeography of Alaska: U.S. Geol. Survey Prof. Paper 801, 34 p.

Jones, D. L., and Detterman, R. L., 1966, Cretaceous stratigraphy of the Kamishak Hills, Alaska Peninsula, in Geological Survey research 1966: U.S. Geol. Survey Prof. Paper 550-D, p. D53-D58.

Keller, A. S., and Reiser, H. N., 1959, Geology of the Mount Katmai area, Alaska: U.S. Geol. Survey Bull. 1058-G, p. 261-298.

Lankford, S. M., and Magoon, L. B., 1978, Petrography of the Upper Jurassic through Oligocene sandstones in the Cape Douglas-Kamishak Hills area, lower Cook Inlet, in Johnson, K. M., ed., The United States Geological Survey in Alaska; accomplishments during 1977: U. S. Geol. Survey Circ. 772-B, p. B60.

Magoon, L. B., Adkison, W. L., and Egbert, R. M., 1976, Map showing goelogy, wildcat wells, Tertiary plant-fossil localities, $\mathrm{K}$-Ar age dates and petroleum operations, Cook Inlet area, Alaska: U.S. Geol. Survey Misc. Geol. Inv. Map I-1019, 3 sheets, scale $1: 250,000$.

Parkinson, L. J., 1960, Cretaceous strata of the Cape Douglas area, Alaska Peninsula, Alaska [abs.]: Geol. Soc. America Bull., v. 71, no. 12, pt. 2, p. 2087. 
Petrography of the Upper Jurassic through Oligocene sandstones in the Cape DouglasKamishak Hills area, lower Cook Inlet By Stephen M. Lankford and Leslie B. Magoon

Sandstones were collected for thin sections from five stratigraphic units in the Cape Douglas-Kamishak Hills area of lower Cook Inlet during the summers of 1975 and 1977. A total of 53 thin sections were cut from sandstones that range in age from Late Jurassic through Oligocene and include the Naknek Formation (Burk, 1965), unnamed Lower Cretaceous rocks (Jones and Detterman, 1966), Kaguyak Formation (Keller and Reiser, 1959), West Foreland Formation, Hemlock Conglomerate, and the lower part of the Tyonek Formation (Magoon and others, 1976). The grain size of these poorly sorted sandstones ranges from very fine to medium. Using a petrographic microscope, 300 points per slide were counted using a $1-\mathrm{mm}$ grid for very fine- to fine-grained sandstones and a 2-mm grid for medium-grained sandstones. The data include porosity and the amount and type of quartz, feldspar, lithic fragments, shell fragments, mafic components, matrix, and cement. Microcrystalline quartz grains similar to chert were counted as lithic fragments because many include plagioclase and other minerals, and a few grade into aphanatic volcanic lithic fragments. The type of matrix was recorded using the classification of Dickinson (1970).

The sandstone composition of the Naknek Formation and the unnamed Lower Cretaceous rocks is summarized on a Q-F-L diagram (fig. 32 ). The average normalized compositions of these units are $Q_{36} F_{60} L_{4}$ and $Q_{38} F_{59} L_{3}$, respectively, on the basis of 17 thin sections that plot midway between the quartz and feldspar end numbers. Caicite grains in sandstone in the unnamed Lower Cretaceous rocks are fragmented Inoceramus prisms as much as $3 \mathrm{~mm}$ long. These prisms were not included in the Q-F-L diagram even though they are present in amounts from less than 1 to as high as 70 percent. The mafic minerals include hornblende and mica; the content of total mafic minerals averages about 2 percent. Diagenetic matrix in these sandstones consists predominantly of phyllosilicate in thin rims separating detrital grains. In the Naknek Formation authigenic minerals include quartz overgrowths, chlorite, sericite, and some laumon- tite. In unnamed Lower Cretaceous rocks in which detrital calcite approaches 70 percent, only 2 percent diagenetic matrix is present, but the matrix increases to as much as 32 percent in samples without detrital calcite. Unlike the Naknek Formation, the unnamed Lower Cretaceous rocks contain significant amounts of secondary calcite cement, probably from recrystallized detrital calcite.

Data from the Kaguyak Formation form two fields on the Q-F-L diagram. The basal sandstone that unconformably overlies the unnamed Lower Cretaceous rocks and the Naknek Formation form the first field, and the upper sandstone forms the second. Eight samples from the basal sandstone have an average composition of $\mathbf{Q}_{33} \mathbf{F}_{55} \mathbf{L}_{12}$, showing a slight enrichment in volcanic lithic fragments compared to the underlying units. Twelve samples from the upper sandstone are rich in lithic fragments and have an average composition of $Q_{27} F_{32} L_{41}$. The quartz grains show undulatory extinction. The mafic minerals include trace amounts of mica, but no hornblende. Matrix cement (epimatrix) in the upper sandstone consists of decomposed lithic fragments.

Data on the West Foreland Formation form a scattered field near the volcanic lithic fragment end member. The average composition of the sandstone from the West Foreland is $Q_{29} F_{22} L_{49}$. The quartz grains show undulatory extinction, as in the Kaguyak Formation, and mafic minerals occur in trace amounts. Matrix cements (orthomatrix and epimatrix) are diagenetically altered volcanic lithic fragments.

Data on the Hemlock Conglomerate and the lower part of the Tyonek Formation are undifferentiated because both units are late Oligocene in age and of similar composition. These rocks form a tight, uniform field of data with an average composition of $Q_{39} F_{24} L_{37}$. Quartz grains, showing undulatory extinction, are abundant, and many samples average almost 2 percent mica, mostly biotite.

Burk (1965) displayed the grain composition of coeval units from the Alaska Peninsula on a Q-F-L diagram in which quartz and chert are included on the same end member. His data on the Upper Jurassic and Lower Cretaceous units (Naknek Formation, Staniukovich Formation, and Herendeen Limestone) compare very well with the data presented here for similar units. 


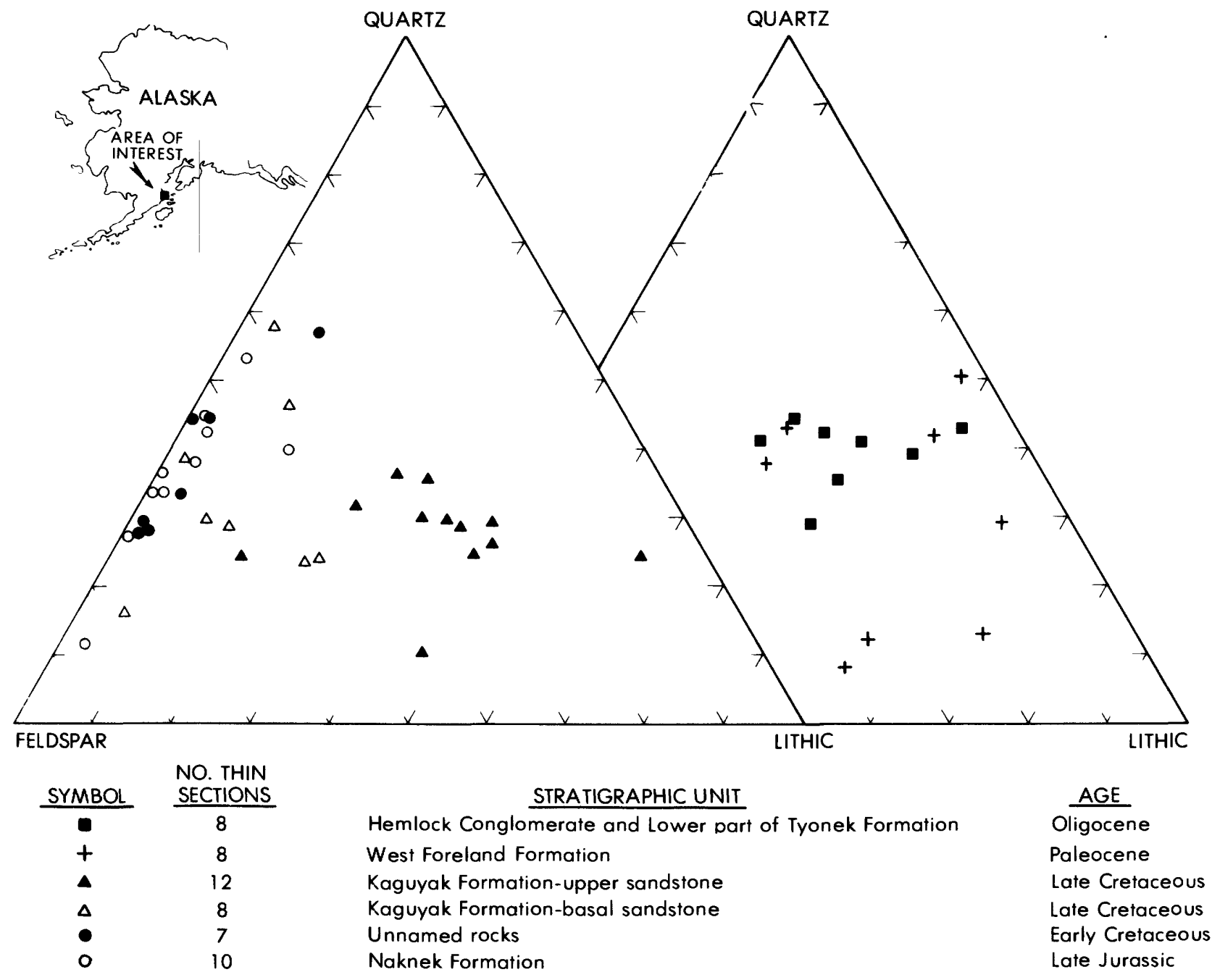

FIGURE 32.-Q-F-L diagrams, Upper Jurassic through Oligocene sandstones, Cape Douglas-Kamishak Hills area, southern Alaska.

Burk's data for Upper Cretaceous (Chignik Formation) rocks show lithic fragments ranging in abundance from 25 to 80 percent. As this study shows, the upper sandstone of the Kaguyak Formation also contains abundant lithic fragments.

Stewart (1976) presented data on Tertiary rocks from the Middle Ground Shoal State No. 1 well in upper Cook Inlet and from the Cape Douglas area. Recalculating Stewart's Q-F-L data so that chert is included as a lithic fragment, the West Foreland Formation has an average composition of $Q_{19} F_{26} L_{55}$ and $Q_{24} F_{17} L_{59}$, respectively, from the two areas. The undifferentiated Hemlock Conglomerate and Tyonek Formation has an average composition of $Q_{55} F_{16} L_{29}$. Stewart's data compare well with data in this study. Winkler (1978) examined 28 thin sections of sandstones collected from the Chickaloon and Arkose Ridge Formations in the Matanuska Valley and Talkeetna Mountains. The Chickaloon is coeval with the West Foreland Formation. Only the sandstone from the Chickaloon Formation, whose average composition is $Q_{22} F_{20} L_{58}$, compares favorably with the West Foreland Formation. The average composition of the Arkose Ridge Formation is $Q_{35} F_{57} L_{8}$. The similarity of its composition to that of the underlying granitic pluton suggests a local, rather than regional, source. The sandstone compositions of the Naknek Formation, unnamed Lower Cretaceous rocks, and from the basal part of the Kaguyak Formation compare favorably with the sandstone composi- 
tions of the Arkose Ridge Formation.

In conclusion, the Naknek Formation and the unnamed Inoceramus-rich Lower Cretaceous rocks appear to have originated from a granitic source. The overlying basal sandstone of the Kaguyak Formation was derived from these older units and from the same granitic source. The upper sandstone of the Kaguyak Formation contains abundant volcanic lithic fragments, probably a result of extensive volcanic activity. The same or another period of volcanism in the early Tertiary contributed significant amounts of lithic material to the West Foreland formation, whereas the undifferentiated Hemlock Conglomerate and Tyonek Formation contains more quartz and fewer volcanic lithic fragments.

\section{REFERENCES CITED}

Burk, C. A., 1965, Geology of the Alaska Peninsula-Island arc and continental margin (part 1): Geol. Soc. America Mem. 99, 250 p.

Dickinson, W. R., 1970, Interpreting detrital modes of graywacke and arkose: Jour. Sed. Petrology, v. 40, p. 695-707.

Jones, D. L., and Detterman, R. L., 1966, Cretaceous stratigraphy of the Kamishak Hills, Alaska Peninsula, in Geological Survey research 1966: U.S. Geol. Survey Prof. Paper 500-D, p. D53-D58.

Keller, A. S., and Reiser, H. N., 1959, Geology of the Mount Katmai area, Alaska: U.S. Geol. Survey Bull. 1058-G, p. 261-298.

Magoon, L. B., Adkison, W. L., and Egbert, R. M., 1976, Map showing geology, wildcat wells, Tertiary plant-fossil localities, K-Ar age dates and petroleum operations, Cook Inlet area, Alaska: U.S. Geol. Survey Misc. Inv. Map I-1019, 3 sheets, scale $1: 250,000$.

Stewart, R. J., 1976, Turbidites of the Aleutian abyssal plain; Mineralogy, provenance, and constraints for Cenozoic motion of the Pacific Plate: Geol. Soc. America Bull., v. 87, p. 793-808, 14 figs.

Winkler, G. R., 1978, Framework grain mineralogy and provenance of Arkose Ridge and Chickaloon Formation sandstones, Matanuska Valley, in Johnson, K. M., ed., The United States Geological Survey in Alaska; accomplishments during 1977: U. S. Geol. Survey Circ. 772-B, p. B70.

Interpretation of depositional environments in the Chignik Formation, Alaska Peninsula

By Robert L. Detterman

The Upper Cretaceous Chignik Formation is being studied as part of the Alaska Mineral Resource Assessment Program (AMRAP) in the
Chignik and Sutwik Islands quadrangles $(1: 250,000)$ (area 9, fig. 2). The formation is of particular interest in that porous sandstones, where they were cut by intrusive rock, permitted circulation of mineral-bearing fluids and now locally contain anomalous concentrations of base metal sulfides. These same porous sandstones are also of interest as potential reservoir rock for oil and gas, and the formation contains numerous coal beds.

The Chignik Formation was named and described by Atwood (1911, p. 41-48) from exposures along the shore of Chignik Bay; the type section was designated along Whalers Creek, near the head of Chignik Lagoon. Burk (1965) recognized both marine and nonmarine rocks in the formation-the marine beds overlie his nonmarine Coal Valley Member.

A section on the northwest shore of Chignik Lagoon was measured in detail in July 1977; this is probably the section referred to by Atwood (1911, p. 41-48). The $490-\mathrm{m}$ section is almost completely exposed between Boomers Cove and the sandspit at the mouth of Chignik Lagoon; erosion has removed the top. The beds unconformably overlie the Naknek Formation (Upper Jurassic).

The depositional environment of the rocks at this locality is cyclic nearshore marine to nonmarine; three complete cycles and a part of a fourth are represented in the exposed beds. The last of the fourth cycle is missing, probably owing to erosion. The cycles are of approximately the same thickness, ranging from 106 to $137 \mathrm{~m}$.

In the first cycle, which is $122 \mathrm{~m}$ thick, a dark siltstone deposited offshore rests unconformably on the Naknek Formation. This deposit is overlain by a clean, crossbedded sandstone interpreted as an offshore bar with a paleoccurrent direction of southwest to northeast. The overlying beds are massive sandstone representing foreshore and shoreface deposits. They contain numerous coquina layers of large thick-shelled pelecypods including Inoceramus, Glycymeris, Ostrea, Pecten, and numerous smaller pelecypods including Anomia. The fossils have not yet been completely identified, so other genera may be present. The shells are very abundant, and nearly all are disarticulated. Thin, dark siltstone with abundant carbonaceous debris and thin coat seamlets overlies the shoreface sandstone and is interpreted as a coastal plain deposit. The 
siltstone is extensively burrowed. The top of the siltstone is channeled and overlain by a dark carbonaceous sandstone, probably a distributary channel deposit; this sandstone completes the first cycle.

A slight marine transgression initiated the second cycle, which includes $60 \mathrm{~m}$ of thin olive-gray to yellow-brown sandstone and siltstone probably deposited in a lagoon. These deposits are overlain by a shoreface sandstone and $23 \mathrm{~m}$ of fluvial sandstone and conglomerate with largescale crossbedding, numerous channels, climbing ripple marks, and thin interfluvial shale deposits with coal beds.

The third cycle starts with $60 \mathrm{~m}$ of massive sandstone with minor conglomerate representing foreshore and shoreface deposits. These beds contain numerous shell layers with the same general pelecypod fauna as lower in the section, but with the addition of large Canadoceras and Neodesmoceras ammonites. The largest specimen noted was approximately $.43 \mathrm{~m}$ across. These beds are overlain by about $45 \mathrm{~m}$ of thin dark- to medium-gray lagoonal siltstone and sandstone containing a few Inoceramus, but a different species than found lower in section. Both the foreshore and lagoonal deposits are extensively burrowed; Diplocraterion- and Skolithos-type burrows are the most commonly found. The nonmarine part of this cycle is only $25 \mathrm{~m}$ thick and consists of fluvial channel sandstone and conglomerate with point-bar crossbedding.

All of the upper $125 \mathrm{~m}$ representing the incomplete fourth cycle is massive marine sandstone and conglomerate with a few interlayed siltstone beds; these deposits are interpreted as foreshore to shoreface deposits. These beds are extensively burrowed, mainly with Skolithos-type burrows, and contain a few Inoceramus shells.

The depositional environment of the Chignik Formation is considerably more complex than originally believed (Atwood, 1911; Martin, 1926; Knappen, 1929; and Burk, 1965). The cyclic nearshore-to-continental, high-energy environment produced numerous massive sandstone and conglomerate beds that have good to fair visual porosity and good sorting. These beds are potential reservoir rock for oil and gas.

The Chignik Formation is considered Late Cretaceous (Campanian) in age (Jones, 1963; Burk, 1965). The abundant fossils collected dur- ing this investigation probably will not greatly change this designation, but should increase the number of genera reported from the formation.

\section{REFERENCES CITED}

Atwood, W. W., 1911, Geology and mineral resources of parts of the Alaska Peninsula: U.S. Geol. Survey Bull. 467, 137 p.

Burk, C. A., 1965, Geology of the Alaska PeninsulaIsland arc and continental margin (Pt. 1): Geol. Soc. America Mem. 99, 250 p.

Jones, D. A., 1963, The Upper Cretaceous (Campanian and Maestrichtian) ammonites from southern Alaska: U.S. Geol. Survey Prof. Paper 432, 53 p.

Knappen, R. S., 1929, Geology and mineral resources of the Aniakchak district, Alaska: U.S. Geol. Survey Bull. 797, p. F161-F227.

Martin, G. C., 1926, The Mesozoic stratigraphy of Alaska: U.S. Geol. Survey Bull. 776, 493 p.

New ages on intrusive rocks and altered zones on the Alaska Peninsula

By F.H. Wilson, R.L. Detterman, and M.L. Silberman

Preliminary potassium-argon dating of intrusive rocks and altered zones in the Chignik and Sutwik Island quadrangles of the Alaska Peninsula seems to indicate at least three and possibly four Tertiary ages of alteration and mineralization.

At Bear Creek Mining Company's Bee Creek prospect, in the Chignik C-2 quadrangle (fig. 33 ), the samples completely studied so far indicate a mineralization or alteration age of about $3.7 \mathrm{~m} . \mathrm{y}$. An amphibole from an altered sample of one of the original plutons has an apparent age near 7 m.y. Additional samples of various phases of the alteration assemblage are being dated.

Dates on secondary biotite and biotite and potassium-feldspar in late pegmatites in the pluton at Warner Bay (Chignik A-2 quadrangle) possibly indicate a mineralization age of $6.5 \mathrm{~m} . \mathrm{y}$. Work is also in progress on an unaltered sample of this pluton from another locality to determine the original emplacement date.

Two dates from the prospect at Mallard Duck Bay (Chignik A-2 quadrangle) suggest two distinct ages of alteration. Amphibole from a chloritized dike intruding strongly propylitically altered rocks has an apparent age near $32 \mathrm{~m}$.y. If this dike postdates the alteration, as the field relations suggest, then a sample of phyllically altered rock (quartz-sericite) collected about $1 \mathrm{~km}$ 


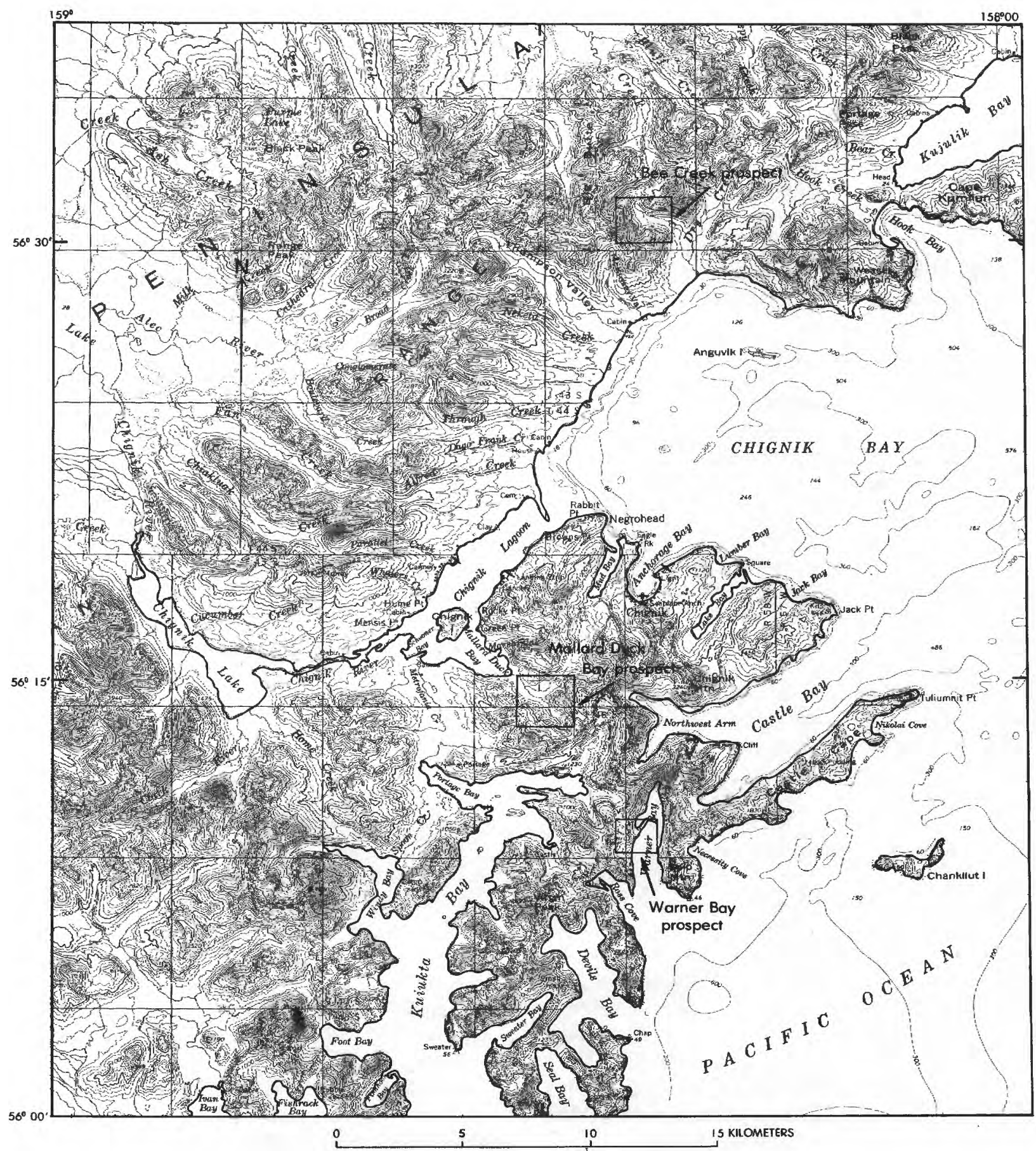

FIGURE 33.-Location map, potassium-argon studies in Chignik and Sutwik Islands quadrangles.

downstream in the same large altered zone indicates another alteration event at approximately 21 m.y. The dike has a definite intrusive contact with the altered rocks it intrudes; however, no other samples as yet indicate any older alteration events in this or other areas. Work in progress is expected to resolve these questions.

A sample of a biotite-dacite from the west end of Sutwik Island has yielded a biotite age of 35.5 m.y. This hypabyssal intrusive body is not defi- 
nitely associated with any alteration, though there are abundant small alteration zones in the immediate vicinity.

Finally, a granitic cobble collected from an outcrop of conglomerate in the Chignik Formation along the south shore of Chignik Lagoon has yielded a minimum age of $92 \mathrm{~m} . \mathrm{y}$.

Tertiary sedimentary rocks of the Alaska Peninsula between Pavlof Bay and False Pass; their geology and petroleum potential

By Hugh McLean

Unmapped areas of the outermost part of the Alaska Peninsula contain late Tertiary marine and nonmarine sedimentary rocks, capped by volcanic flows, and intruded by numerous andesitic dikes and sills. Gently folded sedimentary rocks between False Pass and Morzhovoi Bay (fig. 34) consist mainly of nonmarine and shallow-marine sandstone, mudstone, and conglomerate. Locally, these strata contain molluskan assemblages of Miocene age. The rocks were derived largely from a volcanic source terrane. Rapid facies changes, both lateral and stratigraphical, suggest a paleogeographic setting similar to the present peninsula in which active volcanic centers supply sediment to nearby fluvial and shallow-marine environments.

Sedimentary rocks farther to the northeast, between Cold Bay and Pavlof Bay, include marine and nonmarine volcaniclastic rocks ranging in age from Oligocene through Pleistocene. Mollusks of Oligocene age were found in the Belkofski Formation. Kennedy and Waldron (1955), who named the formation, reported that it contained only plant fossils. Burk (1965) suggested a possible age equivalence of the Belkofski to his Eocene Tolstoi Formation on the basis of marine megafossils. Most of the Belkofski Formation, however, is nonmarine, consisting mainly of volcanic sandstone with thin beds of black carbonaceous mudstone. The upper part of the formation contains a flora of broad deciduous leaves and conifer needles. Strata in much of the area between Cold Bay and Belkofski Bay were provisionally mapped as Bear Lake (?) Formation by Burk (1965). These strata should be mapped as the Belkofski Formation; the Belkofski is unconformably overlain by weakly consolidated Pliocene and Pleistocene fluvial gravels capped in turn by probable Pleistocene andesitic and basaltic lava flows.
Mollusks of probable Miocene age were collected from sandstone beds on the south shore of Ukolnoi Island located near the entrance to Pavlof Bay. These marine strata are probably correlative with the Bear Lake Formation. As is common in many areas of the southwestern Alaska Peninsula, the fossiliferous strata of Ukolnoi Island grade upward into nonmarine volcanogenic sedimentary rocks that are unconformably overlain by volcanic flows of probable Quarternary age.

Small islands and reefs that lie south of the Alaska Peninsula between Sanak Island and Deer Island consist mainly of gently dipping columnar volcanic flows locally interbedded with volcanic breccia and lenses of tuffaceous sedimentary rocks.

The petroleum potential of Neogene sedimentary rocks at the Aleutian end of the Alaska Peninsula is limited by their volcanic provenance and by igneous intrusions including numerous dikes and sills and a small number of quartz diorite stocks that may be comagmatic with some of the volcanic rocks. Petroleum source rocks such as carbonaceous mudstone or marine shale constitute a very small part of the sedimentary record. Most Tertiary sandstone beds can be described as "hard and tight." Low porosity and permeability values are primarily due to high percentages of tuffaceous and(or) argillaceous matrix or to alteration associated with intrusive rocks.

\section{REFERENCES CITED}

Burk, C. A., 1965, Geology of the Alaska Peninsula-Island arc and continental margin: Geol. Soc. America Mem. 99,250 p.

Kennedy, G. C., and Waldron, H. H., 1955, Geology of Pavlof Volcano and vicinity, Alaska: U.S. Geol. Survey Bull. 1028-A, 19 p. [1956].

\section{SOUTHERN ALASKA}

New potassium-argon data on the age of mineralization and metamorphism in the Willow Creek mining district, southern Talkeetna Mountains, Alaska

By Miles L. Silberman, Béla Csejtey, Jr, James G. Smith, Marvin A. Lanphere, and Frederick $H$. Wilson

The now largely abandoned Willow Creek mining district, southern Talkeetna Mountains, Alaska, produced nearly $\$ 18,000,000$ in gold and 


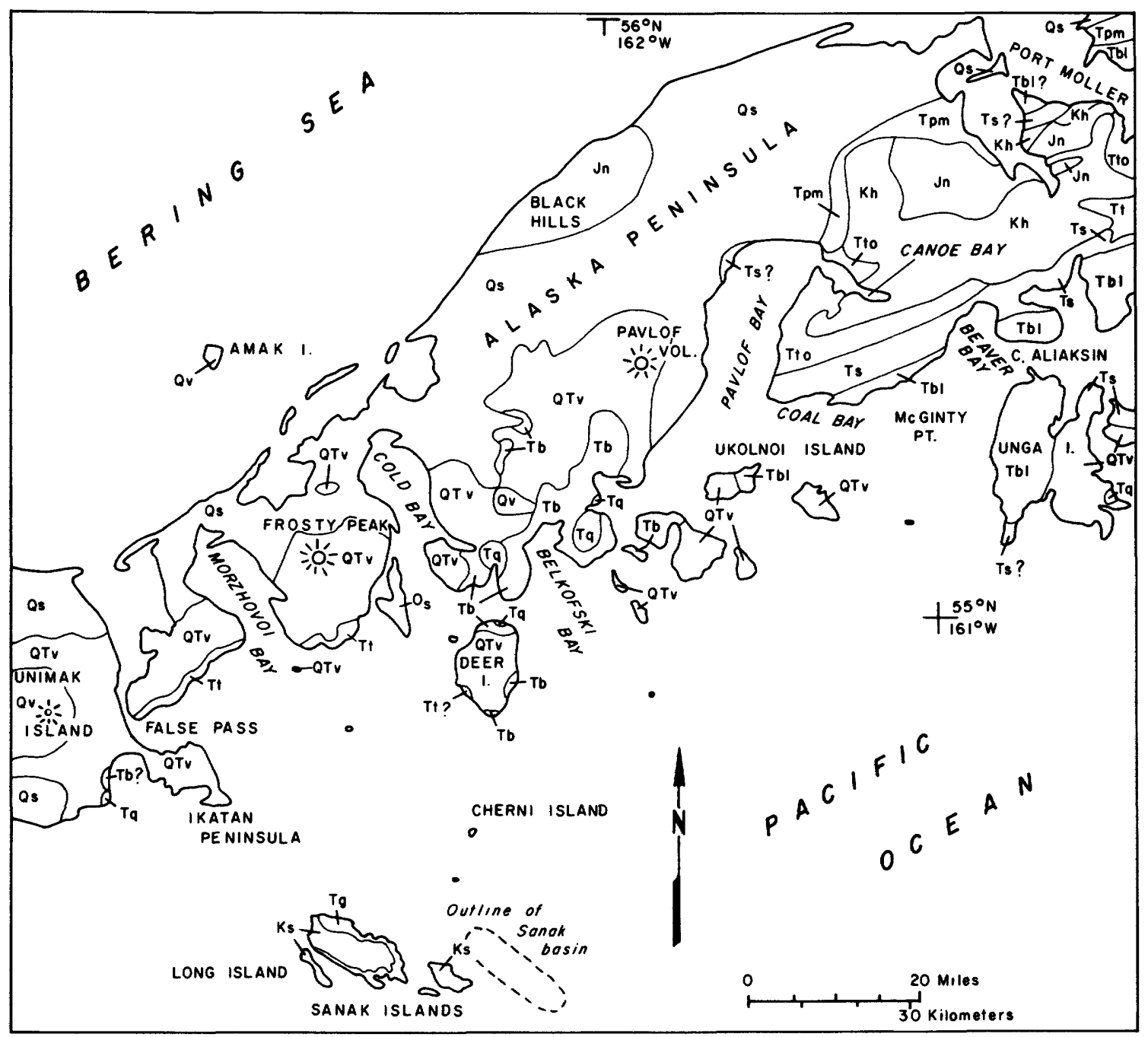

EXPLANATION

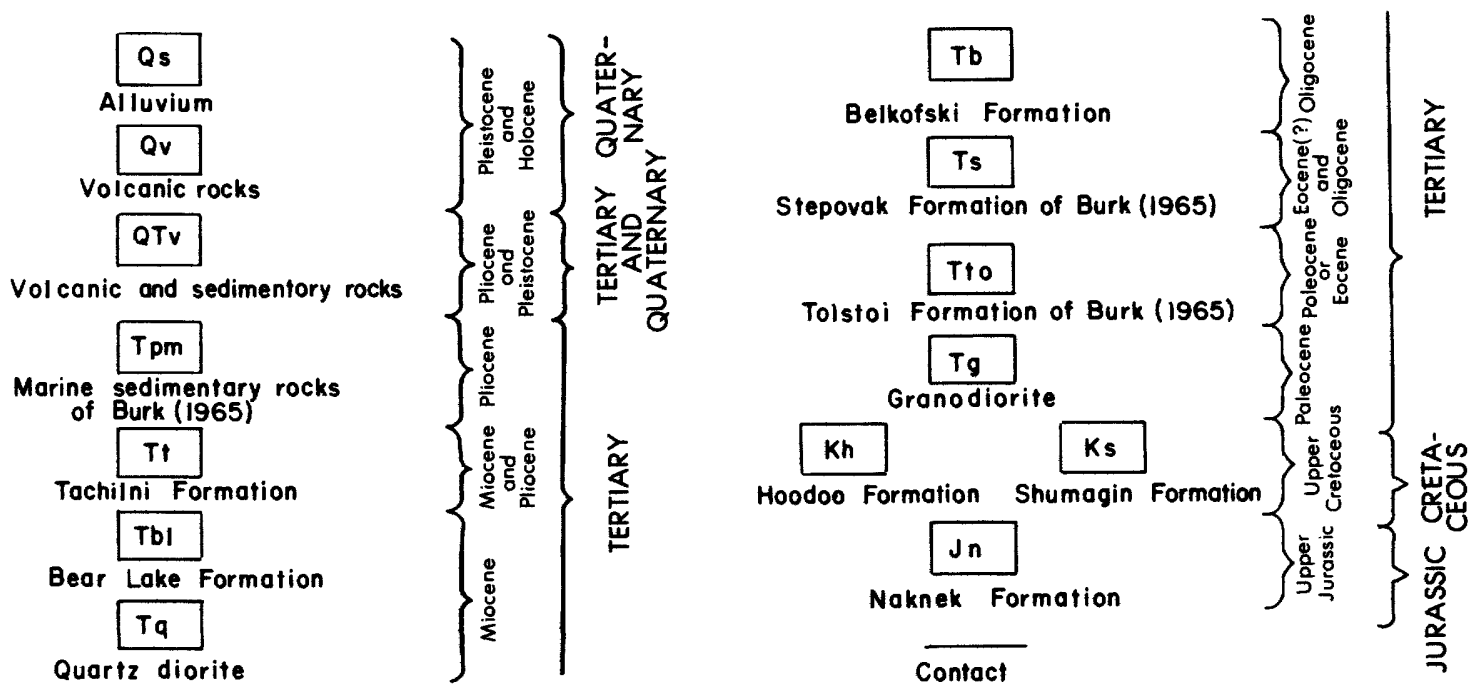

Figure 34.-Geologic map of Alaska Peninsula between Pavlof Bay and False Pass. 
minor silver between 1909 and the early 1950's. Mineralized quartz veins, which contain gold and silver along with minor quantities of base metals (in pyrite, galena, chalcopyrite, sphalerite, molybdenite, and arsenopyrite), cut Late Cretaceous and early Tertiary tonalite and quartzmica schist of probable Jurassic age (Ray, 1954; Silberman and others, 1976; Béla Csejtey, Jr., unpub. data, 1978).

A generalized geologic map of the Willow Creek area (fig. 35) shows the mineralized area in the southwestern part of the area underlain by tonalite and the northern part of that underlain by schist. Most of the district's production came from veins in the tonalite (Ray, 1954). Biotitegranite in the western part of the map area is of about the same age as the tonalite and is probably a more felsic differentiate of the tonalite parent magma (Béla Csejtey, Jr., unpub. data, 1978).

Potassium-argon ages of minerals from samples of tonalite, schist, and metamorphosed ultramafic rocks that intrude the schist are summarized on table 3, and the sample locations are shown on figure 35. Additional potassium-argon data from the Talkeetna Mountains are reported in Csejtey and others (1977). The tonalite and biotite-granite give nearly concordant mineral-pair ages (biotite-hornblende and biotitemuscovite), but these range from 60 to $73 \mathrm{~m}$.y. In the Willow Creek area the range in potassiumargon ages of mineral pairs and single minerals is 70 to $78 \mathrm{~m} . \mathrm{y}$.

The tonalite is mineralogically uniform; mafic materials are hornblende and minor biotite, but grain size varies. Not enough detailed mapping has been done to determine whether this is a single pluton or a series of composite bodies. Ray (1954) indicates that the finer grained tonalite (quartz-diorite of Ray, 1954) occurs near the southern margin and represents a primary feature of a single pluton, the fine grain size in this area being due to proximity of the intrusive margin.

The tonalite intrudes the schist (Béla Csejtey, Jr., unpub. data, 1978; Csejtey and Smith, 1975), but metamorphism of this unit appears to be uniform and unrelated geometrically to the contact with the granitic rock. According to Csejtey and Smith (1975), the schist is a uniform, medium-grained quartz-muscovite-chlorite-albite-minor biotite schist. It is presently green-
TABLE 3.-Potassium-argon ages of granitic rocks, schist, and mineralization, southern Talkeetna Mountains

\begin{tabular}{|c|c|c|c|}
\hline $\begin{array}{l}\text { Location, } \\
\text { fig. } 34\end{array}$ & Rock type & Mineral & Age, m.y. \\
\hline 1 & Tonalite & $\begin{array}{l}\text { Biotite } \\
\text { Hornblende }\end{array}$ & $\begin{array}{l}69 \pm 2.1 \\
73 \pm 2.2\end{array}$ \\
\hline 2 & Tonalite & $\begin{array}{l}\text { Biotite } \\
\text { Hornblende }\end{array}$ & $\begin{array}{l}72 \pm 2.2 \\
74 \pm 2.2\end{array}$ \\
\hline 3 & $\begin{array}{c}\text { Biotite- } \\
\text { granite }\end{array}$ & $\begin{array}{l}\text { Biotite } \\
\text { Muscovite }\end{array}$ & $\begin{array}{l}65 \pm 2.0 \\
67 \pm 2.0\end{array}$ \\
\hline 4 & Tonalite & Biotite & $78 \pm 2.4$ \\
\hline 5 & Schist & Muscovite & $60 \pm 1.8$ \\
\hline 6 & Schist & Muscovite & $66 \pm 2.0$ \\
\hline 7 & Schist & Muscovite & $59 \pm 1.8$ \\
\hline 8 & Serpentinite & Actinolite & $89 \pm 4.5$ \\
\hline 9 & Serpentinite & Actinolite & $91 \pm 4.6$ \\
\hline 10 & $\begin{array}{l}\text { Altered } \\
\text { tonalite }\end{array}$ & Muscovite & $56 \pm 1.7$ \\
\hline
\end{tabular}

schist facies, but relicts of hornblende and garnet, now replaced by chlorite, indicate that it has been retrograded from amphibolite facies (Csejtey and Smith, 1975). The potassium-argon ages of micas from the schist are uniformly lower than those of the tonalite by 5 to $21 \mathrm{~m}$.y. However, two actinolite ages from the metamorphosed mafic rocks, which intrude the schist, yielded concordant results of 91 and 89 m.y., both older than the ages of micas from the tonalite. Amphiboles, in general, retain more argon during post-crystallization thermal events than do muscovites, and their ages probably better represent the time of prograde metamorphism of the schist terrane than do the muscovite dates from the schist itself.

We believe that the whole set of data, particularly the rather large spread of ages in both the schist and the tonalite, indicates argon loss from the minerals caused by a thermal event younger than the emplacement of the tonalite. The schist ages do not reflect simple metamorphism by intrusion of the tonalite since they are younger than ages given by minerals from that unit. $\mathrm{Nu}$ merous dikes and irregular intrusions of aplite, pegmatite, lamprophyre, and diabase intrude the tonalite; these have not yet been dated. Some resetting of parts of the tonalite may have resulted from emplacement of these intrusions if they are younger than the tonalite by a significant 


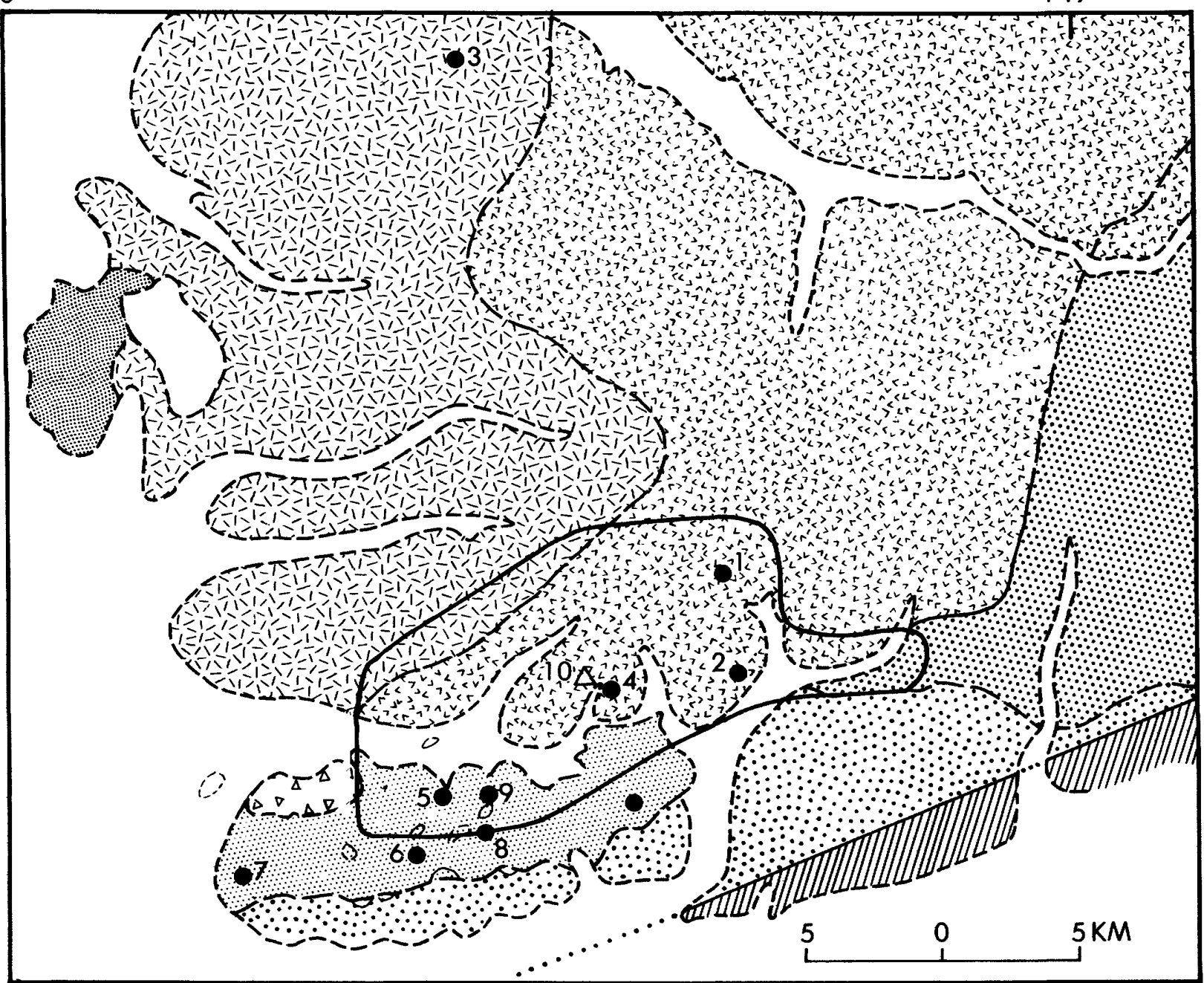

EXPLANATION

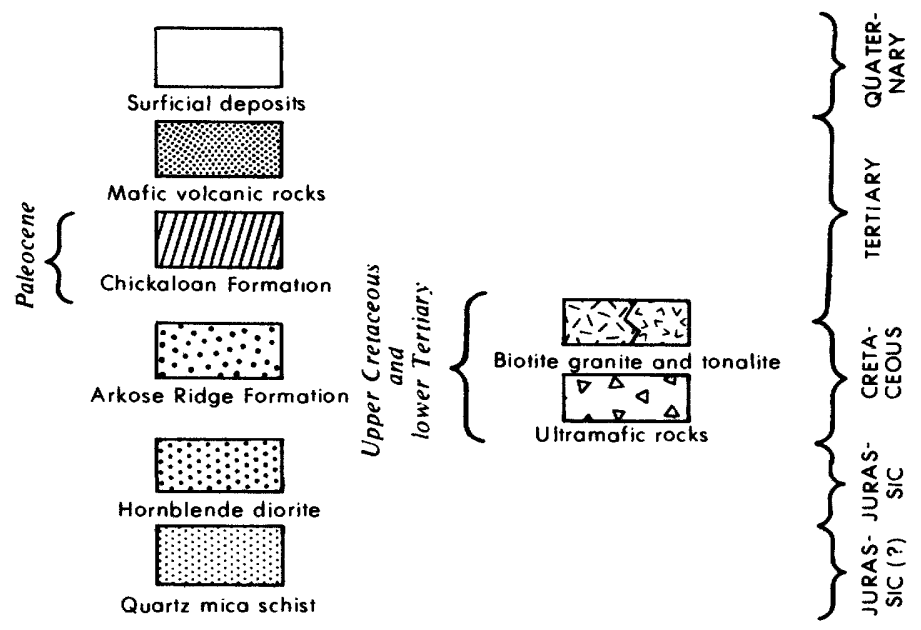

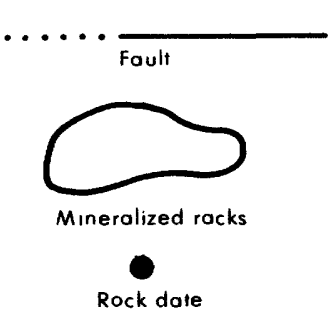

$\Delta$

Mineralization date

FTGURE 35.-Geologic map of the Willow Creek area, southern Talkeetna Mountains, Alaska. 
amount.

Throughout the district, there are wide but irregularly distributed areas of propylitic alteration of the tonalite, including one along the contact with the schist. Narrow (fractions of a meter to several meters) sericitic alteration selvages adjacent to mineralized quartz veins occur in the tonalite. Alteration selvages along crosscutting veins in the schist are characterized by oxidation. However, most cross-cutting veins in the schist are found in faults and shear zones, which are relatively permeable and have probably allowed access of groundwater, causing oxidation of sulfides in the quartz veins. Other veins in the schist appear to be oriented largely along planes of foliation and are without noticeable alteration selvages.

The potassium-argon age of $56 \mathrm{~m}$.y. from muscovite in a quartz-sericite selvage adjacent to a gold-bearing vein at the Bullion mine (fig. 35, location 10 ; table 3 ) suggests a possible source of the thermal episode that has affected the area. Quartz veins are pervasively distributed throughout the tonalite (Ray, 1954) and range from $.01 \mathrm{~m}$ to several meters in thickness. The age of the veins must be confirmed by additional dates determined on other samples, but tentatively we suggest that a mineralization-alteration episode at about 56 m.y. may have reset some of the tonalite ages.

Quartz veins and boudins are very common in the schist. We suggest that some of these, at least, may have formed during the same episode as vein emplacement in the tonalite. The greater effect on the ages of schist may be due to two factors. The greater permeability of the schist owing to its foliation may have allowed more extensive heating of the unit by circulating thermal waters, and the finer grain size of the micas in the schist may have permitted more argon loss than occurred in the coarser grained minerals in the tonalite. The apparently older ages of the actinolites from the metamorphosed mafic rocks may reflect greater argon retentivity in amphiboles than in micas and the lower permeability of the metamorphosed mafic minerals in the schist.

This explanation of the potassium-argon age distribution must be further evaluated by additional age determinations from the veins in both the tonalite and the schist. In addition, stable isotope analyses and fluid-inclusion examination of the veins in the schist and tonalite should be done to determine whether they are of the same origin. An alternative origin for at least some of the veins of the schist is as metamorphic segregations. Analyses are in progress on samples collected to test these possibilities. Other interpretations of these age data are possible, but in our opinion, the data probably represent complex, multistage processes that have affected this area. Apparently the alteration-mineralization episode was late in the sequence.

\section{REFERENCES CITED}

Csejtey, Béla, Jr., Nelson, W. H., Eberlein, G. D., Lanphere, M. A., and Smith, J. G., 1977, New data concerning age of the Arkose Ridge Formation, south-central Alaska, in Blean, K. M., ed., The United States Geological Survey in Alaska; accomplishments during 1976: U.S. Geol. Survey Circ. 751-B, p. B62-B64.

Csejtey, Béla, Jr., and Smith, J. G., 1975, Petrography, tentative age, and correlation of schist, Willow Creek, Talkeetna Mountains, southern Alaska, in Yount, M. E., ed., United States Geological Survey Alaska Program, 1975: U.S. Geol. Survey Circ. 722, p. 48.

Ray, R. G., 1954, Geology and ore deposits of the Willow Creek mining district, Alaska: U.S. Geol. Survey Bull. 1004, $86 \mathrm{p}$.

Silberman, M. L., O'Leary, R. M., Csejtey, Béla, Jr., and Peterson, J. A., 1976, Geochemical anomalies in the Willow Creek mining district, southern Talkeetna Mountains, Alaska: U.S. Geol. Survey Open-File Report 76-191, 5 sheets, scale 1:24,000.

Tectonic significance of newly discovered lower Paleozoic strata in the upper Chulitna Valley, south-central Alaska

By Béla Csejtey, Jr., Willis H. Nelson, David L. Jones, and Norman J. Silbering

Reconnaissance geologic mapping in the Healy A-6 quadrangle disclosed two massive limestone beds of Silurian(?) and Devonian age along the lower course of Long Creek (localities A and B on fig. 36). The two vertical limestone beds, each about $20 \mathrm{~m}$ thick and striking northeasterly, are exposed in the canyon wall of the creek. The limestones are massive to thickly bedded and medium gray, contain numerous shelly fragments, and have undergone only moderate recrystallization. They are enveloped by poorly exposed, dark-gray shale, argillite, and finegrained graywacke. Contacts between the limestone beds and the enveloping rocks are not well enough exposed to determine whether the contacts are depositional or tectonic or a combination of both. Thus, the age of some of the enveloping rocks might differ from that of the li- 

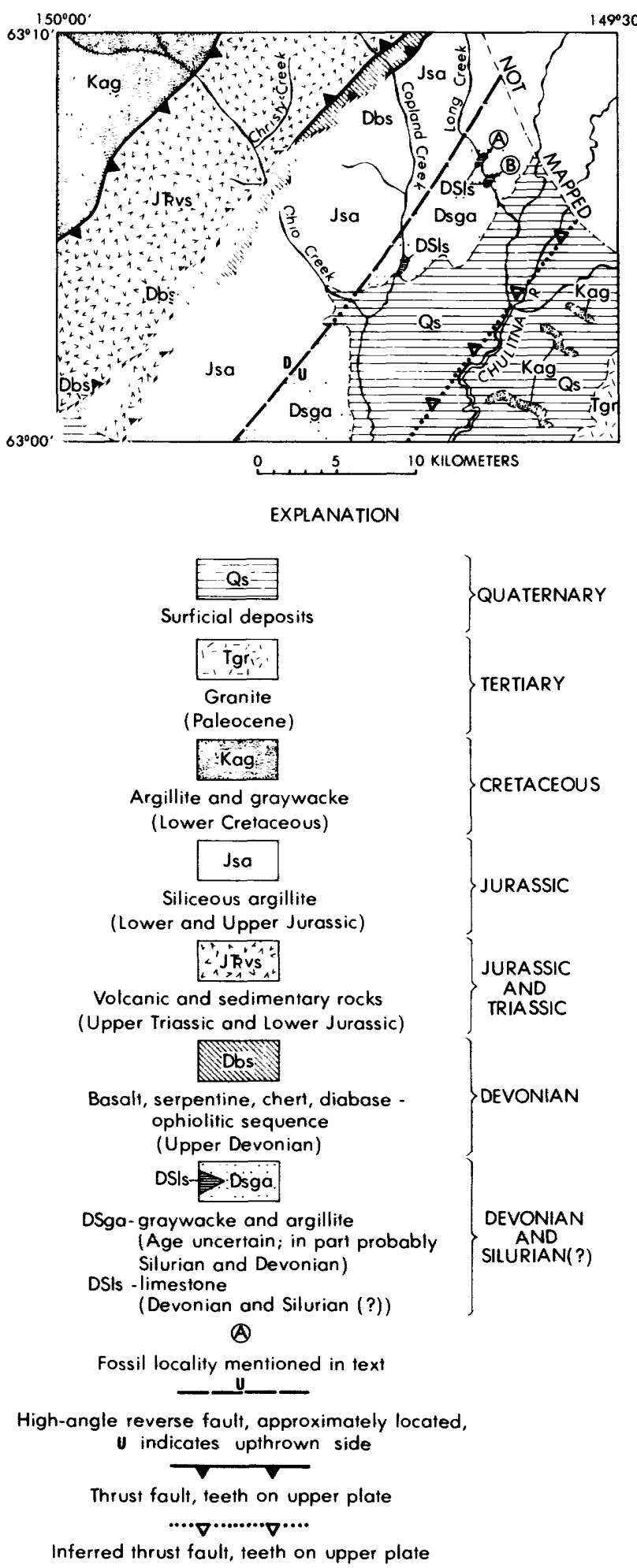

FiguRE 36.-Generalized geologic map of the upper Chulitna Valley area, south-central Alaska. mestones. Fossils from the two limestone beds have been identified by W. A. Oliver, Jr. (written commun., 1977). One of the limestones (locality A, fig. 36) yielded massive stromatoporoids and Dendrostella? sp. of Middle Devonian age. The other bed (locality B, fig. 36) contains Labechia sp. and Favosites sp. of Silurian or Devonian age. Whether the two limestone beds are both of Devonian age, or only one is Devonian and the other is Silurian, cannot be determined on the basis of information presently available.

Lithologic characteristics of the limestones suggest that they were deposited in shallow water, perhaps along an ancient continental margin. These rocks occur only about $6 \mathrm{~km}$ to the east of a narrow belt of basalt, serpentinite, diabase, and chert interpreted to be remnants of a dismembered ophiolite sequence, indicative of deep-water ocean floor deposition (Jones and others, 1977). These ophiolitic rocks have been dated on the basis of conodonts and radiolarians by D. L. Jones (unpub. data, 1978) as Late Devonian in age.

The discovery of the Silurian (?) and Devonian sedimentary rocks in the upper Chulitna Valley is of great tectonic importance. The present proximity of these Paleozoic marginal deposits to ocean floor deposits of slightly younger age is additional evidence for large-scale alpine-type orogenic deformation in south-central Alaska. This orogeny took place in middle to Late Cretaceous time as the result of northward plate motion and suturing of allochthonous terranes to continental rocks that are now part of the North American plate (Csejtey, 1976 and unpub. data; Jones and others, 1977).

\section{REFERENCES CITED}

Csejtey, Béla, Jr., 1976, Tectonic implications of late Paleozoic volcanic arc in the Talkeetna Mountains, southcentral Alaska: Geology, v. 4, p. 49-52.

Jones, D. L., Silberling, N. J., and Hillhouse, John, 1977, Wrangellia-A displaced terrane in northwestern North America: Canadian Jour. Earth Sci., v. 14, p. 2565-2577.

Framework grain mineralogy and provenance of sandstones from the Arkose Ridge and Chickaloon Formations, Matanuska Valley

By Gary R. Winkler

Modal analyses of 20 thin sections from the Arkose Ridge Formation and eight from the Chickaloon Formation, courtesy of Arthur 
Grantz and George Plafker, indicate that sandstones from both formations are subquartzosethat is, their total of quartzose grains is less than 50 percent. In proportions of their other detrital constituents, however, sandstones from the two formations are completely dissimilar and plot in distinct fields in a Q-F-L ternary diagram (fig. 37). Modes of samples from the Arkose Ridge Formation plot within the feldspathic and lithofeldspathic fields of Dickinson (1970), whereas modes of samples from the Chickaloon Formation plot within the lithic or feldspatholithic fields. The most obvious dissimilarity is the scantiness of lithic detritus (averaging about 6 percent) in Arkose Ridge samples and the abundance of lithic detritus (about 52 percent) in Chickaloon samples. Also strikingly dissimilar is the relative abundance of biotite (averaging 8.3 percent) in Arkose Ridge samples and the paucity of biotite (1.0 percent) in Chickaloon samples.

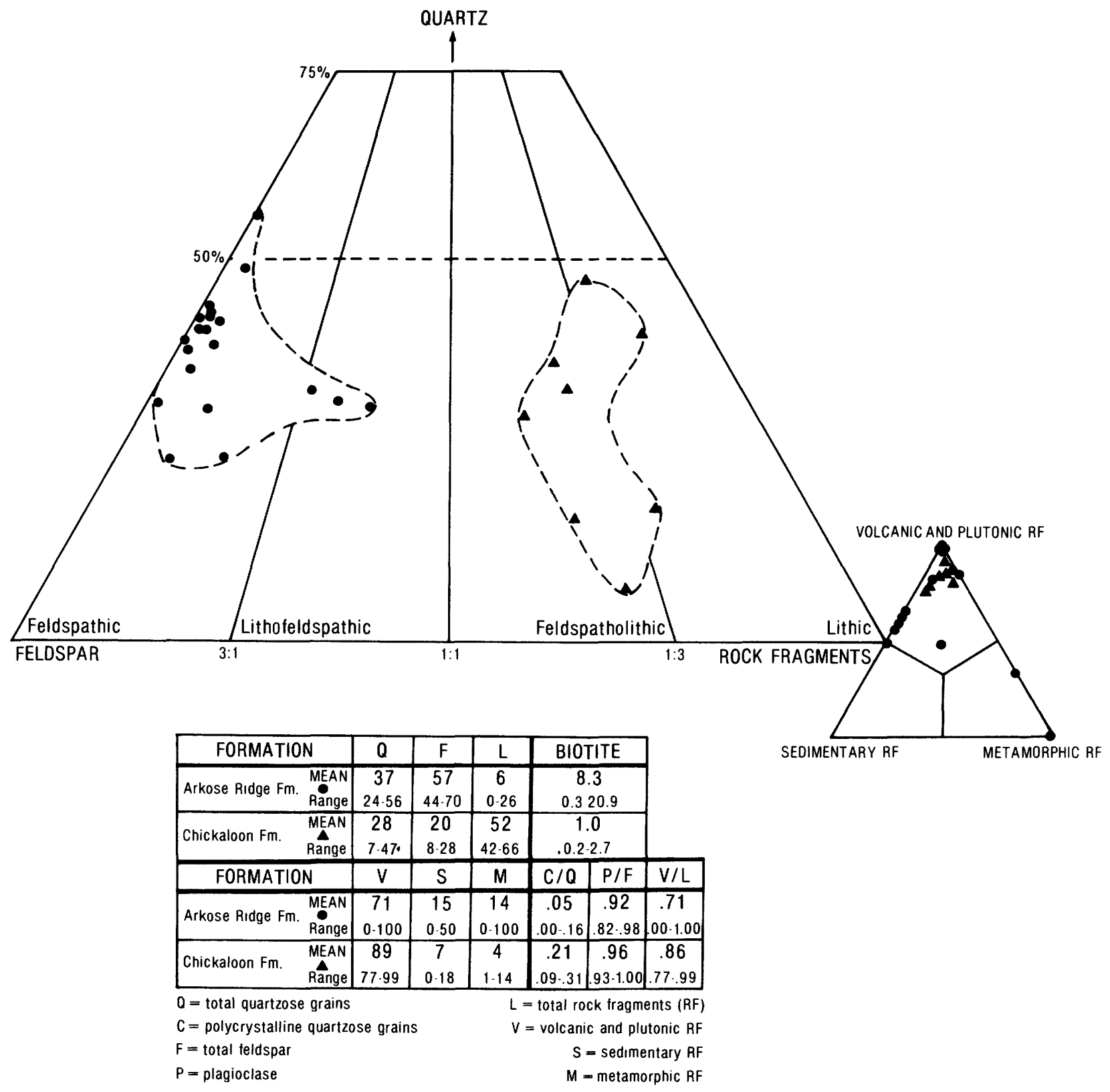

FIGURE 37.-Framework grain compositions of 28 point-counted sandstones from the Matanuska Valley; roughly following the classifications of Crook (1960) and Dickinson (1970). 
Subdivision of the ternary end-members, total quartzose grains (Q), total lithic grains $(\mathrm{L})$, and total feldspar grains (F), into components further enhances the distinctions between the Arkose Ridge and Chickaloon samples. Onetwentieth of the total quartzose grains in the Arkose Ridge Formation are polycrystalline (C), expressed as an average ratio (C/Q) of 0.05 , whereas about one-fifth of Chickaloon quartzose grains are polycrystalline $(C / Q=0.21)$. In addition, in the Chickaloon Formation, on the average, a much greater proportion of total lithic grains are altered intermediate to mafic volcanic grains (V), which may be expressed as $\mathrm{V} / \mathrm{L}$ ratio of 0.86; in the Arkose Ridge Formation on the average nearly one-third of total lithic grains are sedimentary (S), metamorphic (M), or plutonic $(\mathrm{V} / \mathrm{L}=0.72)$. No statistical significance can be attached to the slight difference in plagioclase feldspar (P) to total feldspar (F) ratios between the Arkose Ridge $(\mathrm{P} / \mathrm{F}=0.92)$ and Chickaloon (0.96) Formations, but myrmekitic and antiperthitic textures that are common in feldspar grains of Arkose Ridge samples have not been observed in feldspar grains of Chickaloon samples.

Heavy minerals are not abundant in samples from either the Arkose Ridge or Chickaloon Formations; their average modes are only 1.6 percent and 1.1 percent, respectively. In Arkose Ridge samples, epidote, sphene, and apatite predominate in the heavy-mineral suites, although hornblende or muscovite may be the most numerous heavy minerals in particular samples. Zircon is frequently present in trace amounts, and allanite, augite, garnet, and detrital chlorite are sporadically present. In Chickaloon samples, muscovite, epidote, garnet, and apatite commonly are present, and glauconite, hornblende, pumpellyite, and zircon have been noted in single samples. The only consistent difference between heavy-mineral suites from the two formations is the ubiquity of sphene in Arkose Ridge samples and its apparent absence from Chickaloon samples. Also, garnet frequently is present in Chickaloon samples but rarely is present in Arkose Ridge samples.

Clardy (1974) presented mineralogical data on 16 samples from the Chickaloon Formation and four from the Arkose Ridge Formation that compare favorably with these data. His Arkose Ridge sandstones have an average composition of
$\mathrm{Q}_{22} \mathrm{~F}_{69} \mathrm{~L}_{09} ;$ his Chickaloon sandstones have an average composition of $Q_{30} F_{22} L_{48}$. His reported average values for $C / Q$ are 0.06 and 0.18 for his Arkose Ridge and Chickaloon samples, respectively.

Sandstones of the Arkose Ridge Formation are derived largely from a plutonic provenance. Most diagnostic are the abundance of mica and feldspar (particularly myrmekitic and antiperthitic varieties) and the scantiness of lithic and polycrystalline quartzose detritus. The ubiquity of sphene and the trace occurrence of allanite among the heavy minerals also indicate derivation from a plutonic terrane.

On Government Peak, Arkose Ridge, and Eska Mountain, the formation rests unconformably on biotite and biotite-hornblende tonalite, quartz diorite, and associated metamorphic rocks of the Talkeetna batholith (Grantz and Wolfe, 1961). The age of these subjacent rocks recently has been demonstrated to be Middle and Late Jurassic (Csejtey and others, 1977). Pebbles from near the base of the formation are weakly foliated biotite and biotite-hornblende tonalite and quartz diorite, and it is plausible that the Arkose Ridge Formation sandstones also are largely derived locally from unroofing of the plutonic and metamorphic terrane.

Where the Arkose Ridge Formation is presumed to lap onto the schist of Willow Creek at the southwest end of the Talkeetna Mountains, local derivation also is indicated, for detritus and conglomerate includes pebbles of crenulated schist (Arthur Grantz, oral commun., 1976) and in sandstone includes numerous foliated lithic grains and composite amphibole-quartz-epidote metamorphic grains. This terrane is dated by potassium-argon methods on muscovite at approximately 60 m.y. (Csejtey and Smith, 1975). This age may record an uplift age of the Willow Creek terrane.

The predominantly volcanic provenance of the Chickaloon Formation is in complete contrast to that of the Arkose Ridge Formation. About half the detritus in eight Chickaloon samples is rock fragments, of which 89 percent is strongly to weakly altered volcanic lithic detritus. In addition, polycrystalline quartzose grains that probably represent silicified volcanic detritus are abundant. The provenance of Chickaloon Formation sandstones, however, is somewhat mixed. 
The presence of minor detrital carbonate grains, foliated lithic grains, and detrital garnet and pumpellyite indicate some derivation from uplifted sedimentary and metamorphic rocks. Nonetheless, the preponderant detritus in sandstones of the Chickaloon Formation is volcanic; inasmuch as the detritus is consistently altered, it may have been derived from an older volcanic unit-perhaps the adjacent Talkeetna Formation-not from incorporation of contemporaneous volcanic debris.

\section{REFERENCES CITED}

Clardy, B. I., 1974, Origin of the lower and middle Tertiary Wishbone and Tsadaka Formations, Matanuska Valley, Alaska: Fairbanks, Alaska Univ., M.S. thesis, 74 p.

Crook, K. A. W., 1960, Classification of arenites: Am. Jour Sci., v. 258, p. 419-428.

Csejtey, Béla, Jr., and Smith, J. G., 1975, Petrography, tentative age, and correlation of schist, Willow Creek, Talkeetna Mountains, southern Alaska, in Yount, M. E., ed., United States Geological Survey Alaska program, 1975: U.S. Geol. Survey Circ. 722, p. 48.

Csejtey, Béla, Jr., Nelson, W. H., Eberlein, G. D., Lanphere, M. A., and Smith, J. G., 1977, New data concerning age of the Arkose Ridge Formation, south-central Alaska, in Blean, K. M., ed., The United States Geological Survey in Alaska; accomplishments during 1976: U.S. Geol. Survey Circ. 751-B, p. B62-B64.

Dickinson, W. R., 1970, Interpreting detrital modes of graywacke and arkose: Jour. Sed. Petrology, v. 40, p. 695-707.

Grantz, Arthur, and Wolfe, J. A., 1961, Age of Arkose Ridge formation, south-central Alaska: Am. Assoc. Petroleum Geologists Bull., v. 45, p. 1762-1765.

Generalized physiography and geology of the Beluga coal field and vicinity, south-central Alaska By Henry R. Schmoll and Lynn A. Yehle

The Beluga coal field lies on the northwest flank of Cook Inlet basin, about $100 \mathrm{~km}$ west of Anchorage, and the Tertiary sedimentary rocks that underlie it contain abundant deposits of coal. There is good potential for coal mining in several parts of the area, some of which are indicated on figure 38. Exploration is currently proceeding and development is in the planning stages for some of these places.

Although lying generally within the Cook Inlet-Susitna lowland, the Beluga coal field comprises a relative upland that is drained mainly by the Chuitna and Beluga Rivers and that rises in elevation from about $100 \mathrm{~m}$ near Cook Inlet to about $900 \mathrm{~m}$ near Capps Glacier. The Tertiary rocks are overlain by Quaternary surficial deposits that range in thickness from several tens of meters in the southeast to less than a meter in the northwest. Lowlands flank the upland on the southwest and southeast; here bedrock is covered by thicker and probably finer grained Quaternary sedimentary deposits, partly of marine and estuarine origin. The upper Beluga River lies in a smaller, less well defined lowland that includes some Quaternary lacustrine deposits. The east edge of the Tordrillo Mountains borders the upland to the west.

Steep escarpments about 75 to $150 . \mathrm{m}$ high, where slopes of $\mathbf{4 5}$ percent or more are common, border the major rivers which are incised into the upland surface. Bedrock and surficial deposits are exposed intermittently in cliffs. Landslides and other colluvial deposits are common, and stability is generally poor, especially where the rivers are actively eroding. Similar steep escarpments face Cook Inlet.

Broad escarpments, 150 to $300 \mathrm{~m}$ high, commonly separate the lowlands from the upland. These escarpments probably were the sites of glacial erosion as well as subsequent deposition of lateral moraines. Thus, at present, these escarpments are quite irregular; slopes between 15 and 30 percent are most common. In places along the broad escarpments the morphology is suggestive of slope instability and may include sackung features. Major landslides include the Tertiary bedrock; they may have formed fairly soon after deglaciation as the combined result of oversteepening of the slopes by glacial erosion, followed by withdrawal of glacier ice and the support it provided; melting of permafrost and burning of coal beds may have been additional aids to sliding.

Bedrock in much of the area has been described by Barnes (1966) and is not further discussed here. Bedrock mapped in figure 38 is taken from Barnes (1966) with modifications from Detterman and others (1976) and Magoon, Adkison, and Egbert (1976). The major faults shown are well established to the northeast (Castle Mountain fault), southwest (Lake Clark fault), and south-southwest (Bruin Bay fault); they are represented in exposed Tertiary rocks in this area, but their mutual intersection remains conjectural (Hackett, 1977), and unequivocal evidence of Holocene faulting in this area is still lacking. 


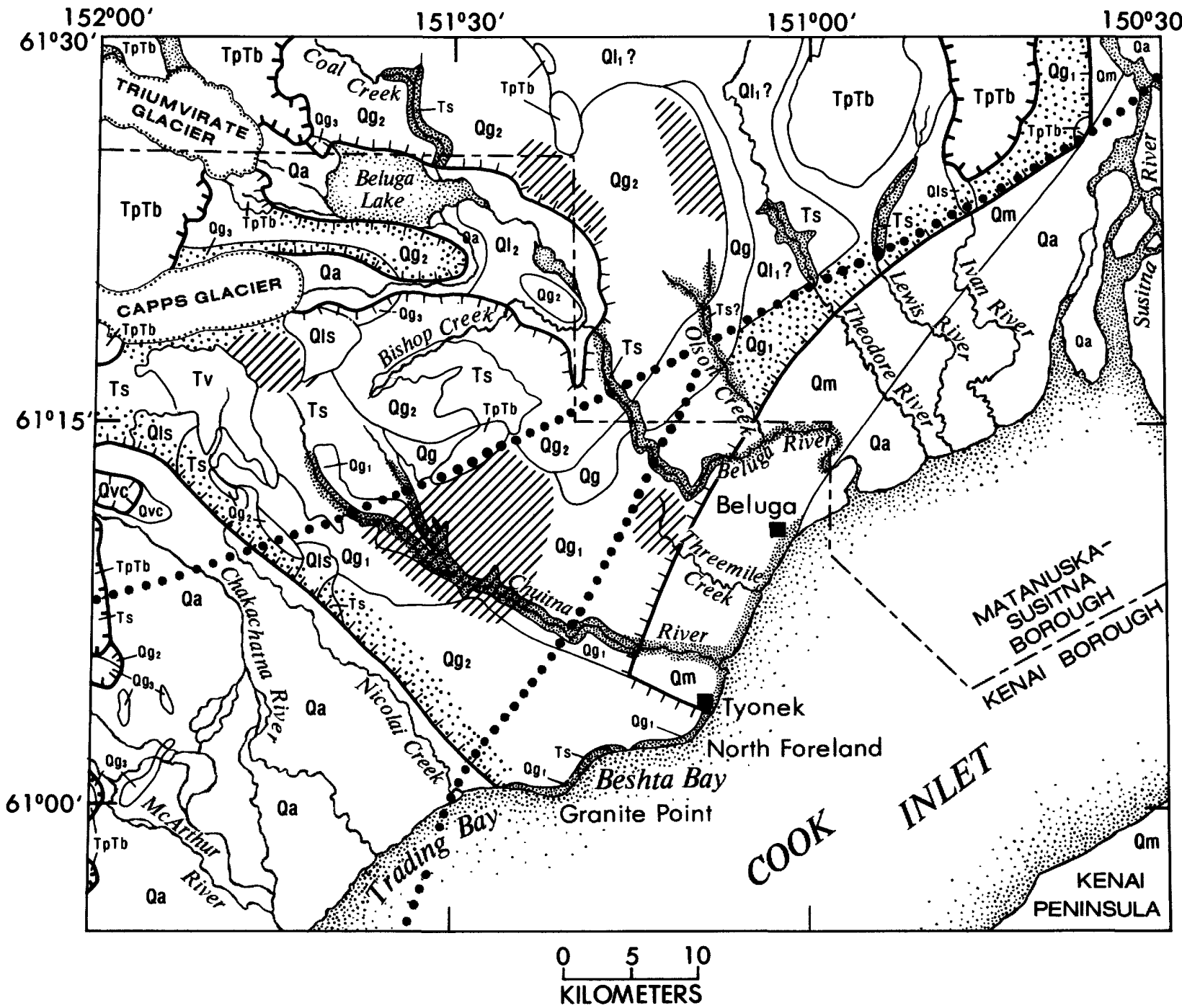

FIGURE 38.-Preliminary map showing generalized physiography and geology of the Beluga coal field and vicinity, southcentral Alaska. Explanation on next page.

Glacial deposits of Pleistocene age are shown in figure 38 as divided into an older and younger group, in places separated by a belt of undifferentiated glacial deposits that are intermediate in age but that appear morphologically more similar to those mapped as younger deposits. The younger glacial deposits occur in two main belts, each bordered by a fairly prominent terminal moraine. The more northerly belt represents a glacier from both the present Capps Galcier and Triumvirate Glacier valleys; the southerly belt represents the northern margin of a glacier from the Chakachatna and McArthur valleys.

The area of older glacial deposits is more varied than that of the younger deposits. In the upper Chuitna valley the till exposed in river bluffs appears to be substantially older than that in the younger moraines and is overlain locally by 


\section{EXPLANATION}

aa Alluvial, estuarine, and marine deposits (Holocene)

ag Glacial deposits. Chiefly lateral and end moraines (Holocene)

als Landslide deposits (Pleistocene and Holocene)

$a_{2}$ Younger lacustrine deposits (Pleistocene and Holocene)

avc Volcaniclastic deposits and volcanic rocks (Pleistocene and Holocene)

am Marine, estuarine, and alluvial deposits (Pleistocene)

$\mathrm{ag}_{2}$ Younger morainal deposits (Pleistocene)

$0 g_{3}$ Morainal deposits, undifferentiated

01, Older lacustrine deposits (Pleistocene) $\mathrm{ag}_{1}$ Older morainal deposits (Pleistocene)

Tv Volcanic rocks

Ts Sedimentary rocks. Chiefly sandstone, siltstone, coal, and conglomerate

TPTD Other bedrock. Chiefly igneous and metamorphic rocks

\section{$\bullet \bullet \bullet \bullet$ Fault Black where well established, shaded where inferred \\ $\perp$ Base of mountains \\ Base of uplands \\ Potential coal mining areas \\ Broad escarpments \\ Steep escarpments}

FIGURE 38.-Continued.

tephra beds not found on the younger drift. Between the Beluga River and Mount Susitna the lateral moraines may be younger, more nearly comparable in age to those in the belt of undifferentiated glacial deposits. To the southwest the area of older glacial deposits includes many channels cut by streams emanating from younger glaciers and this area likely includes much younger outwash and related deposits. These and similar deposits mapped as younger glacial deposits in the area to the south probably will prove good sources of construction materials.

Lacustrine deposits likewise occur in a younger and an older belt. The younger deposits, which include silt and clay as well as sand and gravel overlying and adjacent to the silt and clay, some in deltaic beds, probably represent an enlarged version of Beluga Lake that formed following withdrawal of the younger glacier. The older deposits are conjectural, based in part on Karlstrom (1964, pl. 1); they more likely represent deposits in a local lake, however, rather than the regional lake postulated by Karlstrom.

The belt mapped as older marine, estuarine, and alluvial deposits that extends from Tyonek to the Susitna River represents a stratigraphic sequence consisting of silt and clay overlain by sand and gravel. A similar sequence at Anchorage includes the Bootlegger Cove Clay, radiocarbon dated at about 14,000 years B.P. (Schmoll and others, 1972). It cannot yet be established whether the clay in the Tyonek-Susitna River area is the same age as the Bootlegger Cove Clay or older; a similar clay farther down Cook Inlet at Nikiski (Karlstrom, 1964) and West Foreland (Detterman and others, 1976) may be older than the Bootlegger Cove Clay. Its marine character, however, is suggested by the presence of marine foraminifers similar to those in the Bootlegger Cove Clay, found farther up the Susitna Valley (P. B. Smith, written commun., 1971) in clay that appears continuous with that mapped here.

Glacial deposits of Holocene age are mapped near Triumvirate and Capps Glaciers, and also near the McArthur River. Pending radiocarbon dates should provide more accurate placement of these deposits in time. The front of Triumvirate Glacier appears to have been fairly stable during the last 25 years, but Capps Glacier apparently retreated at least several hundred meters, leaving a series of very small transverse moraines as well as longitudinal "ribs" in the newly evacuated area.

The lowlands include alluvial, estuarine, and tidal deposits of Holocene age. Outwash, principally gravel and sand, dominates the areas in front of the glaciers, as well as most of the McArthur and Chakachatna valleys; in these valleys the alluvium may grade downstream to tidal 
deposits near Trading Bay. Present-day tidal and estuarine silt and fine sand near Cook Inlet, and similar but somewhat older deposits to the northwest and north, dominate the area between the Beluga and Susitna Rivers; some river alluvium, somewhat coarser grained, probably occurs along the Susitna River.

Tephra, probably from volcanoes both in the Tordrillo Mountains and to the southwest, overlies the mapped deposits in places, but it is generally not mappable even at larger scales. Dating of these deposits can aid in establishing a framework for estimating volcanic hazards as well as dating moraines and other deposits; several radiocarbon dates are pending.

\section{REFERENCES CITED}

Barnes, F. F., 1966, Geology and coal resources of the Beluga-Yentna region, Alaska: U.S. Geol. Survey Bull. 1202-C, 54 p.

Detterman, R. L., Hudson, Travis, Plafker, George, Tysdal, R. G., and Hoare, J. M., 1976, Reconnaissance geologic map along the Bruin Bay and Lake Clark faults in Kenai and Tyonek quadrangles, Alaska: U.S. Geol. Survey Open-File Report 76-477, 4 p.

Hackett, S. W., 1977, Gravity survey of Beluga basin and adjacent area, Cook Inlet region, south-central Alaska: Alaska Div. Geol. and Geophys. Surveys, Geol. Rept. 49, $26 \mathrm{p}$.

Karlstrom, T. N. V. K., 1964, Quaternary geology of the Kenai lowland and glacial history of the Cook Inlet region, Alaska: U.S. Geol. Survey Prof. Paper 443, 69 p.

Magoon, L. B., Adkinson, W. L., and Egbert, R. M., 1976, Map showing geology, wildcat wells, Tertiary plant fossil localities, $\mathrm{K}$-ar age dates, and petroleum operations, Cook Inlet area, Alaska: U.S. Geol. Survey Misc. Geol. Inv. Map I-1019, 3 sheets, scale 1:250,000.

Schmoll, H. R., Szabo, B. J., Rubin, Meyer, and Dobrovolny, Ernest, 1972, Radiometric dating of marine shells from the Bootlegger Cove Clay, Anchorage area, Alaska: Geol. Soc. America Bull., v. 83, no. 4, p. 1107-1113.

Analysis of remotely sensed data for use in evaluating the onshore impacts of offshore petroleum development at Kenai, Alaska

By Harry F. Lins, Jr.

Analysis of time-sequential aerial photographs in concert with field data indicates that remotely sensed data can be employed effectively in evaluating the magnitude and types of onshore impacts of offshore oil and natural gas development. These remotely sensed data are most accurately applied, however, to frontier regions such as Kenai.
Using the U.S.G.S. classification system (Anderson and others, 1976), land-use and landcover maps were compiled for the Kenai-Nikiski area for time periods coincidental with pre-petroleum development (1951), onshore petroleum development (1961), offshore petroleum development and associated onshore construction (1967), and offshore development decline and offshore production (1972). During the pre-petroleum period, Kenai was mainly a homesteading area with very little urban-type growth and no industry except for commercial fishing and associated canneries. On the basis of this frontier condition, it was assumed that land-use changes occurring during or immediately after petroleum exploration, development, and production would be almost entirely the result of such activities. Furthermore, it was assumed that most of all of these land-use changes would be within the level I category of urban or built-up land.

The maps in figure 39 depict the magnitude of change in the Kenai-Nikiski area resulting from both onshore and offshore oil and natural gas development. Using published data on petrochemical fields and their respective production rates (State of Alaska, 1973), it was determined that most of the land-use change resulted from the offshore industry. Figure 39 a depicts the extent of urban or built-up land in 1951, during the homesteading period prior to petroleum exploitation. The small amount of urban development was restricted to the village of Kenai. By 1961 (fig. 39b) oil had been discovered onshore at Swanson River, approximately $32 \mathrm{~km}$ northeast of Kenai. This resulted in the construction of a marine terminal at Nikiski for transporting the crude oil, along with some related commercial and service facilities along the strip between Kenai and Nikiski. Kenai had become a "first class city" (State of Alaska, 1974).

The impact of offshore oil development, initiated in 1964, is seen in figure 39c, which shows urban or built-up land in 1967. Strip development, in the form of petroleum support services, had increased between Kenai and Nikiski. Residential land expanded in both Kenai and northeast of Nikiski, along with expansion of the marine terminal facilities which included one refinery. By the time of the production phase in 1972 (fig. 39d), Kenai had grown dramatically, complete with used-car dealerships, fast-food establishments, and almost one church for each re- 

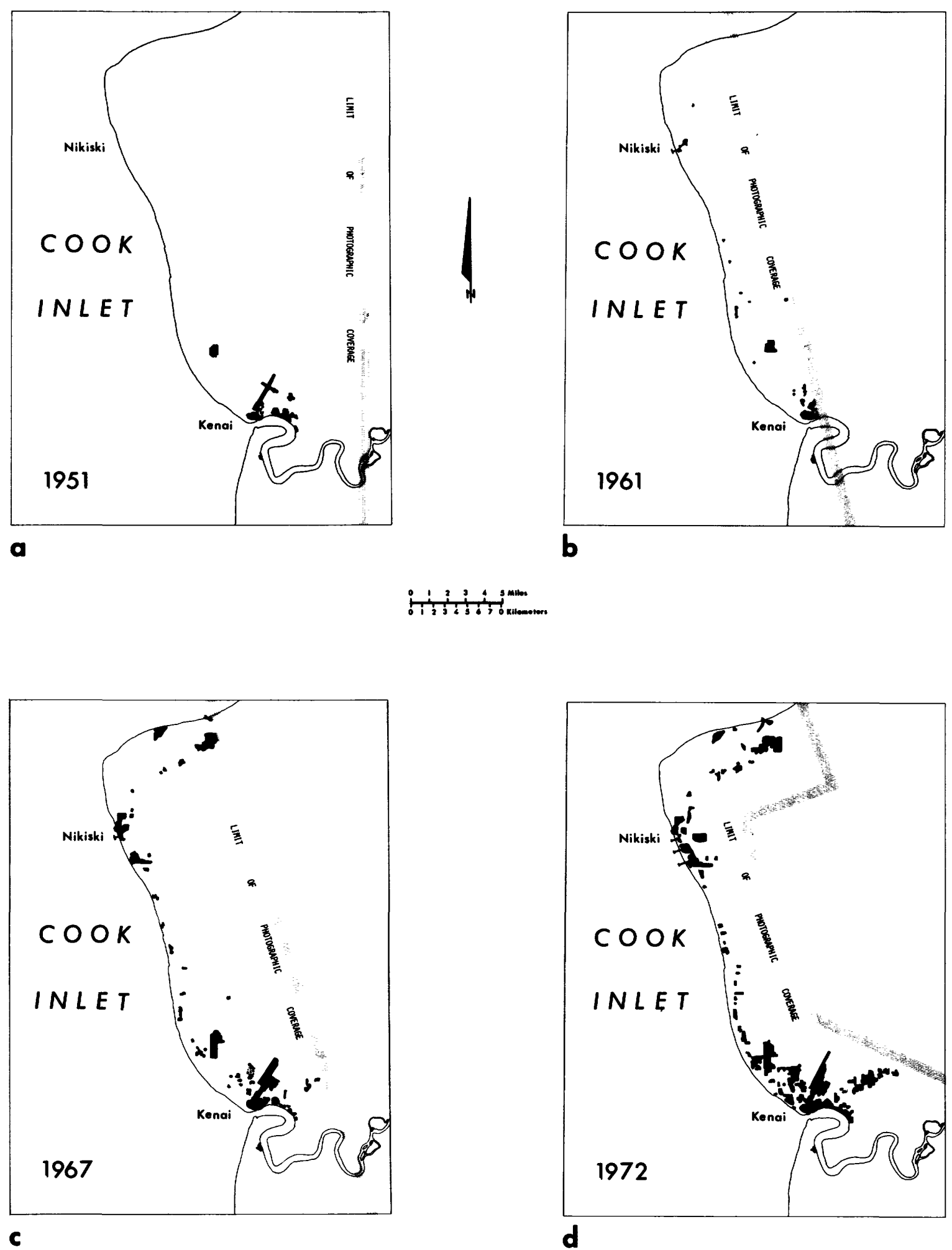

FigURE 39.-Urban and developing land, Kenai test site; 1951, 1961, 1967, and 1972, as interpreted from aerial photography. 
ligious denomination found in Alaska. The commercial strip along the coast was nearly continuous. The terminal at Nikiski had four refineries, and growth continued to the northeast. As previously mentioned, it was determined from published sources that nearly all changes appearing in figures $39 \mathrm{c}$ and $39 \mathrm{~d}$ were the result of offshore petroleum development.

Results indicate that remotely sensed data, with some limitations, can be used to analyze locations and types of land changes resulting from offshore petroleum development. Furthermore, this type of information lends itself well to mensuration of particular land-use categories, landuse changes, spatial patterns, and trends. Remotely sensed data, however, do not always contain the kind of information needed to identify the relations between land-use and land-cover types.

\section{REFERENCES CITED}

Anderson, J. R., Hardy, E. E., Roach, J. R., and Witmer, R. E., 1976, $A$ land use and land cover classification system for use with remote sensor data: U.S. Geol. Survey Prof. Paper 964, $28 \mathrm{p}$.

State of Alaska, 1973, Statistical report: Alaska Dept. Natural Resources, Div. Oil and Gas, Juneau, Alaska.

1974, Alaska regional profiles; south-central region: Juneau, Alaska, v. 1, 255 p.

Application of remotely sensed data for groundwater analysis near Denali, Alaska

By James K. Richard, Technicolor Graphic Services, Inc. ${ }^{2}$

Favorable areas for ground-water exploration near Denali, Alaska have been identified by the use of remotely sensed data. Manual interpretations were made part of a computer-enhanced Landsat false-color composite (image \#547019560, taken August 1,1976) at 1:250,000 scale and color infrared photographs at 1:30,000 scale. The interpretations were checked in the field and modified as necessary.

Four interpretive overlays were made indicating features important to the development of a targeting strategy and hydrogeologic model. The overlays present information on stream drainage, drainage basins, and landforms at two scales (1:250,000 and 1:30,000).

Analysis of drainage patterns was used to de-

${ }^{2}$ Prepared under U.S. Geological Survey Contract 14-08-0001-16439. lineate surface drainage basins and to provide information on deposit permeability. Poor integration of streams in nonmountainous areas indicates more permeable underlying materials in which recharge probably occurs. This relation is striking on the mountain flanks, where many streams disappear because of infiltration.

Identification of surface water divides was useful in defining probable ground-water basins and in mapping regional ground-water flow directions. The Susitna River drains the study area. Regional flow in the study area is toward the Susitna River, by way of 14 sub-basins. The stream drainage and drainage basin overlays define direction of runoff, and ground-water flow, areas of maximum storage, and the primary discharge zone-the Susitna River.

Areas of unconsolidated materials were subdivided on the basis of differences in drainage and vegetation patterns, apparent slopes, and landforms. On 1:250,000-scale Landsat imagery, major landforms were separated into four types: exposed bedrock, bedrock with a thin cover of overburden, terrace deposits, and alluvium. Further classification of the mountain flank areas was possible on 1:30,000-scale color infrared photography. Unconsolidated materials interpreted as terrace deposits on 1:250,000-scale Landsat imagery were separated into two classes: terrace levels and talus deposits. The large-scale photography shows that recharge areas occur where many streams disappear on the terraces.

A hydrogeologic model has been developed to explain recharge, discharge, and flow within the Susitna River valley ground-water system. The model is based on interpretations made from Landsat imagery that have been verified in the field and on 1:30,000-scale color infrared aerial photography. Areas of exposed bedrock and bedrock with thin overburden supply much of the runoff to the Susitna River valley drainage basin. Slopes are steep, locally nearing $50^{\circ}$, and the material generally has a low permeability. Most infiltration occurs on the upper terrace level where runoff from the mountains first flows over permeable, unconsolidated material. The large number of disappearing streams is evidence of rapid infiltration. Ground water is assumed to flow toward the Susitna River from infiltration areas. The Susitna River valley is, therefore, assumed to be the area of maximum storage.

The model can also be used to locate areas 
where ground-water development is both feasible and practical. Under most circumstances, ground-water supplies are most successfully obtained in or near major storage areas. In this area, however, the Susitna River flood plain is relatively inaccessible. Soils and vegetation are delicate and incapable of supporting continued use. Saturated ground is quickly made impassable by vehicular traffic during warmer seasons. The better drained, more stable ground of the upper two terrace levels is best for exploration for ground-water supplies. These areas are most likely to be developed, and the targeting strategy can be considered consistent with potential landuse demands.

Computer enhancement of Landsat digital data for mapping material-related geomorphic featurs near Denali, Alaska

By Cynthia A. Sheehan, Technicolor Graphic Services, Inc. ${ }^{3}$

A series of computer enhancement processes were performed on Landsat digital data to demonstrate techniques for mapping material-related geomorphic features in lowland areas near Denali, Alaska. On a standard Landsat false-color composite, the lowland areas appear almost homogeneously red, masking much of the geologic detail. Moreover, in the photographic reproduction process, tones are smoothed and the image loses sharpness. By using Landsat digital data, contrast can be adjusted to enhance features of interest and to produce a sharper, more easily interpreted image.

Striping on the image caused by unequal response of the Landsat multispectral scanner detectors can obscure linear features on the ground. The application of a histogram normalization function, commonly called destriping, removes this artificial pattern.

A destriped August 1, 1976 subscene of Landsat image 5470-19560 covering a 118,623 ha area of the Susitna River valley was analyzed using an interactive multispectral image analysis system. The four enhanced images produced were a linear contrast enhancement, a ratio, a linear contrast enhancement of the ratio, and an enhanced hybrid containing bands 5 and 7 and the band 5/band 6 ratio. Black-and-white transparencies of each band or individual ratio were recorded with a laser-beam recorder and used to generate

\footnotetext{
3 Prepared under U.S. Geological Survey Contract 14-08-0001-16439.
}

color composites. The resulting color images and an image that was contrast- and edge-enhanced by the EROS Digital Image Enhancement System (EDIES) were analyzed to determine the optimum image for investigating material-related geomorphic features.

The linear contrast enhancement best minimizes the "masking effect" of the vegetation in the lowland area. Contrast in bands 4 and 5 was increased to reveal the maximum amount of detail in the lowland area. On band 7, the enhancement was intended to reduce contrast within vegetation types in the valley and emphasize the tall shrub vegetation type along the lowlandmountain boundary. The resulting enhanced image has a twofold advantage over the original image:

1) The enhanced image shows more detail in the mottled lowland area and sharper landwater boundaries. The location of moraines, various terrace levels, and outwash deposits is based on patterns in the mottling and alinement of lakes.

2) The tall shrub vegetation emphasized is concentrated at the base of the mountain, especially on talus slopes, and its lower boundary approximately delineates the upper boundary of the Quaternary terrace deposits. This vegetation type also extends upstream into the mountains; therefore, drainage in the upland areas is also enhanced.

Three terrace levels can be mapped in the Denali area. The linear alinement of lakes along margins of the Susitna River valley delineates topographic breaks at the base and crest of the lowest terrace. The upper two terraces were mapped using tonal pattern alinement rather than lake locations. Field inspection of the lowland areas confirmed that tonal variations on the image correspond to variations in topography and vegetation on the ground.

In the highland area, drainage patterns were used for a general structural analysis. The rectangular drainage of the Valdez Creek tributaries has a pronounced northeast-southwest orientation. This area contains sedimentary and metasedimentary rocks striking northeast. To the north and south the drainage is more dendritic because it developed on more homogenous igneous and volcanic terranes.

The ratio composite and ratio composite with 
linear contrast enhancement of the Denali area are dark and contain very little detail in the lowland area. They were not useful for a study of this type. However, one of the enhanced ratios, band $5 /$ band 6 , did show additional detail in the terrace areas. It was combined with bands 5 and 7 to form a hybrid false-color composite. This composite is similar in appearance to the linear-contrast-enhanced image. The increased detail in the terraces was due to the increased relative brightness of vegetation in depressions and small valley slopes. Because there is more detail in the overall lowland area in band 4 than in ratio band $5 /$ band 6 , however, the hybrid false-color composite proved no better than the linear-contrastenhanced image.

For the EDIES false-color composite, the data were destriped and linear-contrast enhanced using a standard percentage of the histogram for truncation limits. In this image, changes in vegetation on band 7 were enhanced from the original image, further masking rather than enhancing geologic features.

An additional enhancement technique, edge enhancement, was used in creating the EDIES image. Edge enhancement is designed to enhance boundaries between features with similar spectral characteristics. In the highlands, the drainage and its orientation are emphasized. Because linear structural elements in the highland area are directly reflected in drainage development, edge enhancement is useful for mapping geologic structure. In lowland areas, the mottled tones of the outwash and terrace deposits have no particular pattern. With limited analysis it appears that edge enhancement may, in certain areas, homogenize the mottling rather than enhance it.

In the Denali area, the linear-contrast-enhanced image is best for mapping material-related geologic features in the lowlands. Although ratio images have proved useful in other study areas, the ratio and hybrid images do not provide additional information at the Denali site. The edge enhancement on the EDIES product emphasizes structurally related drainage patterns in the highland area, but does not appear advantageous in studying lowland features. This type of enhancement would be more helpful if it were used in conjunction with the contrast enhancement that emphasizes lowland features.
Classification of vegetation in the Denali, Alaska area with digital Landsat data

By Wayne G. Rohde, Wayne A. Miller, and Charles A. Nelson, Technicolor Graphic Services, Inc.4

Landsats -1 and -2 provide resource scientists with an opportunity to acquire multispectral data repetitively over large regions. Several investigators have reported the application of Landsat data for mapping wildland vegetation (Bentley and others, 1976; DeGloria and others, 1975; Krebs and Hoffer, 1976; La Perriere, 1976). Successful application of these data to resource mapping requires implementation of interpretive methods that allow quick, consistent, accurate, and economical extraction of information. The objective of this project was to demonstrate the application of Landsat digital data for classification of wildland vegetation and to assess the accuracy of this application.

Landsat-1 scene 5470-19560, taken on August 1,1976 was selected for analysis as it provides recent, cloud-free coverage of the entire 118,623 -ha study area near Denali. Bureau of Land Management resource aerial photographs taken on August 24, 1976 were available for strips along the Denali highway. These photographs provide coverage of about 30 percent of the study area and were used to develop training statistics, associate cover types with computer classes, and verify the accuracy of the classification. Aerial photographs taken in July 1977 at an approximate scale of $1: 31,000$ were also used to verify accuracy.

A land-cover classification scheme was defined on the basis of a framework being developed for the Denali area. Nine cover types were defined as follows:

1. Clear water-inland lakes and streams with low sediment loads;

2. Sediment-laden water-streams and lakes with high sediment loads, for example, $\mathrm{Su}$ sitna River;

3. Barren-areas containing bare rock and soils with less than 25 percent vegetation cover, for example, roads, roadcuts, borrow pits, talus slopes, shoreline of lakes and rivers;

4. Tall shrub-shrub communities composed of alder (Alnus cripsa) and(or) willow (Salix sp.) in thickets ranging from 2.5 to $4.5 \mathrm{~m}$ high with crown densities of 25 percent or greater;

\footnotetext{
' Prepared under U.S. Geological Survey Contract 14-08-0001-16439.
} 
5. Low shrub-shrub communities composed of willow (Salix sp.) and(or) dwarf birch (Betula nana $\times$ B. glandulosa) with heights ranging from decumbent forms to as large as $2.5 \mathrm{~m}$ and having a crown density of 25 percent or greater;

6. Tundra-contains low, matlike plants or cushion plants, for example, sedges, mosses, lichens, blueberries, bog cranberries, and labrador tea. Small stands of low shrubs, less than 25 percent crown density, or trees in protected hollows may be found in this cover type;

7. Open conifer and low shrub-stands of timber with a crown density of 25 to 75 percent and an understory composed mainly of dwarf birch and willow less than $2.5 \mathrm{~m}$ high;

8. Open conifer and tall shrub-stands of timber with a crown density of 25 to 75 percent and an understory of alder and(or) willow, more than $2.5 \mathrm{~m}$ high; and

9. Dense conifer-stands of timber with a crown density of 75 to 100 percent and no visible understory.

Training statistics were derived using an unsupervised approach. A 10-percent sample of the pixels was processed with a spectral clustering algorithm. The algorithm identified 56 spectral classes in the sampled data. A mean brightness value and variance for each spectral band and a covariance matrix were calculated for each computer spectral class. These statistics were used in a maximum likelihood algorithm to classify each picture element into one of the 56 computer classes. Color infrared photography and field data collected in July 1976 were used to assign each computer class to one of the nine land-cover classes in the classification scheme.

Evaluation of the classification results indicated that water was mistakenly classified with barren land on steep north-facing slopes. An image stratification procedure was used interactively to outline mountainous barren areas. Picture elements within the barren areas, originally classified as water, were reclassified into the barren land class. After classification, a series of ground control points was selected to develop a mapping transformation for registering the classification results to U.S. Geological Survey 1:63,360-scale topographic maps. Colored map overlays for parts of four map sheets $(1: 63,360$ scale) were plotted on a flat-bed plotter.
A clustered-stratified random sampling procedure was used to estimate the accuracy of the land cover types displayed on the map overlays. On the basis of the area classified into each cover type, it was estimated that 2,050 plots, each 0.45 ha, would have to be sampled to estimate the classification accuracy of each cover type with a confidence interval of \pm 5 percent at the 0.95 probability level.

Using sampling for proportion statistics, the overall classification accuracy was estimated to be $84.5 \pm 4.2$ percent at the 0.95 probability level. Classification accuracy was calculated for each of the nine land cover types as follows: 1 ) clear water, 100 percent; 2) sediment-laden water, $99.1 \pm 0.6$ percent; 3 ) barren, $99.4 \pm 0.3$ percent; 4) tall shrub, 100 percent; 5) low shrub, 84.3 \pm 4.4 percent; 6) tundra, $89.8 \pm 3.9$ percent; 7) open conifer/low shrub, $85.2 \pm 2.7$ percent; 8 ) open conifer/tall shrub, $58.8 \pm 5.1$ percent; and 9) dense conifer, $52.3 \pm 6.2$ percent. On the basis of the cost of purchasing Landsat data and aerial photographs from the EROS Data Center, as well as computer time and man-hours required for analysis and accuracy verification, the cost for mapping wildland vegetation over 118,000 ha was estimated to be $\$ 0.039 / \mathrm{ha}$.

\section{REFERENCES CITED}

Bentley, R. G., Jr., Salmon-Drexler, B. C., Bonner, W. J., and Vincent, R. K., 1976, A Landsat study of ephemeral and perennial rangeland vegetation and soil: Bur. Land Management, Denver, Colorado, Final Report Type III, March 1975-December 1976, 234 p.

DeGloria, S. D., Daus, S. J., Tosta, N., and Bonner, K., 1975, Utilization of high-altitude photography and Landsat-1 data for change detection and sensitive area analysis, in International symposium on remote sensing of environment, Michigan, 10th, 1975, Proceedings: Ann Arbor, Michigan Environmental Research Inst., v. 1, p. 359368.

Krebs, P. V., and Hoffer, R. M., 1976, Multiple resource evaluation of Region 2 U.S. Forest Service lands utilizing Landsat MSS data: NASA Goddard Space Flight Center, Greenbelt, Md., Final Report Type III, July 1976, $298 \mathrm{p}$.

La Perriere, A. J. L., III, 1976, Use of Landsat imagery for wildlife habitat mapping in northeast and east-central Alaska: Alaska Univ., Fairbanks, Final Report, December 1976, NAS 5-20195, 39 p.

\section{Water resources studies in the Anchorage area} By Chester Zenone

Anderson (1977) completed a report on artificial recharge experiments conducted on the Ship 
Creek alluvial fan from 1972 to 1975. Dearborn (1977) reported that geologic and hydrologic data collected during drilling of a 450 -foot test well at the South Fork Eagle River alluvial fan indicated that there were no aquifers present that could support large-yield production wells.

A digital model for steady-state (nonpumping) conditions in the confined ground-water system at Anchorage was developed; work began on a transient-state (pumping) model in November. The model will be used as a guide to select hydraulically favorable sites for future public-supply wells and to predict the effects of largevolume pumping on regional water levels.

An updated inventory of ground-water data in the Eagle River-Chugiak area has been completed and preparation of ground-water interpretive maps was underway in November 1977.

\section{REFERENCES CITED}

Anderson, G. S., 1977, Artificial recharge experiments on the Ship Creek alluvial fan, Anchorage, Alaska: U.S. Geol. Survey Water Resources Inv. WRI-77-38, 39 p.

Dearborn, L. L., 1977, Ground-water investigation at the alluvial fan of the South Fork Eagle River, Anchorage, Alaska-Results of test drilling, 1976: U.S. Geol. Survey Open-File Report 77-439, 9 p.

\section{SOUTHEASTERN ALASKA}

New geological map of Ketchikan and Prince Rupert quadrangles, southeastern Alaska By H. C. Berg, R. L. Elliott, J. G. Smith, and R. D. Koch

A major goal of the Ketchikan project (which also includes the Prince Rupert quadrangle to the south) was reached in September 1977 with the completion of field studies of geology, geochemistry, geophysics, and mineral resources. A 1:250,000-scale reconnaissance geologic map of the quadrangles was published in January 1978 (Berg and others, 1978), and additional maps and reports describing the geochemistry, geophysics, satellite imagery interpretations, and mineral resources are scheduled for release by June 1978. For administrative reasons, the Ketchikan project was incorporated into the Alaska Mineral Resource Assessment Program (AMRAP) in 1975.

The new geologic map, generalized for this report in figure 40, includes three major geologic terranes. The east half of the map area is under- lain mainly by the Coast Range batholithic complex, a heterogeneous group of plutonic rocks and amphibolite-facies, metamorphosed, bedded rocks. The plutons range in emplacement age from Eocene to Miocene, in structure from gneissic to massive, and in composition from gabbro to granite, with grandiorite predominant. The metamorphic age both of plutonic and bedded rocks is Eocene. Structural trends, isograds, and lithologic units strike north to north-northwest. The northeasternmost part of the terrane is underlain by relatively less metamorphosed Triassic and Jurassic volcaniclastic and plutonic rocks. Mineral occurrences consist of porphyry molybdenum deposits in Miocene granite plutons, and sulfide vein and disseminated deposits in the metamorphic rocks that have been prospected for gold, silver, copper, lead, and zinc. Figure $\mathbf{4 0}$ is duplicated for convenience as figure 48 at the end of the report.

The central third of the map area is underlain by greenschist- to amphibolite-facies, metamorphosed sedimentary and volcanic rocks and by variously metamorphosed plutonic rocks ranging in composition from gabbro to quartz monzonite and in emplacement age from Cretaceous to Miocene. Regional metamorphic grade increases northeastward. Potassium-argon studies show Cretaceous metamorphic ages. Premetamorphic ages of the bedded rocks probably are late Paleozoic to late Mesozoic, with tectonic inliers of rocks possibly as old as Precambrian. Structural trends, isograds, and lithologic units strike northwest to west. Mineral occurrences include traces of molybdenite in some plutons, and sulfide vein and disseminated deposits in the metamorphic and plutonic rocks that have been prospected for antimony, gold, silver, lead, and zinc.

The remaining sixth of the map area lies southwest of the central terrane and contains the most varied lithology and most complete suite of stratified rocks in the Ketchikan and Prince Rupert quadrangles. It also includes the least metamorphosed pre-Tertiary rocks in the map area. The bedded rocks range in age from Silurian or older to Late Jurassic, and the plutonic rocks from Silurian or older to Cretaceous. Especially distinctive units include a Silurian or older stock of leucocratic trondhjemite, middle(?) Paleozoic rhyolite, and a Jurassic or Cretaceous zoned ultramafic complex that contains spectacular 
zones of rhythmically layered dunite and peridotite. Mineral occurrences include copper-bearing barite veins in the Paleozoic rhyolite, veins carrying gold, silver, and other metals in Upper Jurassic andesitic metatuff, and stratiform titaniferous magnetite deposits in the zoned ultramafic rocks.

Selected highlights of the Ketchikan-Prince Rupert map area include:

(1) The boundary between the central and eastern terranes is an abrupt structural discordance that may be the metamorphosed trace of a major late Mesozoic tectonic suture;

(2) The central terrane contains a swarm of Cretaceous garnet-bearing feldspar (plagioclase) porphyry stocks and smaller plutons that intrude variously metamorphosed pelitic and andesitic rocks. The swarm of plutons, which has been traced for at least $80 \mathrm{~km}$ northwest of the map area (Berg and others, 1976), terminates abruptly at the boundary of the eastern terrane;

(3) The central terrane contains northeastdipping to nearly flat thrust faults and fault zones that probably were regionally metamorphosed in Cretaceous time. The thrusts are roughly parallel to the axial surfaces of semirecumbent isoclinal folds overturned to the southwest; and

(4) A potentially economic porphyry molybdenum deposit occurs in a Miocene granite porphyry stock in the eastern terrane. Molybdenite also occurs in the eastern terrane in Miocene quartz porphyry dikes, in the Triassic and Jurassic rocks at the northeastern corner of the map area, and in at least one of the Cretaceous feldspar porphyry stocks in the central terrane.

\section{REFERENCES CITED}

Berg, H. C., Elliott, R. L., Koch, R. D., Cartin, R. B., and Wahl, F. A., 1976, Preliminary geologic map of the Craig D-1 and parts of the Craig C-1 and D-2 quadrangles, Alaska: U.S. Geol. Survey Open-File Report 76-430, 1 sheet, scale $1: 63,360$.

Berg, H. C., Elliott, R. L., Smith, J. G., and Koch, R. D., 1978, Geologic map of the Ketchikan and Prince Rupert quadrangles, Alaska: U.S. Geol. Survey Open-File Report 78-73-A, 1 sheet, scale 1:250,000.

Chemistry of Quartz Hill intrusive rocks, Ketchikan quadrangle

By Travis Hudson, Raymond L. Elliott, and James G. Smith

Major- and trace-element analyses of intrusive rocks associated with the Quartz Hill (Wilson Arm area) molybdenite deposit have been completed. The intrusive rocks form two composite hypabyssal stocks separated at the surface by a narrow septum of gneiss (Elliott and others, 1976; Hudson and others, 1977). The plutons contain several textural facies ranging from fineto medium-grained seriate biotite granite to felsic porphyry with very fine-grained to aplitic groundmasses. Sixteen samples representative of the textural facies were analyzed for trace elements by semiquantitative spectrographic methods.

A uniform felsic composition characterizes the major-element analyses; $\mathrm{SiO}_{2}$ ranges from 74.1 to 77.5 percent, $\mathrm{CaO}$ from 0.2 to 1.0 percent, $\mathrm{K}_{2} \mathrm{O}$ from 4.2 to 4.8 percent, and $\mathrm{Na}_{2} \mathrm{O}$ from 3.6 to 4.4 percent. The uniformity of composition is illustrated by the plot of normative $\mathrm{Q}-\mathrm{Or}-\mathrm{Ab}+\mathrm{An}$ ratios (fig. 41). The differentiation index for these (the sum of normative $Q+O r+A b$ ) is the compositional parameter that shows the most variation, ranging from 91.3 to 97.3 .

The trace-element composition of the samples is rather bland and shows no distinct enrichment in any of the analyzed elements. Many elements are present in amounts below their detection limits (for example, silver, arsenic, boron, bismuth, antimony, tin, tungsten, zinc), and most others are present in low to average amounts if compared to the average for low-calcium granites compiled by Turekian and Wedepohl (1961). Some elements present in low to average amounts are gallium, 7-18 ppm; lanthanum, $<$ 10-30 ppm; manganese, 220-540 ppm; lead, 17-34 ppm; scandium, 1.1-4.2 ppm; vanadium, 3.5-12 ppm; ytterbium, 0.5-5.9 ppm; and zirconium, 22-92 ppm. Barium (40-930 ppm) and strontium $(90-490 \mathrm{ppm})$ show the widest ranges of abundance. Beryllium (1.5-8.5 ppm) and niobium (11-83 ppm), on the average (4 and 25 ppm, respectively), may be slightly enriched relative to many other felsic rocks (Turekian and Wedepohl, 1961). Molybdenum is below detection limits (2.2 ppm) in all but two samples; these two samples contain 8 and $64 \mathrm{ppm}$ molybdenum, respectively. There is no obvious correlation of other trace elements with these two greater molybdenum values.

In summary, the intrusive rocks associated 


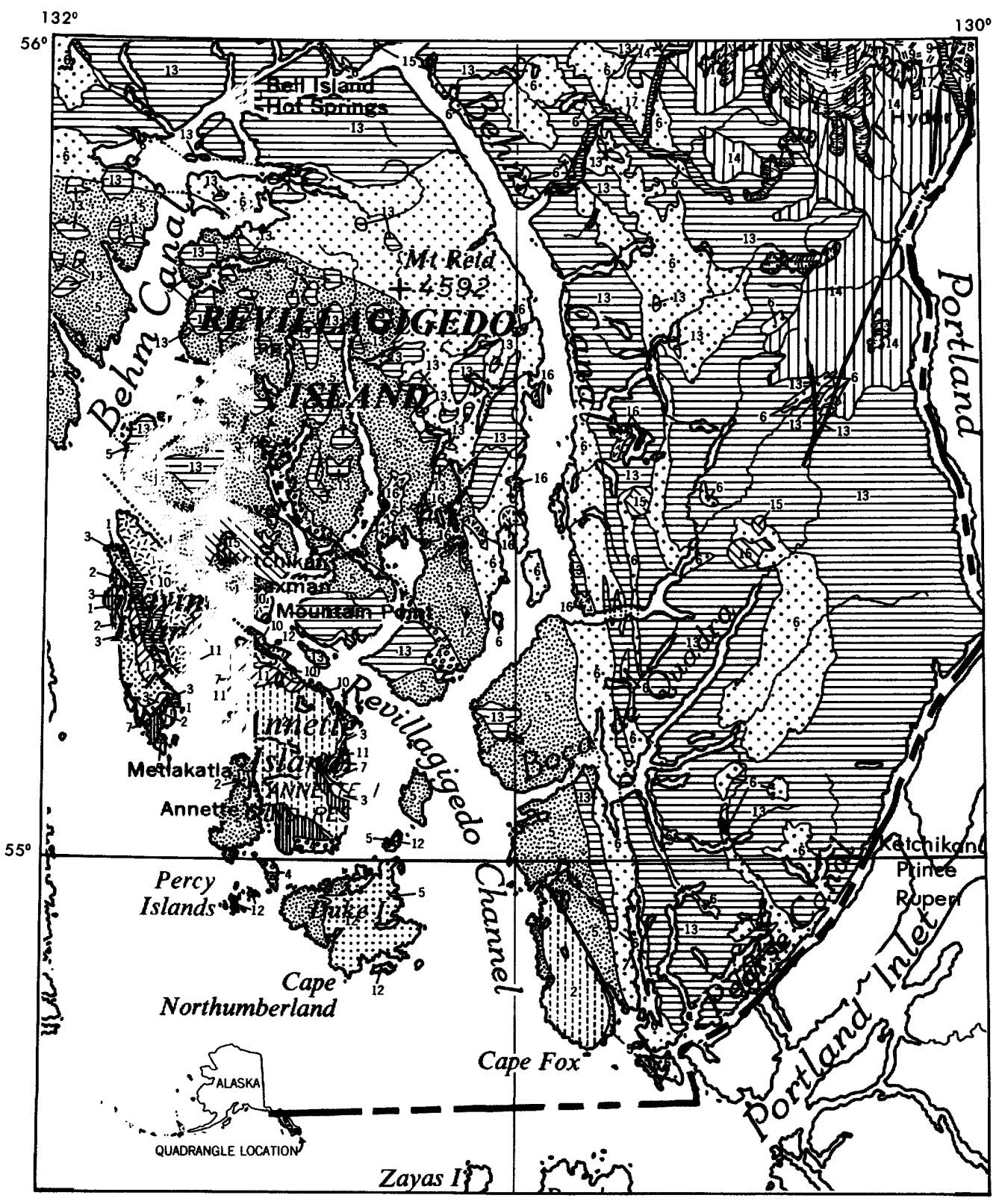

FIGURE 40.-Generalized geologic map of Ketchikan and Prince Rupert quadrangles, southeastern Alaska. Scale 1:1,000,000 or 1 inch equals approximately $26 \mathrm{~km}$. Base map from National Atlas of the United States, U.S. Geological Survey, 1970.

with the Quartz Hill molybdenite deposit are distinctly salic and uniform in the major-element composition. This composition suggests that the original magma represented either an initial melt formed at depth or a highly differentiated residual magma that was cleanly separated from its parent materials. The trace-element composition is distinctly bland and, in most samples, not enriched in any of the trace elements that were determined. This lack of enrichment could be interpreted as evidence against a differentiation origin from the magma. Additional chemical and isotopic studies are underway to help clarify the origin of the intrusive rocks and better understand the genesis of the associated molybdenum deposits. 


\section{REFERENCES CITED}

\section{CORRELATION OF MAP UNITS}

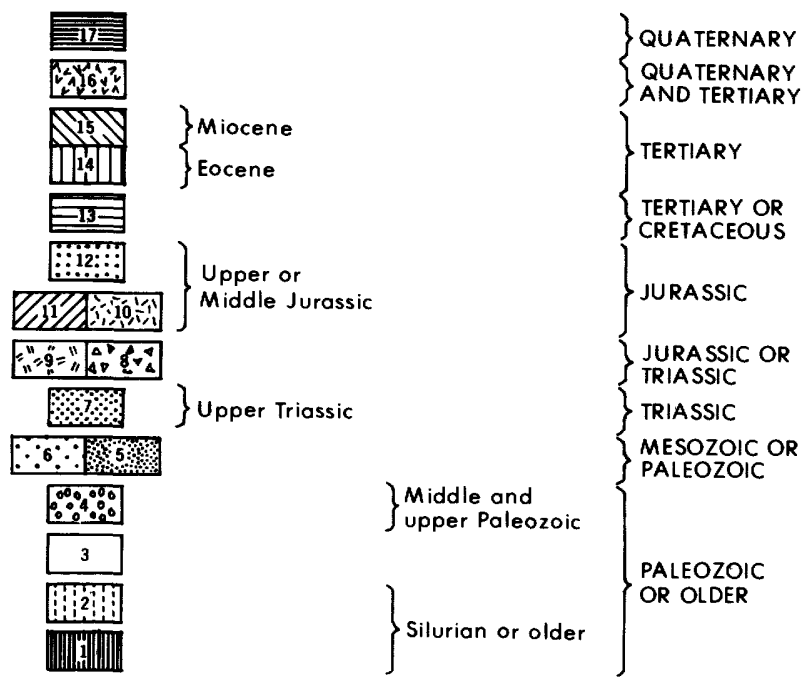

DESCRIPTION OF MAP UNITS

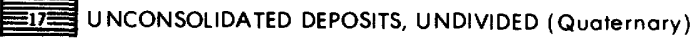

政W

DI5 PLUTONIC ROCKS, UNDIVIDED (Miocene)

П14. II PLUTONIC ROCKS, UNDIVIDED (Eocene)

13. PLUTONIC ROCKS, UNDIVIDED (Tertiary or Cretaceous) GRAVINA ISLAND FORMATION AND UNNAMED CORRELATIVE ROCKS (Upper or Middle Jurassic)

:12:: Ultramafic and other plutonic rocks

Vii7] Metasedimentary rocks

Metavolcanic rocks

TEXAS CREEK GRANODIORITE (Jurassic or Triassic)

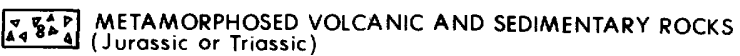
\% METAMORPHOSED SEDIMENTARY AND VOLCANIC ROCKS

$\because 6 \because$ PARAGNEISS AND AMPHIBOLITE (Mesozoic or Paleozoic)

5 METAMORPHIC ROCKS, UNDIVIDED (Mesozoic or PaleozoIC)

$\because 0 \%$ METAMORPHOSED SEDIMENTARY AND MINOR

$0 \% 4: 0$ VOLANIC ROCKS (Middle and upper Paleozoic)

3 FELSIC META VOLCANIC ROCKS (PaleozoIC or older)

: $1:$ PLUTONIC ROCKS, CHIEFLY TRONDHJEMITE (Silurian or older) |W||l||l||| METAMORPHOSED SEDIMENTARY AND VOLCANIC ROCKS

SYMBOLS

Contact. Approximately located; dotted where concealed

High-angle fault. Dashed where inferred;

dotted where concealed

Thrust fault. Dashed where concealed. Sawteeth on upper plate

FIGURE 40.-Continued.
Elliott, R. L., Smith, J. G., and Hudson, Travis, 1976, Upper Tertiary high-level plutons of the Smeaton Bay area, southeastern Alaska: U.S. Geol. Survey Open-File Report 76-507, $15 \mathrm{p}$.

Hudson, Travis, Elliott, R. L., and Smith, J. G., 1977, Investigations of the Wilson Arm molybdenite deposit, in Blean, K. M., ed., The United States Geological Survey in Alaska; accomplishments during 1976: U.S. Geol. Survey Circ. 751-B. p. B74.

Turekian, K. K., and Wedepohl, K. H., 1961, Distribution of the elements in some units of the earth's crust: Geol. Soc. America Bull., v. 72, p. 75-192.

Minor-metal content of Cretaceous greenstone near Juneau, Alaska

By Arthur B. Ford and David A. Brew

Greenstone and other metavolcanic rocks of the Douglas Island Volcanics of Lathram, Pomeroy, Berg, and Loney (1965) are widespread in the lower grade western part of a Barrovian regional metamorphic belt near Juneau (Ford and Brew, 1977a). The probable original rocks were locally pillow-bearing submarine basalt flows, tuff, and agglomerate, in places mixed with volcanic-derived graywacke and shale containing a sparse Cretaceous marine fauna (Ford and Brew, 1977b). In the Juneau area the volcanic terrane makes up Douglas Island, the east side of Lynn Canal south of Berners Bay, and Glass Peninsula on eastern Admiralty Island. Metamorphism was mainly in the prehnite-pumpellyite metagraywacke facies, increasing eastward to the lower greenschist facies on eastern Douglas Island.

The metavolcanic terrane in the Juneau area has been proposed by Berg, Jones, and Richter (1972) to be part of a late Mesozoic basinal andesitic island-arc system, named the Gravina-Nutzotin belt, that extended from southern southeast Alaska, near Ketchikan, to the eastern Alaska Range. In an analysis of the tectonic history of this belt, Connelly (1976, p. 147) assumes the composition of the Douglas Island to be andesitic. It is now known, however, that the greenstones on and near Douglas Island have only a limited range of olivine tholeiitic compositions (Ford and Brew, 1977b), and correlative greenstone near Berners Bay is alkali basaltic (Irvine, 1973), which raises considerable uncertainty about including this region in the proposed andesitic island-arc belt. Although volcanism may 


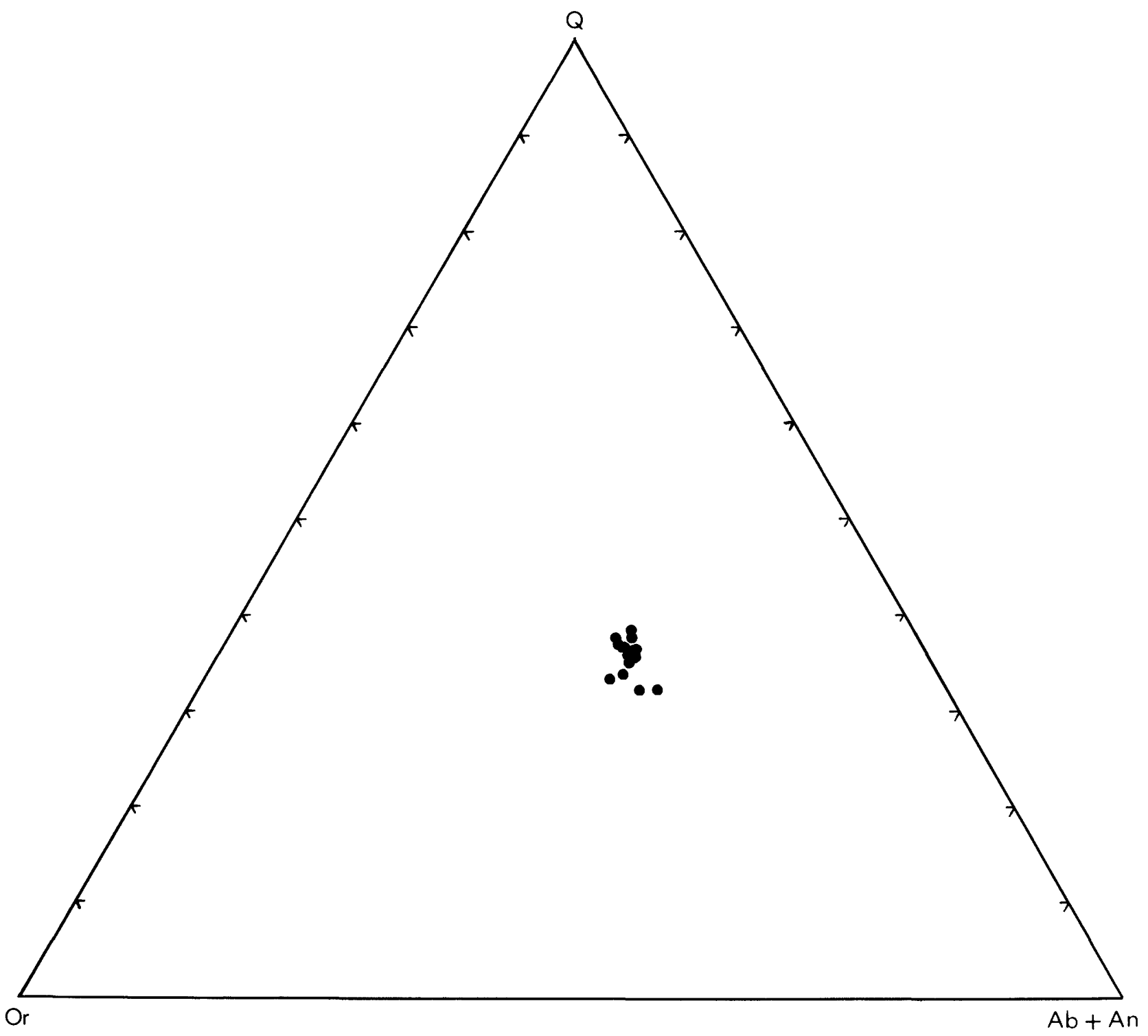

FigURE 41.-Plot of normative Q-Or-Ab+An ratios for Quartz Hill intrusive rocks, Ketchikan quadrangle.

have been approximately coeval in one or more basins along the Gravina-Nutzotin trend in interior southeast Alaska, it may have been associated with different tectonic regimes in different sectors of the belt.

Few published analytical data on the rocks in the Juneau area are available for comparing geochemical and petrologic characteristics with other parts of the proposed andesitic-arc belt. As part of our investigation of the Juneau 1:250,000scale quadrangle (Brew and Ford, 1974; Ford and Brew, 1977a), we therefore have undertaken a study of the chemistry of this terrane in an attempt to (1) determine as closely as possible the petrologic character of the original volcanic rocks, which cannot be identified mineralogically owing to extensive metamorphic alteration; (2) understand the tectonic setting of this volcanism by comparisons with well-known volcanic regions elsewhere; and (3) establish the nature of regional variation in the proposed Gravina-Nutzotin volcanic belt, which will contribute to a better understanding of the tectonic history of this part of southeast Alaska. The study, additionally, provides baseline data for investigation of the mineral resources of the Juneau area and for use in correlating poorly fossiliferous greenstone sequences of the region. (Near Juneau, pil- 
low-bearing greenstone and greenschist in places contain late Paleozoic or Triassic fossils but are otherwise difficult to distinguish from the upper Mesozoic volcanic rocks.)

Quantitative analyses for selected minor netals are shown in table 4 for 28 samples previously analyzed for major elements (Ford and Brew, 1977b). Cobalt, chromium, copper, nickel, scandium, and vanadium were determined by spectrographic analysis; and the platinum-group metals palladium, platinum, and rhodium were determined by the same combined fire-assay and spectrographic method used in the studies on correlative rocks reported by Page, Berg, and Haffty (1977).

Palladium is the only platinum-group metal found to be almost consistently present above its limit of determinabilty, which is 4 parts per billion (ppb). It is detectable in all 28 samples and its amount determinable in 27 samples. Platinum, with a limit of determinability of $10 \mathrm{ppb}$, is detectable in 19 samples (69 percent of the total) and determinable in only 5 samples (17 percent of the total). Rhodium, with a limit of determinabililty of $5 \mathrm{ppb}$, was not detected in any samples. Contents of other minor metals in table 5 are within detection limits for all samples.

No published data from other parts of the Gravina-Nutzotin belt are available for comparison with our analytical results, except for the platinum-group metals in the southern part of the belt near Ketchikan. For that area, Page, Berg, and Haffty (1977) report average contents of palladium and platinum to be respectively $11.5 \mathrm{ppb}$ and $15.7 \mathrm{ppb}$ and the average ratios Pt:Pd and $\mathrm{Pt}:(\mathrm{Pt}+\mathrm{Pd})$ to be respectively 1.37 and 0.578 . Rhodium is below detectability in all $\mathbf{4 0}$ of their

TABLE 4.-Average content of minor metals, in parts per million, of 28 metavolcanic rock samples from the Juneau area, compared with two average basalts

[Palladium determinations by Joseph Haffty and A. W. Haubert; others by R. E. Mays, Average basalt and olivine tholeiite compositions from Prinz (1967); tr.., trace]

\begin{tabular}{|c|c|c|c|c|c|}
\hline & \multicolumn{3}{|c|}{ Juneau } & \multirow[t]{2}{*}{$\begin{array}{l}\text { Average } \\
\text { basalt }\end{array}$} & \multirow[t]{2}{*}{$\begin{array}{l}\text { Average olivine } \\
\text { tholeite }\end{array}$} \\
\hline & $\begin{array}{c}\text { Arithmetic } \\
\text { mean }\end{array}$ & Range & $\begin{array}{l}\text { Standard } \\
\text { deviation }\end{array}$ & & \\
\hline Cobalt----- & 62 & $25-95$ & 17 & 40 & 43 \\
\hline Chromium--- & 207 & $46-340$ & 88 & 162 & 210 \\
\hline Copper----- & 92 & $36-200$ & 38 & 119 & 75 \\
\hline Nickel-- --- & 62 & $22-220$ & 39 & 88 & 126 \\
\hline Scandium--- & 44 & $21-74$ & 12 & 27 & 26 \\
\hline Vanadium--- & 222 & $140-280$ & 30 & 247 & 183 \\
\hline Palladium-- & 0.012 & tr.- 0.019 & 90.003 & & \\
\hline
\end{tabular}

samples. The reported averages were calculated using only determined values and neglecting those below limits of determinability. On a similar basis, palladium and platinum contents of the Juneau samples respectively average $12 \mathrm{ppb}$ and $10 \mathrm{ppb}$, and the average $\mathrm{Pt}: \mathrm{Pd}$ and $\mathrm{Pt}:(\mathrm{Pt}+\mathrm{Pd})$ ratios are respectively 0.83 and 0.47 . These averages indicate that the metavolcanic rocks in the Ketchikan area are enriched considerably in platinum compared to the rocks near Juneau and that the rocks from both areas are virtually identical in palladium, as well as rhodium, content.

Averages calculated as the preceding ones may, however, be misleadingly high, depending on the percentage of samples that contain an element below its limit of detectability. More realistic averages are obtained, we believe, by using all data and assuming a value of half the limit of determinability for all results below this limit. Calculated on this basis, average contents of palladium and platinum in the Juneau samples are respectively $12 \mathrm{ppb}$ and $6 \mathrm{ppb}$, and average $\mathrm{Pt}: \mathrm{Pd}$ and $\mathrm{Pt}:(\mathrm{Pt}+\mathrm{Pd})$ ratios are 0.51 and 0.34 . For comparison, averages recaiculated similarly for the metavolcanic rocks from Ketchikan, from data in Page, Berg, and Haffty (1977), are as follows: palladium, $8 \mathrm{ppb}$; platinum, $7 \mathrm{ppb}$; $\mathrm{Pt}: \mathrm{Pd}$, 0.88; and $\mathrm{Pt}:(\mathrm{Pt}+\mathrm{Pd}), 0.47$. Comparison of these averages shows different relations than the comparison of averages based only on values above limits of determinability, owing to the much greater percentage of samples with determinable palladium in the Juneau suite (97 percent) than in the Ketchikan suite (60 percent). Using these averages, the metavolcanic rocks from both areas have nearly the same platinum content, but those from Juneau are considerably enriched in palladium.

The cogenetic relation of the late Mesozoic volcanism and Alaskan-type mafic and ultramafic plutonism (Berg and others, 1972; Irvine, 1973) is supported by similarities in platinum, palladium, and rhodium ratios (Page and others, 1977). The Alaskan-type complexes are concentrated mainly in the southern part of the volcanic belt, and none occurs within the terrane sampled in the present study. Although similar in having low rhodium contents, the metavolcanic rocks in the Juneau and Ketchikan areas differ greatly in their platinum and palladium ratios, which may suggest that the Juneau-area volcanism was not cogenetic with Alaskan-type plutonism, or that 
the ratios were modified by magmatic differentiation or metamorphism. Several small ultramafic complexes are known to occur on the mainland and islands east of Glass Peninsula (Grybeck and others, 1977), but no data are available on their platinum-group metal contents. Alaskan-type complexes elsewhere show a considerable range in platinum and palladium ratios, and therefore we consider our data inconclusive for showing a genetic relation between volcanism in the Juneau area and Alaskan-type mafic and ultramafic plutonism. The data do indicate, however, distinct regional variations in platinumgroup metal characteristics within this late Mesozoic volcanic belt in southeast Alaska.

The content of other analyzed minor metals is about normal for rocks of basaltic composition, particularly of the olivine tholeiite type, except for comparatively low nickel abundance (table 4). These results support earlier conclusions (Ford and Brew, 1977b) that the late Mesozoic volcanic terrane near Juneau is compositionally unlike the andesitic terranes of the northern and southern parts of the Gravina-Nutzotin belt. The tectonic setting of this volcanism in the Juneau area is enigmatic. Tholeiitic volcanism may have been of the island-arc type, but present data do not preclude other possibilities, such as an ocean island, or a marginal ocean basin setting.

\section{REFERENCES CITED}

Berg, H. C., Jones, D. L., and Richter, D. H., 1972, GravinaNutzotin belt-tectonic significance of an upper Mesozoic sedimentary and volcanic sequence in southern and southeastern Alaska, in Geological Survey research, 1972: U.S. Geol. Survey Prof. Paper 800-D, p. Dl-D24.

Brew, D. A., and Ford, A. B., 1974, Geology of the Juneau Icefield and adjacent areas, in Carter, Claire, ed., U.S. Geological Survey Alaska program, 1974: U.S. Geol. Survey Circ. 700, p. 54-56.

Connelly, William, 1976, Mesozoic geology of the Kodiak Islands and its bearing on the tectonics of southern Alaska: Santa Cruz, California Univ., Ph. D. thesis, 197 p.

Ford, A. B., and Brew, D. A., 1977a, Truncation of regional metamorphic zonation pattern of the Juneau, Alaska, area by the Coast Range batholith, in Blean, K.M., Ed., The United States Geological Survey in Alaska; accomplishments during 1976: U.S. Geol. Survey Circ. 751-B, p. B85-B87.

1977b, Chemical nature of Cretaceous greenstone near Juneau, Alaska, in Blean, K.M., ed., The United States Geological Survey in Alaska; accomplishments during 1976: U.S. Geol. Survey Circ. 751-B, p. B88-B90.
Grybeck, Donald, Brew, D. A., Johnson, B. R., and Nutt, C. J., 1977, Ultramafic rocks in part of the Coast Range batholithic complex, southeastern Alaska, in Blean, K.M., ed., The United States Geological Survey in Alaska; accomplishments during 1976: U.S. Geol. Survey Circ. 751-B, p. B82-B85.

Irvine, T. N., 1973, Bridget Cove volcanics, Juneau area, Alaska; possible parental magma of Alaskan-type ultramafic complexes: Carnegie Inst. Washington Yearbook 72, p. 478-491.

Lathram, E. H., Pomeroy, J. S., Berg, H. C., and Loney, R. A., 1965, Reconnaissance geology of Admiralty Island, Alaska: U.S. Geol. Survey Bull. 1181-R, 48 p.

Page, N. J, Berg, H. C., and Haffty, Joseph, 1977, Platinum, palladium, and rhodium in volcanic and plutonic rocks from the Gravina-Nutzotin belt, Alaska: U.S. Geol. Survey Jour. Research, v. 5, p. 629-636.

Prinz, Martin, 1967, Geochemistry of basaltic rocks; trace elements, in Hess, H.H., and Poldervaart, Arie, eds., Basalts, Vol. 1: New York, John Wiley, p. 271-323.

Intrusive rocks in the Fairweather Range, Glacier Bay National Monument, Alaska

By David A. Brew, Bruce R. Johnson, Arthur B. Ford and Robert P. Morrell

Completion of reconnaissance geologic mapping in the high part of the Fairweather Range, Alaska, indicates that about 30 percent of the Fairweather province (fig. 42), as defined by MacKevett and others (1971) is underlain by intrusive rocks of diverse types and ages (fig. 42). The oldest group of intrusive rocks consists of layered gabbros of inferred Precambrian or early Paleozoic age (Brew and others, 1977) that form an irregular belt along the axis of the range. Locally foliated granitic rocks of inferred Cretaceous or Tertiary age occur within the gabbro belt and to the east toward Johns Hopkins Inlet. Bodies of unfoliated granitic rocks of inferred middle Tertiary age form another irregular belt generally to the east of the gabbro belt, but overlapping to the south. Extensive bodies of wellfoliated granitic rocks of inferred Cretaceous age are exposed in the Coastal province to the west of the Fairweather province and in the Geikie province to the east.

The cumulus-type layered gabbros mainly intrude a regionally extensive hornblende schist and gneiss unit (D. A. Brew, unpub. data, 1978). The compositions of the different bodies appear to vary significantly only in hornblende, magnetite, and ilmenite content. In general, the cumulates are fine- to coarse-grained, light- to darkgray and brown (olivine-) gabbro, gabbronorite, and norite, which have color indices of 40 to 80 


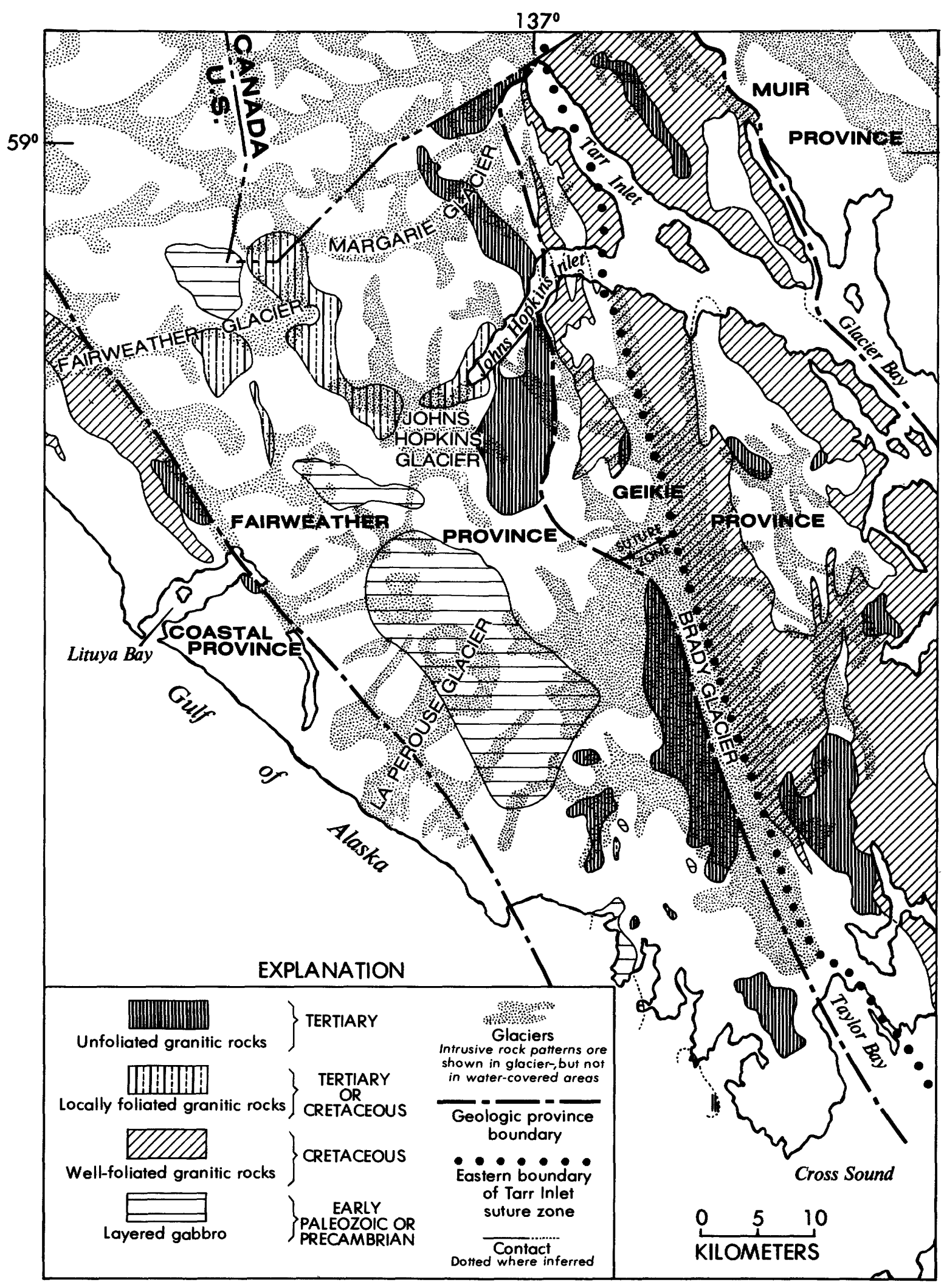

FIGURE 42.-Sketch map of western Glacier Bay National Monument, showing geologic provinces, intrusive rocks, and Tarr Inlet suture zone. All associated migmatites are included within the intrusive rock bodies shown. 
and contain local layers of pyroxenite. The layering is crude to moderately well developed in most places, but is very well developed locally. The most complete descriptions of these rocks are given by Rossman (1963) and Plafker and MacKevett (1970).

The locally foliated granitic rocks of inferred Cretaceous or Tertiary age intrude mainly a regionally extensive biotite schist unit (D. A. Brew, unpub. data, 1978) and have extensive stockwork-type migmatites associated with them. The most common rock types are fine- to mediumgrained, light-gray (hornblende-) biotite quartz diorite, tonalite, granodiorite, and diorite, with color indices of 20 to 30 .

In the Fairweather province, the unfoliated granitic rocks of inferred middle Tertiary age mainly intrude regionally extensive biotite schist and gneiss units as well as the phyllite and graywacke semischist that is the protolith of those units. Spectacular stockwork and irregular banded gneiss migmatites are associated with almost all of the bodies. A wide variety of rock types is present; most common are mediumto-coarse-grained, light-gray (garnet-) (hornblende-) biotite granodiorite, granite, and tonalite, with color indices of 8 to 15. Some bodies are locally prophyritic.

The distribution of the different groups of intrusive rocks in the Fairweather and adjacent Coastal and Geikie provinces suggests several possible relations. First is the already described (Brew and others, 1977) restriction of the layered gabbros to the lithically monotonous country rock of the Fairweather province and the similar restriction of the locally foliated granitic rocks of Cretaceous or Tertiary age. The absence of the well-foliated granitic rocks of inferred middle Cretaceous age from the lithically monotonous rocks of the Fairweather province suggests that the area was somehow isolated from the very wide-spread plutonism that affected southeastern Alaska at that time (Brew and others, 1966; Loney and others, 1975). The middle Cretaceous plutonism characterizes the Geikie province, including the Tarr Inlet suture zone (fig. 42) as described in the accompanying article (Brew and Morrell, 1978).

The location of the greatest volume of granitic rocks of inferred middle Tertiary age close to the Tarr Inlet suture zone (fig. 42; also D. A. Brew, unpub. data, 1978) suggests that the zone was a conduit for magmas generated near the continental margin during the middle Tertiary, a time of significant compressional strike-slip motion along the North American plate at this latitude (Atwater, 1970). Most simple plate tectonic models, however, require subduction at a continental margin to generate magmas (Dickinson, 1972).

\section{REFERENCES CITED}

Atwater, Tanya, 1970, Implications of plate tectonics in the Cenozoic tectonic evolution of western North America: Geol. Soc. America Bull., v. 81, p. 3513-3535.

Brew, D. A., Loney, R. A., Kistler, R. W., Czamanske, G. K., Grommé, C. S., and Tatsumoto, M., 1977, Probable Precambrian or lower Paleozoic rocks in the Fairweather Range, Glacier Bay National Monument, Alaska, in Blean, K. M., ed., The United States Geologial Survey in Alaska; accomplishments during 1976: U.S. Geol. Survey Circ. 751-B, p. B91-B93.

Brew, D. A., Loney, R. A., and Muffler, L. J. P., 1966, Tectonic history of southeastern Alaska: Canadian Inst. Mining and Metallurgy Spec. Vol. 8, p. 149-170.

Brew, D. A., and Morrell, R. P., 1978, Tarr Inlet suture zone, Glacier Bay National Monument, Alaska, in Johnson, K. M., ed., The United States Geological Survey in Alaska; accomplishments during 1977: U.S. Geol. Survey Circ. 772-B, p. B90.

Dickinson, W. R., 1972, Evidence for plate-tectonic regimes in the rock record: Amer. Jour. Science, v. 272, p. 551576.

Loney, R. A., Brew, D. A., Muffler, L. J. P., and Pomeroy, J. S., 1975, Reconnaissnace geology of Chichagof, Baranof, and Kruzof Islands, southern Alaska: U.S. Geol. Survey Prof. Paper 792, $105 \mathrm{p}$.

MacKevett, E. M., Jr., Brew, D. A., Hawley, C. C., Huff, L. C., and Smith, J. G., 1971, Mineral resources of Glacier Bay National Monument, Alaska: U.S. Geol. Survey Prof. Paper 632, 90 p.

Plafker, George, and MacKevett, E. M., Jr., 1970, Mafic and ultramafic rocks from a layered pluton at Mount Fairweather, Alaska, in Geological Survey research 1970: U.S. Geol. Survey Prof. Paper 700-B, p. B21--B26.

Rossman, D.L., 1963, Geology and petrology of two stocks of layered gabbro in the Fairweather Range, Alaska: U.S. Geol. Survey Bull. 1121-F, 50 p.

Tarr Inlet suture zone, Glacier Bay National Monument, Alaska

By David A. Brew and Robert P. Morrell

Recent reconnaissance geologic mapping west of Tarr Inlet in Glacier Bay National Monument and previous mapping to the south as far as Taylor Bay on Icy Strait suggest that a 5- to $12-\mathrm{km}$ wide and at least $100-\mathrm{km}$-long zone of complex geology between the predominantly metamorphic rocks of the Fairweather province (MacKevett and others, 1971) to the west and the 
predominantly intrusive rocks of the Geikie province to the east represents a suture between significantly different terranes (fig. 42).

The Fairweather Range consists of about 30 percent intrusive rocks of diverse types and ages (Brew and others, 1978), 25 percent hornblende schist and gneiss in one regionally continuous unit, and 45 percent biotite schist and gneiss and protolithic graywacke semischist and phyllite. The country rocks in the range are probably of Precambrian or early Paleozoic age (Brew and others, 1977) and were deposited as a thick pile of marine graywacke and shale with interbedded thick volcanic flows or sills of intermediate composition to the west.

Fold structures in the country rock are poorly understood, but the complexity of folding appears to decrease from west to east. The western part of the range is characterized by steeplimbed isoclinal folds with northwest-striking nearly vertical axial planes and moderately plunging axes. These folds appear to have refolded an earlier generation of folds, but the original orientations have not been determined. To the east, toward the suture zone, both steepand shallow-limbed folds with north-northweststriking nearly verticaly axial planes and moderately plunging axes are present. Fewer key layers are present than to the west, and earlier folds have not been recognized.

The rocks of the Geikie province, east of the suture zone, consist of a varity of Cretaceous and Tertiary granitic rocks which altogether underlie about 60 percent of the province. The country rocks are a diverse assemblage of hornfelsed pelitic and semipelitic rock, marble and greenstone, and amphibolite: underlying approximately 30 , 25 , and 2 percent, respectively, of the whole province (the remaining 3 percent is the suture zone itself, which is included in the Geikie province). These country rocks are inferred to be of middle Paleozoic age on the basis of their probable equivalence to fossiliferous rocks in the Chilkat province adjacent to the east. These rocks were probably deposited as a thick section of marine shale, graywacke, arkose, volcanic flows or tuffs, and limestone (Rossman, 1963; MacKevett and others, 1971) in a shallower environment than that of the older rocks in the Fairweather province. The most complete descriptions of the country rocks available are in Rossman (1963) and Seitz (1959).
According to both Rossman and Seitz, fold structures in the Geikie province cannot be generalized very well owing mainly to the large amounts of intrusive rocks that are present, faulting, and the resulting discontinuity of units. Our impression is that the folds are simpler than those in the Fairweather Range, but this simplicity cannot be clearly documented.

The suture zone itself, where best exposed in the Tarr Inlet-Johns Hopkins Inlet area, is underlain by about 20 percent elongated bodies of highly foliated biotite-hornblende quartz diorite whose age is inferred to be Cretaceous, the same as the dominant intrusive rock throughout the Geikie province. The country rocks consist of about 40 percent phyllite, slate, conglomerate, and chert in units that are continuous and coherent at kilometer scale, but that have many internal discontinuities of individual lithic units; 30 percent greenstone, greenschist and other metavolcanic rocks that are apparently more coherent internally; and 10 percent gray marble in lenses that range in size from a few meters in maximum exposed dimension to as much as $5 \mathrm{~km}$ long and several tens of meters thick. These country rocks are unfossiliferous and their age is unknown. On the basis of general proportions and similarity of lithic types, we suggest that they may be eqivalent to a fossiliferous Permian unit exposed in the northeastern part of the monument (D. A. Brew, unpub. data, 1978). The rocks in the suture zone appear to have been deposited as shale, conglomerate, graywacke, tuffs or flows, chert, and thin limestones in a marine environment.

Fold orientations in the suture zone appear to vary from unit to unit. Some of the marble layers have small folds with shallow plunges and northstriking, moderately west-dipping axial planes. A 1-km-long marble layer within a dominantly phyllitic unit apparently defines a macrofold of about the same orientation. Although the fold situation in the greenstones is poorly known, one of the larger units is characterized by relatively simple chevron and conjugate kink folds. One of the most significant structural features in the zone is the discontinuity of individual layers within the mappable units and the abundance of relatively small (a few kilometers long by a few hundred kilometers thick) units. Some of these may be inherited from the original depositional environment, but tectonic disruption is considered a more likely cause. 
The suture zone as presently mapped (fig. 42) widens westward in the northern reaches of the Brady Glacier, but the geology of that area is not well known, and it is possible that rocks inferred to belong to the zone are instead part of the Fairweather province. In the vicinity of Taylor Bay the zone is probably no more than $5 \mathrm{~km}$ wide (fig. 42) and consists of greenschist and greenstone with minor marble, chert, and graywacke semischist, bounded on the west beneath the Brady Glacier by graywacke semischist and slate of the Fairweather province and on the east by locally garnet-bearing amphibolite and gneiss.

The suture zone extends north into British Columbia underneath the Grand Pacific Glacier; no geologic mapping is available for about $100 \mathrm{~km}$ in that direction. To the south the zone projects towards the Inian Peninsula on Chichagof Island, which Loney, Brew, Muffler, and Pomeroy (1975) show as dominantly Mesozoic country rocks to the west separated by intrusive rocks from probably middle Paleozoic country rocks to the east. Plafker, Jones, Hudson, and Berg (1976) consider the Inian Peninsula to be east of the Border Ranges fault, which they infer to be "a late Mesozoic plate boundary that juxtaposes regionally metamorphosed upper Paleozoic rocks on the north(east) against predominantly upper Mesozoic deep marine rocks" (p. 14) on the southwest. The questions concerning the southward extension of the suture zone and of the Fairweather province rocks into Chichagof Island cannot be answered without more field study.

The available evidence and the interpretations given here suggest that the Tarr Inlet suture zone resulted from the collision, sometime between Permian and middle Cretaceous, of a block of probable Precambrian or lower Paleozoic rocks to the west with the large block of middle Paleozoic rocks to the east; the middle Paleozoic rocks are the essential element (Brew and others, 1966) of what is now called the Alexander terrane (Berg and others, 1972). This suggested collision zone is within the Alexander terrane as presently defined in this region, and its role in larger tectonic models is not clear.

\section{REFERENCES CITED}

Berg, H. C., Jones, D. L., and Richter, D. H., 1972, GravinaNutzotin belt-tectonic significance of an upper Mesozoic sedimentary and volcanic sequence in southern and southeastern Alaska, in Geol. Survey Prof. Paper 800-D, p. D1-D24.

Brew, D. A., Johnson, B. R., Ford, A. B., and Morrell, R. P., 1978, Intrusive rocks in the Fairweather Range, Glacier Bay National Monument, Alaska, in Johnson, K.M., ed., The United States Geological Survey in Alaska; accomplishments during 1977: U.S. Geol. Survey Circ. 772-B, p. B88.

Brew, D. A., Loney, R. A., Kistler, R. W., Czamanske, G. K., Grommé, C. S., and Tatsumoto, M., 1977, Probable Precambrian or lower Paleozoic rocks in the Fairweather Range, Glacier Bay National Monument, Alaska, in Blean, K. M., ed., The United States Geological Survey in Alaska; accomplishments during 1976: U.S. Geol. Survey Circ. 751-B, p. 91-93.

Brew, D. A., Loney, R. A., and Muffler, L. J. P., 1966, Tectonic history of southeastern Alaska: C. I. M. Spec. Vol. 8, p. $140-170$.

Loney, R. A., Brew, D. A., Muffler, L. J. P., and Pomeroy, J. S., 1975, Reconnaissance geology of Chichagof, Baranof, and Kruzof Islands, Alaska: U.S. Geol. Survey Prof. Paper 792, $105 \mathrm{p}$.

MacKevett, E. M., Jr., Brew, D. A., Hawley, C. C., Huff, L. C., and Smith, J. G., 1971, Mineral resources of Glacier Bay National Monument, Alaska: U.S. Geol. Survey Prof. Paper 632, 90 p.

Plafker, George, Jones, D. L., Hudson, Travis, and Berg, H. C., 1976, The Border Range fault system in the Saint Elias Mountains and Alexander Archipelago, in Cobb, E. H., ed., The United States Geological Survey in Alaska; accomplishments during 1975: U.S. Geol. Survey Circ. 733, p. 14-16.

Rossman, D. L., 1963, Geology of the eastern part of the Mount Fairweather quadrangle, Glacier Bay, Alaska: U.S. Geol. Survey Bull. 1121-K, 57 p.

Sietz, J. F., 1959, Geology of Geikie Inlet area, Glacier Bay, Alaska: U.S. Geol. Survey Bull. 1058-C, p. 61-120.

\section{OFFSHORE ALASKA}

Heat flow and organic gas measurements from the Aleutian Basin, Bering Sea

By Alan K. Cooper

The Aleutian Basin is one of the three deepwater (more than $3,000 \mathrm{~m}$ ) sedimentary basins that lie north of the Aleutian Ridge. Several geologic and geophysical observations made by investigators working in the Aleutian Basin (summarized in Cooper and others, 1978), when considered collectively, suggest that the basin is a promising area for hydrocarbon exploration. Observations relevant to the existence of hydrocarbon accumulations include the following: 1) the basin contains a thick section of mostly Cenozoic sedimentary deposits (2 to $9 \mathrm{~km}$ thick) overlying an igneous oceanic crustal section; 2) potentially high thermal gradients exist in the sedimentary section; 3 ) structural features (dia- 
pirs, faults, basement ridges) are present throughout the basin; 4) the sedimentary section contains potential source and reservoir beds; and 5) within the central part of the basin are abundant VAMPs (velocity amplitude features), which may be caused by trapped gases within the sedimentary section.

As part of the ongoing program for identifying and investigating promising areas for new energy resources, a combined geologic and geophysical cruise (S3-77-BS) was conducted within the Aleutian Basin aboard the U.S.G.S. research vessel Sea Sounder during the first two weeks in June 1977. The primary objective of the cruise was to measure both the heat flow and the concentration of organic gases in surface sediment at sites in the central Aleutian Basin that had been surveyed with high-energy seismic reflection profiles during a cruise (L5-76-BS) in 1976 (Cooper, 1977). A secondary objective was to collect seismic reflection data between sample stations and use these data to delineate more accurately both the zone of VAMPs and the region of irregular buried basement relief.

The cruise was highly successful, primarily owing to the diligent efforts of the ship's crew and scientific staff, and the excellent weather. A total of 26 sample attempts (fig. 43) were made with a 3-m gravity corer equipped with outrigger thermal probes; 19 sediment cores, 6 heat flow measurements, and 8 organic gas analyses were obtained. Nearly $4,000 \mathrm{~km}$ of underway geophysical records (single-channel seismic reflection, gravity, magnetics) was collected.

Analyses of most sediment core data were done onboard ship by U.S.G.S. scientists. George Redden conducted the organic gas analyses of the freshly recovered sediment using special procedures and equipment designed by Keith Kvenvolden's marine organic geochemistry group. The thermal conductivity of the sediment was measured by Vaughn Marshall and Jon Childs with a computer-activated needle probe built especially for the cruise by Jim Chan, from plans supplied by Art Lachenbruch's heat flow group.

Heat flow values in the central Aleutian Basin range from 1.2 to $1.7 \mu \mathrm{cal} / \mathrm{cm}^{2} / \mathrm{s}$ and average 1.45 $\pm 0.16 \mu \mathrm{cal} / \mathrm{cm}^{2} / \mathrm{s}$. The values are not correlated with the buried basement relief (heat flow values are not greater on top of basement ridges); thus the small variations in heat flow may be caused by regional subcrustal temperature variations

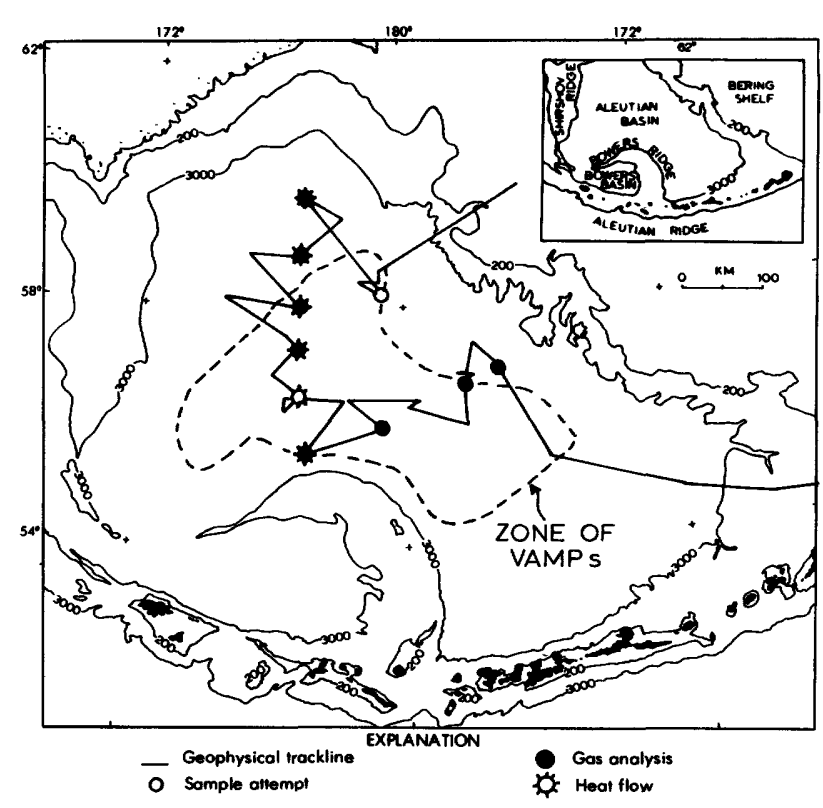

FIGURE 43.-Bathymetric map of the Aleutian Basin, Bering Sea, showing geophysical tracklines and geologic sampling sites occupied during June 1977. Bathymetric contours in meters.

rather than local intrusive heat sources. Thermal conductivity of the sediment, primarily silty diatomaceous ooze, ranges from 1.66 to 4.49 mcal $\mathrm{cm} \times \mathrm{s} \times{ }^{\circ} \mathrm{C}$

than $2.5 \frac{\mathrm{mcal}}{\mathrm{cm} \times \mathrm{s} \times{ }^{\circ} \mathrm{C}}$ are found in thin layers (5$20 \mathrm{~cm}$ thick) of fine-grained silica and heavymineral sand; the well-sorted sand layers constitute 8 to 10 percent of the sediment in the cores and appear to be the result of widespread turbidity currents in the abyssal basin.

The primary constituent of the organic gases, which are totally dissolved in the interstitial waters, is methane. The concentration of methane always increases with depth in the cores and is higher, at comparable sub-bottom depths, inside the zone of VAMPs. The largest concentration of methane is found directly over a VAMP. The origin of the methane is unknown and could be either from in situ biogenic generation of the gas or from upward migration of petrogenic gases originating from deeply buried hydrocarbon deposits.

A buried basement ridge ( $30 \mathrm{~km}$ long, $10 \mathrm{~km}$ wide, $3 \mathrm{~km}$ relief) was discovered during the cruise in the northeastern Aleutian Basin. The ridge, which has been named Sounder Ridge after the U.S.G.S. research vessel Sea Sounder, is similar to other buried ridges in the same area 
in that it has had a complex constructional history that may range from early to late Cenozoic time.

The highly successful 1977 field season has provided additional insight into the regional geologic and geophysical framework of the Aleutian Basin, especially those aspects pertaining to potential hydrocarbon resources in the basin.

\section{REFERENCES CITED}

Cooper, A. K., 1977, Marine geophysical investigation in the Bering Sea Basin, in Blean, K. M., ed., The United States Geological Survey in Alaska; accomplishments during 1976: U.S. Geol. Survey Circ. 751-B, p. B98B100.

Cooper, A. K., Scholl, D. W., Marlow, M. S., Childs, J. R., Redden, G., and Kvenvolden, K., 1978, The Aleutian Basin, Bering Sea-a frontier area for hydrocarbon exploration: Offshore Technology Conf. Proc., May 1978, preprint.

Environmental geologic studies in northern Bering Sea

By Devin R. Thor and Hans Nelson

A three-week cruise to the northern Bering Sea during July 1977 covered $2,900 \mathrm{~km}$ of geophysical tracklines and collected $3.5-\mathrm{kHz}, 12$ $\mathrm{kHz}, 200-\mathrm{kHz}$, Uniboom, minisparker, side-scan sonar, and 120-kj single channel sparker seismic data. At 48 stations, 29 box cores, 10 vibracores, and 100 Soutar van Veen grab samples were collected (Thor, 1978).

Environmental evaluation of geologic phenomena in northern Bering Sea indicates that faulting, ice gouging, bottom currents, storm surges, and gas-charged sediments pose problems with development of offshore resources (Nelson and Thor, 1977) (fig. 44). Surface and near-surface faults are conspicuous, but Holocene fault activity is difficult to determine because strong current scour may be preserving or exhuming old scarps. Surface and near-surface faulting south of Nome seems to be associated with thermogenic gas seeps (Nelson and Kvenvolden, 1978). Analysis of gas from $2-m$ vibracore sediment samples showed anomalously high concentrations of hydrocarbons heavier than methane. The ratio of methane to ethane plus propane reached a minimum value of 7 at the bottom of a 1.6-m-long core. Maximum concentrations of ethane, propane, $n$-butane, and isobutane were $76,3,6$, and 52 times greater, respectively, than the maximum concentrations of these gases

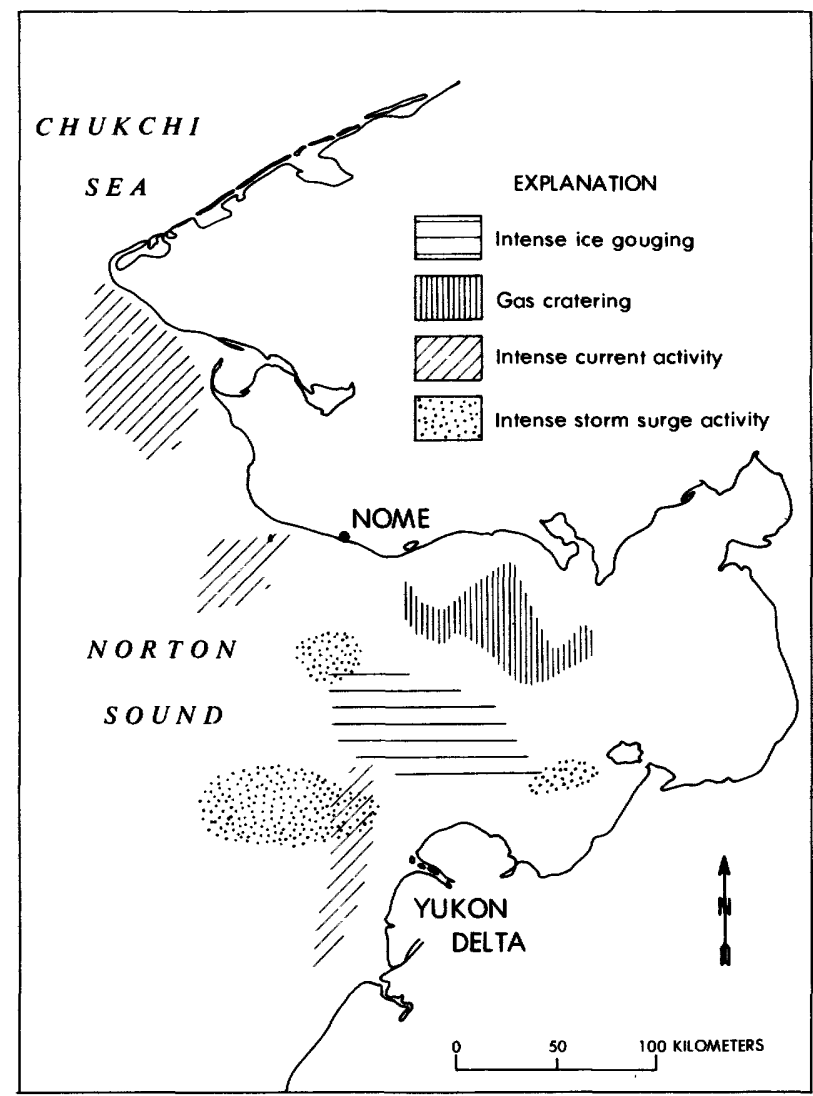

FIGURE 44.-Potentially hazardous regions, northern Bering Sea.

found in surrounding baseline stations. As further support for the seep, the occurrence of a deep subsurface anomaly at $100 \mathrm{~m}$ suggests the presence of a large subsurface gas cap greater than $10 \mathrm{~km}$ in diameter. High-resolution seismic profiles show surface termination of subbottom reflectors under a region of $2 \mathrm{~km}^{2}$ in the area where the vibracore was obtained. These data indicate a potential petroleum resource with a known area of surface escape from the large underlying gas cap and a potential hazard for future drilling activity in this area.

Ice scouring of bottom sediment occurs throughout northeastern Bering Sea where water depths are less than $20 \mathrm{~m}$ (Thor and others, 1977). Ice gouge furrows reach a maximum depth of $0.75 \mathrm{~m}$ in bottom sediment and occur most commonly as solitary gouges. Pressure ridge raking, most commonly around the shoals of the $\mathrm{Yu}$ kon Delta is caused by a well-developed shear zone of offshore pack ice. Ice gouging affects 
most of Norton Sound to some degree but is most intense in the Yukon Delta. Much of the gouging in the sound probably is caused by allochthonous ice from northern Bering and(or) southern Chukchi Seas. Ice brought into the sound during springtime, by a combination of cyclonic watercurrent gyre and winds, grounds in the shallow water of the prodelta.

Sand waves, 1 to $2 \mathrm{~m}$ high with wavelengths of 10 to 20 or 150 to $200 \mathrm{~m}$, and ripples, $4 \mathrm{~cm}$ high with $20-\mathrm{cm}$ wavelength, occupy the crests and some flanks of a series of large, linear ridges lying west of the Port Clarence area (Field and others, 1977; Nelson and others, 1977; Cacchione and others, 1977). Ice gouges in varying states of preservation on several ridges indicate active sand wave modification and recent movement. Survey tracklines of 1976 were replicated in 1977 , and local changes in bedform type and trend further substantiate recent bedform activity. Sand wave movement and bedload transport seem to occur during calm weather; maximum change may take place when northerly current flow is enhanced by sea level set-up from major southwesterly storms. Strong north winds from the Arctic, however, reduce the strength of the continuous northerly currents and thereby decrease the amount of bedload transport and activity of mobile bedforms near Bering Strait. Evidence from the most recent storm-surge event, in 1974, suggests that severe storms also cause major scour and movement of sand sheets over wide areas of southern Norton Sound.

A series of large (25 to $150 \mathrm{~m}$ in diameter), irregularly shaped, shallow (less than $1 \mathrm{~m}$ ) depressions in Yukon-derived silty to sandy mud occurs along the southwestern margin of the Yukon Delta and on the flanks of an extensive shallow trough in north-central Norton Sound. They usually are associated with increased bottom steepness and regions of higher bottom current speeds. Some of the northern depressions are found near sea-floor scarps of unknown origin; those to the southwest on the prodelta front are clearly associated with ice-gouge furrows. Apparently, in regions where current speed is increased because of constriction of water flow along flanks of troughs, shoals, or delta fronts, any further disruption of current flow by slump scarps or icegouge furrows initiates scour of the Yukon Riverderived sediments, forming large shallow depressions.
Small (3 to $8 \mathrm{~m}$ in diameter) circular craters observed on sonographs over a large area of north-central Norton Sound may be formed by gas venting during major storm wave stress on the sea floor (Hans Nelson and others, unpub. data, 1977). Vibracore samples and acoustic anomalies in high-resolution seismic profiles indicate that craters are associated with a thin cover of Holocene Yukon mud overlying nearsurface freshwater peaty muds and gas-rich sediment. Abnormally high amounts of methane gas generated by the buried organic debris cause gas charging of the near-surface sediments. Gas venting and cratering, particularly during peak storm periods, have been associated with pipeline breaks in the oil-producing regions of the North Sea and the Gulf of Mexico.

In conclusion, present knowledge suggests that the Yukon Delta and eastern Bering Strait areas have severe geologic hazards (fig. 44). Faulting and current scour are most intense in Bering Strait. Ice gouge, bottom current, and storm surge activity are intense for a wide area around the shallow prodelta area. Apparent gas cratering occurs throughout central and eastern Norton Sound.

\section{REFERENCES CITED}

Cacchione, D. A., Drake, D. E., and Nelson, Hans, 1977, Sediment transport in Norton Sound, Alaska [abs.]: Am. Geophys. Union, OES, Trans., v. 58, no. 6, p. 408.

Field, M. E., Nelson, Hans, Cacchione, D. A., and Drake, D. E., 1977, Dynamics of bed forms at an epicontinental shelf; northern Bering Sea [abs.]: Am. Geophys. Union, EOS, Trans., v. 58, no. 12 , p. 1162 .

Nelson, Hans, Cacchione, D. A., and Field, M. E., 1977, Complex ridge and trough topography on a shallow currentdominated shelf, northwest Alaska [abs.]: Am. Assoc. Petroleum Geologists Bull., v. 61, p. 817.

Nelson, Hans, and Kvenvolden, K. E., 1978, Thermogenic gas in sediments of Norton Sound, Alaska [abs.]: Offshore Technology Conf., May 1978, preprint (in press).

Nelson, Hans, and Thor, D. R., 1977, Environmental geologic hazards in Norton Basin, Bering Sea [abs.]: Geol. Soc. America, Abs. with Programs, v. 9, p. 1111.

Thor, D. R., 1978, Continuous seismic reflection data, Sea 577-BS Cruise, northern Bering Sea: U.S. Geol. Survey Open-File-Report.

Thor, D. R., Nelson, Hans, and Evans, J. E., 1977, Preliminary assessment of ice gouging in Norton Sound, Alaska, in Environmental assessment of the Alaskan continental shelf: Environmental Research Labs., Natl. Oceanog. and Atmospheric Agency, Dept. Commerce, Ann. Tech. Summary Rept., p. E-1-E-18. (in press). 
Navarin basin, northwest Bering Sea shelf By Mike Marlow

During the summer of 1977 approximately $3,000 \mathrm{~km}$ of geophysical data, including 24-channel seismic reflection profiles, was collected by the R/V S.P. Lee from the northwest Bering Sea shelf (fig. 2, area 10). These data revealed that Navarin basin (Marlow and others, 1976) is actually a complex of three distinct subshelf basins, encompassing an area of $44,000 \mathrm{~km}^{2}$. These basins are each filled with more than $9 \mathrm{~km}$ of sedimentary section and are separated from one another by northwest-trending basement ridges. Along the northern perimeter of the complex, the basin fill has been strongly folded and truncated. Regional studies in nearby Siberia suggest that deformation took place in late Miocene(?) and Pliocene(?) time. In contrast, the central and southern areas of the complex appear to have formed by crustal extension and down-dropping of basement rocks to form grabenlike basins now filled by nearly flat-lying Cenozoic sedimentary rocks.

Along several geophysical lines numerous acoustical anomalies ("bright spots") were detected that may be related to hydrocarbon deposits (gas?) whose size, extent, and commercial value are unknown.

\section{REFERENCE CITED}

Marlow, M. S., Scholl, D. W., Cooper, A. K., and Buffington, E. C., 1976, Structure and evolution of Bering Sea shelf south of St. Lawrence Island: Am. Assoc. Petroleum Geologists Bull., v. 60, p. 161-183.

Seismicity near Icy Bay, Alaska and in the eastern Gulf of Alaska

By Christopher Stephens

The seismicity in the eastern Gulf of Alaska region, on the basis of results of monitoring by the U.S.G.S. seismic network from 1974 to 1976 , is characterized by a scattered distribution of earthquake epicenters. Local concentrations of epicenters do occur, however, such as in the onshore area northeast of Kayak Island, northeast of Icy Bay, and about $50 \mathrm{~km}$ south of Yakutat Bay. Of the 492 earthquakes located during this time period, those with the best control in the solution have depths ranging from a few kilometers to about $35 \mathrm{~km}$. The largest earthquakes had magnitudes of about 4 . A relatively small num- ber of earthquakes were located offshore. In particular, only two of the better located earthquakes had epicenters within $20 \mathrm{~km}$ of the Pamplona Ridge, the site of a series of three magnitude-6 earthquakes in 1970 (Page, 1975). Although the number of earthquakes detected and located offshore may be influenced by station distribution, I believe that the observed pattern in seismicity represents a real contrast in the present level of earthquake activity between onshore and offshore areas.

Northeast of Icy Bay and Kayak Island, the epicenters of the better located earthquakes define two zones of seismicity that have northeast trends and cut across the east-west trends of mapped thrust faults and other structural features. Earthquakes that occurred beneath Icy Bay, at the southwest end of one of these zones, were relocated using a master event technique. The epicenters of the relocated earthquakes have an east-west trend parallel to nearby mapped faults (Bruns and Plafker, 1975) (fig. 45); this trend suggests that in the larger, northeast-trending zone of seismicity, the earthquakes are occurring on several east-west-trending faults.

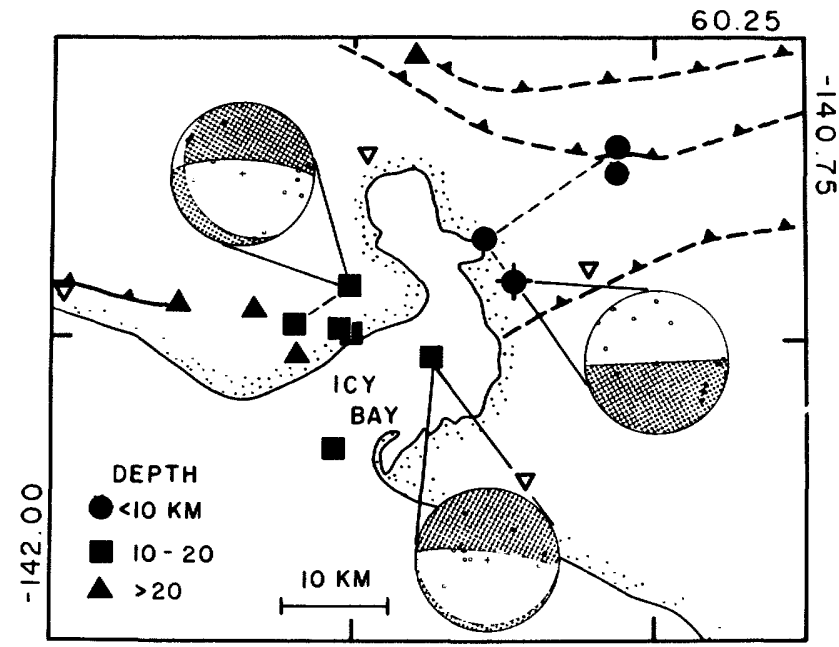

59.75

FIGURE 45.-Epicenters and first-motion plots of the better located earthquakes that occurred beneath Icy Bay, Alaska, between September 1974 and September 1976. The master event used to relocate the earthquakes is shown as a cross. The four closest seismic stations are shown as open, inverted triangles. The heavy dashed and solid lines show mapped and inferred thrust faults, respectively. The light dashed lines join earthquakes used in the same composite first-motion plot. Note the reversal of focal mechanism with increasing depth to the west. 
Composite and single-event first-motion plots for several of the relocated earthquakes that occurred beneath Icy Bay suggest that there is a reversal of focal mechanism at depth in this area. Earthquakes located at depths less than about 10 $\mathrm{km}$ have focal mechanisms consistent with thrusting on a plane dipping steeply to the north, which in turn is consistent with the characteristic large-scale uplift along the eastern Gulf of Alaska. Earthquakes deeper than about $10 \mathrm{~km}$ have focal mechanisms indicating relative motion nearly opposite to that of the shallower earthquakes. The interpretation of the focal mechanisms for the deeper earthquakes is not clear. Although the nodal planes as drawn are consistent with normal faulting on a plane dipping steeply to the north, a change of about $10^{\circ}$ in the dip of the nodal planes for the single event solution would result in a mechanism consistent with thrusting on a plane with a very shallow dip to the north. Marine refraction profiles from immediately south of Icy Bay (Bayer and others, 1977) indicate the presence of a shallow layer, possibly oceanic crust, dipping gently to the north toward Icy Bay. If this layer extends beneath Icy Bay, and if the deeper earthquakes are occurring within this layer, then the radical change in focal mechanism over such a short depth range might be explained.

\section{REFERENGES CITED}

Bayer, K. C., Mattick, R. E., Plafker, George, and Bruns, T. R., 1977, Refraction studies between Icy Bay and Kayak Island, eastern Gulf of Alaska: U.S. Geol. Survey OpenFile Report 77-550, $29 \mathrm{p}$.

Bruns, T. R., and Plafker, George, 1975, Preliminary structural map of part of the Offshore Gulf of Alaska Tertiary Province: U.S. Geol. Survey Open-File Report 75-508, 1 sheet, scale 1:500,000.

Page, R. A., 1975, Evaluation of seismicity and earthquake shaking at offshore site: Offshore Technology Conf., 7th, Houston, Texas, Proc., v. 3, p. 179-190.

Outcrop samples from the Continental Slope in the eastern Gulf of Alaska

By George Plafker, Gary R. Winkler, Susan J. Hunt, Susan Bartsch-Winkler, Warren L. Coonrad, and Paula Quinterno

Between June 5 and June 15, 1977, the R/V Sea Sounder carried out a program of sampling bedrock outcrops along the Continental Slope in the eastern Gulf of Alaska between the eastern end of the Aleutian Trench and the area offshore from Chichagof Island (fig. 46). The samples were to provide geologic control on the seaward margin of the Gulf of Alaska Tertiary Province, a major sedimentary basin that has been of interest for petroleum exploration for many years (Plafker, 1971; Plafker and others, 1975). As of January 1978, part of this basin on the Outer Continental Shelf between Kayak Island and Icy Bay was under lease for petroleum exploration, and eight dry wildcat wells had been drilled for petroleum. Outcrop control along the Continental Slope is essential for delineating the offshore distribution of the potentially petroliferous Tertiary sequence, for understanding facies changes that occur between outcrop sections and wells onshore and the seaward margin of the basin, and for correlation of the Tertiary sequence with seismic reflecting horizons that at many locations appear to intersect the Continental Slope.

Despite persistent mechanical difficulties with the main winch, 16 dredge hauls that are believed to have sampled bedrock outcrops or talus were made in water depths ranging from $3,500 \mathrm{~m}$ to $220 \mathrm{~m}$. Locations for these dredge hauls, which are the first known outcrop samples from the Continental Slope in the Gulf of Alaska, are shown in figure 46 , and selected preliminary sample date are summarized in table 5 . All but seven of these hauls included variable amounts of loose glacial erratics of diverse lithology that most likely were rafted into the Pacific Ocean by ice floes, but in part may have been deposited during former glacial advances close to the edge of the Continental Shelf. In addition, three hauls were made that contained only glacial erratics, two casts were made in which the dredge buckets hung up and were lost, four casts did not recover any sample, and 10 dart cores were attempted, none of which penetrated the surficial mud into indurated sediments.

Preliminary analyses of the lithology, physical properties, and paleontology suggest significant differences in the geology along the Continental Slope, as follows.

\section{Southeast of Cross Sound}

(1) Sample 1 indicates that the upper part of the bedded sequence forming a narrow shelf basin seaward of Chichagof Island includes marine glacial deposits equivalent in lithology and age to the uppermost part of the Yakataga Formation northwest of Cross Sound. 


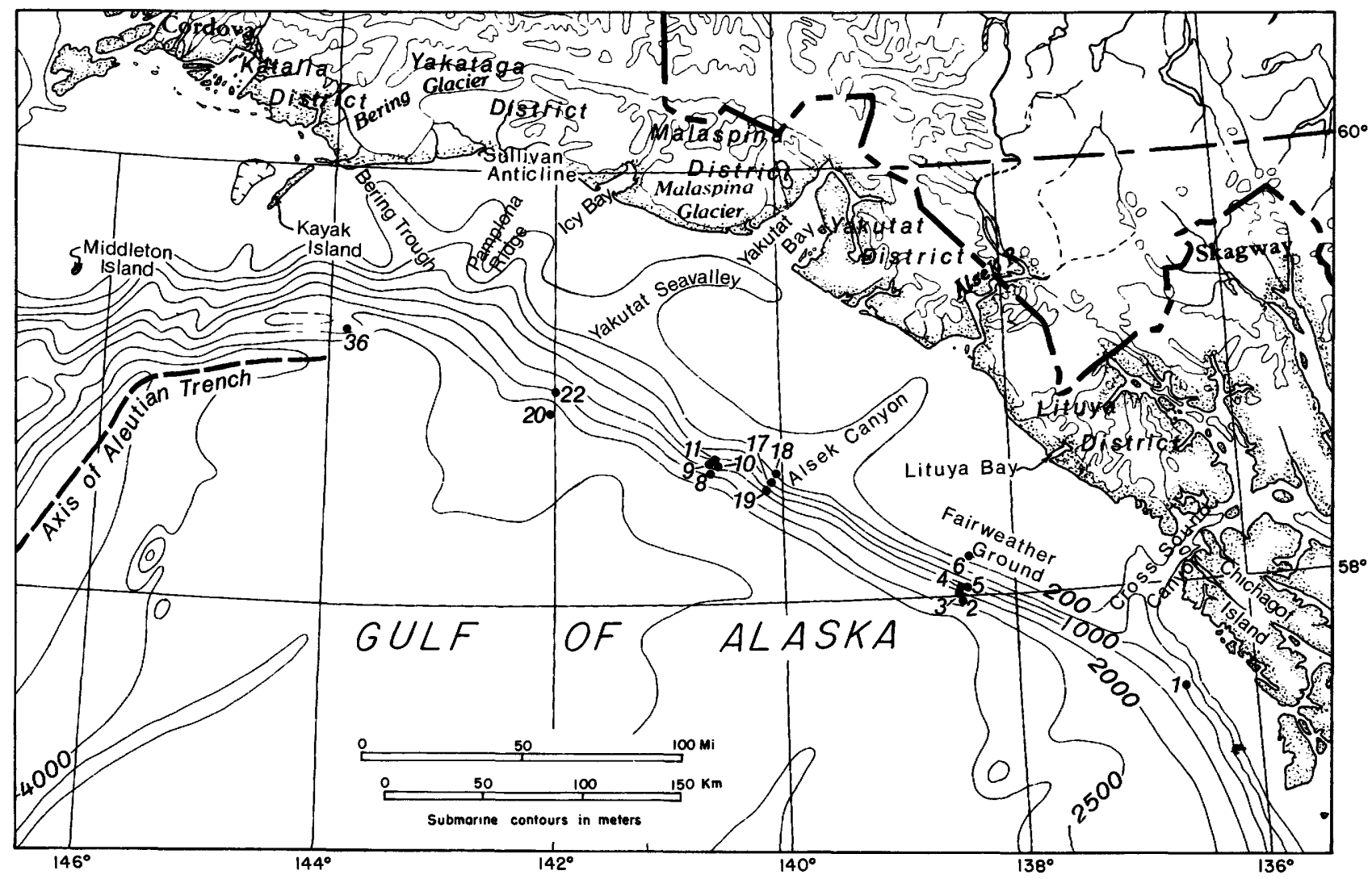

FIGURE 46.-Map showing locations of outcrop dredge samples from the eastern Gulf of Alaska. Numerals indicate samples described in table 6 and the text.

Between Cross Sound and Alsek Canyon

(1) Samples 3 and 6 indicate that much of the Continental Slope off the Fairweather Ground consists of pre-Tertiary outcrops of hard feldspatholithic sandstone, pebbly sandstone, argillite, and greenstone typical of the lithologies of the Yakutat Group on the adjacent mainland.

(2) Sample 4 is lithologically similar to altered diorite that, on the mainland, commonly intrudes the Yakutat Group. However, not enough sample was recovered to be certain that it is from bedrock.

(3) Samples 2 and 5 indicate that sedimentary rocks of late Tertiary or younger age and lithology similar to the Yakataga Formation occur in isolated basins on the pre-Tertiary and crystalline basement rocks in the vicinity of the Fairweather Ground.

(4) The presence of basement rocks, including diorite, suggests the possibility that a broad positive magnetic anomaly centered over the Fairweather Ground described by Naugler and
Wageman (1973) and Taylor and O'Neill (1974) could be related to a major pluton of dioritic composition.

\section{From Alsek Canyon to Yakutat Seavalley}

(1) In this segment of the Outer Continental Shelf, the Tertiary sequence thickens markedly and includes clastic sedimentary rocks ranging in age from late Eocene and possibly older through late Oligocene. This older Tertiary sequence, roughly $3,000 \mathrm{~m}$ thick, lies above probable Cretaceous basement, which has been found in samples 8 and 9 .

(2) The deepest Tertiary(?) sample, number 20 , is an indurated sandy cobble-boulder conglomerate from an outcrop located close to the base of the Continental Slope in water $3,180 \mathrm{~m}-$ $3,080 \mathrm{~m}$ deep. It is not similar in lithology to any known conglomeratic strata that crop out onshore, but the degree of induration suggests that it could be equivalent to one of the Paleocene or Eocene formations. 
(3) Samples 10, 11, 17, 18, and 22 were recovered upslope from the conglomerate and probable Cretaceous outcrops. They consist entirely of siltstone, containing a late Eocene to late Oligocene microfauna, that is interbedded with sandstone. These rocks are probably correlative with the onshore Tokun and Poul Creek Formations.

(4) Microscopic examination of the sandstones suggests that they range from poorly to moderately well sorted, contain abundant unstable rock fragments, have pervasive siliceous or calcareous cement, and have poor to moderate porosity - which probably is secondary.

(5) Preliminary evaluation of the argillaceous components in samples $10,11,17,18,20$ and 22 indicates that all but sample 10 have above average ( $>0.4$ percent) carbon contents with ranges from 0.56 to 1.56 percent carbon. Thermal analysis, however, suggests that the samples have undergone only moderate thermal histories and that organic matter present is predominantly of a chemical type that does not yield liquid hydrocarbons (G. E. Claypool, written commun., 1977).

(6) The highly magnetic greenstone in sample 9 is from an area where aeromagnetic data indicate a strong positive linear magnetic anomaly trending west-northwest toward Kayak Island (Naugler and Wageman, 1973; Taylor and O'Neill, 1974). This anomaly may be caused by a fairly continuous band of spilitized basalt similar to that in sample 9.

(7) A multichannel seismic reflection profile by T. R. Bruns (oral commun., 1978) indicates that the shelf edge is a structural high underlain by Eocene and Oligocene strata that form a wedge dipping and thinning toward the coast. Landward of this high is a broad basin filled with a younger sequence at least $6,000 \mathrm{~m}$ thick, presumably consisting mainly of late Cenozoic Yakataga Formation. The upper part of this younger sequence overlaps the shelf edge high.
Eastern end of Aleutian Trench south of Kayak Island

(1) Sample 36 is from the upper part of a prominent topographic ridge that rises $1,000 \mathrm{~m}$ above the base of the Continental Slope and is separated from the upper Continental Slope by a sediment-filled terrace basin. Single- and multichannel seismic profile data indicate that this ridge is part of a major east-west-trending structural high that extends for at least $60 \mathrm{~km}$ along the base of the slope (T. R. Bruns, oral commun., 1978). The sample consists of blocks of dense and indurated sandy and pebbly siltstone of early Pleistocene age. The siltstone is a deep-water correlative of the uppermost part of the shallow water Yakataga Formation exposed on Middleton Island at the edge of the continental shelf.

(2) The unusually high density of the sample, its occurrence on a topographic and structural high, and the inability to achieve acoustic penetration into the structure with the $160-\mathrm{kj}$ sparker all suggest that sample 36 may have been compacted by tectonic deformation related to crustal plate convergence along the inner wall of the Aleutian Trench.

(3) The prominent topographic high from which sample 36 was collected is probably largely of Quaternary age and hence is unlikely to have any petroleum potential.

\section{REFERENCES CITED}

Naugler, F. P., and Wageman, J. M., 1973, Gulf of Alaska; magnetic anomalies, fracture zones, and plate interaction: Geol. Soc. America Bull., v. 84, p. 1575-1584.

Plafker, George, 1971, Pacific margin Tertiary basin, in Future petroleum provinces of North America: Am. Assoc. Petroleum Geologists Mem. 15, p. 120-135.

Plafker, George, Bruns, T. R., and Page, R. A., 1975, Interim report on petroleum resource potential and geologic hazards in the Outer Continental Shelf of the Gulf of Alaska Tertiary Province: U.S. Geol. Survey Open-File Report 75-592, 74 p.

Taylor, P. T., and O'Neill, N. J., 1974, Results of an aeromagnetic survey in the Gulf of Alaska: Jour. Geophys. Research, v. 9, no. 5, p. 719-723. 
[Ages for samples containing microfossils are based on studies of the foraminifers by W. W. Rau, silicoflagellates by R. G. Poore, and nannoplankton by David Bukry. All other ages are inferred by lithologic comparison with rocks onshorel

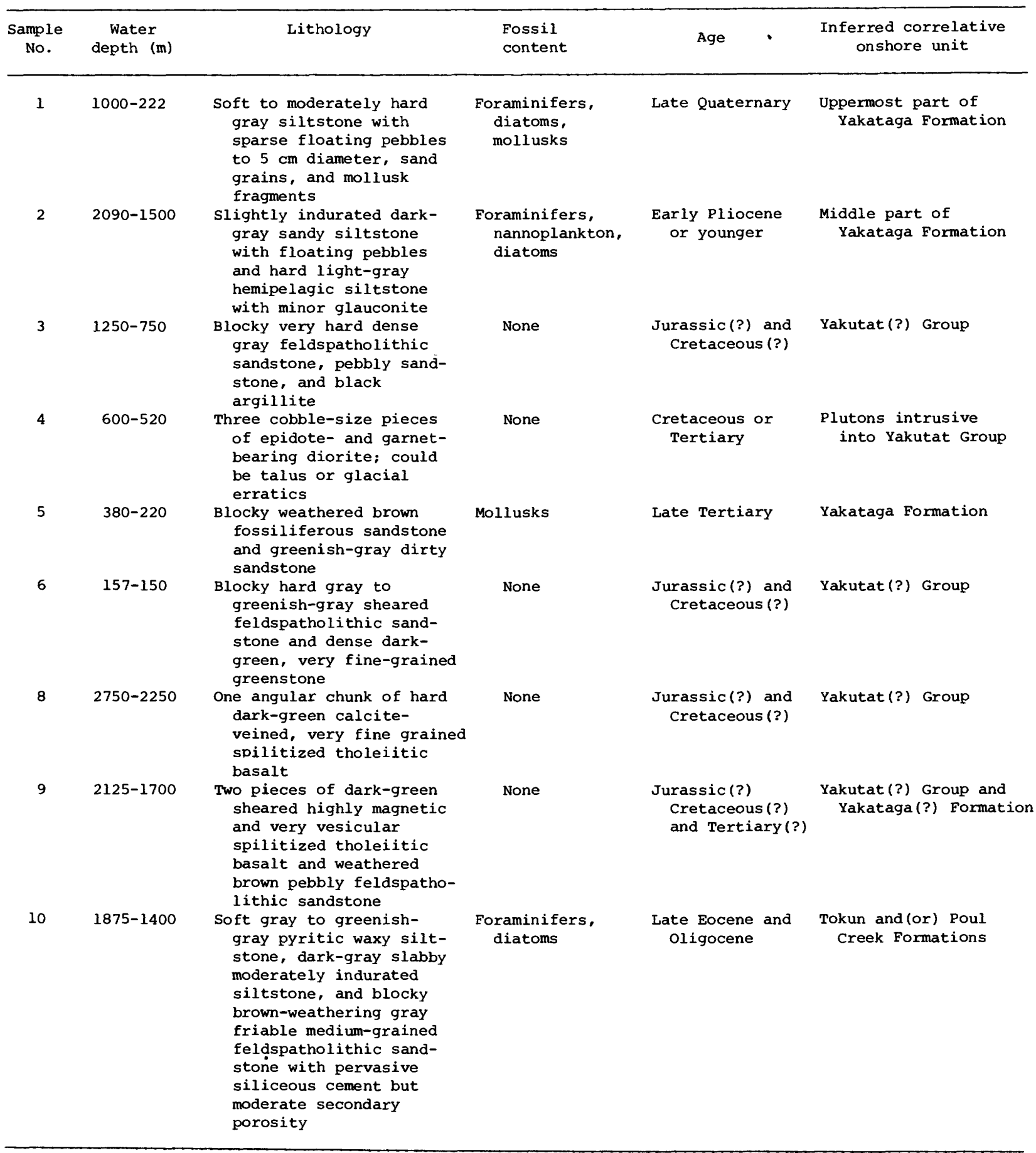


TABLE 5. - Summary of data for outcrop samples recovered in dredge hauls, eastern Gulf of Alaska-Continued

\begin{tabular}{|c|c|c|c|c|c|}
\hline $\begin{array}{l}\text { Sample } \\
\text { No. }\end{array}$ & $\begin{array}{c}\text { Water } \\
\text { depth (m) }\end{array}$ & Lithology & $\begin{array}{l}\text { Fossil } \\
\text { content }\end{array}$ & Age & $\begin{array}{l}\text { Inferred correlative } \\
\text { onshore unit }\end{array}$ \\
\hline 11 & $890-500$ & $\begin{array}{l}\text { Moderately well indurated } \\
\text { slabby dark-gray silt- } \\
\text { stone and foraminiferal } \\
\text { sandy siltstone with } \\
\text { hard brown-weathering } \\
\text { gray medium-grained } \\
\text { feldspatholithic sand- } \\
\text { stone with calcareous } \\
\text { cement }\end{array}$ & $\begin{array}{c}\text { Foraminifers, } \\
\text { coccoliths }\end{array}$ & Late Eocene & Tokun Formation \\
\hline 17 & $1025-925$ & $\begin{array}{l}\text { Black laminated shale } \\
\text { with partings of fine- } \\
\text { grained highly mica- } \\
\text { ceous sandstone and } \\
\text { soft medium-gray silt- } \\
\text { stone. Subordinate } \\
\text { gray friable medium- } \\
\text { grained feldspatholithic } \\
\text { sandstone with pervasive } \\
\text { siliceous cement and } \\
\text { moderate secondary poros- } \\
\text { ity }\end{array}$ & $\begin{array}{l}\text { Diatoms, sili- } \\
\text { coglagellates, } \\
\text { foraminifers }\end{array}$ & Late oligocene & $\begin{array}{l}\text { Upper part of Poul } \\
\text { Creek Formation }\end{array}$ \\
\hline 18 & $510-250$ & $\begin{array}{l}\text { Gray siltstone with abun- } \\
\text { dant microfauna and } \\
\text { sparse glauconite and } \\
\text { pyritic micronodules. } \\
\text { Cut by closely spaced, } \\
\text { slickensided fractures }\end{array}$ & $\begin{array}{l}\text { Diatoms, sili- } \\
\text { coflagellates }\end{array}$ & Late oligocene & $\begin{array}{l}\text { Upper part of Poul } \\
\text { Creek Formation }\end{array}$ \\
\hline 19 & $2230-1350$ & $\begin{array}{l}\text { Sticky olive-green chlo- } \\
\text { ritic mud on dredge jaws } \\
\text { that is probably scraped } \\
\text { from weathered greenstone }\end{array}$ & None & $\begin{array}{l}\text { Jurassic(?) and } \\
\text { Cretaceous (?) }\end{array}$ & Yakutat(?) Group \\
\hline 36 & $3500-2650$ & $\begin{array}{l}\text { Two chunks of dense, } \\
\text { olive-gray siliceous } \\
\text { siltstone with rare } \\
\text { floating sand grains } \\
\text { and pebbles as large } \\
\text { as } 1 \mathrm{~cm}\end{array}$ & $\begin{array}{l}\text { Diatoms, sponge } \\
\text { spicules, } \\
\text { reworked } \\
\text { coccoliths }\end{array}$ & $\begin{array}{l}\text { Early } \\
\quad \text { Pleistocene }\end{array}$ & $\begin{array}{l}\text { Upper part of } \\
\text { Yakataga Formation }\end{array}$ \\
\hline
\end{tabular}




\section{REPORTS ON ALASKA PUBLISHED BY THE \\ U.S. GEOLOGICAL SURVEY IN 1977}

Albert, N. R. D., and Steele, W. C., 1976, Interpretation of Landsat imagery of the Tanacross quadrangle, Alaska: U.S. Geol. Survey Misc. Field Studies Map MF-767-C, 3 sheets, scale 1:250,000. 1977, Landsat data interpretation, McCarthy, Tanacross, and Talkeetna quadrangles, in Blean, K. M., ed., The United States Geological Survey in Alaska--Accomplishments during 1976: U.S. Geol. Survey Circ. 751-B, p. B58-B61.

Anderson, G. S., 1977, Artificial recharge experiments on the Ship Creek alluvial fan, Anchorage, Alaska: Natl. Tech. Inf. Service PB-270 623/AS, $50 \mathrm{p}$.

Armstrong, A. K., Harris, A. G., Reed, Bruce, and Carter, Claire, 1977, Paleozoic sedimentary rocks in the northwestern part of Talkeetna quadrangle, Alaska Range, Alaska, in Blean, K. M., ed., The United States Geological Survey in Alaska-Accomplishments during 1976: U.S. Geol. Survey Circ. 751-B, p. B61-B62.

Armstrong, A. K., and MacKevett, E. M., Jr., 1977a, Carbonate sedimentation, sabkha facies, diagenesis, and stratigraphy, lower part of the Chitistone Limestone - the Triassic host rock for Kennecott-type copper deposits, in Blean, K. M., ed., The United States Geological Survey in Alaska--Accomplishments during 1976: U.S. Geol. Survey Circ. 751-B, p. B56.

1977b, The Triassic Chitistone Limestone, Wrangell Mountains, Alaska -- stressing detailed descriptions of sabkha facies and other rocks in lower parts of the Chitistone and their relations to Kennecott-type copper deposits: U.S. Geol. Survey Open-file Rept. 77-217, 63 p.

Armstrong, A. K., and Mamet, B. L., 1977a, Carboniferous microfacies, microfossils, and corals, Lisburne Group, arctic Alaska, in Blean, K. M., ed., The United States Geological Survey in Alaska--Accompli shments during 1976: U.S. Geol. Survey Circ. 751-B, p. B18.

1977b, Mississippian microfacies of the Lisburne Group, Endicott Mountains, arctic Alaska, in Blean, K. M., ed., The United States Geological Survey in Alaska--Accomplishments during 1976: U.S. Geol. Survey Circ. 751-B, p. B18-B19.

Barnes, D. F., 1977a, Bouguer gravity map of Alaska: U.S. Geol. Survey Geophys. Inv. Map GP-913, 1 sheet, scale 1:2,500,000.

1977b, Preliminary Bouguer gravity map of central Alaska: U.S. Geol. Survey Open-file Rept. 77-168-C, 1 sheet, scale 1:1,000,000.

$1977 \mathrm{c}$, Gravity map of the eastern part of southern Alaska: U.S. Geol. Survey Open-file Rept. 77-169-C, 1 sheet, scale 1:1,000,000.

Barnes, D. F., and Watts, R. D., 1977, Geophysical surveys in Glacier Bay National Monument, in Blean, K. M., ed., The United States Geological Survey in Alaska--Accomplishments during 1976: U.S. Geol. Survey Circ. 751-B, p. B93-B95.

Barnes, Peter, Reimnitz, Erk, Drake, D. E., and Toimil, L. J., 1977, Miscellaneous hydrologic and geologic observations on the inner Beaufort Sea shelf, Alaska: U.S. Geol. Survey Open-file Rept. $77-477,95$ p.

Barnes, Peter, Reimnitz, Erk, Smith, Greg, and Melchior, John, 1977, Bathymetric and shoreline changes, northwestern Prudhoe Bay, Alaska: U.S. Geol. Survey Open-file Rept. 77-161, 15 p.
Bartsch-Winkler, Susan, 1977a, Geologic mapping in Alaska; U.S. Geological Survey, post-1930, scales $1: 96,000$ to $1: 250,000:$ U.S. Geol. Survey Open-file Rept. 77-681, 1 sheet.

1977b, Geologic mapping in Alaska; U.S. Geological Survey, post-1930, scales 1:20,000 to 1:63,360: U.S. Geol. Survey Open-file Rept. $77-682,1$ sheet.

Bayer, K. C., Mattick, R. E., Plafker, George, and Bruns, T. R., 1977, Refraction studies between Icy Bay and Kayak Island, eastern Gulf of Alaska: U.S. Geol. Survey Open-file Rept. 77-550, 29 p.

Beikman, H. M., 1977, Preliminary geologic map of Alaska, in Blean, K. M., ed., The United States Geological Survey in Alaska--Accomplishments during 1976: U.S. Geol. Survey Circ. 751-B, p. B1, B4.

Beikman, H. M., Holloway, C. D., and Mackevett, E. M., Jr., 1977, Generalized geologic map of the eastern part of southern Alaska; U.S. Geol. Survey Open-file Rept. 77-169-B, 1 sheet, scale $1: 1,000,000$.

Berg, H. C., Elliott, R. L., Smith, J. G., Pittman, T. L., and Kimball, A. L., 1977, Mineral resources of the Granite Fiords wilderness study area, Alaska, with a section on aeromagnetic data by Andrew Griscom: U.S. Geol. Survey Bull. 1403, 151 p.

Berg, H. C., Smith, J. G., Elliott, R. L., and Koch, R. D., 1977, Structural elements of Insular Belt and Coast Range plutonic complex near Ketchikan, Alaska; a progress report, in Blean, K. M., ed., The United States Geological Survey in

Alaska-Accomplishments during 1976: U.S. Geol. Survey Circ. 751-B, p. B76-B78.

Biddle, K. T., 1977, Preliminary study of heavy minerals from the Beluga and Sterling Formations exposed near Homer, Kenai Peninsula, Alaska: U.S. Geol. Survey Open-file Rept. 77-874, 12 p.

Bird, K. J., 1977, Late Paleozoic carbonates from the south-central Brooks Range, in Blean, K. M., ed., The United States Geological Survey in Alaska-Accomplishments during 1976: U.S. Geol. Survey Circ. 751-B, p. B19-B20.

Blackford, Michael, 1977, Seismicity patterns in the Cook Inlet-Prince William Sound region, Alaska, in Blean, K. M., ed., The United States Geological Survey in Alaska--Accompli shments during 1976: U.S. Geol. Survey Circ. 751-B, p. B94-B96.

Blean, K. M., ed., 1977a, The United States Geological Survey in Alaska; organization and status of programs in 1977: U.S. Geol. Survey Circ. 751-A, p. A1-A66. 1977b, The United States Geological Survey in Alaska--Accomplishments during 1976: U.S. Geol. Survey Circ. 751-B, p. B1-B112.

Boucher, Gary, 1977, Gravity measurements on summer sea ice in the Beaufort and Chukchi Seas, 1976: U.S. Geol. Survey Open-file Rept. 77-705, 7 p.

Boucher, Gary, Ruppel, B. D., Chiburis, E. F., and Dehlinger, Peter, 1977, Map showing free-air gravity anomalies in the southern Beaufort Sea: U.S. Geol. Survey Misc. Field Studies Map MF-851, 1 sheet, scale approx. 1:1,000,000.

Brabb, E. E., and Hamachi, B. R., 1977, Chemical composition of Precambrian, Paleozoic, Mesozoic, and Tertiary rocks from east-central Alaska: U.S. Geol. Survey Open-file Rept. 77-631, 166 p.

Brew, D. A., and Ford, A. B., 1977a, Coast Range megalineament and Clarence Strait lineament on west edge of Coast Range batholithic complex, southeastern Alaska, in Blean, K. M., ed., The United States Geological Survey in Alaska--Accompli shments during 1976: U.S. Geol. 
Survey Circ. 751-B, p. B79.

$1977 b$, Preliminary geologic and

metamorphic-isograd map of the Juneau B-1

quadrangle, Alaska; U.S. Geol. Survey Misc. Field Studies Map MF-846, 1 sheet, scale 1:31,680.

Brew, D. A., Grybeck, Donald, Johnson, B. R., Jachens, R. C., Nutt, C. J., Barnes, D. F., Kimball, A. L., Still, J. C., and Rataj, J. L., 1977, Mineral resources of the Tracy Arm-Fords Terror wilderness study area and vicinity, Alaska: U.S. Geol. Survey Open-file Rept. 77-649, 282 p.

Brew, D. A., Johnson, B. R., Nutt, C. J., Grybeck, Donald, and Ford, A. B., 1977, Newly discovered granitic and gabbroic bodies in the Fairweather Range, Glacier Bay National Monument, Alaska, in Blean, K. M., ed., The United States Geological Survey in Alaska--Accomplishments during 1976: U.S. Geol. Survey Circ. 751-B, p. B90-B91.

Brew, D. A., Loney, R. A., Kistler, R. W. , Czamanske, G. K., Gromme, C. S., and Tatsumoto, Mitsunobu, 1977, Probable Precambrian or lower Paleozoic rocks in the Fairweather Range, Glacier Bay National Monument, Alaska, in Blean, K. M., ed., The United States Geological Survey in Alaska--Accomplishments during 1976: U.S. Geol. Survey Circ. 751-B, p. B91-B93.

Brooks, R. A., and Finch, W. I., 1977, Carborne radiometric survey of the Nome area, Seward Peninsula, Alaska: U.S. Geol. Survey Open-file Rept. 77-472, 22 p.

Brosge, W. P., and Armstrong, A. K., 1977, Lithologic logs of Lisburne Group in Lawrence Livermore Laboratory Drill Holes 1 and 2, Confusion Creek, Chandler Lake quadrangle, northern Alaska: U.S. Geol. Survey Open-file Rept. 77-26, 12 p.

Brosge, W. P., and Pessel, G. H., 1977, Preliminary reconnaissance geologic map of Survey Pass quadrangle, Alaska: U.S. Geol. Survey Open-file Rept. 77-27, 1 sheet, scale 1:250,000.

Brosge, W. P., and Reiser, H. N., 1977a, Lead-zinc mineralization at Bear Mountain, southeastern Brooks Range, in Blean, K. M., ed., The United States Geological Survey in

Alaska--Accomplishments during 1976: U.S. Geol. Survey Circ. 751-B, p. B8-B10.

$1977 \mathrm{~b}$, Chemical analyses of stream-sediment samples from the Table Mountain and Arctic quadrangles, northern Alaska: U.S. Geol. Survey Open-file Rept. 77-29, 5 sheets.

Brosge, W. P., Reiser, H. N., Dutro, J. T., Jr., and Detterman, R. L., 1977, Generalized geologic map of the Philip Smith Mountains quadrangle, Alaska: U.S. Geol. Survey Open-file Rept. $77-430,1$ sheet, scale 1:200,000.

Brosge, W. P., Reiser, H. N., and Moore, T. E., 1977 , Chemical analyses of 97 stream-sediment samples from the Coleen and Christian quadrangles, northern Alaska: U.S. Geol. Survey Open-file Rept. $77-458,4 \mathrm{p}$.

Bruns, T. R., and Bayer, Kenneth, 1977, Multichannel seismic reflection data acquired on the $M / V$ Cecil H. Green in the Gulf of Alaska, June-August 1975: U.S. Geol. Survey Open-file Rept. 77-352, 22 p.

Bruns, T. R., and von Huene, Roland, 1977, Sedimentary basins on the Shumagin shelf, western Gulf of Alaska, in Blean, K. M., ed., The United States Geological Survey in Alaska--Accomplishments during 1976: U.S. Geol. Survey Circ. 751-B, p. B97.

Bunker, C. M., Hedge, C. E., and Sainsbury, C. L., 1977, Radicelement concentrations and preliminary radiometric ages of rocks of the Kigluaik Mountains, Seward Peninsula, Alaska: U.S. Geol.
Survey Open-file Rept. 77-735, 36 p.

Carlson, P. R., Molnia, B. F., Bruns, T. R., and Whitney, J. W., 1977, Shelf-edge scarps in the northern Gulf of Alaska, in Blean, K. M., ed., The United States Geological Survey in

Alaska--Accomplishments during 1976: U.S. Geol. Survey Circ. 751-B, p. B96-B97.

Carlson, P. R., Molnia, B. F., Kittleson, S. C., and Hampson, J. C., Jr., 1977, Map of distribution of bottom sediments on the continental shelf, northern Gulf of Alaska: U.S. Geol. Survey Misc. Field Studies Map MF-876, 2 sheets, various scales.

Carter, L. D., Repenning, C. A., Marincovich, L. N., Hazel, J. E., Hopkins, D. M., McDougall, Kristin, and Naeser, C. W., 1977, Gubik and pre-Gubik Cenozoic deposits along the Colville River near Ocean Point, North Slope, Alaska, in Blean, K. M., ed., The United States Geological Survey in Alaska--Accomplishments during 1976: U.S. Geol. Survey Circ. 751-B, p. B12-B14.

Carter, R. D., Mull, C. G., and Bird, K. J., 1977, Any Prudhoe Bays in Naval Petroleum Reserve No. 4?, in Blean, K. M., ed., The United States Geological Survey in Alaska--Accomplishments during 1976: U.S. Geol. Survey Circ. 751-B, p. B14-B15.

Carter, R. D., Mull, C. G., Bird, K. J., and Powers, R. B., 1977, The petroleum geology and hydrocarbon potential of Naval Petroleum Reserve No. 4, North Slope, Alaska: U.S. Geol. Survey Open-file Rept. $77-475,61 \mathrm{p}$.

Cathrall, J. B., Cooley, E. F., Detra, D. E., and Billings, T. M., 1977, A listing and statistical summary of spectrographic analyses of heavy mineral concentrate samples for the Philip Smith Mountains quadrangle, Alaska: U.S. Geol. Survey Open-file Rept. 77-426, 70 p.

Cathrall, J. B., Cooley, E. F., Detra, D. E., and O'Leary, R. M., 1977, A listing and statistical summary of spectrographic and chemical analyses of stream-sediments and rock samples from the Philip Smith Mountains quadrangle, Alaska: U.S. Geol. Survey Open-file Rept. 77-244, 79 p.

Chapman, R. M., 1977, Geochemical anomalies in bedrock, west half of Kantishna River quadrangle, in Blean, K. M., ed., The United States Geological Survey in Alaska--Accomplishments during 1976: U.S. Geol. Survey Circ. 751-B, p. B35-B36.

Childers, J. M., Sloan, C. E., Meckel, J. P., and Nauman, J. W., 1977, Hydrologic reconnaissance of the eastern North Slope, Alaska, 1975: U.S. Geol. Survey Open-file Rept. 77-492, 65 p.

Churkin, Michael, Jr., Carter, Claire, and Johnson, B. R., 1977, A new Ordovician time scale based on accumulation rates of graptolite shale, in Blean, K. M., ed., The United States Geological Survey in Alaska; accomplishemts during 1976: U.S. Geol. Survey Circ. 751-B, p. B4-B6.

Churkin, Michael, Jr., and Eberlein, G. D., 1977 , Correlation of the rocks of southeastern Alaska with other parts of the Cordillera, in Blean, $\mathrm{K}$. M., ed., The United States Geological Survey in Alaska--Accomplishments during 1976: U.S. Geol. Survey Circ. 751-B, p. B69-B72.

Churkin, Michael, Jr., Reed, B. L., Carter, Claire, and Winkler, G. R., 1977, Lower Paleozoic graptolitic section in the Terra Cotta Mountains, southern Alaska Range, in Blean, K. M., ed., The United States Geological Survey in Alaska--Accomplishments during 1976: U.S. Geol. Survey Circ. 751-B, p. B37-B38.

Cobb, E. H., 1977a, Mineral resources of Alaska, in Blean, K. M., ed., The United States Geological 
Survey in Alaska--Accomplishments during 1976: U.S. Geol. Survey Circ. 751-B, p. B1.

1977b, Placer deposits map of central Alaska: U.S. Geol. Survey Open-file Rept. 77-168-B, 64 p. and 1 map, scale 1:1,000,000.

1977c, Selected Geological Survey, U.S. Bureau of Mines, and Alaska Division of Geological and Geophysical Surveys reports and maps on Alaska released during 1976, indexed by quadrangle: U.S. Geol. Survey Open-file Rept. 77-177, 115 p.

1977 , Summary of references to mineral occurrences (other than mineral fuels and construction materials) in the Tanana quadrangle, Alaska: U.S. Geol. Survey Open-file Rept. 77-432, $110 \mathrm{p}$.

1977 , Summary of references to mineral occurrences (other than mineral fuels and construction materials) in the Eagle quadrangle, Alaska: U.S. Geol. Survey Open-file Rept. 77-845, $122 \mathrm{p}$.

Cobb, E. H., Dusel-Bacon, Cynthia, MacKevett, E. M., Jr., and Berg, H. C., 1977, Map showing distribution of mineral deposits (other than organic fuels and construction materials) in Alaska: U.S. Geol. Survey Open-file Rept. 77-496, $45 \mathrm{p}$. and 1 map, scale 1:2,500,000.

Cof fman, J. L., and Stover, C. W., eds., 1976, United States earthquakes, 1974: Natl. Tech. Inf. Service PB-260 697/AS, $125 \mathrm{p}$.

Coffman, J. L., von Hake, C. A., Spence, William, Carver, D. L., and Covington, P. A., eds., 1976, United States earthquakes, 1973,: Natl. Tech. Inf. Service PB-250 362/AS, 118 p.

Cohee, G. V., and Wright, W. B., 1976, Changes in stratigraphic nomenclature by the U.S. Geological Survey, 1975: U.S. Geol. Survey Bull. 1422-A, p. A1-A84.

Connelly, William, and Moore, J. C., 1977, Geologic map of the northwest side of the Kodiak Islands, Alaska: U.S. Geol. Survey Open-file Rept. 77-382, 2 sheets, scales $1: 250,000$ and 1:63,360.

Cooper, A. K., 1977, Marine geophysical investigation in the Bering Sea basin, in Blean, K. M., ed., The United States Geological Survey in Alaska--Accomplishments during 1976: U.S. Geol. Survey Circ. 751-B, p. B98-B100.

Csejtey, Bela, Jr., Nelson, W. H., Eberlein, G. D., Lanphere, M. A., and Smith, J. G., 1977, New data concerning age of the Arkose Ridge Formation, south-central Alaska, in Blean, K. M., ed., The United States Geological Survey in

Alaska--Accomplishments during 1976: U.S. Geol. Survey Circ. 751-B, p. B62-B64.

Dearborn, L. L., 1977, Ground-water investigation at the alluvial fan of the South Fork Eagle River, Anchorage, Alaska - Results of test drilling, 1976: U.S. Geol. Survey Open-file Rept. 77-493, 9 p.

Detra, D. E., 1977, Delineation of an anomalous lead-zinc area in the Philip Smith Mountains A-2 quadrangle, Alaska: U.S. Geol. Survey Open-file Rept. 77-223, $11 \mathrm{p}$.

Detra, D. E., Smith, S. C., Risoli, D. A., and Day, G. W., 1977, Spectrographic analyses of heavy-mineral concentrate samples and chemical analyses of organic samples from the Chandalar quadrangle Alaska: U.S. Geol. Survey Open-file Rept. 77-543, $151 \mathrm{p}$.

Detterman, R. L., and Dutro, J. T., Jr., 1977, Depositional environment and fauna for a section of the Sadlerochit Group, northeastern Alaska, in Blean, K. M., ed., The United States Geological Survey in Alaska--Accomplishments during 1976:
U.S. Geol. Survey Circ. 751-B, p. B10-B12.

Dickinson, K. A., 1977, Uranium and thorium

distribution in continental Tertiary rocks of the Cook Inlet basin and some adjacent areas, Alaska, in Campbell, J. A., ed., Short papers of the U.S. Geological Survey uranium-thorium symposium, 1977: U.S. Geol. Survey Circ. 753, p. 70-72.

Doyle, P. F., 1977, Streamflow and channel erosion along the TAPS route, in Blean, K. M., ed., The United States Geological Survey in

Alaska--Accompli shments during 1976: U.S. Geol. Survey Circ. 751-B, p. B7.

Doyle, P. F., and Childers, J. M., 1977, Channel erosion surveys along TAPS route, Alaska, 1976: U.S. Geol. Survey Open-file Rept. 77-170, 93 p.

Dutro, J. T., Jr., Brosge, W. P., and Reiser, H. N., 1977, Upper Devonian depositional history, central Brooks Range, Alaska, in Blean, K. M., ed., The United States Geological Survey in

Alaska--Accomplishments during 1976: U.S. Geol. Survey Circ. 751-B, p. B16-B18.

Eberlein, G. D., Gassaway, J. S., and Beikman, H. M., 1977, Preliminary geologic map of central Alaska: U.S. Geol. Survey Open-file Rept. 77-168-A, 1 sheet, scale 1:1,000,000.

Eittreim, Stephen, Grantz, Arthur, and Whitney, O. T., 1977, Tectonic imprints on sedimentary deposits in the Hope basin, in Blean, K. M., ed., The United States Geological Survey in

Alaska--Accomplishments during 1976: U.S. Geol. Survey Circ. 751-B, p. B100-B103.

Feulner, A. J., and Reed, K. M., 1977, Bibliography of reports by members of the U.S. Geological Survey on the water resources of Alaska, 1870 through 1976: U.S. Geol. Survey Open-file Rept. 77-687, $112 \mathrm{p}$.

Finch, W. I., 1977, United States Geological Survey uranium and thorium resource assessment and exploration research program, fiscal year 1977: U.S. Geol. Survey Open-file Rept. 77-218, 27 p.

Fisher, M. A., and Magoon, L. B., 1977, Geologic framework of lower Cook Inlet, Alaska: U.S. Geol. Survey Open-file Rept. 77-136, 73 p.

Ford, A. B., and Brew, D. A., 1977a, Truncation of regional metamorphic zonation pattern of the Juneau, Alaska, area by the Coast Range batholith, in Blean, K. M., ed., The United States Geological Survey in Alaska--Accomplishments during 1976: U.S. Geol. Survey Circ. 751-B, p. B85-B87.

$1977 \mathrm{~b}$, Chemical nature of Cretaceous greenstone near Juneau, Alaska, in Blean, K. M., ed., The United States Geological Survey in Alaska--Accomplishments during 1976: U.S. Geol. Survey Circ. 751-B, p. B88-B90.

1977c, Preliminary geologic and metamorphic-isograd map of northern parts of the Juneau A-1 and A-2 quadrangles, Alaska: U.S. Geol. Survey Misc. Field Studies Map MF-847, 1 sheet, scale $1: 31,680$.

Foster, H. L., Dusel-Bacon, Cynthia, and Weber, F. R., 1977, Reconnaissance geologic map of the Big Delta C-4 quadrangle, Alaska: U.S. Geol. Survey Open-file Rept. 77-262, 1 sheet, scale 1:63,360.

Foster, H. L., Weber, F. R., and Dusel-Bacon, Cynthia, 1977, Gneiss dome in the Big Delta C-4 quadrangle, Alaska, in Blean, K. M., ed., The United States Geological Survey in Alaska--Accomplishments during 1976: U.S. Geol. Survey Circ. 751-B, p. B33.

Gardner, J. V., and Vallier, T. L., 1977, Underway geophysical data collected on U.S.G.S. cruise 54-76, southern Beringian shelf: U.S. Geol. Survey Open-file Rept. 77-524, 5 p. 
Grybeck, Donald, 1977a, Known mineral deposits of the Brooks Range, Alaska: U.S. Geol. Survey Open-file Rept. $77-166-\mathrm{C}, 45 \mathrm{p}$. and 1 map, scale $1: 1,000,000$.

$1977 \mathrm{~b}$, Map showing geochemical anomalies in the Brooks Range, Alaska: U.S. Geol. Survey Open-file Rept. 77-166-D, 1 sheet, scale 1:1,000,000.

Grybeck, Donald, Beikman, H. M., Brosge, W. P., Tailleur, I. L., and Mull, C. G., 1977, Geologic map of the Brooks Range, Alaska: U. S. Geol. Survey Open-file Rept. 77-166-B, 2 sheets, scale $1: 1,000,000$.

Grybeck, Donald, Brew, D. A., Johnson, B. R., and Nutt, C. J., 1977, Ultramafic rocks in part of the Coast Range batholithic complex, southeastern Alaska, in Blean, K. M., ed., The United States Geological Survey in Alaska--Accomplishments during 1976: U.S. Geol. Survey Circ. 751-B, p. B82-B85.

Hamilton, T. D., 1977, Surficial geology of the east-central Brooks Range, in Blean, K. M., ed., The United States Geological Survey in Alaska--Accomplishments during 1976: U.S. Geol. Survey Circ. 751-B, p. B15-B16.

Hampton, M. A., and Bouma, A. H., 1977, Seismic reflection records showing stable and unstable slopes near the shelf break, western Gulf of Alaska: U.S. Geol. Survey Open-file Rept. 77-702, 30 p. (unnumbered).

Hardin, Deborah, Barnes, Peter, and Reimnitz, Erk, 1977, Distribution and character of naleds in northeastern Alaska: U.S. Geol. Survey Open-file Rept. 77-91, 28 p.

Hein, J. R., Bouma, A. H., and Hampton, M. A., 1977, Distribution of clay minerals in lower Cook Inlet and Kodiak shelf sediment, Alaska: U.S. Geol. Survey Open-file Rept. 77-581, $17 \mathrm{p}$.

Hoare, J. M., and Cobb, E. H., 1977, Mineral occurrences (other than mineral fuels and construction materials) in the Bethel, Goodnews, and Russian Mission quadrangles, Alaska: U.S. Geol. Survey Open-file Rept. 77-156, 98 p.

Hoare, J. M., and Coonrad, W. L., 1977, Blue amphibole occurrences in southwestern Alaska, in Blean, $\mathrm{K}$. M., ed., The United States Geological Survey in Alaska--Accomplishments during 1976: U.S. Geol. Survey Circ. 751-B, p. B39.

Hopkins, D. M., 1977, Coastal processes and coastal erosion hazards to the Cape Krusenstern archaeological site: U.S. Geol. Survey Open-file Rept. 77-32, $17 \mathrm{p}$.

Hudson, Travis, 1977a, Genesis of a zoned granitic stock, Seward Peninsula, Alaska: U.S. Geol. Survey Open-file Rept. 77-35, $188 \mathrm{p}$.

$1977 b$, Preliminary geologic map of Seward Peninsula, Alaska: U.S. Geol. Survey Open-file Rept. 77-167-A, 1 sheet, scale 1:1,000,000. 1977 c, Map showing preliminary framework data for evaluation of the metallic mineral resource potential of northern Seward Peninsula, Alaska: U.S. Geol. Survey Open-file Rept. 77-167-B, 1 sheet, scale 1:1,000,000.

Hudson, Travis, Elliott, R. L., and Smith, J. G., 1977, Investigations of the Wilson Arm molybdenite deposit, in Blean, K. M., ed., The United States Geological Survey in Alaska--Accomplishments during 1976: U.S. Geol. Survey Circ. 751-B, p. B74.

Hudson, Travis, Foster, H. L., and Weber, F. R., 1977, The Shaw Creek fault, east-central Alaska, in Blean, K. M., ed., The United States Geological Survey in Alaska--Accomplishments during 1976: U.S. Geol. Survey Circ. 751-B, p. B33-B34.
Hudson, Travis, Plafker, George, and Lanphere, M. A., 1977, Intrusive rocks of the Yakutat-St. Elias area, south-central Alaska: U.S. Geol. Survey Jour. Research, v. 5, no. 2, p. 155-172.

Hudson, Travis, Plafker, George, and Turner, D. L., 1977, Metamorphic rocks of the Yakutat-St. Elias area, south-central Alaska: U.S. Geol. Survey Jour. Research, v. 5, no. 2, p. 177-184.

Hudson, Travis, and Weber, F. R., 1977, The Donnelly Dome and Granite Mountain faults, south-central Alaska, in Blean, K. M., ed., The United States Geological Survey in Alaska--Accomplishments during 1976: U.S. Geol. Survey Circ. 751-B, p. B64-B66.

Johnson, B. R., Forn, C. L., Hoffman, J. D., Brew, D. A., and Nutt, C. J., 1977, Geochemical sampling of stream sediments, Tracy Arm, southeastern Alaska, in Blean, K. M., ed., The United States Geological Survey in Alaska--Accomplishments during 1976: U.S. Geol. Survey Circ. 751-B, p. B80-B82.

Kachadoorian, Reuben, Ovenshine, A. T., and Bartsch-Winkler, Susan, 1977, Late Wisconsin history of the south shore of Turnagain Arm, Alaska, in Blean, K. M., ed., The United States Geological Survey in Alaska--Accomplishments during 1976: U.S. Geol. Survey Circ. 751-B, p. B49-B50.

Karlson, R. C., Curtin, G. C., Cooley, E. F., and Garmezy, L., 1977, Geochemical maps of selected elements and results of spectrographic analyses for heavy-mineral concentrates from the western half of the Talkeetna Mountains quadrangle, Alaska: U.S. Geol. Survey Open-file Rept. 77-530, 32 p. and 5 maps, scale 1:250,000.

Keith, T. E. C., and Foster, H. L., 1977, Ultramafic rocks near Volkmar Lake, Big Delta quadrangle, Yukon-Tanana Upland, Alaska, in Blean, K. M., ed., The United States Geological Survey in Alaska--Accomplishments during 1976: U.S. Geol. Survey Circ. 751-B, p. B32-B33.

Kelley, J. S., 1977, Study of heavy minerals from Tertiary rocks at Capps Glacier and adjacent areas, southern Alaska: U.S. Geol. Survey Open-file Rept. 77-502, 11 p.

Koch, R. D., Elliott, R. L., Smith, J. G., and Berg, H. C., 1977, Metamorphosed trondhjemi te of the Alexander terrane in Coast Range plutonic complex, in Blean, K. M., ed., The United States Geological Survey in Alaska-Accomplishments during 1976: U.S. Geol. Survey Circ. 751-B, p. B72-B74.

Koch, R. D., Smith, J. G., and Elliott, R. L., 1977, Miocene or younger strike-slip(?) fault at Canoe Passage, southeastern Alaska, in Blean, K. M., ed., The United States Geological Survey in Alaska--Accomplishments during 1976: U.S. Geol. Survey Circ. 751-B, p. B76.

Kososki, B. A., and Anderson, R. C., 1977, Digital processing of a 24 channel, single-fold seismic reflection line from Naval Petroleum Reserve No. 4, Alaska: U.S. Geol. Survey Open-file Rept. 77-707, 7 p.

Lachenbruch, A. H., and Marshall, B. V., 1977, Sub-sea temperatures and a simple tentative model for offshore permafrost at Prudhoe Bay, Alaska: U.S. Geol. Survey Open-file Rept. 77-395, 54 p.

Lanphere, M. A., Churkin, Michael, Jr., and Eberlein, G. D., 1977, A new radiometric date for the Ordovician-Silurian boundary, in Blean, K. M., ed., The United States Geological Survey in Alaska--Accomplishments during 1976: U.S. Geol. Survey Circ. 751-B, p. B4-B5.

MacKevett, E. M., Jr., Albert, N. R. D., Barnes, D. F., Case, J.E., Robinson, Keith, and Singer, D. 
A., 1977, The Alaska Mineral Resource Assessment Program; Background information to accompany folio of geologic and mineral resource maps of the McCarthy quadrangle, Alaska: U.S. Geol. Survey Circ. 739,23 p.

MacKevett, E. M., Jr., and Holloway, C. D., 1977, Map showing metalliferous and selected nonmetalliferous mineral deposits in the eastern part of southern Alaska: U.S. Geol. Survey Open-file Rept. 77-169-A, 1 sheet and 99 p. tabular material, scale $1: 1,000,000$.

Mann, D. M., 1977, Shelled benthic fauna of the eastern Chukchi Sea: U.S. Geol. Survey Open-file Rept. 77-672, $112 \mathrm{p}$.

Marlow, M. S., 1977, Resource assessment and geophysical exploration of the southern Bering Sea shelf, in Blean, K. M., ed., The United States Geological Survey in Alaska--Accomplishments during 1976: U.S. Geol. Survey Circ. 751-B, p. B97-B98.

Mayo, L. R., 1977, Glacier research, in Blean, K. M., ed., The United States Geological Survey in Alaska--Accomplishments during 1976: U.S. Geol. Survey Circ. 751-B, p. B5-B6.

Mayo, L. R., Zenone, Chester, and Trabant, D. C., 1977, Reconnaissance hydrology of Portage Glacier basin, Alaska - 1972: U.S. Geol. Survey Hydrol. Inv. Atlas HA-583, 2 sheets, scale 1:50,000.

McCoy, G. A., 1977, Fisheries enhancement studies; limnological studies in southeastern Alaska and water quality measurements along the TAPS route during pipeline construction, in Blean, K. M., ed., The United States Geological Survey in Alaska--Accomplishments during 1976: U.S. Geol. Survey Circ. 751-B, p. B7-B8.

$1977 \mathrm{~b}$, A reconnaissance investigation of a large meromictic lake in southeastern Alaska: U.S. Geol. Survey Jour. Research, v. 5, no. 3, p. 319-324.

McCoy, G. A., Wiggins, W. W., and Schmidt, A. E., 1977, Limnological investigation of six lakes in southeast Alaska: U.S. Geol. Survey Water Resources Inv. Rept. WRI-76-122, 1 sheet.

McLean, Hugh, 1977, Organic geochemistry, lithology, and paleontology of Tertiary and Mesozoic rocks from wells on the Alaska Peninsula: U.S. Geol. Survey Open-file Rept. 77-813, 63 p.

McManus, D. A., Kolla, Venkatarathnam, Hopkins, D. M., and Nelson, C. H., 1977, Distribution of bottom sediments on the continental shelf, northern Bering Sea: U.S. Geol. Survey Prof. Paper 759-C, p. $\mathrm{C} 1-\mathrm{C} 31$.

Miller, R. J., Curtin, G. C., Hopkins, R. T., Jr., and Csejtey, Bela, Jr., 1977, Spectrographic and chemical analyses of stream-sediment and rock samples from the western part of the Talkeetna Mountains quadrangle, Alaska: U.S. Geol. Survey Open-file Rept. 77-471, 138 p.

Miller, T. P., 1977, Geologic interpretation of a radioactivity anomaly near the West Fork of the Buckland River, western Alaska: U.S. Geol. Survey Open-file Rept. 77-372, 9 p.

Miller, T. P., and Elliott, R. L., 1977, Progress report on uranium investigations in the Zane Hills area, west-central Alaska: U.S. Geol. Survey Open-file Rept. 77-428, 12 p.

Minsch, J. H., Stover, C. W., Person, W. J., and Simon, R. B., 1977, Earthquakes in the United States, October-December 1975: U.S. Geol. Survey Circ. 749-D, p. D1-D27.

Molnia, B. F., 1977, Surface sedimentary units of the Gulf of Alaska continental shelf; Montague Island to Yakutat Bay: U.S. Geol. Survey Open-file Rept. 77-30, 21 p.
Mull, C. G., 1977, Apparent south vergent folding and possible nappes in Schwatka Mountains, in Blean, K. M., ed., The United States Geological Survey in Alaska--Accomplishments during 1976: U.S. Geol. Survey Circ. 751-B, p. B29-B31.

Mull, C. G., and Kososki, B. A., 1977, Hydrocarbon assessment of the Arctic National Wildlife Range, eastern Arctic Slope, Alaska, in Blean, K. M., ed., The United States Geological Survey in Alaska--Accomplishments during 1976: U.S. Geol. Survey Circ. 751-B, B20-B22.

Mull, C. G., and Tailleur, I. L., 1977, Sadlerochit(?) Group in the Schwatka Mountains, south-central Brooks Range, in Blean, K. M., ed., The United States Geological Survey in Alaska--Accomplishments during 1976: U.S. Geol. Survey Circ. 751-B, p. B27-B29.

Nauman, J. W., and Kernodle, D. R., 1977, Aquatic organisms from selected sites along the trans-Alaska pipeline corridor, September 1970 to September 1972: U.S. Geol. Survey Open-file Rept. $77-634,55 \mathrm{p}$.

Nauman, J. W., Sloan, C. E., and Kernodle, D. R., $1977 a$, Effects of fuel oil leaks on water quality in three streams along the trans-Alaska pipeline, in Blean, K. M., ed., The United States Geological Survey in Alaska: accomplishments during 1976: U.S. Geol. Survey Circ. 751-B, p. B7. $1977 \mathrm{~b}$, Stream relocation and benthic invertebrates in Canyon Slough near Valdez, in Blean, K. M., ed., The United States Geological Survey in Alaska: accomplishments during 1976: U.S. Geol. Survey Circ. 751-B, p. B46.

Nelson, G. L., 1977a, North Slope water resources studies, in Blean, K. M., ed., The United States Geological Survey in Alaska--Accomplishments during 1976: U.S. Geol. Survey Circ. 751-B, p. B31.

1977b, Geohydrology of the Fairbanks-North Star Borough, in Blean, K. M., ed., The United States Geological Survey in Alaska--Accomplishments during 1976: U.S. Geol. Survey Circ. 751-B, B36-B37.

Nelson, Hans, 1977, Ice gouging and other environmental geologic problems of northern Bering Sea, in Blean, K. M., ed., The United States Geological Survey in Alaska--Accomplishments during 1976: U.S. Geol. Survey Circ. 751-B, p. B98.

Ovenshine, A. T., Bartsch-Winkler, Susan, Rupert, Jeff, and Kachadoorian, Reuben, 1977, Preliminary studies of a 93-meter core at Portage, Alaska, in Blean, K. M., ed., The United States Geological Survey in Alaska--Accomplishments during 1976: U.S. Geol. Survey Circ. 751-B, p. B50-B51.

Page, N.J, Berg, H. C., and Haffty, Joseph, 1977, Platinum, palladium, and rhodium in volcanic and plutonic rocks from the Gravina-Nutzotin belt, Alaska: U.S. Geol. Survey Jour. Research, v. 5, no. 5 , p. $629-636$.

Palmer, I. F., and Lyle, W. M., 1977, Cooperative stratigraphic project in lower cook Inlet and Kodiak areas, U.S. Geological Survey and State of Alaska Division of Geological and Geophysical Surveys, in Blean, K. M., ed., The United States GeologicaI Survey in Alaska--Accomplishments during 1976: U.S. Geol. Survey Circ. 751-B, p. B45-B46.

Patton, W. W., Jr., 1977, Pre-Ordovician unconformity in central Alaska, in Blean, K. M., ed., The United States Geological Survey in Alaska--Accomplishments during 1976: U.S. Geol. Survey Circ. 751-B, p. B39. 
Patton, W. W., Jr., Dutro, J. T., Jr., and Chapman, R. M., 1977, Late Paleozoic and Mesozoic stratigraphy of the Nixon Fork area, Medfra quadrangle, Alaska, in Blean, K. M., ed., The United States Geological Survey in Alaska--Accomplishments during 1976: U.S. Geol. Survey Circ. 751-B, p. B38-B40.

Patton, W. W., Jr., Miller, T. P., Chapman, R. M., and Yeend, Warren, 1977, Geologic map of the Melozitna quadrangle, Alaska: U.S. Geol. Survey Open-file Rept. 77-147, 1 sheet, scale 1:250,000.

Person, W. J., Simon, R. B., and Stover, C. W., 1977, Earthquakes in the United States, April-June 1975: U.S. Geol. Survey Circ. 749-B, p. B1-B27.

Pessel, G. H., and Brosge, W. P., 1977, Preliminary reconnaissance geologic map of Ambler River quadrangle, Alaska: U.S. Geol. Survey Open-file Rept. 77-28, 1 sheet, scale 1:250,000.

Petty-Ray Geophysical Division, Geosource, Inc., 1977, Marine high resolution geophysical survey - lower Cook Inlet, Alaska: U.S. Geol. Survey Open-file Rept. 77-358, 166 p. and 22 illus., scale $1: 96,000$.

Pewe, T. L., Bell, J. W., Forbes, R. B., and Weber, F. R., 1975, Geologic map of the Fairbanks D-2 NW quadrangle, Alaska: U.S. Geol. Survey Misc. Inv. Series Map I-907, 1 sheet, scale 1:24,000. 1976, Geologic map of the Fairbanks D-2 SE quadrangle, Alaska: U.S. Geol. Survey Misc. Inv. Series Map I-942, 1 sheet, scale 1:24,000.

1977, Geologic map of the Fairbanks D-2 NE quadrangle, Alaska: U.S. Geol. Survey Misc. Inv. Series Map I-950, 1 sheet, scale 1:24,000.

Pewe, T. L., Bell, J. W., Williams, J. R., and Paige, R. A., 1976, Geologic map of the Fairbanks D-1 SW quadrangle, Alaska: U.S. Geol. Survey Misc. Inv. Series Map I-949, 1 sheet, scale 1:24,000.

Plafker, George, Hudson, Travis, and Richter, D. H., 1977, Preliminary observations on late Cenozoic displacements along the Totschunda and Denali fault systems, in Blean, K. M., ed., The United States Geological Survey in

Alaska--Accomplishments during 1976: U.S. Geol. Survey Circ. 751-B, p. B67-B69.

Plafker, George, Jones, D. L., and Pessagno, E. A., Jr., 1977, A Cretaceous accretionary flysch and melange terrane along the Gulf of Alaska margin, in Blean, K. M., ed., The United States Geological Survey in Alaska--Accomplishments during 1976: U.S. Geol. Survey Circ. 751-B, p. B41-B43.

Plafker, George, Richter, D. H., and Hudson, Travis, 1977, Reinterpretation of the origin of inferred Tertiary tillite in the northern Wrangell Mountains, Alaşka, in Blean, K. M., ed., The United States Geological Survey in

Alaska--Accomplishments during 1976: U.S. Geol. Survey Circ. 751-B, p. B52-B54.

Post, Austin, 1977, Reported observations of icebergs from Columbia Glacier in Valdez Arm and Columbia Bay, Alaska, during the summer of 1976: U.S. Geol. Survey Open-file Rept. 77-235, 7 p.

Rau, W. W. , Plafker, George, and Winkler, G. R., 1977, Preliminary foraminiferal biostratigraphy and correlation of selected stratigraphic sections and wells in the Gulf of Alaska Tertiary Province: U.S. Geol. Survey Open-file Rept. 77-747, 54 p.

Reimnitz, Erk, Maurer, Doug, Barnes, Peter, and Toimil, Larry, 1977, Some physical properties of shelf surface sediments, Beaufort Sea, Alaska: U.S. Geol. Survey Open-file Rept. 77-416, 23 p.

Richter, D. H., Sharp, W. N., Dutro, J. T., Jr., and Hamilton, W. B., 1977, Geologic map of parts of the Mount Hayes $\mathrm{A}-1$ and $\mathrm{A}-2$ quadrangles, Alaska: U.S. Geol. Survey Misc. Inv. Series Map I-1031, 1 sheet, scale $1: 63,360$.

Robinson, Keith, McDougal, C. M., Day, G. W., and Billings, Theodore, 1976a, Distribution and abundance of copper in stream sediments and moraine debris, McCarthy quadrangle, Alaska: U.S. Geo1. Survey Misc. Field Studies Map MF-773-F, 1 sheet, scale $1: 250,000$.

$1976 \mathrm{~b}$, Distribution and abundance of lead in stream sediments and moraine debris, McCarthy quadrangle, Alaska: U.S. Geol. Survey Misc. Field Studies Map MF-773-G, 1 sheet, scale 1:250,000.

$1976 \mathrm{c}$, Distribution and abundance of gold in stream sediments and moraine debris, McCarthy quadrangle, Alaska: U.S. Geol. Survey Misc. Field Studies Map MF-773-H, 1 sheet, scale 1:250,000.

Robinson, Keith, McDougal, C. M., McDanal, S. K., and Billings, Theodore, 1976a, Distribution and abundance of molybdenum in bedrock, 'mineralized, vein, and altered rock samples, McCarthy quadrangle, Alaska: U.S. Geol. Survey Misc. Field Studies Map MF-773-J, 1 sheet, scale 1:250,000.

$1976 \mathrm{~b}$, Distribution and abundance of silver in bedrock, mineralized, vein, and altered rock samples, McCarthy quadrangle, Alaska: U.S. Geol. Survey Misc. Field Studies Map MF-773-K, 1 sheet, scale $1: 250,000$.

1976c, Distribution and abundance of gold in bedrock, mineralized, vein, and altered rock samples, McCarthy quadrangle, Alaska: U.S. Geol. Survey Misc. Field Studies Map MF-773-L, 1 sheet, scale 1:250,000.

Robinson, Keith, McDougal, C. M., O'Leary, R. M., and Billings, Theodore, 1976, Distribution and abundance of arsenic in bedrock, mineralized, vein, and altered rock samples, McCarthy quadrangle, Alaska: U.S. Geol. Survey Misc. Field Studies Map MF-773-M, 1 sheet, scale 1:250,000.

Robinson, Keith, O'Leary, R. M., McDougal, C. M., and Billings, Theodore, 1976, Distribution and abundance of arsenic and mercury in stream sediments and moraine debris, McCarthy quadrangle, Alaska: U.S. Geol. Survey Misc. Field Studies Map MF-773-I, 1 sheet, scale 1:250,000.

Sable, E. G., 1977, Geology of the western Romanzof Mountains, Brooks Range, Alaska: U.S. Geol. Survey Prof. Paper 897, $84 \mathrm{p}$.

Savage, N. M., Eberlein, G. D., and Churkin, Michael, Jr., 1977, Early Devonian conodonts found with a classical Upper Silurian brachiopod fauna, southeastern Alaska, in Blean, K. M., ed., The United States Geological Survey in Alaska--Accomplishments during 1976: U.S. Geol. Survey Circ. 751-B, p. B79-B81.

Schmoll, H. R., 1977, Engineering geology of Anchorage Borough, in Blean, K. M., ed., The United States Geological Survey in Alaska--Accomplishments during 1976: U.S. Geol. Survey Circ. 751-B, p. B51-B52.

Silberman, M. L., Mathews, Alan, Potter, R. W., and Nissenbaum, Arie, 1977, Stable isotope geochemistry, sulfide mineralogy, and potassium-argon ages of the Kennecott massive sulfide deposits, Alaska, in Blean, K. M., ed., The United States Geological Survey in Alaska--Accomplishments during 1976: U.S. Geol. Survey Circ. 751-B, p. B56-B58.

Silberman, M. L., Morton, J. L., Cox, D. C., and Richter, D. H., 1977, Potassium-argon ages of disseminated copper and molybdenum mineralization of the Klein Creek and Nabesna plutons, eastern Alaska Range, in Blean, K. M., ed., The United States Geological Survey in Alaska--Accomplishments during 1976: U.S. Geol. 
Survey Circ. 751-B, p. B54-B56.

Simon, R. B., Stover, C. W., and Person, W. J., 1977, Earthquakes in the United States, January-March 1975: U.S. Geol. Survey Circ. 749-A, 35 p.

Sims, J. D., and Rymer, M. J., 1977, Study of modern lacustrine and glaciolacustrine sediments for earthquake-induced deformational structures, Kenai Peninsula, in Blean, K. M., ed., The United States Geological Survey in Alaska--Accomplishments during 1976: U.S. Geol. Survey Circ. 751-B, p. B46-B47.

Singer, D. A., Curtin, G. C., and Foster, H. L., 1976, Mineral resources map of the Tanacross quadrangle, Alaska: U.S. Geol. Survey Misc. Field Studies Map MF-767-E, 1 sheet, scale 1:250,000.

Singer, D. A., and Mackevett, E. M., Jr., 1977, Mineral resources map of the McCarthy quadrangle, Alaska: U.S. Geol. Survey Misc. Field Studies Map MF-773-C, 1 sheet, scale 1:250,000.

Skibitzke, H. E., 1977, Some aspects of remote sensing for consideration in planning environmental monitoring of the Aleyska Pipeline, Alaska: U.S. Geol. Survey Open-file Rept. $77-643,32$ p. and 9 sheets.

Slack, J. R., Smith, R. A., and Wyant, Timothy, 1977, An oilspill risk analysis for the western Gulf of Alaska (Kodiak Island) Outer Continental Shelf lease area: U.S. Geol. Survey Open-file Rept. $77-212,57 \mathrm{p}$.

Slack, K. V., Nauman, J. W., and Tilley, L. J., 1977, Benthic invertebrates in an arctic mountain stream, Brooks Range, Alaska: U.S. Geol. Survey Jour. Research, v. 5, no. 4, p. 519-527.

Sloan, C. E., 1977, Arctic hydrology studies, in Blean, K. M., ed., The United States Geological Survey in Alaska--Accomplishments during 1976: U.S. Geol. Survey Circ. 751-B, p. B30-B31.

Sloan, C. E., and Nauman, J. W., 1977, Investigations of impact on hydrologic features by construction and operation of TAPS, in Blean, K. M., ed., The United States Geological Survey in

Alaska--Accomplishments during 1976: U.S. Geol. Survey Circ. 751-B, p. B6.

Smith, J. G., 1977, Geology of the Ketchikan D-1 and Bradfield Canal A-1 quadrangles, southeastern Alaska: U.S. Geol. Survey Bull. 1425, 49 p.

Smith, J. G., Elliott, R. L., Berg, H. C., and Wiggins, B. D., 1977, Map showing general geology and location of chemically and radiometrically analyzed samples in parts of the Ketchikan, Bradfield Canal, and Prince Rupert quadrangles, southeastern Alaska: U.S. Geol. Survey Misc. Field Studies Map MF-825, 2 sheets, scale 1:250,000.

Staatz, M. H., 1977, I and $L$ vein system, Bokan Mountain, Prince of Wales Island, in Blean, K. M., ed., The United States Geological Survey in Alaska--Accomplishments during 1976: U.S. Geol. Survey Circ. 751-B, p. B74-B75.

Staatz, M. H., Conklin, N. M., and Brownfield, I. K., 1977, Rare earths, thorium, and other minor elements in sphene from some plutonic rocks in west-central Alaska: U.S. Geol. Survey Jour. Research, v. 5, no. 5, p. 623-628.

Stover, C. W., Simon, R. B., Person, W. J., and Minsch, J. H., 1977, Earthquakes in the United States, July-September 1975: U.S. Geol. Survey Circ. 749-C, p. C1-C29.

Tailleur, I. L., Ellersieck, I. F., and Mayfield, C. F., 1977a, Southwestern Brooks Range - Ambler River quadrangle AMRAP, in Blean, K. M., ed., The United States Geological Survey in Alaska--Accomplishments during 1976: U.S. Geol. Survey Circ. 751-B, p. B22-B24. 1977b, Mineral resources of the western Brooks Range, in Blean, K. M., ed., The United States Geological Survey in Alaska--Accomplishments during 1976: U.S. Geol. Survey Circ. 751-B, p. B24-B25.

Tailleur, I. L., Mayfield, C. F., and Ellersieck, I. F., 1977, Late Paleozoic sedimentary sequence, southwestern Brooks Range, in Blean, K. M., ed., The United States Geological Survey in Alaska--Accomplishments during 1976: U.S. Geol. Survey Circ. 751-B, p, B25-B27.

Tangborn, W. V., Mayo, L. R., Scully, D. R., and Krimme l, R. M., 1977, Combined ice and water balances of Maclure Glacier, California, South Cascade Glacier, Washington, and Wolverine and Gulkana Glaciers, Alaska, 1967 hydrologic year: U.S. Geol. Survey Prof. Paper 715-B, p. B1-B19.

Townshend, J. B., Papp, J. E., Moorman, M. J., Deadmon, C. E., and Tilton, S. P., 1976a, Preliminary geomagnetic data, College Observatory, Fairbanks, Alaska, November 1976: U.S. Geol. Survey Open-file Rept. 76-300-K, 20 p. (unnumbered).

1976b, Preliminary geomagnetic data, College Observatory, Fairbanks, Alaska, December 1976: U.S. Geol. Survey Open-file Rept. 76-300-L, 21 p. (unnumbered).

1977a, Preliminary geomagnetic data, College

Observatory, Fairbanks, Alaska, January 1977: U.S. Geol. Survey Open-file Rept. 77-300-A, 20 p. (unnumbered).

1977b, Preliminary geomagnetic data, College Observatory, Fairbanks, Alaska, February 1977: U.S. Geol. Survey Open-file Rept. 77-300-B, 19 p. 1977c, Preliminary geomagnetic data, College Observatory, Fairbanks, Alaska, March 1977: U.S. Geol. Survey Open-file Rept. $77-300-C, 20$ p. (unnumbered).

1977d, Preliminary geomagnetic data, College Observatory, Fairbanks, Alaska, April 1977: U.S. Geol. Survey Open-file Rept. 77-300-D, 20 p. (unnumbered).

Townshend, J. B., Papp, J. E., Moorman, M. J., and Tilton, S. P., 1977a, Preliminary geomagnetic data, College Observatory, Fairbanks, Alaska, May 1977: U.S. Geol. Survey Open-file Rept. 77-300-E, 18 p. (unnumbered).

$1977 b$, Preliminary geomagnetic data, College Observatory, Fairbanks, Alaska, June 1977: U.S. Geol. Survey Open-file Rept. 77-300-F, 18 p. (unnumbered).

1977c, Preliminary geomagnetic data, College Observatory, Fairbanks, Alaska, July 1977: U.S. Geol. Survey Open-file Rept. 77-300-G, 19 p. (unnumbered).

1977d, Preliminary geomagnetic data, College Observatory, Fairbanks, Alaska, August 1977: U.S. Geol. Survey Open-file Rept. 77-300-H, 20 p. (unnumbered).

1977e, Preliminary geomagnetic data, College Observatory, Fairbanks, Alaska, September 1977: U.S. Geol. Survey Open-file Rept. 77-300-I, 20 p. (unnumbered).

1977f, Preliminary geomagnetic data, College Observatory, Fairbanks, Alaska, October 1977: U.S. Geol. Survey Open-file Rept. 77-300-J, 20 p. (unnumbered).

Tysdal, R. G., and Case, J. E., 1977a, Placer River fault, Seward and Blying Sound quadrangles, in Blean, K. M., ed., The United States Geological Survey in Alaska--Accomplishments during 1976: U.S. Geol. Survey Circ. 751-B, p. B47-B48. 1977b, The McHugh Complex in the Seward 
quadrangle, south-central Alaska, in Blean, K. M., ed., The United States Geological Survey in Alaska--Accompli shments during 1976: U.S. Geol. Survey Circ. 751-B, p. B47-B49.

U.S. Geological Survey, 1976a, Geological Survey Research 1976: U.S. Geol. Survey Prof. Paper 1000, $414 \mathrm{p}$.

$1976 \mathrm{~b}$, Status of land in the McCarthy quadrangle, Alaska: U.S. Geol. Survey Misc. Field Studies Map MF-773-0, 1 sheet, scale 1:250,000.

1977a, Aeromagnetic map of the Ketchikan, Prince Rupert, and northeastern Craig quadrangles,

Alaska: U.S. Geol. Survey Open-file Rept. 77-359,

1 sheet, scale 1:250,000.

1977b, Aeromagnetic map of the Philip Smith Mountains quadrangle, Alaska: U.S. Geol. Survey Open-file Rept. 77-572, 1 sheet, scale 1:250,000.

1977c, Seismic engineering program report,

July-September 1976: U.S. Geol. Survey Circ.

736-C, 14 p.

1977d, Seismic engineering program report, October-December 1976: U.S. Geol. Survey Circ. 736-D, 23 p.

1977e, Seismic engineering program report, January-April 1977: U.S. Geol. Survey Circ. 762-A, $28 \mathrm{p}$.

1977f, Seismic engineering program report, May-August 1977: U.S. Geol. Survey Circ. 762-B, 26 p.

1977g, Water resources data for Alaska - water year 1975: Natl. Tech. Inf. Service PB-264 228/AS, $424 \mathrm{p}$.

U.S. Geological Survey, Topographic Division, 1977a, Bettles A-1 quadrangle, Alaska: U.S. Geol. Survey, Topog. Ser., scale 1:63,360.

$1977 \mathrm{~b}$, Bettles B-1 quadrangle, scale 1:63,360.

1977c, Bettles B-2 quadrangle, scale 1:63,360.

1977d, Bettles C-2 quadrangle, scale 1:63,360.

1977e, Bettles D-1 quadrangle, scale 1:63,360.

$1977 f$, Bettles D-2 quadrangle, scale 1:63,360.

1977g, Big Delta A-5 quadrangle, scale 1:63,360.

1977h, Big Delta C-6 quadrangle, scale 1:63,360.

1977i, Chandalar B-6 quadrangle, scale 1:63,360.

1977j, Chandalar C-6 quadrangle, scale 1:63,360.

1977k, Chandalar D-6 quadrangle, scale 1:63,360.

19771, Fairbanks C-1 quadrangle, scale 1:63,360.

$1977 \mathrm{~m}$, Fairbanks D-1 quadrangle, scale 1:63,360.

$1977 n$, Fairbanks D-2 quadrangle, scale 1:63,360.

1977o, Livengood B-3 quadrangle, scale 1:63,360.

$1977 \mathrm{p}$, Livengood $\mathrm{C}-4$ quadrangle, scale 1:63,360.

1977q, Livengood C-5 quadrangle, scale 1:63,360.

1977r, Livengood D-5 quadrangle, scale 1:63,360.

1977s, Philip Smith Mountains A-4 quadrangle, scale $1: 63,360$.

1977t, Philip Smith Mountains A-5 quadrangle, scale 1:63,360.

1977u, Philip Smith Mountains B-4 quadrangle, scale $1: 63,360$.

1977v, Philip Smith Mountains B-5 quadrangle, scale $1: 63,360$.

1977w, Philip Smith Mountains C-4 quadrangle, scale $1: 63,360$.

1977x, Philip Smith Mountains C-5 quadrangle, scale $1: 63,360$.

1977y, Philip Smith Mountains D-4 quadrangle, scale $1: 63,360$.

1977 , Sagavanirktok A-3 quadrangle, scale

$1: 63,360$.

19777aa, Sagavanirktok A-4 quadrangle, scale $1: 63,360$.

$1977 \mathrm{bb}$, Sagavanirktok B-3 quadrangle, scale $1: 63,360$.

1977cc, Sagavanirktok C-3 quadrangle, scale
$1: 63,360$.

1977dd, Sagavanirktok D-3 quadrangle, scale :63,360.

1977ee, Tanana D-1 quadrangle, scale 1:63,360.

$1977 \mathrm{ff}$, Wiseman A-1 quadrangle, scale 1:63,360. $1977 \mathrm{gg}$, Wiseman B-1 quadrangle, scale 1:63,360.

Vallier, T. L., and Gardner, J. V., 1977, Maps showing types and distribution of faults interpreted from seismic profiles in the St. George Basin region, southern Bering Sea: U.S. Geol. Survey Open-file Rept. $77-591,13 \mathrm{p}$. and 2 sheets.

Van Trump, George, Robinson, Keith, O'Leary, R. M., Day, G. W., and McDougal, C. M., 1977a, Magnetic tape containing results of spectrographic and chemical analyses of geochemical samples from the McCarthy quadrangle, Alaska: Natl. Tech. Inf. Service PB-266 902/AS, magnetic tape.

$1977 \mathrm{~b}$, Magnetic tape containing results of spectrographic and chemical analyses of geochemical samples from the McCarthy quadrangle, Alaska (User's guide): Natl. Tech. Inf. Service PB-266 903/AS, $20 \mathrm{p}$.

Vennum, W. R., and Eberlein, G. D., 1977, Spherulitic rhyolite dike from Goat Island, southeastern Alaska: U.S. Geol. Survey Jour. Research, v. 5, no. 4, p. 445-451.

Wallace, A. R., and Cady, J. W., 1977, Geophysical and petrologic studies of radioactive contact zones of pyroxenite dikes in nepheline syenite of the Ekiek Creek pluton, western Alaska, in Campbell, J. A., ed., Short papers of the U.S. Geological Survey uranium-thorium symposium, 1977: U.S. Geol. Survey Circ. 753 , p. 6-8.

Weber, F. R., Foster, H. L., and Keith, T. E. C., $1977 a$, A newly identified sequence of rocks in the Yukon-Tanana Upland, Alaska, in Blean, K. M., ed., The United States Geological Survey in Alaska--Accomplishments during 1976: U.S. Geol. Survey Circ. 751-B, p. B31-B32.

$1977 \mathrm{~b}$, Reconnaissance geologic map of the Big Delta A-2 and A-3 quadrangles, Alaska: U.S. Geol. Survey Misc. Field Studies Map MF-869, 1 sheet, scale $1: 63,360$.

Weber, F. R., and Turner, D. L., 1977, A late Tertiary thrust fault in the central Alaska Range, in Blean, K. M., ed., The United States Geological Survey in Alaska--Accomplishments during 1976: U.S. Geol. Survey Circ. 751-B, p. B66-B67.

Whitmore, F. C., Jr., and Gard, L. M., Jr., 1977, Steller's sea cow (Hydrodamalis gigas) of late Pleistocene age from Amchitka, Aleutian Islands, Alaska: U.S. Geol. Survey Prof. Paper 1036, 19 p.

Williams, J. R., Yeend, W. E., Carter, L. D., and Hamilton, T. D., 1977, Preliminary surficial deposits map of National Petroleum Reserve Alaska: U.S. Geol. Survey Open-file Rept. 77-868, 2 sheets, scale 1:500,000.

Wilson, F. H., 1977, Some plutonic rocks of southwestern Alaska, a data compilation, 1977: U.S. Geol. Survey Open-file Rept. 77-501, 9 p. and 4 sheets.

Winkler, G. R., MacKevett, E. M., Jr., and Nelson, S. W., 1977, Strata-bound iron-copper-zinc deposits, Prince William Sound region, southern Alaska, in Blean, K. M., ed., The United States Geological Survey in Alaska: accomplishments during 1976: U.S. Geol. Survey Circ. 751-B, p. B44-B45.

Winkler, G. R., and Tysdal, R. G., 1977, Conglomerate in flysch of the Orca Group, Prince William Sound, southern Alaska, in Blean, K. M., ed., The United States Geological Survey in Alaska--Accompli shments during 1976: U.S. Geol. Survey Circ. 751-B, p. B43-B44. 
Yeend, W. E., 1977, Tertiary and Quaternary deposits of The Palisades, central Alaska: U.S. Geol. Survey Jour. Research, v. 5, no. 60, p. 747-752.

Yehle, L. A., 1977a, Reconnaissance engineering geology and geologic hazards of the Metlakatla area, Annette Island, in Blean, K. M., ed., The United States Geological Survey in

Alaska--Accomplishments during 1976: U.S. Geol. Survey Circ. 751-B, p. B72.

$1977 b$, Reconnaissance engineering geology of the Metlakatla area, Annette Island, Alaska, with emphasis on evaluation of earthquakes and other geologic hazards: U.S. Geol. Survey Open-file Rept. 77-272, $93 \mathrm{p}$.

Zenone, Chester, 1977, Urban hydrology studies in the Anchorage area, in Blean, K. M., ed., The United States Geological Survey in

Alaska--Accomplishments during 1976: U.S. Geol. Survey Circ. 751-B, p. B52.
REVISIONS TO 1:1,000,000-SCALE MAP OF ALASKA

INTRODUCTION

Geologic mapping in Alaska is an ongoing process, each field season yielding new information and insights. Office compilation of new data permits periodic updating of parts of the $1: 1,000,000$-scale published map of the State (Beikman, 1974a, 1974b, 1975a, 1975b; Beikman and Lathram, 1976). Included in this chapter are updated maps for two areas of the State; the Goodnews and Hagemeister Island quadrangles and the Ketchikan and Prince Rupert quadrangles. These maps are discussed in papers in "Summary of Important Results." It is hoped that this format will allow interested parties to keep their 1:1,000,000-scale maps as current as possible, as it will be some time before a complete revision can be made.

\section{REFERENCES CITED}

Beikman, H. M., 1974a, Preliminary geologic map of the southwest quadrant of Alaska: U.S. Geol. Survey Misc. Field Studies Map MF-611, 2 sheets, scale 1:1,000,000.

- 1974b, Preliminary geologic map of the southeast quadrant of Alaska: U.S. Geol. Survey Misc. Field Studies Map MF-612, 2 sheets, scale 1:1,000,000.

1975a, Preliminary geologic map of southeastern Alaska: U.S. Geol. Survey Misc. Field Studies Map MF673,2 sheets, scale 1:1,000,000.

1975b, Preliminary geologic map of the Alaska Peninsula and the Aleutian Islands: U.S. Geol. Survey Misc. Field Studies Map MF-674, 2 sheets, scale 1:1,000,000.

Beikman, H. M., and Lathram, E. H., 1976, Preliminary geologic map of northern Alaska: U.S. Geol. Survey Misc. Field Studies Map MF-789, 2 sheets, scale 1:1,000,000. 


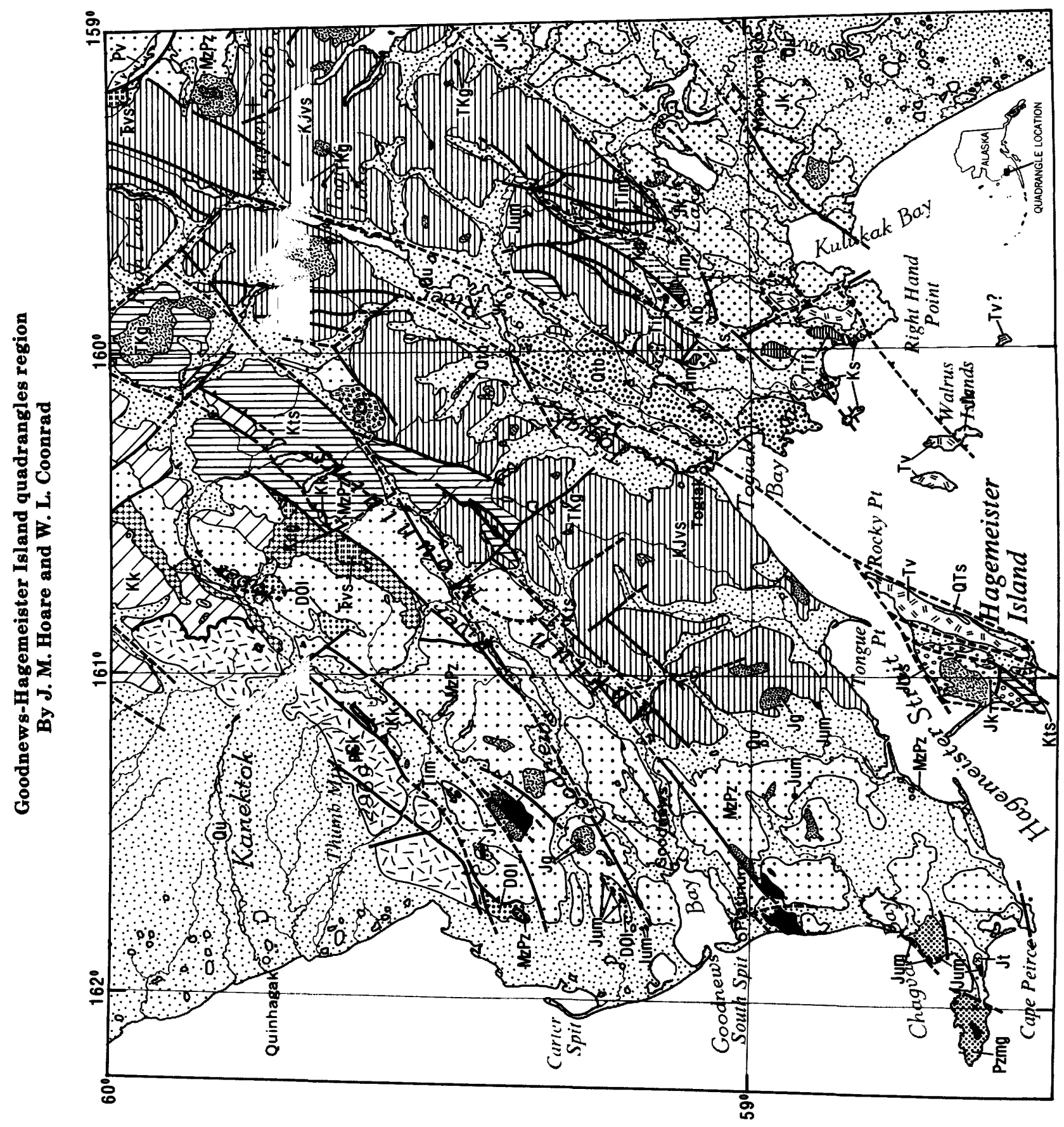




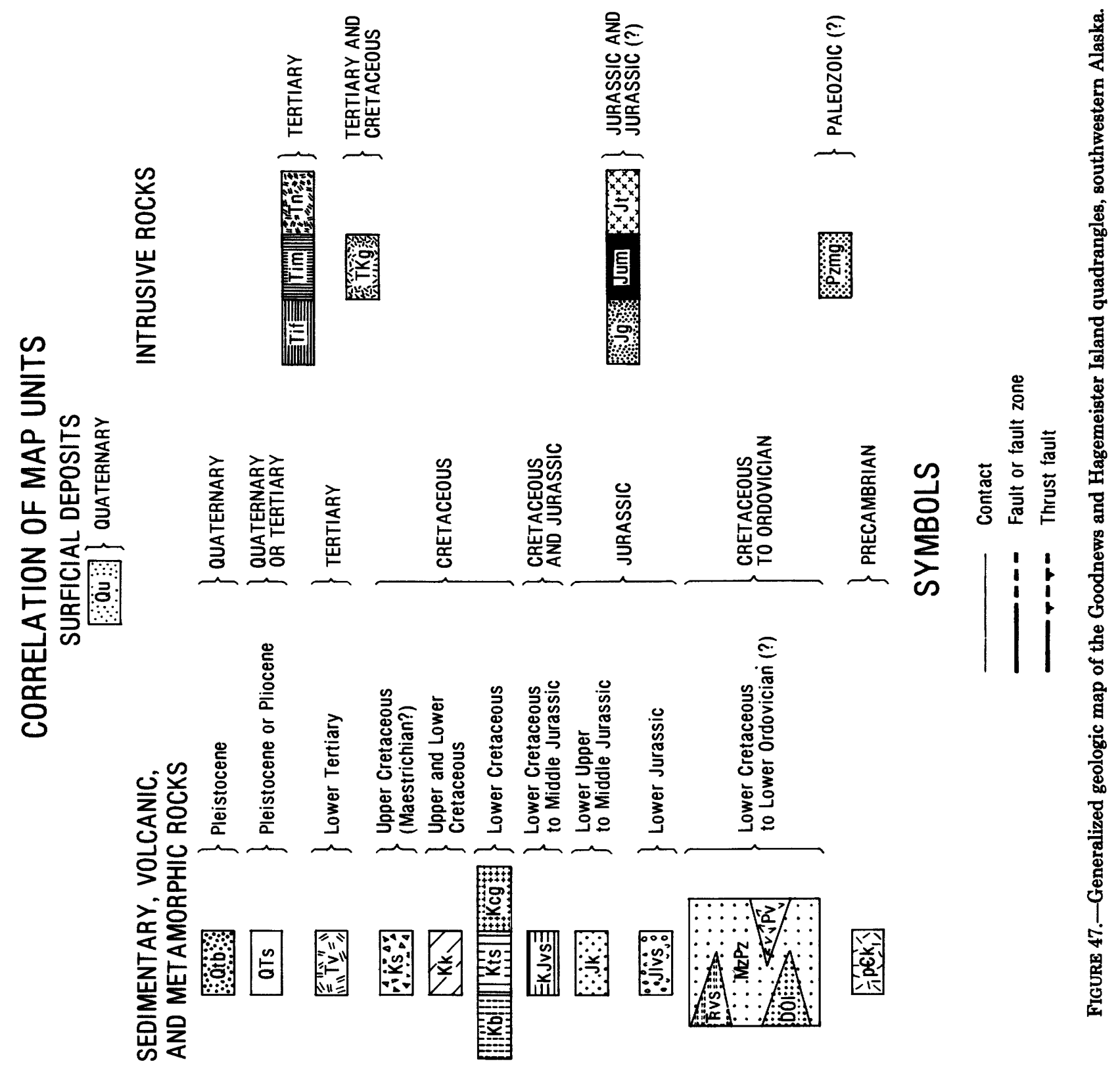


Ketchikan and Prince Rupert quadrangles

By H. C. Berg, R. L. Elliott, J. G. Smith, and R. D. Koch

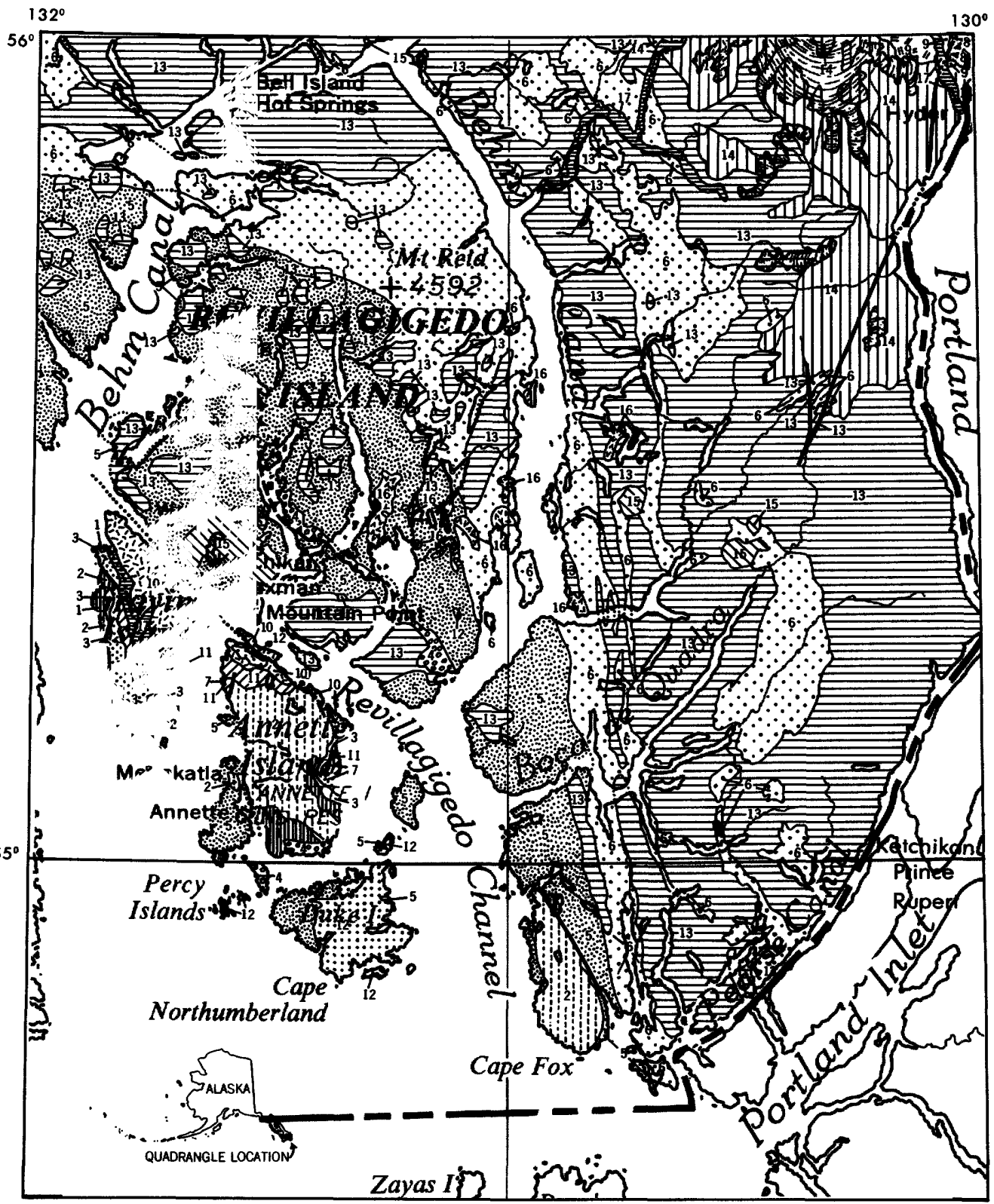

FIGURE 48.-Generalized geologic map of Ketchikan and Prince Rupert quadrangles, southeastern Alaska. Scale 1:1,000,000 or 1 inch equals approximately $26 \mathrm{~km}$. Base map from National Atlas of the United States, U.S. Geological Survey, 1970. 


\section{CORRELATION OF MAP UNITS}

\begin{tabular}{|c|c|c|c|}
\hline 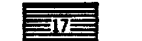 & & & QUATERNARY \\
\hline 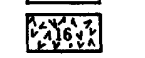 & & & $\begin{array}{l}\text { QUATERNARY } \\
\text { AND TERTIARY }\end{array}$ \\
\hline 15 & Miocene & & \\
\hline Ш & Eocene & & TERTIARY \\
\hline ह13 & & & $\begin{array}{l}\text { TERTIARY OR } \\
\text { CRETACEOUS }\end{array}$ \\
\hline 居: & & & \\
\hline 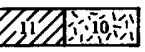 & Middle Jurassic & & JURASSIC \\
\hline 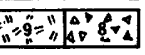 & & & $\begin{array}{l}\text { JURASSIC OR } \\
\text { TRIASSIC }\end{array}$ \\
\hline 3 & Upper Triassic & & TRIASSIC \\
\hline$\because 6 \because 55$ & & & $\begin{array}{l}\text { MESOZOIC OR } \\
\text { PALEOZOIC }\end{array}$ \\
\hline 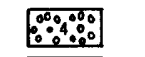 & & $\begin{array}{l}\text { Middle and } \\
\text { upper Paleozoic }\end{array}$ & \\
\hline 3 & & & \\
\hline in: & & & OR OLDER \\
\hline in|W| & & Silurian & \\
\hline
\end{tabular}

DESCRIPTION OF MAP UNITS

EN17 UNCONSOLIDATED DEPOSITS, UNDIVIDED (Quaternary)

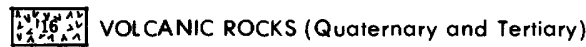

PLUTONIC ROCKS, UNDIVIDED (Miocene)

W14] PLUTONIC ROCKS, UNDIVIDED (EOCene)

13- PLUTONIC ROCKS, UNDIVIDED (Tertiary or Cretaceous)

GRAVINA ISLAND FORMATION AND UNNAMED CORRELATIVE ROCKS (Upper or Middle Jurassic)

$\because: 13::$ Ultramafic and other plutonic rocks

Di17 Metasedimentary rocks

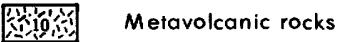

TEXAS CREEK GRANODIORITE (Jurassic or Triassic)

A.

Me (Jurassic or Triassic)

7 METAMORPHOSED SEDIMENTARY AND VOLCANIC ROCKS

$\because 7 \therefore$ (Upper Triassic)

$\because 6 \because$ PARAGNEISS AND AMPHIBOLITE (Mesozoic or Paleozoic)

5\% METAMORPHIC ROCKS, UNDIVIDED (Mesozoic or PaleozoIC)

$\because \because \because \circ$ METAMORPHOSED SEDIMENTARY AND MINOR

$0 \% 4: 0$ VOLCANIC ROCKS (Middle and upper Paleozoic)

3 FELSIC METAVOLCANIC ROCKS (Paleozoic or older)

PLUTONIC ROCKS, CHIEFLY TRONDHJEMITE (Silurion or older)

||||||| METAMORPHOSED SEDIMENTARY AND VOLCANIC ROCKS

(Silurian or older)

\section{SYMBOLS}

Contact. Approximately located; dotted where concealed

High-angle fault. Dashed where inferred;

dotted where concealed

Thrust fault. Dashed where concealed. Sawteeth on upper plate

Figure 48.-Continued. 